UNIVERSIDADE DE SÃO PAULO

FACULDADE DE EDUCAÇÃO

ISANEIDE DOMINGUES

O COORDENADOR PEDAGÓGICO E O DESAFIO

DA FORMAÇÃO CONTÍNUA DO DOCENTE NA ESCOLA

SÃO PAULO

2009 
ISANEIDE DOMINGUES

\title{
O COORDENADOR PEDAGÓGICO E O DESAFIO DA FORMAÇÃO CONTÍNUA DO DOCENTE NA ESCOLA
}

\author{
Tese apresentada à Faculdade de Educação da \\ Universidade de São Paulo como parte dos requisitos \\ para a obtenção do título de Doutor em Educação. \\ Área de concentração: Didática, teorias de ensino e \\ práticas escolares. \\ Orientadora: \\ Prof $^{a}$. Dr ${ }^{\mathrm{a}}$. Maria Isabel de Almeida.
}

\section{UNIVERSIDADE DE SÃO PAULO}

\section{São Paulo}


AUTORIZO A REPRODUÇÃO E DIVULGAÇÃO TOTAL E PARCIAL DESTE TRABALHO, POR QUALQUER MEIO CONVENCIONAL OU ELETRÔNICO, PARA FINS DE ESTUDO E PESQUISA, DESDE QUE CITADA A FONTE.

Catalogação na Publicação

Serviço de Biblioteca e Documentação

Faculdade de Educação da Universidade de São Paulo

371.197 Domingues, Isaneide

D671c O coordenador pedagógico e o desafio da formação contínua do docente na escola / Isaneide Domingues; orientação Maria Isabel de Almeida. São Paulo: s.n., 2009.

$235 \mathrm{p}$.

Tese (Doutorado - Programa de Pós-Graduação em Educação. Área de Concentração: Didática, Teoria de Ensino e Práticas Escolares) - Faculdade de Educação da Universidade de São Paulo.

1. Coordenação escolar 2. Coordenadores escolares 3. Cultura escolar 4. Formação continuada do professor I. Almeida, Maria Isabel de, orient. 


\section{FOLHA DE APROVAÇÃO}

Isaneide Domingues

O coordenador pedagógico e o desafio da formação contínua do docente na escola

Tese apresentada à Faculdade de Educação da Universidade de São Paulo como parte dos requisitos para a obtenção do título de Doutor em Educação.

Área de concentração: Didática, teorias de ensino e práticas escolares.

Orientadora:

Prof $^{a}$. Dra ${ }^{a}$. Maria Isabel de Almeida.

Aprovado em:

de de 2009.

Banca Examinadora

Prof. Dr.

Instituição: Assinatura

Prof. Dr.

Instituição: Assinatura

Prof. Dr.

Instituição: Assinatura

Prof. Dr.

Instituição: Assinatura

Prof. Dr.

Instituição: Assinatura 
Aos meus pais Apparecido Domingues (sempre presente) e Maria Digna dos Santos Domingues, por acreditarem nos meus projetos e me apoiarem incondicionalmente.

Às coordenadoras participantes deste trabalho de pesquisa, que acolheram os meus questionamentos e deixaram aproximá-los de suas práticas.

Ao Hélio. 


\section{AGRADECIMENTOS}

Um trabalho de pesquisa não é uma construção individual, mas um esforço de congregar contribuições diversas. Agradeço a todos que, de uma forma ou de outra, contribuíram para a elaboração deste trabalho. Expresso aqui meu carinho e gratidão.

A Deus que me possibilitou chegar até aqui e colocou na minha vida pessoas queridas para me ajudar.

À Prof ${ }^{a}$ Dra. Maria Isabel de Almeida, minha orientadora e amiga, por quem tenho estima e admiração, que, durante esses anos de convivência, acolheu minhas ideias, apoiou minhas iniciativas, acompanhou minha formação como pesquisadora e me presenteou com sua orientação firme, mas respeitosa. Muito obrigada.

Especialmente, às coordenadoras pedagógicas e aos professores que participaram desta pesquisa, que, acreditando poder contribuir para a reflexão sobre o papel do coordenador na formação contínua do docente na escola, tornaram suas as minhas questões e de forma generosa complementaram este trabalho. Espero que todos se sintam contemplados e homenageados nas falas aqui expostas.

Aos professores do Programa de Pós-Graduação em Educação da Faculdade de Educação da Universidade de São Paulo.

Aos professores doutores Maria Amélia Santoro Franco e José Cerchi Fusari, pela colaboração preciosa no momento da qualificação.

Aos meus pais Maria Digna e Apparecido (in memorian), aos meus irmãos Isael e Isabel, aos meus cunhados, Claudia e Mário, aos meus sobrinhos, Matheus e Vinicius e a tia Toninha pelo apoio de sempre.

Ao Hélio pela leitura crítica do texto original, pelas sugestões valiosas, pelo incentivo, pela paciência nos momentos de tensão e por fazer parte da minha vida, tornando-a ainda melhor.

À Da. Rosa e à Loide por me acolherem em suas orações.

À Vanda e à Elisabete, pela leitura crítica e pelas considerações pertinentes, principalmente, pela disposição em me ajudar e pela amizade. Muito obrigada 
À Verbena Moreira S. S. Lisita (in memorian), pelas contribuições oferecidas após a leitura do relatório de qualificação, pelo carinho com que acolhia minhas dúvidas e solicitações.

Aos amigos do Grupo de Estudo e Pesquisa da Faculdade de Educação - GEPEFE: Alexandre de Paula Franco, Amanda C. T. Lopes Marques, Andrés Evaristo Reyes Pincheiro, Elisabete Ferreira Esteves Campos, Evandro Ghedin, José Cerchi Fusari, Kalline Silene da Silva, Lenilda R. Albuquerque de Faria, Maria Amélia do Rosário S. Franco, Marineide de Oliveira Gomes, Noeli Prestes Padilha Rivas, Nora Faundez-Vallejos, Pérsio Nakamoto, Rosa Maria de Freitas Rogério, Selma Garrido Pimenta, Silas Borges Monteiro, Terezinha Azeredo Rios, Uirá Fernandes, Umberto de Andrade Pinto, Valéria C. Fernandes Belletati, Vanda Moreira Machado, Yoshie Ussami Ferrari Leite e Wanderson Ferreira Alves, pela interlocução diligente, que me possibilitou avançar nas minhas análises, e pela acolhida respeitosa às minhas dúvidas.

Aos companheiros da "EMEI do CEU Vila Curuçá", que me acolheram como coordenadora e acompanharam meus progressos nos últimos anos; em especial, ao Valter e à Silmara, pela amizade, apoio e interlocução.

Ao Pérsio Nakamoto, pela amizade oferecida, assim que entrei na FEUSP, por ter me acompanhado todos esses anos com inúmeras contribuições, por suas sugestões para este texto.

À Márcia Celestini Vaz, que assumiu a tarefa de revisão deste trabalho, fazendo-a com presteza e rigorosidade. Obrigada pelas muitas contribuições neste processo.

Às amigas Maria de Fátima Oliveira, Vilma Dourado, Maria Helena Fernandes da Cunha e Ivonete Pereira Guedes, companheiras na luta pela educação, pela amizade sincera que perdoa o afastamento.

A todos, os meus agradecimentos por fazerem parte da minha história de vida e, desta forma, contribuirem para que eu escrevesse mais uma parte dela. 
Não abandone a sabedoria e ela o protegerá; ame-a, e ela cuidará de você. $O$ conselho da sabedoria é: procure obter sabedoria; use tudo o que você possui para adquirir entendimento.

(Provérbios de Salomão, Capítulo 4, versos 6 e 7)

O temor do senhor é o princípio do conhecimento [...] (Provérbios de Salomão, Capítulo 1, verso 7) 


\section{RESUMO}

DOMINGUES, Isaneide. O coordenador pedagógico e o desafio da formação contínua do docente na escola. São Paulo, 2009. Tese de Doutorado.

Faculdade de Educação da Universidade de São Paulo

O discurso da formação contínua do docente centrada na escola tem sido incorporado pelas políticas públicas de formação, que têm transferido para a escola boa parte da responsabilidade pelo desenvolvimento profissional do professor. O coordenador pedagógico, na Rede Municipal de Ensino de São Paulo, é o profissional responsável pelo acompanhamento e desenvolvimento de tal processo centrado na escola. Esta pesquisa toma como objeto de investigação o papel do coordenador pedagógico como gestor dos tempos/espaços de formação contínua do docente na escola e apresenta como objetivo investigar como esse profissional organiza e implementa a formação contínua desenvolvida no horário coletivo, considerando a relativa autonomia da escola e seus próprios saberes sobre a articulação da formação no espaço escolar. A pesquisa empírica, de base qualitativa, envolveu quatro coordenadoras pedagógicas, duas escolas e dois grupos de professores durante o cumprimento da Jornada Especial Integral de Formação (JEIF). As entrevistas semiestruturadas feitas com as coordenadoras pedagógicas possibilitaram considerar o ponto de vista dessas profissionais sobre o ser e o estar na coordenação. $\mathrm{O}$ acompanhamento dos projetos de formação desenvolvidos na JEIF revelou a influência de aspectos relativos à cultura escolar e aos projetos de governo que interferem nessa ação, que deixa de ser uma opção coletiva dos docentes e passa a ser uma determinação da política educacional. O grupo dialogal organizado por meio de uma 'bricolage' metodológica procurou ouvir os professores participantes desse processo formativo e suas percepções sobre esse espaço de ação-reflexão e de atuação do coordenador pedagógico. Os resultados confirmaram a tese de que o trabalho do coordenador pedagógico, de acordo com o foco proposto nesta pesquisa, é um 'saberfazer' multideterminado, decorrente de fatores como o desenvolvimento pessoal, a organização institucional e as políticas públicas. Também apontaram que, apesar da fragilidade da formação inicial do coordenador e da formação contínua oferecida, caracterizase por uma natureza instrucional e pela mobilização dos coordenadores por meio de processos de socialização profissional, principalmente no início na profissão, o que tem contribuído para ampliar sua competência formativa. A coordenação pedagógica, quando considera a escola como locus desse processo, assentada na concepção do protagonismo dos professores e da autonomia desse estabelecimento, investe nos saberes docentes e insiste nos projetos elaborados coletivamente, optando pelo enfrentamento da cultura imposta pelo sistema por meio das reformas. Contudo, compreendem esse modelo de formação como influenciado pelas contradições e por resistências em maior ou menor grau. As coordenadoras pedagógicas consideram-se responsáveis pela formação na escola, assumindo o discurso desse espaço como locus de sua ação. Todavia, precisam empregar tempo na construção de uma identidade formativa que possibilite legitimar, junto às equipes escolares e ao sistema, uma liderança pautada na adequação do tempo às tarefas da coordenação, na compreensão do papel do coordenador pedagógico, não como técnico, mas como sujeito aprendente do seu fazer numa perspectiva reflexiva e crítica e na formação como introdeterminada pelos docentes também responsáveis pela sua elaboração, implementação e avaliação.

PALAVRAS-CHAVE: 1. Formação Contínua; 2. Gestão da Escola; 3. Coordenação Pedagógica; 4. Protagonismo Docente; 5. Cultura Escolar 


\begin{abstract}
DOMINGUES, Isaneide. The pedagogical coordinator and the challenge of pedagogical formations of teachers in school. São Paulo, 2009, p. Doctore Thesis
\end{abstract}

Faculdade de Educação da Universidade de São Paulo

The speech of continuing formation of teachers focused on school has been built by public policies of formation, which have transferred to school much of the responsibility for the professional development of teachers. The pedagogical coordinator at the Rede Municipal de Ensino de São Paulo is responsible for monitoring and professional development of this process focused on school. This research takes as its object of research the role of the pedagogical coordinator as manager of the times/spaces of continuous formatiom of teachers in schools and aims to investigate how this professional organizes and implements the continuing formation developed in the collective time, considering the relative autonomy of the school and their own knowledge about the articulation of formation in school. The qualitative base empirical research involved four pedagogical coordinators, two schools and two groups of teachers during the meetings of Jornada Especial Integral de Formação (JEIF). Semi-structured interviews with the coordinators made it possible to consider their pedagogical point of view about being in coordination. The monitoring of the formation projects developed in JEIF showed the influence of school culture aspects and of government projects interfering in that action, which ceases to be a collective choice of teachers and becomes a determination of educational policy. The dialogue group organized by a 'DIY' method tried to listen to the teachers of that formation process and their perceptions about the space for action-reflection and action of the pedagogical coordinator. According to the focus proposed in this research, the results confirmed the thesis that the work of the coordinator is a multi-determined 'know-how' due to personal formation, institutional organization and public policies. It also showed that despite the fragility of the initial formation of the coordinator and the offered continuing formation characterized by an instructional nature, mobilization of the coordinators through professional socialization processes, especially early in the profession, has helped to expand its formative competence. The pedagogical coordination, when considering the school as locus of this process, based on the protagonism conception of teachers and the school autonomy, invest in teacher knowledge and insists on the collectively developed projects, opting for culture confrontation imposed by the system through reforms. However it sees this type of formation as influenced by contradictions and by resistance to a greater or lesser degree. The pedagogical coordinators consider themselves responsible for formation in school, assuming the speech that considers that space as locus of formation. However, time should be spent in building a formative identity that allows legitimate, with the school teams and the system, a leadership based on the suitability of time to the task of coordination, understanding the pedagogical coordinator role, not as a technician, but as a learning subject of his doing in a reflective and critical perspective and in formation as determined from the inside out by the subjects responsible for their development, implementation and evaluation.

KEYWORDS: 1. Continuing formation; 2. Managing of the school; 3. Pedagogical Coordination; 4. Teachers' protagonism; 5. School culture. 


\section{LISTAS DE QUADROS}

Quadros:

Págs.

Quadro 01 - Salas e turmas da Escola A 46

Quadro 02 - Projetos de formação na escola A e os grupos de professores participantes 47

Quadro 03 - Salas e turmas da Escola B

Quadro 04 - Projetos de formação na escola B e os grupos de professores participantes

Quadro 05 - Complexidade da formação do coordenador pedagógico 87

Quadro 06 -.A formação do CP, um entrecruzamento de experiências 88

Quadro 07 - O projeto político pedagógico (PPP) como referência para a formação centrada na escola

Quadro 08 - Aspectos constitutivos da formação centrada na escola 130

Quadro 09 - O Projeto Especial de Ação (PEA) - proposta de formação na escola

Quadro 10 - Configurações do trabalho com o PEA na percepção dos participantes da pesquisa 140

Quadro 11- Pauta da ação formativa 160

Quadro 12- O PEA na visão dos professores. 


\section{LISTA DE ABREVIATURAS E SIGLAS}

\begin{tabular}{|c|c|}
\hline AP & Assistente Pedagógico \\
\hline CEI & Centro Educacional Infantil \\
\hline CME & Conselho Municipal de Educação \\
\hline $\mathrm{CP}$ & Coordenador Pedagógico \\
\hline CONAE & Coordenadoria dos Núcleos de Ação Educativa \\
\hline DOT & Diretoria de Orientação Técnica \\
\hline $\mathrm{DP}$ & Divisão Pedagógica \\
\hline EEEF & Escola Estadual de Ensino Fundamental \\
\hline EJA & Educação de Jovens e Adultos \\
\hline EMEF & Escola Municipal de Ensino Fundamental \\
\hline EMEI & Escola Municipal de Educação Infantil \\
\hline EMEFM & Escola Municipal de Ensino Fundamental e Médio \\
\hline FAE & Faculdade de Administração e Economia \\
\hline FAFE & Fundação de Apóio à Faculdade de Educação \\
\hline FEUSP & Faculdade de Educação da Universidade de São Paulo \\
\hline HTPC & Hora de Trabalho Pedagógico Coletivo \\
\hline GAAE & Grupo de Acompanhamento da Ação Educativa \\
\hline $\mathrm{JB}$ & Jornada Básica \\
\hline JEA & Jornada Especial Ampliada \\
\hline JEI & Jornada Especial Integral \\
\hline JEIF & Jornada Especial Integral de Formação \\
\hline JTI & Jornada de tempo Integral \\
\hline LDB & Lei de Diretrizes e Base da Educação Nacional \\
\hline PEA & Projeto Estratégico de Ação \\
\hline PEA & Projeto Especial de Ação \\
\hline PIC & Projeto Intensivo do Ciclo I \\
\hline PCP & Professor Coordenador Pedagógico \\
\hline PPP & Projeto Político Pedagógico \\
\hline PSP & Partido Social Progressista \\
\hline PT & Partido dos Trabalhadores \\
\hline PUC-SP & Pontifícia Universidade Católica de São Paulo \\
\hline SAP & Sala de Apoio Pedagógico \\
\hline SME & Secretaria Municipal de Educação \\
\hline SMESP & Secretaria Municipal de Educação de São Paulo \\
\hline SOP & Serviço de Orientação Pedagógica \\
\hline STE & Prestador de Serviço Técnico Educacional \\
\hline TOF & Toda força no primeiro ano \\
\hline
\end{tabular}


SUMÁRIO

INTRODUÇ̃̃O

CAPÍTULO I - A PESQUISA E SEU DESENVOLVIMENTO.

- A construção metodológica - o objeto e o contexto da pesquisa

2. As parceiras da pesquisa e as escolas que a sediaram

2.1 Coordenadora Maria Vitória - a formação como um processo de socialização dos conhecimentos docentes

2.2 Escola A e a formação contínua coordenada por Maria Vitória

2.3 Coordenadora Maria Stella - pensando a formação como tarefa essencial.

2.4 Coordenadora Maria Leda - pensando a formação para a mudança profissional........

2.5 Escola B e a formação contínua coordenada por Maria Leda.

2.6 Coordenadora Maria Augusta - pensando a formação numa perspectiva libertadora.

3 Alguns nexos entre entrevista, observação e grupo dialogal

CAPÍtulo II - A COORDENAÇÃo PEDAGóGICA, UMA TRAJETória PROFISSIONAL EM CONSTRUÇÃO

1. O início da trajetória da coordenação pedagógica.

2. A coordenação pedagógica na Rede Municipal de Ensino de São Paulo ................. 66

3. A pedagogia e a formação inicial do coordenador pedagógico .................................. 76

4. A formação contínua do coordenador: um emaranhado complexo de 84 experiências

5. O período de iniciação profissional do coordenador pedagógico: um terreno 98 fértil para a autoformação

5.1 A insegurança, o medo e o processo de se constituir coordenador

5.2 O choque com a realidade complexa da escola

5.3 O processo de aprender normas, valores e condutas - a cultura da escola 
1. A formação contínua centrada na escola

2. O projeto político pedagógico como expressão da relativa autonomia, vontade e necessidade formativa das equipes escolares

3. O PEA, configuração (ou não?) das decisões coletivas

4. O trabalho de formação compartilhado - o diretor e o supervisor como parceiros do trabalho do coordenador na formação na escola

4.1. O diretor, componente da equipe pedagógica

CAPÍtUlo IV - O COORDENADOR PEDAGóGICO E A FORMAÇÃo DO DOCENTE NA ESCOLA

1. O coordenador pedagógico como gestor da formação

1.1. Primeiro desafio: o descompasso entre as instâncias do trabalho do coordenador e os dispositivos formativos

165

1.2. Segundo desafio: a formação como um processo introdeterminado

1.3. Terceiro desafio: fazer a articulação entre as necessidades da formação, a cultura escolar e as determinações das políticas públicas

2 - Aspectos relevantes e intervenientes da formação contínua centrada na escola na visão dos professores

REFERÊNCIAS BIBLIOGRÁFICAS

ANEXO A Cópia do Boletim do SIMPEEM.

ANEXO B Entrevista semi-estruturada..

ANEXO C Quadro síntese das observações nas escolas. 
Minha atuação no desenvolvimento de um trabalho de formação com os professores levou-me a procurar na pesquisa uma melhor compreensão dos aspectos relativos à formação contínua processada na escola. Foi nessa época que busquei o ingresso no curso de pósgraduação em Educação - mestrado da Faculdade de Educação da Universidade de São Paulo. O mestrado mostrou-me caminhos metodológicos e epistemológicos que me permitiram refletir, especificamente, sobre as possibilidades formativas da jornada que oportunizava a participação no horário coletivo de trabalho pedagógico.

Essa experiência marcou sensivelmente minha formação como pesquisadora, principalmente porque, para além da investigação desenvolvida, naquele momento, o contexto contava uma história de profissionalidade do coordenador pedagógico e de uma compreensão das influências sobrevindas ao espaço formador, na época, a Jornada Especial Integral (JEI).

Exercer a coordenação pedagógica como atividade profissional ${ }^{1}$, na Rede Municipal de Ensino de São Paulo, após ter vivenciado treze anos de trabalho docente na escola pública, possibilitou-me experienciar a complexidade das tarefas da coordenação pedagógica, especialmente a formação contínua do professor. Durante esses vinte e quatro anos de trabalho na escola pública, pude acompanhar as mudanças no sistema de ensino, decorrentes das transformações da sociedade e das determinações de órgãos internacionais que regulam a educação nos países em desenvolvimento, e observar a influência dessa história na ação de

1 Ao tratarmos o coordenador pedagógico como profissional, não o estamos fazendo a partir de critérios adotados pela sociologia das profissões. Usaremos o termo para caracterizar aquele que exerce uma ocupação/trabalho (um modo de ser), seja por praticá-la/o sistematicamente, seja por obter recursos necessários para sua subsistência. Freidson (1998 apud Guimarães, 2006) traz uma definição que encerra o sentido que queremos dar neste trabalho. Segundo o autor, "Profissional é aquele que realiza um trabalho, tendo 
coordenar o trabalho pedagógico na escola, principalmente a promoção do desenvolvimento profissional docente. Consequentemente, esta pesquisa parte de pressupostos ligados às questões da minha atuação como coordenadora pedagógica na rede municipal de São Paulo. Segundo Woods (1996, p. 11):

As realidades pessoais podem ser de primordial importância, tanto para a escolha e orientação da investigação, como para o investigador. Fazemos, freqüentemente, investigação para descobrirmos mais sobre nós próprios. Isto não significa que sejamos indulgentes, mas sim que é essencialmente através do self que compreendemos o mundo. Por sua vez, as descobertas que fazemos se refletem no self, que afeta a investigação, e assim sucessivamente.

Na coordenação venho realizando um trabalho de formação contínua de professores no horário coletivo de trabalho pedagógico proporcionado pela Jornada Especial Integral $\left(\mathrm{JEI}^{2}\right)$, atualmente denominada de Jornada Especial Integral de Formação (JEIF). Trata-se de uma proposta de formação desenvolvida na escola, de caráter teórico-prático, tendo como estratégia a reflexão crítica sobre a ação, objetivando a construção de um ofício autônomo e eficiente em relação à atividade de ensinar.

Para desenvolver a coordenação pedagógica na escola pública, a experiência como professora no ensino fundamental, envolvida em processos múltiplos de formação contínua dentro e fora da escola, tornou-se essencial. De fato, quando ingressei em 1996, para atuar no cargo de coordenadora pedagógica, levava na bagagem minha história pessoal e profissional e a esperança de promover mudanças na instituição. O que me ajudou nessa empreitada e serviu-me de 'modelo' foi a participação nos grupos de formação da prefeitura na gestão do Partido dos Trabalhadores de 1989 a 1992.

conhecimento a respeito; e o faz em atendimento a uma necessidade da sociedade, em relação à remuneração, visando à produção individual e coletiva da existência humana" (p.5)

A JEI corresponde a uma das jornadas de opção dos professores da Rede Municipal de Ensino de São Paulo. Nesse espaço, são desenvolvidos os horários coletivos, que acabam por se tornarem sinônimo dessa jornada e compreendem ações coletivas desenvolvidas por meio de projetos elaborados pelas próprias escolas com vistas à melhoria do processo ensino-aprendizagem. Ao todo, eram três jornadas de opção: JEI (Jornada Especial Integral) - 40 horas-aulas semanais que se distribuem em 25 horas-aula desenvolvidas em sala; 11 horas-aula de horário coletivo com os demais membros da equipe escolar; e 4 horas-aula desenvolvidas em local de livre escolha; JEA (Jornada Especial Ampliada), que corresponde a 30 horas-aula semanais, sendo 25 horasaula desenvolvidas em sala de aula; 3 horas-atividade, preferencialmente com o coletivo da escola; 2 horas-aula em lugar de livre escolha; e JB (Jornada Básica), que corresponde a 20 horas-aula semanais, sendo 18 horasaula desenvolvidas na sala de aula; 1 hora-atividade na escola; e 1 hora- atividade em local de livre escolha. Quando a pesquisa foi iniciada, a JEI que era o nome da jornada que possibilitava um tempo maior para o horário coletivo, surgiu em 1992 com a criação do Estatuto do Magistério Público Municipal, Lei no 11.229/92, com a finalidade, grosso modo, de promover um tempo maior para a reflexão docente sobre as questões didáticopedagógicas. Em 2007, o Estatuto é alterado pela Lei nº 14.660/07. 
Em 2002, fui convidada para trabalhar na Coordenadoria de Educação ${ }^{3}$ de São Miguel como $\mathrm{STE}^{4}$. Com isso, pude experienciar, de diversas perspectivas, situações relacionadas direta ou indiretamente à atividade de formação desenvolvida pelo coordenador pedagógico na escola. Uma das facetas desse trabalho foi o acompanhamento da própria formação do coordenador pedagógico que discutia, com os cursistas, conhecimentos e habilidades necessárias para a atuação frente às demandas específicas de alfabetização nos Ciclos I e II. Esse projeto foi concebido a partir das necessidades formativas apontadas pelos coordenadores, e era sistematicamente re-elaborado depois de cada encontro e procurava incorporar ao currículo da formação as demandas e as contribuições da prática da coordenação pedagógica socializada no curso.

Simultaneamente participei do Grupo de Acompanhamento da Ação Educativa $\left(\mathrm{GAAE}^{5}\right)$, que, na época, estava num processo de construção de identidade. Esse grupo, inicialmente era composto por um elemento de uma universidade, fazendo parte do grupo e dando assessoria, um supervisor e um STE - como figuras externas à escola -, o coordenador pedagógico e o diretor de cada unidade, tinha a função de acompanhar o projeto políticopedagógico (PPP) das escolas, particularmente a formação docente desenvolvida na época na JEI por meio do Projeto Especial de Ação $\left(\mathrm{PEA}^{6}\right)$, assessorando a escola ou o grupo de escolas em suas solicitações formativas. Segundo o documento Educ Ação nº 2:

Esta composição objetiva estimular e assegurar o necessário e desejado diálogo entre NAEs ${ }^{7} /$ Escolas e Universidades. A participação da Universidade integrando os GAAEs e também a assessoria aos Pólos se constitui, em um modo de fazer diferenciado, que valoriza e considera a inter-relação do conhecimento científico com os conhecimentos acumulados pelas escolas.(p.12)

Quando ingressei no GAAE, esse modelo de acompanhamento já havia se transformado: o profissional ligado à universidade só era contatado, a partir de um projeto específico de uma escola ou grupos de escolas (formação em rede), para favorecer o

3 A Coordenadoria de Educação é um órgão intermediário da administração pública da Secretaria de Educação do Município de São Paulo, atualmente denominada Diretoria Regional de Educação.

$4 \quad$ O STE é o funcionário designado ou contratado para prestar Serviço Técnico Educacional em órgão intermediário ou central da Secretaria Municipal de Educação. Em 2002, o organograma da SME era: Gabinete do Secretário, Diretoria de Orientação Técnica (DOT); Superintendência Municipal de Educação (SUPEME); Coordenadoria de Educação; Escola. Nesta escola, de acordo com a modalidade de ensino, tínhamos compondo as equipes escolares: diretor, assistente de diretor; coordenador pedagógico (um para as EMEIs, dois para EMEFs e três para EMEFMs), professores, agentes e alunos.

5 A configuração do GAAE, conforme discriminada, está expressa no documento Educ-Ação n².

6 A sigla PEA refere-se aos Projetos Especiais de Ação, normalmente configurados como projetos de formação na escola. São regulados por Portarias, conforme descrito no Capítulo III.

7 O NAE era o Núcleo de Ação Educativa, órgão intermediário do sistema de ensino, atualmente corresponde à Diretoria Regional de Educação (DRE). 
desenvolvimento da formação pretendida pela equipe docente, tendo em vista uma dificuldade pedagógica específica. Nesse caso, o coordenador pedagógico era o elo entre o desejo do grupo e a equipe da coordenadoria que, por sua vez, mobilizava os agentes da universidade ${ }^{8}$. Essa experiência foi rica pela possibilidade de acompanhamento do horário coletivo de trabalho pedagógico e seus respectivos coordenadores pedagógicos, por vezes, pensando com os coordenadores a formação contínua do professor na escola, ouvindo seus questionamentos ou simplesmente acompanhando as discussões no grupo.

Minha participação no Programa Salto para o futuro da TV Escola, em 2005, discutindo a formação contínua de professores, foi mais uma oportunidade para me aproximar da realidade dos coordenadores pedagógicos que desenvolvem sua atividade profissional no território nacional. Essa vivência possibilitou-me um contato com coordenadores pedagógicos de várias regiões do Brasil e percebi que era unânime a preocupação com a falta de um espaço/tempo ${ }^{9}$ específico para promover a formação docente na escola e com o envolvimento dos professores nesse processo. As falas representativas das condições dadas a esses profissionais demonstraram que havia o mesmo sentimento de impotência entre os coordenadores de vários municípios e estados brasileiros.

Essa situação revelou-me o quanto o trabalho da coordenação pedagógica, no Brasil, ainda é disperso, pois falta um estatuto profissional que garanta certa unidade e coerência dessa ação nos estados e nos municípios em que esse profissional atua. Em alguns estados, a função de coordenador pedagógico é exercida pelo supervisor escolar. Em outros, esse cargo ou essa função, especificamente, não existe e, nos casos em que os estados ou municípios adotam a figura do coordenador pedagógico, as condições de trabalho são tão diversas que se torna difícil estabelecer relações entre as ações desses profissionais.

Mesmo considerando a diversidade de designação dos profissionais que exercem a função de coordenar o trabalho pedagógico na escola, o fato comum, no cenário acadêmico e político nacional, é que cada vez mais esses profissionais assumem, independente das condições de tempo, espaço e materiais, a responsabilidade pela formação de professores na escola. Em virtude dessa demanda, esta pesquisa centrou suas bases na reflexão sobre o papel

\footnotetext{
8 A contratação de profissionais ligados a uma universidade para prestar assessoria era um processo demorado, visto que os trâmites legais implicavam análise do currículo dos interessados, a composição de uma lista tríplice de especialistas em suas áreas, para desenvolver o tema solicitado, além de considerar, na escolha, a menor remuneração cobrada, quer por assessoria institucional (universidade) ou pessoal.

9 A falta de tempo e espaço para a formação diz respeito às condições 'dadas' aos profissionais para o desenvolvimento profissional. Algumas vezes, esse tempo/espaço pode ser uma construção local apoiada pelo PPP da unidade escolar; outras vezes, apenas o apontamento de uma necessidade local, mas em ambos os casos é necessária uma política pública comprometida com a formação contínua dos professores, no locus de trabalho, para que esse tempo/espaço se configure como uma possibilidade real de formação.
} 
do coordenador pedagógico como organizador dos espaços coletivos de formação contínua na escola.

A própria estrutura da Rede Municipal de Ensino de São Paulo foi se configurando de maneira a estabelecer, de tempos em tempos, novos enfoques para a função do coordenador pedagógico. A criação da JEI, na década de 1990, ampliou o tempo dos professores na escola, oportunizando o planejamento, a execução e a reflexão sobre a prática desenvolvida. A coordenação, assim, amplia seu espaço de atuação com o docente, pela oportunidade de coletivamente recriar a prática de maneira crítica, de modo a melhorar a qualidade do ensino oferecido às crianças e aos jovens, caracterizando-se por desempenhos que promovem o desenvolvimento profissional do docente na escola.

Essa ideia ganhou forma e estrutura por meio de portarias ${ }^{10}$ que dispunham sobre a organização dos Projetos Especiais de Ação (PEAs) nas escolas municipais de São Paulo. Dessa forma, elas vão institucionalizando a formação na escola e moldando, a cada tempo, tais projetos de acordo com as concepções que mobilizam o trabalho nas administrações públicas. Contudo, essas orientações foram restringindo a autonomia da escola em relação aos projetos de formação nela desenvolvidos.

Paralelamente ao desenvolvimento da pesquisa, fui acompanhando, nos últimos quatro anos (2005 a 2008), algumas mudanças na organização das escolas municipais por meio dos instrumentos legais. O governo, cuja gestão compreendeu o período de 2005 a 2008, pretendia, entre os programas de governo, a re-estruturação do estatuto dos profissionais de educação, organizado, em 1992, após amplo debate entre os profissionais, constituindo-se na Lei $n^{\circ} 11.229 / 1992$, reformulada pela Lei ${ }^{\circ} 11.434$ de 1993 e pela Lei $n^{\circ} 12.396$ de 1997 . Essas mudanças na legislação, que envolveram todas as escolas públicas municipais, levam a um particular interesse, neste trabalho, em virtude das discussões que se seguiram sobre as jornadas de trabalho e a coordenação pedagógica.

A principal preocupação dos docentes, durante as negociações para a reformulação da carreira do magistério municipal proposta em 2006, era a redução da Jornada Especial Integral (JEI) e as possíveis alterações nas leis que regiam os reajustes dos servidores. Uma das propostas que compunha a primeira versão do documento era a transformação do cargo de coordenador pedagógico em 'vice-diretor pedagógico ${ }^{11}$, e do supervisor em 'técnico regional de educação', mas para essas mudanças não foram apresentadas justificativas. Contudo, no final das negociações, os cargos acabaram por manter suas estruturas e denominações. Após

10 Antes da primeira Portaria do PEA, a de $N^{\mathrm{o}} 2083 / 1994$, o comunicado $\mathrm{N}^{\mathrm{o}}$ 126/1993 foi o primeiro documento legal que orientou a elaboração do então denominado Projeto Estratégico de Ação que organizava o uso do horário coletivo proporcionado pela JEI, que passou a vigorar a partir da publicação do Estatuto do Magistério Público Municipal - Lei 11.229 em junho de 1992. 
os encontros entre o governo e os sindicatos, resultado de um período de greve dos educadores, o documento foi sendo reconfigurado até a sua última organização em 2007, a Lei n ${ }^{\circ}$ 14.660/07, intitulada "Estatuto dos Profissionais de Educação do Ensino Municipal de São Paulo". O documento final não apresentou alteração na composição da Jornada Especial Integral (JEI), porém o nome da jornada foi alterado para Jornada Especial Integral de Formação (JEIF).

A mudança da denominação da jornada, embora, aparentemente, não representasse uma modificação significativa, é reveladora do peso que se atribui à formação na escola, que já era explícito nas indicações das Portarias de PEAs. A redundância da associação entre as orientações sobre o projeto e o nome da jornada não deixa dúvidas sobre sua determinação: ambas cumprem o papel de reforçar essa prerrogativa do horário coletivo como a desejável.

Mesmo não havendo alteração em relação às atribuições do cargo de coordenador pedagógico, outras modificações aconteceram. O número de coordenadores, nas escolas de ensino fundamental, foi alterado. Antes elas se organizavam com dois coordenadores, independente do número de turmas, atualmente o número desses profissionais está limitado à quantidade de turmas organizadas na unidade educacional, o que significa que as unidades menores ficaram com apenas um coordenador pedagógico e as maiores poderiam ter até três coordenadores $^{12}$. As escolas de educação infantil que sempre trabalharam com um coordenador, independente do número de turmas, continuaram com um coordenador. A pretensão era que o mínimo de coordenadores por escola fossem dois, para acompanhar o processo pedagógico em todos os períodos, fazer as intervenções necessárias e discutirem alguns encaminhamentos.

Embora as mudanças pareçam simples, elas se constituem em parte da dinâmica das políticas públicas, que, ao reorganizarem o estatuto dos profissionais de educação, revelam suas concepções de educação e estabelecem um controle ainda maior sobre esses profissionais.

Essas alterações no sistema de ensino municipal de São Paulo foram alimentando as minhas ideias iniciais sobre um trabalho cujo enfoque estaria na ação do coordenador pedagógico na formação contínua do docente na escola, e que foram geradas pela motivação primeira que me trouxe de volta à universidade, ou seja, a relação entre a atuação do

\footnotetext{
11 Conforme explicitado no informativo do Sindicato dos Profissionais em Educação no Ensino Municipal de São Paulo (SINPEEM) de setembro de 2007, Anexo A.

12 A Portaria 1.003, de 14/02/2008 institui o quadro de lotação de profissionais nos cargos específicos das unidades escolares. Em relação ao coordenador pedagógico, a Portaria estabelece que, nas Escolas de Educação Infantil e nos Centros de Educação Infantil, haverá um coordenador; nas Escolas Municipais de Ensino Fundamental com até 14 classes, haverá um por unidade; nas escolas que têm entre quinze e cinquienta classes, haverá dois coordenadores e nas que possuem acima de cinqüenta classes, três coordenadores pedagógicos.
} 
coordenador pedagógico, no horário coletivo, e o desenvolvimento profissional do professor, aspecto esse tratado tangencialmente em minha dissertação de mestrado ${ }^{13}$.

O olhar de políticos e teóricos, focados na escola, tem revelado que o espaço escolar pode e deve constituir-se em lugar de aprendizagem também para o professor, caracterizandoo como locus de formação do docente. Isso implica antever o papel multifacetado da gestão escolar, articuladora das ações pedagógicas, e em especial as do coordenador pedagógico que, como gestor pedagógico, é responsável, no espaço escolar, pela formação docente.

Vale destacar que a coordenação pedagógica, cujo papel está pautado pelo acompanhamento sistemático da prática pedagógica dos professores, possui uma série de atribuições, normalmente descritas no regimento ${ }^{14}$ das escolas, entre as quais: responder pelas atividades pedagógicas da escola; acompanhar na sala de aula a atividade do professor; supervisionar a elaboração de projetos; discutir o projeto político-pedagógico; prestar assistência ao professor; coordenar reuniões pedagógicas; organizar as turmas de alunos e acompanhar os processos de avaliação; organizar a avaliação da escola; cuidar da avaliação do corpo docente e do plano pedagógico; atender pais e alunos em suas dificuldades; e propor e coordenar ações de formação contínua do docente na escola, considerando a relação intrínseca entre o fazer pedagógico e a reflexão sobre a prática educativa.

Nóvoa (1992) faz uma análise que justifica a concepção da formação centrada na escola. Primeiro, por ser o lugar onde se desenvolve o currículo de formação do aluno, nesse caso, ela se volta para as dificuldades do docente e para a concepção pedagógica expressa no projeto político-pedagógico da unidade escolar. Segundo, porque, ao contrário de outros lugares que orientam esse processo por uma única concepção científica, a escola possibilita mobilizar diversos saberes, tradições e correntes científicas. Terceiro, porque favorece a troca

13 A dissertação $O$ horário de trabalho coletivo e a (re)construção da profissionalidade docente foi defendida em abril de 2004 e analisa os limites e as possibilidades da formação desenvolvida no horário de trabalho coletivo para a (re)construção da profissionalidade docente, aspecto esse estudado sob a ótica do professor e não da do coordenador.

O regimento é o documento que direciona as ações da escola em todos os aspectos das relações com a comunidade e das relações com os órgãos superiores, também organiza as atividades profissionais a partir da determinação do que é responsabilidade de cada segmento. Até 1996, as escolas da Prefeitura de São Paulo tinham um regimento comum, ou seja, o mesmo regimento para todas as escolas, salvo algumas especificidades relacionadas ao nível de atendimento das EMEIs, EMEFs, EMEFMs etc., e ao corpo de funcionários que deveriam compor cada segmento. No entanto, a Constituição Nacional de 1988 e a LDB, Lei n 9394/96, trouxeram como demanda o discurso de autonomia da escola, portanto, a necessidade de um regimento específico para cada instituição educativa. A partir de 1997, a Rede Municipal de Ensino de São Paulo, por meio de legislação própria, traçou coordenadas para que cada estabelecimento de ensino elaborasse seu regimento em consonância com a legislação em vigor que, após aprovação pelo Conselho de Escola, foi encaminhado ao Conselho Municipal para sua deliberação e publicação. Esse último regimento pode ser alterado pelos profissionais da escola, a qualquer tempo, desde que haja alguma mudança estrutural. Observa-se, no entanto, pouca diferença entre as funções dos profissionais de educação descritas no regimento anterior e deste, elaborado pelas escolas. Especificamente, as atribuições do coordenador pedagógico previstas no regimento de cada escola são reguladas pelo Decreto $\mathrm{n}^{\mathbf{o}} 33.991 / 94$, que dá as mesmas diretrizes para todos os regimentos das escolas municipais de São Paulo. 
de experiências, que representa a partilha de saberes, e promove o caminho para a produção de conhecimentos reflexivos e pertinentes à atuação dos professores. Por fim, a escola incluise no contexto de formação do docente em virtude das mudanças no campo do conhecimento que tem valorizado a epistemologia da prática, os processos de autoformação, os investimentos educativos nas situações profissionais e a autonomia dos estabelecimentos de ensino.

A escola, dessa forma, vem sendo ressignificada pela possibilidade de enxergar-se como 'escola reflexiva' (ALARCÃO, 2001) e como lugar onde o professor aprende (CANÁRIO, 2006; NÓVOA, 2002; LIBÂNEO, 2003). Essas ideias estão associadas a uma equipe que esteja voltada para a reflexão de suas práticas, de seus caminhos metodológicos e de sua concepção. Portanto, voltada para a organização de espaços e tempos que produza uma reflexão crítica sobre a prática pedagógica.

Somam-se, a esse aspecto, as pesquisas atuais que enfatizam a importância da reflexão sobre as práticas escolares para o desenvolvimento profissional docente (MARCELO GARCIA, 1999; NÓVOA, 1992; PIMENTA, 2002b) e, ainda, o conceito de professor como produtor de saber (SACRISTAN; PÉREZ GOMES, 2000; CONTRERAS, 2002; GIROUX, 1997; PIMENTA, 2005), capaz de reflexivamente pensar sua ação, articulando os saberes pedagógicos, o conhecimento curricular e os saberes da experiência construídos e reconstruídos no processo formativo.

Nesse contexto epistemológico, que acentua o debate sobre o papel da escola como locus de desenvolvimento profissional do docente, pela oportunidade de os professores refletirem coletivamente sobre seus saberes e saberes-fazeres, é que ganha sentido o papel do coordenador pedagógico como articulador dos espaços coletivos de formação contínua do docente na escola.

Para ampliar a reflexão sobre a ação do coordenador pedagógico, objeto sobre o qual incide esta pesquisa, foi necessário investigar as dissertações e teses desenvolvidas e defendidas entre 1988 e 2004 que tratam dessa temática. As bases de dados utilizadas foram: o banco de dissertações e de teses da CAPES (trinta e três títulos encontrados), o livro de Teses e dissertações defendidas na FEUSP de 1967 a 1998 (um título apenas encontrado) e a biblioteca da PUC-SP (quatro títulos encontrados), excluindo-se os dados em duplicidade que aparecem no portal CAPES. A análise dos resumos, das palavras-chave e dos procedimentos metodológicos favoreceu o direcionamento do percurso dessa temática nas três últimas décadas, situou epistemologicamente o tema abordado e revelou trabalhos que poderiam ser agrupados em duas categorias amplas: (a) a identidade do coordenador pedagógico e sua relação com os professores e (b) o coordenador pedagógico e a formação em serviço, essa última mais próxima do objeto desta pesquisa. 
A leitura na íntegra dos trabalhos, que se relacionam mais diretamente com a temática de meu interesse, possibilitou-me apontar certa carência na produção acadêmica de conhecimentos específicos sobre como o coordenador pedagógico organiza o espaço/tempo da formação na escola, considerando os limites e as possibilidades do real.

A contribuição das dissertações e das teses analisadas está relacionada, principalmente, a uma abordagem epistemológica que considera os saberes dos profissionais envolvidos - professores e coordenadores pedagógicos -; às definições do campo da formação inicial e contínua bem como aos aspectos da subjetividade que caracterizam o campo educacional. Essas características são evidenciadas em algumas abordagens específicas como: as representações dos coordenadores pedagógicos em relação à formação contínua e aos saberes dos educadores (FUSARI, 1997; CHRISTOV, 2001); a análise da identidade dos coordenadores pedagógicos (PÉREZ, 1992; BLANDINO, 1996); a afinidade desses profissionais com os professores (SALVADOR, 2000); a valoração da ação formativa desenvolvida pelo coordenador pedagógico (VIANA, 2001) e a construção histórica do percurso desse profissional (GARCIA, 1995; FUSARI, 1997; PÉREZ, 1992). Tais reflexões me ajudaram a focar o objeto de pesquisa, dada a especificidade da formação contínua abordada.

Em minha pesquisa anterior, $O$ horário de trabalho coletivo e a (re)construção da profissionalidade docente, engendrei algumas ideias que ajudam a pensar a escola como espaço de formação do professor e cujas reflexões estabelecem alguns limites e algumas possibilidades para esse trabalho. Tais análises constituem-se em um ponto de partida que medeia a reflexão sobre a ação formadora do coordenador pedagógico, ou seja:

-a formação contínua, tão diretamente ligada à escola e a seus problemas educativos específicos, pode converter-se num reducionismo formativo que acaba por gerar projetos do tipo "apaga-fogo' ${ }^{15}$ e que pode se revelar frustrante por estar desvinculada de uma visão ampla dos problemas educacionais e da sua contextualização social;

-tal situação pode dificultar um distanciamento da prática para a reflexão necessária. Assim como os cursos oferecidos tradicionalmente 'pecam' pelo afastamento da prática educativa, uma aproximação exagerada pode impedir que se vejam os limites da prática e as contribuições da teoria;

- e espaço formativo na escola pode reforçar o movimento que culpabiliza o professor pelo fracasso escolar, especialmente quando a formação realizada na escola não resolver os problemas do seu cotidiano;

15 Projetos que incidem sobre uma situação imediata e localizada. 
- o professor pode sentir-se abandonado à própria sorte, pelos órgãos públicos, e resistir às mudanças. (DOMINGUES, 2004, p. 147)

Nessa perspectiva, propor a melhoria da qualidade do ensino, tendo como princípio a formação contínua na escola, significa pensar a complexa tarefa desenvolvida pelo coordenador pedagógico e as condições necessárias para que esse profissional atue de modo a favorecer a articulação do projeto pedagógico da escola, os momentos coletivos de reflexão, a troca de experiência ${ }^{16} \mathrm{e}$ as demandas relacionadas ao acompanhamento da ação pedagógica.

Ainda, é preciso considerar que a política educacional brasileira, muitas vezes atrelada a determinantes históricos, econômicos e sociais ligados ao cenário nacional e internacional, despreza as peculiaridades regionais e locais no que diz respeito ao papel contemporâneo da educação e da gestão educacional. Consequentemente, os projetos elaborados e desenvolvidos em nível micro (escola), orientados a partir desses pressupostos, manifestam as determinações das reformas educacionais, muitas vezes voltadas para a ampliação da oferta, do acesso e do atendimento à demanda nas escolas públicas, mas pouco focadas no êxito escolar e no trabalho de formação dos professores na escola, pautado nas demandas pedagógicas.

No passado, essa situação gerou uma tensão nas escolas em virtude da grande porcentagem de repetência e, posteriormente, de desistência dos alunos e propiciou, dentre outros fatores, na década de 1980, por determinação da política educacional, a criação do cargo $^{17}$ de coordenador pedagógico ou professor-coordenador pedagógico, assim denominado na Rede Estadual de Educação de São Paulo.

As mudanças educativas, o desenvolvimento tecnológico, as mudanças políticas, as reformas educativas e as mudanças sociais impõem ao trabalho pedagógico uma dinâmica particularizada a cada tempo, espaço, currículo, comunidade atendida e isso exige adequações da escola e de seus profissionais. O coordenador pedagógico precisa estar sensível a essa dinâmica que, em certa medida, orienta a formação necessária ou aponta as necessidades docentes.

As solicitações do poder público em relação ao trabalho da coordenação pedagógica, não poucas vezes, estão associadas a um movimento de implantação das políticas públicas,

\footnotetext{
16 Fusari $(2007$, p. 153) ao referir-se às representações das professoras aposentadas sobre formação contínua afirma que "a troca de experiência entre professores é um procedimento antigo que garante a superação de dificuldades surgidas no trabalho em sala de aula, ao mesmo tempo que funciona como formação profissional em serviço". Durante a pesquisa, foi possível compreender que a expressão 'troca de experiência' se referia tanto a uma troca de opiniões quanto a elaboração coletiva e crítica de uma atividade a ser desenvolvida com os alunos (seqüência didática). Entende-se que a troca de experiência como elemento da formação do educador pressupõe uma metodologia. Quem troca experiência deve contextualizá-la e descrevê-la. Quem ouve uma experiência deve saber que precisa refletir sobre ela e, então, decidir se cabe ou não na sua prática pedagógica, para depois adaptá-la.
} 
objetivando adequar o sistema de ensino ao projeto pedagógico assumido pelos gestores das políticas públicas.

Esse movimento traz explícito um discurso de 'qualidade' na educação e 'qualidade' da escola. A noção de qualidade educacional muitas vezes se confunde com a concepção neoliberal de qualidade, ligada à economia, entendida como 'qualidade total' que, aplicada ao sistema escolar, tem basicamente como objetivo o treinamento de pessoas para serem competentes no que fazem (LIBÂNEO, 2003, p. 53,54). Ainda, segundo esse autor:

Entre as medidas decorrentes dessa concepção organizacional destacam-se: a
hipervalorização dos resultados da avaliação, a classificação das escolas em
função desses resultados para estimular a competição entre elas, a
descentralização administrativa e do repasse de recursos conforme
desempenho das escolas na avaliação externa, as parcerias com a iniciativa
privada, o repasse das funções do Estado para a comunidade (pais) e para as
empresas. Em resumo, a qualidade total decorre de uma concepção
economicista, empresarial, pragmática.

O autor opõe, à ideia neoliberal de qualidade, o conceito de 'qualidade social' da Educação entendida, basicamente, como aquela que promove o "[...] domínio do conhecimento e das capacidades cognitivas, operativas e sociais necessários ao atendimento das necessidades individuais e sociais dos alunos [...]" (p. 54) em prol da cidadania e da construção de uma sociedade mais justa. Segundo Tragtenberg (1985):

[...] escola se constitui num observatório político, num aparelho que permite o conhecimento e controle perpétuo de sua população através da burocracia escolar, do orientador educacional, do psicólogo educacional, do professor ou até dos próprios alunos. (p.41)

Considerando esses aspectos, infere-se que o coordenador pedagógico pode estar submetido a uma hierarquia administrativa e pedagógica que controla e disciplina sua ação, principalmente no que diz respeito à coordenação dos projetos de formação docente, que podem dar vazão ao poder do Estado, quando determinam quais projetos podem ser desenvolvidos, quer por decretos ou pareceres, quer pelo controle dos órgãos intermediários da administração pública.

As tendências que influenciam a educação igualmente encerram uma concepção da ação da coordenação pedagógica, que pode assumir desde características de supervisão pedagógica até de gestão das decisões tomadas coletivamente, ambas as formas compõem-se

17 A reforma do Curso de Pedagogia em 1968 já introduzia as habilitações em administração escolar, orientação educacional e supervisão escolar. No entanto, não se falava da coordenação pedagógica nos moldes 
com a cultura escolar e configuram-se numa rede de ações que a identifica. Visto dessa forma, é inconsistente examinar a ação do coordenador desvinculada dessas influências que podem, em menor ou maior grau, constituí-la.

A ação da coordenação pedagógica nas escolas deve estar vinculada ao projeto político-pedagógico e precisa ser alvo de reflexão dos componentes da equipe escolar (pais, alunos, professores, direção e da própria coordenação) para que, asseguradas as condições mínimas de tempo (para formação contínua; reunião de pais; atendimento de alunos; preparo de material para a intervenção etc.) e lugar (para os encontros com os professores; pais; alunos; leitura e reflexão do coordenador pedagógico etc.), o trabalho do coordenador pedagógico evidencie o projeto de gestão da escola e de formação de todos os envolvidos (alunos, professores, pais, funcionários etc.).

Desse modo, as ações da escola sistematizadas no projeto político-pedagógico compõem as premissas que orientam o trabalho pedagógico e apontam as necessidades e as possibilidades do trabalho de formação desenvolvido pelo coordenador pedagógico em diversas direções conceituais. Portanto, a organização do espaço formativo pelo coordenador pedagógico, referendado ou não pelo coletivo escolar, sinaliza a não-neutralidade das concepções ventiladas, o que implica decisões sobre como tratar o professor e sobre a sua formação em serviço.

A ideia de uma escola reinventada ou cujas organização e gestão têm caráter profundamente democrático (ALARCÃO, 2001; LIBÂNEO, 2003) tem exigido dos envolvidos pensar novas formas de organização, de funcionamento e de desenvolvimento da profissionalização e da profissionalidade de todos, formas que concentrem sistematização e vontade de promover o autodesenvolvimento profissional.

A atuação da coordenação pedagógica, assim, passa a ser entendida não mais como uma atividade meramente técnica e burocrática, mas uma prática intelectual que se modifica em função do tempo histórico, das mudanças sociais e políticas e das experiências vivenciadas pelos educadores no contexto educativo.

A combinação desses fatores corrobora a construção da tese, assim formulada: o trabalho do coordenador pedagógico na formação contínua centrada na escola é um 'saberfazer' multideterminado, decorrente da formação pessoal, da organização institucional e das políticas públicas.

Este estudo objetiva ampliar os conhecimentos referentes à ação do coordenador pedagógico, principalmente às práticas relacionadas aos espaços institucionalizados de formação, motivado pela problemática constituída em torno dos limites e das possibilidades 
desses sujeitos desenvolverem projetos de formação contínua considerando a não consolidação da autonomia da escola e as dificuldades em virtude de uma competência profissional pouco estruturada. Para tanto, toma como objeto de investigação o papel do coordenador pedagógico como gestor do espaço/tempo coletivo de formação contínua na escola.

Frente a essas considerações, algumas questões foram delineadas e consideradas fundamentais:

-Quais limites e possibilidades o coordenador pedagógico encontra e cria ao investir na organização da formação contínua do docente nas escolas municipais de São Paulo?

-Quais são os limites políticos da atuação do coordenador pedagógico?

-Em que medida a falta (ou a precariedade) da formação do coordenador pedagógico interfere na gestão da formação contínua na escola?

-Em que aspectos se manifesta a autonomia (ou sua ausência) da escola na gestão de seus projetos de formação?

- Como e em quais condições o coordenador pedagógico organiza o horário coletivo de formação contínua?

•É possível que a formação contínua na escola, organizada pelo coordenador pedagógico, se constitua num trabalho emancipador ${ }^{18}$ ?

Partindo dos questionamentos que problematizam a atuação da coordenação pedagógica, é possível trabalhar com duas hipóteses:

- Os limites e as possibilidades da gestão da coordenação pedagógica, na escola pública municipal de São Paulo, estão relacionados à natureza pessoal dos coordenadores: à política pública relativa à educação, seus objetivos e compromissos; à cultura escolar; e às características do grupo com que deverá trabalhar;

-Para uma gestão inovadora e geradora de mudanças qualitativas dos espaços pedagógicos, é necessário que a ação da coordenação não esteja descolada de um projeto de escola e de uma gestão comprometida com o enfrentamento e a solução dos problemas pedagógicos, com a construção do trabalho coletivo, tendo como meta a oferta de um ensino de qualidade para todos.

\footnotetext{
18 Neste trabalho, o termo 'emancipação' está associado à autonomia profissional e é compreendido, conforme Contreras (2002, p.185): "Enquanto emancipação, a autonomia suporia um processo contínuo de descobertas e de transformação das diferenças entre nossa prática cotidiana e as aspirações sociais e educativas de um ensino guiado pelos valores da igualdade, justiça e democracia. Um processo contínuo de compreensão dos fatores que dificultam não só a transformação das condições sociais e institucionais do ensino, como também de nossa própria consciência".
} 
Tomando como diretrizes essas considerações, o objetivo principal foi definido como:

-Investigar como o coordenador pedagógico organiza e implementa a formação contínua desenvolvida no horário coletivo, considerando a relativa autonomia da escola e seus saberes sobre a articulação da formação no espaço escolar.

Outros foram estabelecidos como secundários:

-Identificar a influência das políticas públicas nas tensões e intenções que orientam os processos de formação do próprio coordenador pedagógico e dos professores;

- Desvelar as consequencias da adesão e da resistência do coordenador pedagógico em relação às políticas que orientam o desenvolvimento da função;

- Contribuir para o autodesenvolvimento profissional do coordenador pedagógico e para a produção de conhecimento sobre a atuação da coordenação pedagógica;

- Contribuir para a melhoria do processo de ensino-aprendizagem nas escolas.

O coordenador pedagógico na escola assume, dentre diversas atribuições, a formação do docente na escola ${ }^{19}$. O seu trabalho transita, grosso modo, entre o acompanhamento das atividades didático-pedagógicas e a coordenação das ações que visam o desenvolvimento profissional dos professores.

Investigar a atuação desse profissional na formação contínua dos professores na escola é questionar verdades, abrir feridas, buscar respostas ${ }^{20}$. Este estudo considera a influência da cultura escolar e das políticas públicas na gestão de tais projetos de formação desenvolvidos nas escolas e procurará, por meio de análises de práticas formativas, refletir sobre o que as caracteriza sob a perspectiva da atuação do coordenador pedagógico.

A pesquisa foi desenvolvida durante o último semestre de 2006 e o primeiro de 2007 , no contexto de duas escolas municipais onde transcorreu o acompanhamento de horários coletivos de trabalho pedagógico em que os coordenadores pedagógicos vivenciavam a prática de coordenar os projetos de formação contínua.

Ao longo desse processo de investigação alguns aspectos destacaram-se como elementos de reflexão sobre a própria pesquisa:

\footnotetext{
19 Existem outros espaços/tempos de formação na escola que geralmente estão relacionados às atividades interpessoais no ambiente escolar. Portanto, é possível o docente aprender nos corredores, na sala dos professores, com os colegas, num mural etc., mas esse não é o foco deste trabalho, que analisa o espaço institucional criado para a formação do docente na escola.

20 Respostas essas que, segundo nossa perspectiva, não farão da figura do coordenador pedagógico o redentor da educação nem dos espaços/tempo de formação na escola (JEIF e outros), a solução para os problemas educacionais.
} 
- A complexa teia de relações que envolve a pessoa do coordenador, suas opções, sua formação, a instituição escolar e os projetos;

- A importância da formação na escola, como uma categoria de formação, que não exclui a necessidade de outras formas;

- A formação do coordenador pedagógico como um dos elementos que possibilita uma ação de formação eficaz;

- A rede municipal de ensino de São Paulo que, com suas políticas e histórias de resistências e de adesões, foi configurando a formação contínua e o papel do coordenador pedagógico.

O trabalho encontra-se organizado, além dessa introdução, do seguinte modo: o primeiro capítulo descreve o processo da pesquisa buscando fundamentar sua natureza, os instrumentos metodológicos utilizados para coleta de dados, a caracterização das escolas envolvidas, determinando as escolhas procedidas. O segundo capítulo situa a coordenação pedagógica, apresentando a gênese dessa função na cidade, que se confunde com a história das escolas municipais de São Paulo. O terceiro capítulo traz uma análise que procura identificar, nas referências teóricas e nos dados coletados, a importância e a influência do projeto político-pedagógico, que viabiliza a escola como locus de formação; no papel do coordenador pedagógico, como eixo articulador dessa formação no espaço escolar. O quarto capítulo objetiva refletir sobre o coordenador como articulador da formação contínua na escola, fazendo uma análise dos desafios dessa ação. Por fim, a conclusão busca apresentar, diante do apurado, alguns limites e possibilidades da ação do coordenador pedagógico na formação centrada na escola. 


\section{A PESQUISA E SEU DESENVOLVIMENTO}

O homem vai atingindo o conhecimento de si na medida em que se revela. Esse conhecimento de si cresce à medida que o homem procura conhecer o outro e esse conhecimento do outro só ocorre quando existe uma perfeita identificação entre o eu e o outro, ou seja, o homem só se realiza, só se conhece no encontro com o outro.

Ivani Catarina Arantes Fazenda

Pesquisar, tendo como objeto profissionais que refletem e desenvolvem uma atividade mediada pelo tempo, pelo espaço e por compreensões diversas, é considerar o aspecto 
dinâmico que caracteriza as ações humanas e sua relação com a cultura. Nesse caso, os professores, a escola, entendida como locus de formação, e o coordenador pedagógico fazem parte de uma mesma trama que identifica o contexto escolar como local de produção de conhecimento.

Como diz a autora em epígrafe, o homem só se realiza e se conhece no encontro com outros homens. A formação contínua constitui-se em parte dessa busca de conhecimento que também é autoconhecimento e cujo sentido está na relação humana, suas histórias, suas descobertas, seus modos vivendi, de conhecer, de produzir e de trabalhar.

Como apontado na introdução, a proposta desta pesquisa nasceu em virtude da minha própria experiência como coordenadora pedagógica da Rede Municipal de Ensino de São Paulo, desenvolvendo projetos para a formação contínua dos docentes na escola. O trabalho na formação contínua compõe parte da função da coordenação pedagógica que é pouco explicitada, se considerarmos a curta existência dessa modalidade de formação e as contradições dos discursos que ora reforçam a autonomia da escola, ora apresentam demandas que ferem essa autonomia.

Por se tratar de uma investigação que tem como enfoque o trabalho do coordenador pedagógico na formação centrada na escola, são ressaltados alguns aspectos inerentes à escola, sua função socializadora de conhecimentos para alunos e professores, a diversidade dos profissionais que por ela circulam, o papel do coordenador pedagógico e os saberes sobre o desenvolvimento profissional docente tomados como referência para a articulação da formação. Pesquisar sobre o coordenador pedagógico no espaço escolar é mergulhar na complexidade da instituição escolar que a caracteriza como lugar de aprendizagem.

A proposta desta pesquisa consiste em analisar, de forma sistemática, a atividade do coordenador pedagógico no desenvolvimento da formação centrada na escola. Para tanto, orienta-se pela seguinte tese: $O$ trabalho do coordenador pedagógico na formação contínua centrada na escola é um 'saber-fazer' multideterminado, decorrente da formação pessoal, da organização institucional e das políticas públicas. Explicitar esses pressupostos significa discutir como base teórica a formação contínua centrada na escola e o papel do coordenador pedagógico.

O que justifica este capítulo é trazer ao leitor as motivações e o percurso metodológico desenvolvido. Grosso modo, podemos dizer que as dúvidas e as inquietações pessoais motivaram esta investigação e que o caminho metodológico procura criar uma visibilidade crítica sobre os saberes e os fazeres dos coordenadores pedagógicos, pedagogos não docentes que acumulam a responsabilidade pelo desenvolvimento de projetos de formação de 
professores em serviço. Tendo esses profissionais sua atuação lotada na escola pública, constituem-se em um dos agentes de mudança na escola e, especialmente, parceiros no processo de descoberta sobre si mesmos e a profissão.

\title{
1. A construção metodológica - o objeto e o contexto da pesquisa
}

A atividade educativa desenvolvida na escola é realizada por homens em interação com outros homens, trabalhando com o conhecimento que também é uma produção humana, num ambiente que favorece a diversidade social. Nesse contexto que estabelece a complexidade dos fenômenos educativos, a descoberta e a interpretação aparecem em oposição à mensuração dos dados. Segundo Franco (2003, p. 189):

\begin{abstract}
A pesquisa em educação carrega diversas peculiaridades, pois trabalha com um objeto de estudo multidimensional, mutante, complexo, em que o caráter sócio-histórico de suas práticas faz com que cada situação educativa seja sempre única, irreptível, com imensas variações no tempo, no espaço, nas formas organizativas de sua dinâmica e no caráter de sua intencionalidade.
\end{abstract}

Essas peculiaridades da pesquisa em educação é que a tornam, também, complexa, pois estabelecem como parâmetro da pesquisa uma construção metodológica em contexto, ou seja, delineada pelo objeto e pelos pressupostos iniciais, mas organizada e finalizada no processo da investigação. Longe de caracterizar a pesquisa em educação como extremamente fluida e sem controle, o que se pretende é mostrar que a opção por uma abordagem qualitativa $^{21}$ buscou melhor captar as faces do problema, o que não se daria por uma metodologia menos flexível e mais pré-determinada.

Sendo assim, a opção metodológica num trabalho científico não se caracteriza apenas por uma escolha de técnicas a serem aplicadas, mas, sobretudo, um processo de reflexão sobre o próprio ato de pesquisar em função do problema a ser estudado. Essa análise do método, quando mais criteriosa, cuida melhor da cientificidade dos trabalhos de pesquisa desenvolvidos na abordagem qualitativa, que não se coaduna com uma postura laissez faire,

\footnotetext{
21 Tomamos a expressão 'abordagem qualitativa' entendendo-a como um caminho metodológico que implica questões de ordem técnica, de método interpretativo e de competência teórica, mais compatível com os fenômenos complexos das ciências sociais, especialmente da educação, cujo objeto, o ser humano, impossibilita a separação entre causas e motivações, conforme afirma Martins (2004).
} 
pois essa decisão determinará escolhas e a organização de etapas em função do que se quer observar e conhecer, na busca pela transcendência do senso comum.

Tal perspectiva pressupõe o rigor do pesquisador na definição dos instrumentos metodológicos, na convicção de que, mesmo com todo cuidado, a pesquisa em educação é um campo movediço e, de forma geral, sofre a influência das atitudes do pesquisador, denunciando os limites da objetividade e da neutralidade nesse tipo de atividade. Portanto, a rigorosidade se faz pela postura ética e pela socialização do processo de investigação, dos enredamentos do caminho que exige um debruçar-se constante sobre a problemática básica e sobre os questionamentos iniciais.

O método, desse modo, manifesta as crenças, os valores e as perspectivas teóricas que caracterizam o pensamento do pesquisador. Por isso, tem a ver com a atitude do pesquisador. A esse respeito Gatti (2002, p. 53) traz o seguinte comentário:

Aí está a questão do método, que não é apenas uma questão de rotina de passos e etapas, de receitas, mas de vivência de um problema, com pertinência e consistência em termos de perspectivas e metas.

Woods (1996, p. 69) acrescenta a essa análise o seguinte pensamento:

O conteúdo da investigação é, desta forma, identificado parcialmente pelos interesses e valores pessoais do investigador, assim como o são um número de escolhas dentro do estudo, como as áreas em que o investigador se vai concentrar, quem vai visitar e com quem falar, o que vai ver e no que vai reparar.

Embora o desenvolvimento da pesquisa se caracterize por uma certa regularidade e sistematização, seu caráter dinâmico, o ambiente educativo, as relações pessoais e institucionais e as muitas realidades que identificam os sujeitos reafirmam uma análise a partir do paradigma qualitativo. Como afirma Oliveira-Formosinho (2002, p. 97):

Os proponentes do paradigma qualitativo [...] assumem que há múltiplas realidades e não uma, cada uma relativa à experiência de quem a constrói, e que, portanto, a pesquisa subjetiva é a única possível. Como conseqüência, todos os estudos são influenciados por valores até um nível indeterminado.

A investigação, assim, esteve ancorada em alguns princípios que buscaram manter a cientificidade e estabelecer uma linha de análise que promovesse o diálogo entre a metodologia, os referencias teóricos e os dados coletados. São eles: 
a- A aproximação do pesquisador com o ambiente natural e os sujeitos da pesquisa;

b- A consideração dos dados coletados num processo de interação entre pesquisadora e coordenadores participantes da pesquisa;

c- Os sentidos que os participantes dão à sua ação é o ponto a ser considerado pelo investigador;

d- O quadro teórico dá base para a análise dos dados, sustentando qualquer abstração construída.

Tais ações somam-se ao conjunto das estratégias que, buscando a construção dos dados, não se descuida do rigor característico do trabalho científico em educação.

Considerando a validade dos resultados e os princípios aqui expostos é que a opção pelos instrumentos de coleta de dados foi sendo bosquejada: a entrevista, a observação, o Grupo Dialogal ${ }^{22}$ e a pesquisa documental. $\mathrm{O}$ aporte para a pluralidade de instrumentos de coletas de dados encontra-se na análise desenvolvida por Denzin e Lincoln (1998 apud OLIVEIRA-FORMOSINHO 2002, p.97). Segundo os autores:

\begin{abstract}
As investigações qualitativas envolvem então o uso intencional de uma variedade de materiais empíricos (estudo de caso, experiência pessoal, introspecção, histórias de vida, entrevistas, observação, textos históricos, interações e textos visuais) que descrevem momentos, problemáticas e significados, tanto rotineiros, quanto não-rotineiros, nas vidas individuais e grupais. Paralelamente, os investigadores qualitativos usam uma vasta gama de métodos inter-relacionados, esperando alcançar uma melhor compreensão do fenômeno estudado.
\end{abstract}

Assim, na natureza multimetódica da pesquisa qualitativa, conforme apresentada por Oliveira-Formosinho (2002), a intenção de garantir o rigor próprio da atividade científica e a complexidade da ação investigativa no espaço escolar favorecem e direcionam a opção pelos instrumentos de coleta de dados.

Como é explicitada por Oliveira-Formosinho, a 'bricolage $e^{23 \text {, }}$ caracteriza esse tipo de investigação que apresenta aspectos que a identificam ora com a etnografia, ora com a investigação-formação Nóvoa (apud CANDAU, 1997, p.61), mas apresenta uma 'fisionomia' própria, talvez de investigação para fazer pensar. Nesse caso, deixando boas questões em ambos os lados: do pesquisador e do informante/participante.

\footnotetext{
22 A ideia do Grupo Dialogal foi desenvolvida na pesquisa de mestrado a partir da concepção do grupo de opinião, principalmente, pela oportunidade de os participantes dialogarem, discutirem, trazerem à tona fatores críticos. A diferenciação entre os dois grupos se dá pela inserção ativa da pesquisadora no grupo, propondo a pauta de discussão e questionando as respostas dadas.
} 
A entrevista de caráter semiestrurado ${ }^{24}$ foi organizada considerando a natureza relacional e de interação que esse instrumento proporciona. No diálogo entre a pesquisadora e o entrevistado, é possível uma intersecção, que passa pelo interesse de ambos: o entrevistado que vive uma prática e tem o saber da experiência, é alguém produtor de um conhecimento - e a pesquisadora - que deseja conhecer e entender a natureza desse saber. Como afirma Woods (1996, p.68),

[...] são necessárias competências especiais para a entrevista, que no seu âmago tem uma determinada pessoa mostrando compreensão e empatia pelo entrevistado. Uma vez que isso tenha se iniciado, é necessário mobilizar outras competências, nomeadamente a escuta ativa, a qual revela ao outro que o estamos a ouvir e a reagir e pontualmente a construir interpretações, com o objectivo de manter o enquadramento interpretativo e de o fazer sentir-se "valorizado".

A entrevista foi realizada com a intenção de colher as impressões dos coordenadores sobre o trabalho com a formação na escola. No entanto, mesmo após a entrevista, foi possível voltar a conversar exclusivamente com as coordenadoras, cuja atividade foi alvo da observação.

Esse colóquio caracterizou-se mais pela socialização das falas dos professores no Grupo Dialogal, quando, então, esses profissionais envolvidos na formação apontam aspectos que rejeitam e acolhem no projeto de formação desenvolvido na unidade. Nesse momento, as falas das coordenadoras caracterizaram-se por certa ponderação sobre as informações socializadas, não demonstrando grandes surpresas em relação às afirmações dos professores, algumas dessas ideias já apontadas pelas próprias coordenadoras na entrevista inicial.

O último encontro com as coordenadoras aconteceu após a socialização feita pela pesquisadora da transcrição das entrevistas e dos relatórios de observação. A intenção, nesse momento, era contribuir com essas profissionais, para a reflexão sobre o seu próprio trabalho, por meio de um olhar externo. Nessa fase, as coordenadoras relataram como intervieram nos grupos, após a ciência dos depoimentos dos professores no Grupo Dialogal, e como esses relatórios possibilitaram enxergar a formação do ângulo de sua própria rotina, antes desconsiderado.

Embora a intenção das entrevistas fosse colher informações que auxiliassem no estabelecimento de certo padrão 'de coincidências' e na formulação das categorias de análise,

23 Bricolage, termo francês que está associado, conforme salienta Oliveira-Formosinho (2002), a uma análise da investigação qualitativa pela sua natureza multimetódica. 
ainda assim, apesar da intersecção entre as percepções colhidas, foi possível perceber diferenças na concepção e no trabalho desses profissionais.

Outro aspecto considerado nas entrevistas e favorecido pela retomada das perguntas foi a valorização dos saberes desses coordenadores que vivem a profissão, compreendendo que os depoimentos constituíam-se em uma elaboração e re-elaboração de uma história do que foi vivido, portanto de uma imagem opaca das situações narradas, cujo colorido fica em função dos aspectos que marcaram essa trajetória. Assim, o narrado não foi o experienciado literalmente, mas uma impressão sobre o ocorrido, mediada também pelas práticas. Szymanski (2004, p.14) aponta nesse processo de interação fatores de ordem emocional intermediados pelos sentidos e pelas crenças dos participantes:

[...] a entrevista também se torna um momento de organização das ideias e de construção de um discurso para um interlocutor, o que já caracteriza o caráter de recorte da experiência e reafirma a situação de interação como geradora de um discurso particularizado. Esse processo interativo complexo tem um caráter reflexivo, num intercâmbio contínuo entre significados e o sistema de crenças e valores, perpassados pelas emoções e sentimentos dos protagonistas.

Era um objetivo que a entrevista semiestruturada se caracterizasse por uma conversa com as coordenadoras sobre a formação desenvolvida nos horários coletivos. A entrevista havia sido planejada de maneira que as pautas da fala das coordenadoras fossem retomadas como elemento de ampliação dos conceitos veiculados e de reflexão sobre o dito, como possibilidade de refazimento do discurso.

Ouvir quatro coordenadoras objetivava buscar pontos em comum entre os participantes de uma mesma atividade profissional, porém considerando que elementos como grupos etários diferentes, tempo na profissão, formação etc seriam fatores intervenientes.

Tais aspectos, quando considerados, estimulam uma análise cuidadosa, evitando-se generalizações precipitadas decorrentes de uma estandardização acrítica, que desconsideram os contextos específicos da atuação de cada profissional e o que a pesquisadora deseja conhecer, sobrepujando as explicações e as respostas.

Essa troca de informações atribuiu um caráter dinâmico à pesquisa, bem como possibilitou elencar elementos, sob a perspectiva do olhar do investigador, que favorecessem a reflexão sobre o trabalho de formação na escola.

$24 \quad$ Segue anexo o roteiro da entrevista semiestruturada. 
A observação direta, in loco, permitiu à pesquisadora aproximar-se dos modos de compreensão dos sujeitos, do discurso delas (as coordenadoras) e de sua configuração na prática. A observação exigiu um foco direcionado para que não fossem perdidos elementos na multiplicidade de estímulos que o contato direto permite. Portanto, o olhar investigativo pairou sobre o coordenador pedagógico no ato de coordenar os processos de formação contínua na escola. Segundo André (1986, p. 26):

\begin{abstract}
A observação direta permite também que o observador chegue mais perto da "perspectiva dos sujeitos", um importante alvo nas abordagens qualitativas. Na medida em que o observador acompanha in loco as experiências diárias dos sujeitos, pode tentar apreender a sua visão de mundo, isto é, o significado que eles atribuem à realidade que os cerca e às suas próprias ações.
\end{abstract}

Ao se introduzir na escola e nos grupos de formação, a pesquisadora não o fez só com o olhar, mas com o corpo e com a mente. Como corpo, ocupa um espaço físico, isso a denunciou como observadora, cuja participação restringiu-se a uma identidade revelada e à socialização dos objetivos da pesquisa, pois não havia a inserção da observadora nas atividades desenvolvidas pelas coordenadoras. No entanto, a mente guardava sigilosa as informações colhidas, cujas análises buscavam referências num conjunto teórico.

A observação e as anotações, fruto desse trabalho, eram feitas a partir de uma posição de afastamento do grupo num recuo, cujos sentidos estavam voltados para as reações frente às propostas da coordenação e do grupo em relação às atividades de formação desenvolvida. Tal postura não significou invisibilidade nem tampouco neutralidade ou a ideia de que a pesquisadora tenha passado despercebida: ela estava lá, e todos sabiam disso.

A observação, num trabalho qualitativo, tem um caráter de vivacidade, pois o objeto observado não se presta à imobilidade, não está sitiado num laboratório e não recebe estímulos do pesquisador para promover qualquer reação. O objeto está circunscrito a um espaço dinâmico, e tanto ele como o espaço/tempo sofrem mudanças constantes, portanto, carregam o sentido do contexto e as limitações do olhar, ainda que atento.

Também há que se considerar que o trabalho do coordenador na escola é sempre uma ação com os outros: alunos, pais, comunidade e professores. Com esses últimos, a sua atuação é ainda mais complexa, porque parte da suas atribuições consiste em trabalhar (articulando, refletindo, analisando) sobre a atividade do professor. O que pressupõe uma observação enviesada, que enxerga no primeiro plano o coordenador, mas alcança os professores participantes do processo de formação. Segundo Gatti (2002, pp. 11 e 12): 
Conhecimentos são sempre relativamente determinados sob certas condições ou circunstâncias, dependendo do momento histórico, de contextos, das teorias, dos métodos, das técnicas que o pesquisador escolhe para trabalhar ou de que dispõe. Portanto, o conhecimento obtido pela pesquisa é um conhecimento situado, vinculado a critérios de escolha e interpretação de dados, qualquer que seja a natureza destes dados.

Assim como o conhecimento, os métodos são determinados em função do tempo, do espaço, das relações, dos contextos da pesquisa e estão, também, em constante re-elaboração.

Nos grupos acompanhados, a presença da pesquisadora criava, no primeiro momento, uma mudança na forma de participação dos envolvidos (coordenadores e professores), que normalmente tornavam-se mais reservados. No entanto, a insistência ${ }^{25}$ e a sistematização desse procedimento acabaram por favorecer a aceitação desse processo de observação, o que significou um afrouxamento da guarda e a permissão para estar junto na formação.

Esse período foi profícuo para uma aproximação do panorama formativo das coordenadoras e dos professores, o que possibilitou entender os sentidos que esses profissionais atribuem às suas ações, especialmente o investimento na formação contínua na escola e exigiu um processo descritivo minucioso e, por vezes, a reconstrução dos diálogos.

O foco dessa atividade, como já indicado, esteve sobre o coordenador pedagógico envolvido com uma parte de suas atribuições, o próprio desenvolvimento da ação formativa. A observação deteve-se na relação entre o coordenador e o grupo, ou seja, em como o coordenador promovia e reagia à participação dos professores e como conduzia as reuniões: quais aspectos valorizava, quais questionava, como favorecia a socialização dos conhecimentos. E simultaneamente nos conteúdos da formação, ou seja, em como os conteúdos atendiam às necessidades formativas elencadas pelos professores, como os problemas da prática eram alvo de reflexão e se os professores sentiam-se confortáveis com a coordenação dos trabalhos.

Focar as ações formativas desenvolvidas pelo coordenador pedagógico propicia luz sobre o profissional e sua atividade, o que não significa que ele sozinho seja o responsável pela eficácia da formação contínua desenvolvida na escola. Existem outros atores nessa trama e não se pode desconsiderar nem o próprio cenário, a escola. Portanto, investigar o trabalho do coordenador na formação contínua é considerar um conjunto de aspectos, como a

25 Durante a pesquisa, foram observados 20 encontros na Escola A e 13, na Escola B. 
participação dos professores, a organização do projeto de formação, o espaço físico adequado à reflexão, a garantia das condições materiais, a relação entre a equipe técnica, dentre outros.

A observação não se caracterizou apenas pelo investimento de um longo tempo na pesquisa empírica. Estar junto com dois grupos durante quase um ano letivo contribuiu para a percepção dos problemas na perspectiva dos sujeitos e as contradições desse espaço.

Como recurso para uma oitiva dos professores envolvidos, a opção foi pelo Grupo Dialogal, pois, no momento da pesquisa havia uma sobreposição do uso do 'lugar', o espaço de formação dos professores tornou-se espaço de reflexão/ investigação sobre a formação (Domingues, 2006). Os aspectos que identificam essa estratégia foram:

- Os professores convidados participavam de um projeto de formação desenvolvido na escola;

- Os Grupos Dialogais, um em cada escola, reuniram-se no espaço institucionalizado para a formação;

-O número de participantes variou entre seis e vinte pessoas;

-As discussões propostas tinham como objetivo mobilizar a discussão e propiciar que os participantes ouvissem diferentes opiniões.

O Grupo Dialogal foi desenvolvido com os professores das duas escolas que participavam da formação nos horários coletivos e constituiu-se basicamente em dois encontros. Neles foram desenvolvidas duas dinâmicas que objetivavam promover uma reflexão sobre a formação contínua desenvolvida na escola, visando colher informações que ajudassem a compreender o trabalho da coordenação pedagógica.

Por se tratar de uma pesquisa que analisa o trabalho do coordenador sobre a formação dos professores, não era possível abandonar os sujeitos-alvo do processo formativo desenvolvido no horário coletivo das escolas. Ouvi-los possibilitou considerar intervenções exógenas e endógenas de um ponto de vista diverso do coordenador, mas diretamente associado ao discurso que se pauta pela ideia de desenvolvimento profissional dos professores.

Assim, tornou-se fundamental a participação dos professores na pesquisa, opinando sobre o projeto de formação contínua da escola e revelando o significado que eles dão à formação centrada na escola e ao trabalho de coordenação nesse processo.

Essa atividade favoreceu a interação do pesquisador com esses participantes, que embora não fossem o alvo da pesquisa, estavam implicados no processo de formação, não só pelo acesso a ele, mas também pela possibilidade de construir com o coordenador esse espaço 
de formação. Ao propor, inicialmente, o desafio de responder sobre os aspectos que desprezariam e reforçariam no projeto de formação da escola, foi possível a eles aproximarem-se de uma lógica diferente daquela do coordenador. Enquanto os professores valorizavam a troca de experiências e a relação pessoal do grupo, ambos aspectos cujo enfoque esteve sobre as interações e a socialização dos saberes pessoais/profissionais, os coordenadores estavam preocupados com a sistematização de um trabalho que atrelava teoria e prática, pautado pelos saberes de agentes externos à escola.

No segundo encontro do Grupo Dialogal, a proposta era refletir sobre uma situação hipotética. Grosso modo, frente a uma possível extinção do horário coletivo, os professores deveriam criar uma argumentação favorável à continuidade da jornada que favorece a formação na escola. Os participantes foram pródigos ao elencar as vantagens de uma jornada estendida para a formação, ou seja, apontaram que favorece o estudo de teorias, o preparo de aulas, a elaboração de projetos coletivos, a busca de soluções para os problemas de sala de aula e da escola, a reflexão sobre a prática, a discussão sobre indisciplina, o diagnóstico do desenvolvimento dos alunos, a atualização profissional e a formação dos professores. Contudo, insistiram também nos aspectos já citados: integração/vínculos entre os docentes e trocas de experiências.

O diálogo nesses grupos e os questionamentos propostos visavam à coleta de dados e uma aproximação da ação do coordenador na perspectiva dos docentes, dando voz a eles para que, ao ouvirem primeiro a si mesmos e depois aos outros, também fossem ouvidos, pela mediação da pesquisadora, pela coordenação da escola.

Embora a investigação tenha sido planejada para possibilitar ao coordenador pedagógico pensar sobre seus próprios caminhos profissionais, isso não se deu de forma impositiva. O foco estava nas percepções da coordenação sobre a sua atuação formativa e, em relação ao professor, no olhar desse outro profissional, sobre a formação contínua desenvolvida pelo coordenador pedagógico.

O Grupo Dialogal foi organizado para dois encontros que somavam aproximadamente quatro horas de trabalho em cada escola. E tinha como princípio o diálogo entre os participantes por meio de uma 'questão problematizadora', que mobilizava a discussão, permitindo a inserção da pesquisadora apontando as contradições das falas dos professores e favorecendo uma retomada do discurso e uma possível reformulação. Essa foi uma opção na tentativa de favorecer um diálogo reflexivo com os docentes, considerando que na entrevista com as coordenadoras essa reflexividade foi prevista. 
Adentrar a escola, seja ela antiga, cujos sujeitos foram se inserindo ao longo do tempo, seja recém-inaugurada, com uma equipe disposta a comprometer-se com a atividade pedagógica, é possível observar seriedade, compromisso e crença na educação pública.

A investigação, no seu aspecto empírico, contribuiu para observar um 'ponto fraco' na organização escolar, que atinge os projetos de formação na escola, ou seja, a descontinuidade pedagógica, fruto de mudanças políticas e administrativas (mudança no quadro de educadores por remoção e doença e em virtude da política educativa assumida pelo sistema). Esse fato ficou evidente no depoimento das coordenadoras que, ao assumir a escola, necessitaram de um tempo para adaptação e posterior atuação. Tempo que marcou a escola com mudanças conceituais, organizacionais e de relação com o conhecimento e entre os profissionais envolvidos.

Diante desse desafio, a opção foi por caminhos que se completam e que procuram identificar os conhecimentos na ação dos coordenadores pedagógicos, assim como conhecer os limites e as possibilidades da prática desse profissional na condução dos projetos de formação na escola.

O projeto metodológico da tese, na perspectiva anunciada, propiciou a entrada da pesquisadora no cotidiano dos projetos de formação na escola favorecendo a observação do trabalho articulado pelas coordenadoras pedagógicas e, também, a oitiva dos sujeitos envolvidos nesse processo formativo.

No decorrer da investigação, outro instrumento para a coleta de dados foi a pesquisa documental. Foram alvo de análise o Estatuto dos Profissionais de Educação do Ensino Municipal de São Paulo, Lei no 11.229/1992, reformulado pela Lei no 11.434 de 1993, pela Lei $n^{\circ} 12.396$ de 1997 e atualmente pela Lei $n^{\circ}$ 14.660/07; os decretos que organizam os

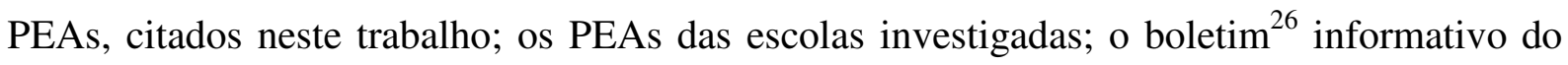
Sindicato dos Profissionais em Educação no Ensino Municipal de São Paulo - SIMPEEM de setembro de 2007; e os documentos de formação publicado pela Rede Municipal de Ensino: Rede em rede: a formação continuada na educação infantil e o Referencial de expectativas para o desenvolvimento da competência leitora e escritora no ciclo II do ensino fundamental.

A pesquisa documental foi importante para caracterizar as situações pesquisadas e, no caso específico desta investigação, trazer para o contexto da pesquisa as ações do sistema de

26 Segue anexa, cópia de parte do boletim do SIMPEEM que aponta para a mudança da denominação do cargo no município de São Paulo. 
ensino (legislações, publicações etc.) que se configuram intervenções nos projetos de formação contínua do docente na escola.

Os documentos constituem-se numa rica fonte de informações, principalmente por apresentar a perspectiva dos gestores das políticas públicas em relação à formação na escola.

Os dados colhidos proporcionaram a caracterização do trabalho das coordenadoras e das escolas e revelaram o processo de desautorização dos projetos das escolas em função de programas generalistas de formação.

\section{As parceiras da pesquisa e as escolas que a sediaram}

Ao eleger a formação contínua na escola e o trabalho do coordenador pedagógico como foco dessa investigação, pretendeu-se lançar luz a um dos aspectos das atribuições desse profissional expresso no regimento das escolas municipais. Segundo Decreto $33.991 / 94^{27}$, entre as muitas atribuições desse profissional, cabe a ele, "participar, juntamente com a Equipe Escolar e o Conselho de Escola, da proposição, definição e elaboração de propostas para o processo de formação permanente, assumindo os encaminhamentos de sua competência". Tal determinação orienta a pesquisa na compreensão dos 'encaminhamentos de competência' do coordenador, considerando sua responsabilidade pela proposição, definição e elaboração da proposta de formação contínua do docente na escola.

A pesquisa foi projetada para a escola porque ela é o locus de trabalho do coordenador pedagógico, onde se configura sua prática de coordenação dos projetos de formação contínua.

A caracterização das escolas envolvidas na investigação toma o cuidado para não identificá-las, porém procura minimamente descrevê-las, por entender que esses aspectos estabelecem variáveis na formação pretendida.

As coordenadoras contatadas são efetivas e os critérios de escolha dessas profissionais foram: a) a existência de um projeto de escola que privilegiasse a formação em serviço; b) coordenadores que estivessem à frente dos projetos de formação de professores no horário coletivo; c) coordenadores que permitissem a observação de seu trabalho durante o desenvolvimento do projeto de formação. 
Os encontros aconteceram na Escola A, às terças-feiras no segundo semestre de 2006 e no primeiro de 2007 e, na Escola B, inicialmente às segundas-feiras em 2006 e, posteriormente, às quintas-feiras em 2007. A mudança ocorreu em virtude de reconfiguração dos horários da escola.

A aproximação das coordenadoras foi relativamente fácil, considerando a predisposição destas em participar da pesquisa. A primeira coordenadora contatada, da Escola B, já era conhecida pela pesquisadora, pois haviam trabalhado juntas no período em que ambas prestavam serviço numa Coordenadoria de Educação ${ }^{28}$ de uma das regiões de São Paulo. No entanto, foi no curso de formação de coordenadores pedagógicos, durante o ano de 2006, que houve o reencontro e a conversa que propiciou o convite para a participação na pesquisa.

As coordenadoras da Escola A foram indicadas pela primeira coordenadora contatada. Ambas também já eram conhecidas em virtude da participação em processo de formação em que haviam se destacado pela postura aberta ao conhecimento, à reflexão e pela integração entre elas. Posteriormente, conversando com as duas coordenadoras, observou-se que a proposta de formação da escola encaixava-se nos critérios desta pesquisa.

A quarta coordenadora entrevistada foi sugerida pela banca de qualificação como um contraponto às atividades de coordenação da formação normalmente realizadas pelas escolas. Então, foram entrevistadas inicialmente três coordenadoras. Dentre estas duas, de escolas diferentes, tornaram-se alvos de observação participante. O número de coordenadoras observadas em sua prática formativa foi limitado para dois, em virtude da falta de tempo da própria pesquisadora para colher e analisar uma grande quantidade de dados.

Assim, após as entrevistas, iniciou-se o processo de observação e de acompanhamento de um grupo na Escola A, à noite, e outro grupo na Escola B, pela manhã. Ficou acordado, com as duas coordenadoras participantes dessa etapa, que, além do período de observação das atividades desenvolvidas no projeto de formação, num outro momento os professores seriam consultados sobre a formação posta em prática na unidade.

$\mathrm{Na}$ apresentação do projeto de pesquisa para as coordenadoras, antes das entrevistas, houve um acordo de sigilo para preservação da fonte dos dados. Tal compromisso constituiuse num contrato verbal entre as coordenadoras pedagógicas entrevistadas e a pesquisadora, e ficou configurado da seguinte forma:

27 O Decreto 33.991/94 dispõe sobre as atribuições do coordenador pedagógico na Rede Municipal de Ensino de São Paulo.

28 Atualmente chamadas de Diretoria Regional de Educação. 
Liberdade para interromper a entrevista a qualquer tempo, não responder alguma questão ou cancelar qualquer encontro de observação;

Permissão das coordenadoras para gravar as entrevistas;

Sigilo absoluto sobre a fonte dos dados, o que implica a não identificação das escolas e das profissionais envolvidas. Os professores seriam identificados por meio de letras do alfabeto e as coordenadoras por pseudônimos;

Possibilidade das coordenadoras lerem o material transcrito e fazer alterações;

Possibilidade de, a qualquer tempo, quer por solicitação da pesquisadora, quer por solicitação das participantes, haver apresentação dos dados já coletados para uma reflexão.

Vale a pena esclarecer que como não foi possível acompanhar todas as coordenadoras entrevistadas, a opção foi por observar as coordenadoras que atuavam em escolas diferentes.

Abaixo, segue a caracterização das coordenadoras a partir das entrevistas. A ênfase será na formação e na experiência profissional. Em alguns aspectos, as falas das próprias coordenadoras serão trazidas.

\subsection{Coordenadora Maria Vitória - a formação como um processo de socialização dos conhecimentos docentes}

A coordenadora Maria Vitória foi a primeira a ser entrevistada e alvo da observação da pesquisadora no horário coletivo de formação. Tem 40 anos e é mãe de dois filhos. Iniciou no magistério em 1982, formando-se em 1985. Tem 18 anos, entre a docência e a coordenação pedagógica, no serviço público. Segundo o seu relato, o ingresso no curso de formação de professores se fez, inicialmente, pela imposição do pai que queria que ela seguisse a mesma profissão da irmã. Apesar disso, concluiu o curso sem nenhuma dificuldade e, posteriormente, optou pela licenciatura em biologia por indicação de algumas colegas. Mesmo considerando que o magistério seria uma atividade de passagem, enquanto buscava uma atividade mais relevante, a profissão foi lhe conquistando:

No começo da minha carreira, eu não encarava o magistério como profissão, eu achava que o salário era tão pequeno, que aquilo não era profissão. Fui trabalhando com a impressão de que algum dia eu descobriria alguma coisa interessante.

Após a formatura, trabalhou como professora de ensino fundamental e na educação de jovens e adultos (EJA), na Rede Municipal de Ensino de São Paulo, e como professora de 
ciências no ensino fundamental II, na Rede Estadual de Ensino, e havia seis anos que trabalhava na coordenação pedagógica da mesma escola.

Logo que assumiu esse cargo, encontrou dificuldades para determinar os limites e as possibilidades de atuação. Segundo ela, os primeiros anos constituíram-se em um processo de construção da sua profissionalidade de coordenadora pedagógica.

Foi envolvendo-se nessa atividade com a ajuda dos pares, outros coordenadores, que Maria Vitória foi criando uma identidade profissional, à medida que, também, estabelecia uma relação com os professores da escola e passava a conhecer a cultura escolar local. Dessa forma, foi aprendendo a trabalhar em parceria, criando, no espaço coletivo de formação, oportunidades de socialização de conhecimentos.

\subsection{A Escola A e a formação contínua coordenada por Maria Vitória}

A escola onde esta coordenadora desenvolve seu trabalho está situada na zona leste da cidade de São Paulo e atende a comunidade em quatro turnos, atendendo a cerca de 2.400 alunos entre crianças, jovens e adultos (EJA). Em 2007, contava com as seguintes salas e turmas por turnos:

Salas e turmas da Escola A

\begin{tabular}{|c|c|c|c|}
\hline TURNOS & SALAS & TURMAS FUND I & TURMAS FUND II \\
\hline $1^{\circ}$ turno & 18 & 09 & 09 \\
\hline $2^{\circ}$ turno & 18 & 13 & 05 \\
\hline $3^{\text {a }}$ turno & 18 & 04 & 14 \\
\hline $4^{\circ}$ turno & 07 & $01($ EJA) & $06($ EJA) \\
\hline
\end{tabular}

Quadro 01: Elaborado a partir do projeto de 2007 da Escola A

Além das salas de aula, a escola tem outros espaços educativos: uma sala de leitura, um laboratório de informática, um anfiteatro, uma sala de vídeo, uma sala de $\mathrm{SAP}^{29}$, uma sala de recuperação paralela, um laboratório de ciências (ainda não estava montado), uma sala de

29 SAP é a sala de apoio pedagógico, que atende aos alunos com dificuldades de aprendizagem fora do seu turno de estudo. $\mathrm{O}$ atendimento é feito por um outro professor que trabalha com um número reduzido de crianças ou jovens. 
arte, uma sala de projeto (Afro + Fanfarra), duas quadras e um espaço coberto para educação física (não é quadra), um pátio interno onde é servido o lanche, uma cozinha, banheiros de alunos e professores, uma sala de professores, uma sala da secretaria, uma sala da direção, um estacionamento para os carros dos professores, uma sala da coordenação e uma sala para o desenvolvimento das atividades referentes à jornada especial integral de formação (JEIF).

A unidade escolar possui o quadro completo da equipe técnica (direção, assistente de direção e duas coordenadoras) e possui quadros de professores, de funcionários de secretaria e agentes escolares bem definidos. É uma escola antiga na região. Toda essa estrutura dava suporte a quatro grupos de JEIF, que possibilitavam a formação contínua sistemática do docente na escola, dividida igualmente entre as duas coordenadoras que assumiam respectivamente um grupo de Leitura e Escrita e outro grupo do projeto "São Paulo é uma escola".

A sala de estudos, no início da pesquisa, era improvisada: um anexo da sala dos professores. Em 2007, após uma reforma, a escola ganhou uma nova sala para reunir os docentes, porém ainda diminuta para atender o número de professores naquele horário coletivo.

Quando o contato foi feito, a diretora da escola mostrou-se favorável à pesquisa e deixou o caminho aberto para o contato com as coordenadoras. Ficou estabelecido que a conversa aconteceria no primeiro semestre de 2006, mas, devido à greve e às férias das duas coordenadoras, só foi possível retomar o contato no segundo semestre, quando a pesquisadora compareceu à escola para formalizar os procedimentos com as profissionais.

Num encontro de cerca 30 minutos, foi possível esclarecer alguns aspectos sobre a pesquisa, quando foram apresentadas as mesmas informações já socializadas com a diretora. Ambas mostraram-se receptivas, colocando-se à disposição da pesquisadora. Foi apontada a necessidade de acompanhamento de um grupo de JEIF, num trabalho de observação da ação da coordenadora e combinado que esse grupo seria o da terça-feira à noite, pois, segundo elas, nesse dia, a formação é menos fragmentada, apenas um projeto é desenvolvido. Uma delas manifestou achar importante a observação nos grupos de JEIF, argumentando que seria bom ter um interlocutor diferente dos professores que pudesse apontar questões para uma reflexão sobre o trabalho da coordenação.

A primeira entrevista aconteceu numa sexta-feira (11/08/2006), dia da semana em que as coordenadoras não atendiam aos grupos de JEI. Nesse dia, foi retomado o contrato verbal estabelecido, tentando-se garantir os aspectos éticos e humanos das relações, procurando-se criar um elo de confiança que possibilitasse o acesso à escola de forma tranquila. 
São dois os projetos de formação desenvolvidos: um relacionado à leitura e escrita, ao Programa de governo Ler e escrever, e o outro, ao programa São Paulo é uma escola ${ }^{30}$. As coordenadoras revezavam-se nos horários coletivos, assumindo projetos formativos diferentes e abrindo possibilidades de comunicação e interação entre os diferentes grupos docentes.

O primeiro encontro com o grupo aconteceu na última semana de agosto. Ele se reunia às segundas, terças e quartas à noite e desenvolvia dois projetos de formação: Projeto de leitura e escrita e o Projeto São Paulo é uma escola. O quadro que segue sintetiza a quantidade de grupos, projetos e participantes da formação. A observação aconteceu uma vez por semana.

Projetos de formação na Escola A e os grupos de professores participantes

\begin{tabular}{|l|c|c|l|l|}
\hline $\begin{array}{c}\mathbf{N}^{\mathbf{0}} \text { de grupos } \\
\text { da escola }\end{array}$ & $\begin{array}{l}\text { GRUPO A } \\
\text { Professores } \\
\text { projetos } \\
\text { Desenvolvidos }\end{array}$ & $\begin{array}{l}\text { GRUPO B } \\
\text { Professores } \\
\text { participantes }\end{array}$ & $\begin{array}{l}\text { GRUPO C } \\
\text { Professores } \\
\text { participantes }\end{array}$ & $\begin{array}{l}\text { GRUPO D } \\
\text { Professores } \\
\text { participantes }\end{array}$ \\
\hline $\begin{array}{l}\text { Projeto de leitura e } \\
\text { escrita }\end{array}$ & 12 & 8 & 8 & 17 \\
\hline Projeto multi-cultural & 11 & 9 & 13 & 18 \\
\hline
\end{tabular}

Quadro 02 : Elaborado a partir do PEA 2007 da Escola A

Os projetos desenvolvidos tinham entre 144 horas-aula, quantidade mínima para ser pontuado, e 152 horas-aula, e foram denominados da mesma forma nos dois períodos observados $^{32}$, final de 2006 e início de 2007.

Inicialmente, a observação foi uma tarefa difícil. A quantidade de pessoas tirava o foco que deveria estar sobre o coordenador. Nos primeiros dias, houve momentos de dispersão, momentos em que a ação do grupo se confundia com a da coordenação. No entanto, essa situação foi superada à medida que os critérios de observação foram construídos.

Durante o processo de observação, ficaram evidentes a organização e o controle que a coordenadora demonstrava sobre o seu trabalho, trazendo sempre um roteiro/plano de ações, que era desenvolvido com os professores e que se constituía numa sequência de atividades de formação. Posteriormente ficou comprovado que essa estratégia sistemática estava

$30 \quad$ São Paulo é uma escola é um programa do governo que visa atender aos alunos, aumentando-lhes o tempo de permanência na escola. Para isso, no primeiro momento, as aulas de informática educativa dos alunos do ensino fundamental e educação física das quatro séries iniciais, que aconteciam dentro do horário da aula, passaram a ser oferecidas fora do horário, bem como outras atividades de cunho cultural e lúdico. Para participar das atividades optativas, os responsáveis devem autorizar a frequência das crianças para além do seu horário de aula. Algumas dessas atividades oferecidas são ministradas por oficineiros.

31 As denominações dos projetos neste trabalho não correspondem exatamente ao nome assumido em cada escola. 
relacionada a um trabalho de formação voltado imediatamente para a prática. Metodologicamente, o grupo trabalhava com a temática da sequência didática, voltada para o desenvolvimento das habilidades de leitura, basicamente por meio da leitura do "Referencial de expectativas para o desenvolvimento da competência leitora e escritora no ciclo II do ensino fundamental", da observação de vídeos de casos exitosos, da elaboração de seqüências didáticas de leituras a serem aplicadas aos alunos ou aos colegas do próprio grupo para uma análise mais apurada e apresentação pelos professores das atividades planejadas. Quando aplicado ao grupo ou elaborado coletivamente, o produto dessa reflexão era comentado pela coordenadora, que tomava como referência o material institucional ${ }^{33}$ para analisar os planos organizados considerando o que foi proposto pelos professores antes da atividade de leitura, os desafios lançados durante ela e o planejado para depois.

A rotina do horário coletivo desse grupo estava organizada da seguinte forma:

-Um breve lanche na entrada;

-Uma leitura compartilhada pela coordenadora ou um colega do grupo, normalmente um texto literário;

-Avisos;

- Retomada das atividades da semana anterior;

- A proposta de cada encontro girava em torno da discussão, ou análise, elaboração, avaliação de uma sequência didática de leitura em duplas;

- Apresentação da síntese elaborada pelas duplas;

- Questionamentos da coordenadora e dos colegas;

- Combinados para o próximo encontro.

O trabalho com a sequência didática ${ }^{34}$, muito comum nos encontros seguintes, procurava envolver os professores de diferentes áreas do conhecimento na elaboração de atividades de leitura e escrita, que normalmente ficavam restritas à disciplina de português. Segundo a coordenadora, insistir por um semestre na temática da sequência didática tinha por objetivo garantir que os professores não passassem somente a planejar sequências de acordo com seus conteúdos, mas pensando no desafio da leitura e escrita.

Foram observadas outras temáticas exploradas nesse espaço, essas também voltadas para a formação, mas em função de dificuldades apontadas pela equipe docente. Uma delas

32 As observações foram organizadas em um quadro, anexo, que registra os acontecimentos tendo como referência os dois critérios elencados, ou seja, a relação entre o coordenador pedagógico e o grupo e os conteúdos da formação.

$33 \quad \mathrm{O}$ material nesse caso era "Referencial de expectativas para o desenvolvimento da competência leitora e escritora no ciclo II do ensino fundamenta”l. 
esteve relacionada à participação da escola em um concurso de matemática. A opção pela participação gerou uma demanda de reflexão no horário coletivo, outro aspecto que foi tema de análise dos professores nesse horário foi a preparação de um 'seminário interno' que buscava discutir com pais, alunos e professores questões relativas à organização da escola e à indisciplina dos alunos. Esse último caso envolveu todos os participantes da JEIF na elaboração de pesquisas a serem aplicadas para toda comunidade escolar (alunos, pais, funcionários, professores, equipe técnica) e na seleção de material teórico para a reflexão, o que impulsionou a leitura de outros textos no horário coletivo.

A coordenadora sempre esteve presente nos horários coletivos: desde o primeiro até o último encontro observado, apresentando o tema objeto de reflexão, opinando ou ampliando aspectos do processo reflexivo. Normalmente, o "Referencial de expectativas para o desenvolvimento da competência leitora e escritora no ciclo II do ensino fundamental" era o material teórico utilizado. A coordenadora entendia que essa dinâmica, que fora trazida em virtude do curso de formação oferecido aos coordenadores, contribuiria para o desenvolvimento de habilidades metodológicas aos professores envolvidos, em prol da melhora da leitura e escrita dos alunos.

\subsection{Coordenadora Maria Stella - a formação como tarefa essencial}

A coordenadora Maria Stella tem 37 anos, é solteira, formou-se no magistério em 1988. Ela ingressou na Rede Municipal de Ensino de São Paulo como professora, em 1991, trabalhando com o ensino fundamental, ciclo I (antigos $1^{\mathrm{a}}$ à $4^{\mathrm{a}}$ séries). Fez o curso de geografia e lecionou geografia no ensino fundamental ciclo II (antigos $5^{\text {a }}$ à $8^{\text {a }}$ séries). Trabalhou como assistente técnico-pedagógico na Rede Estadual de Ensino de São Paulo e ascendeu ao cargo de coordenadora pedagógica, também, na Rede Municipal de Ensino, em 2001, após aprovação em concurso público.

Ela atua na Rede Municipal de Ensino há dezessete anos. Destes, os últimos seis anos foram vivenciados na coordenação pedagógica. Segundo ela, exercer a função de coordenadora, no início, não foi fácil, pois exigiu um conhecimento da realidade local que só é adquirido com o tempo:

\footnotetext{
34 Grosso modo, a sequência didática é uma situação articulada que possui um número planejado de atividades consecutivas, cujo critério de elaboração são os níveis de dificuldades. Lerner (2000) traz uma reflexão sobre sequências de atividades.
} 
[...] então eu prestei concurso e vim para a coordenação. Isso foi em 2001. Aí quando se está dentro da escola, a gente vê que a coisa é um pouco diferente [...], tem-se que tomar um cuidado enorme para não ser engolido pelas outras questões, porque existem as questões cotidianas: é o aluno indisciplinado [...], é uma conversa que precisa ser feita, são papeis burocráticos, porque tem papeis que precisam ser entregues e coisas para serem resolvidas.

Relata que fez o magistério e, logo que terminou, foi trabalhar numa escola de educação infantil particular com crianças bem pequenas. Durante seu período de formação na universidade, no curso de licenciatura em geografia, ingressou na Rede Municipal de Ensino, trabalhando com crianças do ensino fundamental ciclo I. Em 1992, passou a trabalhar também na Rede Estadual de Ensino, onde vivenciou a experiência de trabalhar na Diretoria de Ensino, mais especificamente na oficina pedagógica, como Assistente Técnico Pedagógico (ATP) na área de geografia. Nesse tempo, chamou-lhe a atenção a forma como o trabalho naquele espaço era articulado: os profissionais ali discutiam, planejavam reuniões e faziam intervenções em salas de aceleração. Essa experiência foi a base sobre a qual construiu suas ideias sobre o trabalho na coordenação pedagógica.

Quanto às atividades relativas à função da coordenação, ela afirma que existe uma profusão de trabalho na escola e, por vezes, em virtude de solicitações externas, um aumento na demanda de trabalho, o que acarreta um atropelo nas atividades desenvolvidas, porém o seu olhar mantém-se, principalmente, na formação contínua nos horários coletivos:

Então o ideal, aquilo pelo qual a gente luta, é a priorização da formação, mas isso é um processo. Eu percebo que hoje eu consigo priorizar mais do que no início.

A reflexão sobre a formação inicial e a contínua do coordenador trouxe à tona uma consciência da pouca contribuição do curso de formação inicial e a busca por uma identidade profissional do coordenador:

[...] na formação, eu não tive nada que me ajudasse a desenvolver a função, então, acaba sendo um pouco de construção empírica, no dia-a-dia, nós chegamos e descobrimos as demandas. Por isso, comentei que no começo nós nos perdíamos um pouco [...], porque estávamos desfocadas.

A entrevista possibilitou estabelecer uma linha crescente entre o início na atividade de coordenação pedagógica e a situação atual da coordenadora, revelando, segundo o depoimento, um desenvolvimento profissional no decorrer dos anos. Embora tenha relatado 
um começo difícil, de inseguranças e desafios, naquele momento, mostrava-se uma pessoa mais segura da natureza de sua função.

A coordenadora Maria Stella trabalha na mesma unidade que a coordenadora Maria Vitória, porém não foi possível, em virtude da falta de tempo, acompanhar o trabalho dessa profissional nos grupos de JEIF.

\subsection{Coordenadora Maria Leda - a formação para a mudança profissional}

A coordenadora Maria Leda tem 40 anos, é casada e mãe de uma menina. Formou-se no magistério em 1987. Trabalha nessa escola há quatro anos, quando assumiu a coordenação após a remoção de outra unidade. Trabalhou de 2002 a 2005 em órgãos intermediários da Secretaria Municipal de Educação, período em que ficou afastada da coordenação pedagógica. Sobre o começo sua experiência profissional relata as dificuldades do trabalho de coordenar uma escola de ensino fundamental, em virtude de toda sua experiência em educação ter sido em outro nível de ensino.

Trabalhou na Rede Estadual de Educação como professor Admitido em Caráter Temporário (ACT), durante um período curto: três meses. Deixou as aulas na rede estadual quando ingressou na prefeitura como professor substituto na educação infantil e no ensino fundamental. Anos depois, prestou concurso e se efetivou como professor de educação infantil. Em 1997, inscreveu-se no concurso de coordenador pedagógico e ingressou no cargo em 1998. Foram 24 anos de trabalho no ensino público e a maioria deles na educação infantil.

Em relato sobre a formação inicial para o trabalho na coordenação pedagógica, afirmou não ter tido contribuição significativa do curso de complementação pedagógica e que, no seu ingresso como coordenadora pedagógica, enfrentou dificuldades pela inexperiência e pelas especificidades do trabalho no ensino fundamental, nível de ensino em que teve que atuar nessa etapa da carreira. Conforme ela mesma aponta:

Faz 20 anos que eu trabalho na prefeitura, sempre na educação infantil. Minha primeira experiência como coordenadora foi numa escola de ensino fundamental [...] e uma das partes mais difíceis da coordenação no ensino fundamental era o conselho de classe. Eu não conseguia entender e me admirava com algumas coisas básicas, por exemplo, o professor não conhecer o aluno, não lembrar quem era quem [...]. Nossa, foi difícil, na verdade, fiquei observando tentando entender o trabalho. A formação do 
coordenador deveria considerar as especificidades da função em suas diferentes instâncias.

Coordenar a formação no início foi, segundo a própria coordenadora, um exercício de aprendizagem e descobertas que só foi possível pelo apoio das pessoas, pela observação sistemática do trabalho, pois de imediato teve que coordenar um projeto do qual não participara da elaboração, além de mediar conflitos entre a escola e a supervisão.

Refletindo sobre o trabalho, a coordenadora Maria Leda aponta a necessidade e a importância da autoridade do coordenador na atividade de articular o trabalho pedagógico na escola: "Eu acho que o coordenador, querendo ou não, tem uma liderança na escola. Se não tem, deveria ter, pois é impossível organizar um grupo se você não for um líder”.

Sobre os processos de desenvolvimento profissional docente na escola, a coordenadora relata a crença numa formação crítica que possibilite ao professor pensar a sua prática pedagógica contextualizada num período histórico e político:

[...] tem muitos professores que têm uma ideia equivocada sobre a educação infantil. Mesmo atuando nessa área, ele quer fazer o trabalho como se estivesse no ensino fundamental. Ele não se vê na educação infantil, ele se vê como professor de leitura e escrita e acaba escolarizando essa criança [...], então o que a gente mais faz aqui é refletir sobre a própria prática [...], tudo isso vira nossa formação. Se eu não tivesse sensibilidade, eles iriam continuar reproduzindo esses valores, que não iriam para a discussão.

A coordenadora Maria Leda atendeu ao pedido de entrevista e de observação de sua prática, abrindo as portas da escola para a pesquisa.

\subsection{A Escola B - e a formação contínua coordenada por Maria Leda}

A coordenadora Maria Leda desenvolve seu trabalho numa escola de educação infantil, também na zona leste da cidade de São Paulo, que atendia crianças na idade entre 03 anos e 11 meses até 5 anos e 11 meses.

Salas e turmas da Escola B

\begin{tabular}{|c|c|c|}
\hline TURNOS & SALAS & TURMAS DE EDUCAÇÃO INFATIL \\
\hline $1^{\circ}$ turno & 09 & 09 \\
\hline
\end{tabular}




\begin{tabular}{|c|c|c|}
\hline $2^{\text {o }}$ turno & 09 & 09 \\
\hline $3^{\mathrm{a}}$ turno & 09 & 09 \\
\hline
\end{tabular}

Quadro 03: Elaborado a partir do projeto de 2007 da Escola B

Além das salas de aula, a escola conta com outros espaços educativos: uma brinquedoteca; um pátio interno onde são servidos para as crianças o café da manhã, o lanche da tarde e o almoço; uma cozinha; uma área externa onde se localiza o parque; um estacionamento para os carros dos professores; uma sala de secretaria; uma sala da direção; uma sala da coordenação; uma sala de professores, usada, também, para o desenvolvimento das atividades de formação do docente no horário coletivo; banheiros para alunos e professores.

A sala onde acontecia o projeto de formação era, também, a sala dos professores, o que gerava certa movimentação nos horários de intervalo, pois os professores em formação dividiam o espaço com os outros que aguardavam o término do intervalo.

A escola tinha três grupos de JEIF coordenados por uma única coordenadora e funcionava em três turnos, atendendo cerca de 900 crianças.

Com a coordenadora Maria Leda, o contato foi feito durante um encontro de formação e, como ela se mostrou interessada, foi marcado um dia para o projeto de pesquisa ser apresentado à diretora da escola.

Entre a coordenadora e a diretora, havia um 'clima de afinidade' que possibilitou de forma bastante confortável à pesquisadora expor suas intenções, esclarecendo aspectos da pesquisa e os relacionados às questões éticas, que em nada diferiram do acordado entre as demais coordenadoras participantes.

Nessa ocasião, foi marcada a entrevista que aconteceu numa segunda-feira, dia em que a coordenadora não atendia aos grupos de JEIF. Após a entrevista, ficou combinado que o grupo C seria o acompanhado. Este se reunia no horário das $15 \mathrm{~h} 05$ às $17 \mathrm{~h} 20$, conforme a organização do ano de 2006. No ano seguinte, o grupo A foi o alvo da observação e as reuniões eram entre $8 \mathrm{~h} 10$ e 10h45, isso em virtude da supressão do horário do ano anterior.

\section{Projetos de formação na Escola B e os grupos de professores participantes}

\begin{tabular}{|l|c|c|c|}
\hline $\begin{array}{c}\mathbf{N}^{\circ} \text { de grupos } \\
\text { da escola }\end{array}$ & $\begin{array}{l}\text { GRUPO A } \\
\text { Professores } \\
\text { participantes }\end{array}$ & $\begin{array}{l}\text { GRUPO B } \\
\text { Professores } \\
\text { participantes }\end{array}$ & $\begin{array}{l}\text { GRUPO C } \\
\text { Professores } \\
\text { participantes }\end{array}$ \\
\hline $\begin{array}{l}\text { Projeto sobre o prazer na } \\
\text { leitura }\end{array}$ & 05 & 05 & 04 \\
\hline Projeto sobre sexualidade & 05 & 05 & 04 \\
\hline
\end{tabular}




\begin{tabular}{|l|l|l|l|}
\hline infantil & & \\
\hline
\end{tabular}

Quadro 04 : Elaborado a partir do PEA 2007 da Escola B

No primeiro encontro de observação na escola de educação infantil, no início das discussões, a pesquisadora foi apresentada pela coordenadora. As professoras, na ocasião seis, estavam na sala de estudos ou de JEIF, sentadas em volta de uma mesa retangular. A sala tinha dimensões pequenas, impossibilitando, por exemplo, que as pessoas circulassem por ela. Nesse primeiro dia, foi observado que a coordenadora falava mais do que os professores, situação que se repetiu nos demais encontros.

A dinâmica usada nas reuniões consistia, normalmente, na leitura de textos teóricos e de relatos de prática ou apresentação de um vídeo sobre uma prática elaborada, relativa à temática tratada, que eram acompanhadas pelos professores. Posteriormente, junto com a coordenadora, faziam análises, comentavam, davam opiniões, partilhavam experiências profissionais e refletiam sobre o narrado e sua própria prática.

No entanto, um fato chamou a atenção. Durante o primeiro semestre de observação da formação desenvolvida, a temática da formação ficou em torno do estudo dos 'cantos de atividades' na educação infantil. Esse assunto que tomou boa parte de tempo dos encontros de formação não se encontrava expresso no projeto de formação da unidade que tinha como mote o prazer da leitura. O tema desenvolvido era produto de um curso de formação de que a coordenadora participava, que, diga-se, optou por fazê-lo considerando o assunto tratado pertinente com as necessidades da escola.

No ano seguinte, os projetos de formação, que agora eram dois, abordavam como temática o prazer da leitura e a sexualidade infantil, aspectos esses apontados pelos professores e pela coordenação como proposição para a formação naquele ano. Entretanto, nos encontros acompanhados, os temas giravam em torno do brincar na educação infantil, voltando a estabelecer uma relação com os cantos de atividades e a importância do registro do professor na avaliação do trabalho desenvolvido. Ambos os temas também foram pautas da formação do coordenador.

\subsection{A coordenadora Maria Augusta - a formação numa perspectiva libertadora}

A coordenadora Maria Augusta foi a última coordenadora a ser entrevistada. Com 67 anos, Maria Augusta milita na educação há 40 anos. Iniciou sua formação no curso normal no 
interior de Minas Gerais e veio para São Paulo para fazer Pedagogia, cursando depois o mestrado e o doutorado. No início da carreira em São Paulo, como seu diploma de magistério não era aceito nessa capital, precisando ser revalidado com mais um ano de estudos, optou por trabalhar em uma escola particular, primeiro como professora da educação infantil, com crianças de cinco anos, depois, como professora do ensino fundamental. Posteriormente, lecionou no magistério as disciplinas de didática e de metodologia e prática de ensino, transferindo-se mais tarde para a universidade, onde lecionou as mesmas disciplinas. Foi coordenadora pedagógica em escola particular, função ocupada por indicação do grupo de professoras da escola em que trabalhava.

Em 1989, compôs, por indicação do Professor Paulo Freire, o quadro de assessores na Secretaria Municipal de Educação de São Paulo, trabalhando até o final da gestão do Partido dos Trabalhadores (PT), posteriormente, como não pertencia à carreira do magistério na rede municipal, desligou-se do vínculo com o serviço público.

Em relação à sua formação inicial para o exercício do cargo de coordenador pedagógico, faz a mesma análise que as demais coordenadoras. Segundo Maria Augusta, a formação inicial privilegiou a preparação para o trabalho na docência e não para o exercício da coordenação pedagógica. Esses saberes foram desenvolvidos na coordenação, no acompanhamento e na orientação dos estágios para a formação de professores.

Como desejava muito trabalhar na escola pública, conforme depoimento da própria coordenadora, em 1995 participou de um concurso público para provimento do cargo de coordenador pedagógico. Aprovada no concurso, ingressou na rede como coordenadora, começando a trabalhar nessa função em janeiro de 1996.

Ao relatar suas dificuldades iniciais como coordenadora pedagógica numa escola da Rede Municipal de Ensino de São Paulo, ressalta que não encontrou respaldo na avaliação da escola - elaborada no ano anterior para organizar o trabalho de início de ano - e na diretora - cuja recepção foi decepcionante, pois não estava interessada no trabalho pedagógico da escola. Observou, logo de início, uma discrepância na concepção pedagógica da unidade escolar:

A escola estava um caos, os alunos não sabiam ler [...]. No final daquele ano, nós combinamos um tipo de avaliação da escola que organizamos com todos os professores de todos os períodos e trouxemos uma crítica muito forte à administração da escola, foi um retrato da escola [...]. Quando o diretor (novo) chegou, no ano seguinte, em janeiro, no primeiro encontro com ele, nós colocamos na mão dele a avaliação. Ele fala até hoje que tirou da avaliação a sua proposta para a direção [...], essa avaliação trouxe toda a retaguarda para o projeto pedagógico. 
Em relação ao projeto de formação da escola, não o considera desvinculado do projeto político-pedagógico e de uma reflexão coletiva, de fato, entende-o como um braço que concretiza as demandas do projeto político-pedagógico:

Como tinha três ciclos, fomos desmembrando a questão da cidadania como temáticas para cada ciclo, que pudessem se articular e aí foi uma coisa muito legal, porque no ciclo um foi "Leitura e escrita como direito", isso foi de uma felicidade incrível, porque quando começamos a discutir isso com os professores, eles foram entendendo que a questão do ensino da leitura e da escrita não é só decodificar, é uma questão de cidadania mesmo, com significado muito maior. Então, a necessidade da formação saltou, apareceu, e depois no ciclo dois, o tema "era viver com dignidade". Isso também foi muito forte e estava muito presente, então todos os outros projetos vieram no bojo dessas coisas todas. [...] quando escrevemos o texto do Projeto PolíticoPedagógico com o tema cidadania, já colocamos um único PEA, mais relacionado com a formação do educador. [...] o educador vai discutindo, vai planejando, vai se formando para ir dando concretude para esse projeto, o PPP.

A escola em que trabalha a coordenadora Maria Augusta fica na região sul do município de São Paulo. Apesar de ser uma escola de periferia, estava bastante organizada e limpa. Os alunos do ensino regular são filhos de trabalhadores que têm sua residência na região e os alunos do noturno (EJA) são trabalhadores que não concluíram a escolaridade no tempo previsto.

A coordenadora está na escola há 13 anos e o diretor, há 11. Na escola, há vários projetos e festas que envolvem a comunidade escolar (professores e alunos) sempre no sentido de valorizá-los.

A escola tem uma característica que a distingue da maioria no que se refere à organização dos processos de formação. Seu projeto formativo é planejado em conjunto com algumas escolas da região (seis escolas) que abraçaram a ideia de uma 'formação em rede'. As escolas se uniram para otimizar o uso do dinheiro público na contratação de assessorias ou parceiros na formação, juntas podem elaborar projetos formativos, o que, se estivessem isoladas, seria impossível. Assim, as coordenadoras envolvidas, todo início de ano, organizam suas equipes para pensarem juntas projetos formativos interescolares, promovendo a reflexão e o debate coletivo para além dos muros da própria escola. Também, incentivam a produção de escrita dos professores participantes, por meio de uma publicação anual. O PEA é um esforço de congregar essas construções.

Essa organização diferenciada tem, principalmente na coordenadora Maria Augusta, uma referência, em virtude da sua experiência na condução de projetos distintos e de seu 
trânsito na universidade, o que possibilita que os formadores que participam dos cursos que compõem um dos braços do projeto formativo sejam oriundos das universidades, isso de alguma forma incentiva a participação dos professores.

Além disso, Maria Augusta é uma das organizadoras da revista e dos livros publicados pelas escolas que trazem as contribuições de pesquisadores e buscam socializar o trabalho docente e a reflexão desses profissionais sobre a ação.

\section{Alguns nexos entre entrevista, observação e Grupo Dialogal}

Os projetos Especiais de Ação (PEAs) coordenados por coordenadoras Maria Vitória, Maria Stella, Maria Leda, Maria Augusta, grosso modo, inscrevem-se na modalidade de formação permanente do educador, pautada pela ideia de melhoria do ensino oferecido aos alunos, para garantia da aprendizagem e da formação de qualidade a todas as crianças das escolas.

No entanto, foi possível perceber algumas peculiaridades entre as escolas e seus projetos de formação (PEAs), produto da especificidade de cada espaço educativo. Na Escola A, onde trabalham as coordenadoras Maria Vitória e Maria Stella, existem dois PEAs, um que procura atender às determinações oficiais em relação à leitura e à escrita e outro que visa dar continuidade aos projetos já inseridos na cultura de formação da unidade. Na Escola B, na qual trabalha a coordenadora Maria Leda, também existem dois PEAs, um deles sobre sexualidade infantil e o outro sobre a organização do espaço pedagógico da unidade, essa última demanda partiu da avaliação dos professores, mas recebe assessoria externa por meio de um curso de formação contínua do coordenador pedagógico.

O PEA desenvolvido na escola onde trabalha a coordenadora Maria Augusta tem uma característica especial, pois ele é desenvolvido nas 144 horas-aula mínimas com reuniões semanais de 4 horas-aula que obedecem à seguinte rotina: reflexão sobre a prática, leitura e discussão de textos, troca de experiência, planejamento de atividades, análise e avaliação de materiais, pesquisa/leitura/aprofundamento de projetos de trabalho com alunos. Fazem parte desse projeto os cursos de que os professores participam durante o ano, fora do horário de trabalho, mas que foram organizados a partir de uma integração entre as escolas da região, após terem sido ouvidos os professores. Esses cursos acontecem na própria escola ou nas 
escolas do entorno que também participam do projeto, aos sábados ou durante a semana em horários alternativos. Nesse último caso, as escolas envolvidas são responsáveis pela produção de um livro e uma revista por ano e o projeto é desenvolvido dessa forma há 10 anos.

Entrar na escola como pesquisadora, sem ter saído dela como profissional da educação, exigiu um afastamento que não foi uma negação dos diversos papéis assumidos, mas uma necessidade de concentrar-se nesse outro, vivenciando todas as questões que a pesquisa favorecia.

Nesse processo, surgiram dúvidas sobre quais seriam as melhores técnicas de coleta de dados, de como incluir os sujeitos participantes, dando-lhes voz e de como favorecer a descoberta das contradições da prática institucional da coordenação. Os participantes da pesquisa - coordenadores e professores - foram generosos em suas contribuições. As coordenadoras entrevistadas mostraram boa vontade, embora todas elas estivessem sobrecarregadas de serviço.

Os professores que, inicialmente, pareciam desconfiados da presença da pesquisadora, durante o processo de observação, tornaram-se informantes preciosos no desenvolvimento do Grupo Dialogal, aceitando o desafio de pensar a formação vivida no espaço escolar. Seus depoimentos manifestam a consciência da manipulação do espaço de formação na escola, que fere a autonomia de seus agentes na elaboração dos projetos mais autônomos em nível local.

Durante a observação dos trabalhos de formação desenvolvidos na JEIF, não foi possível fazer uso de gravação em áudio, mas um registro sob a forma de um diário. O fato de não serem gravados os momentos de observação favoreceu a criação de confiança entre os participantes e a pesquisadora, o que possibilitou a gravação dos encontros no Grupo Dialogal.

Propor o grupo dialogal foi algo muito importante porque a manifestação dos professores sobre o projeto de formação na escola revelou uma insatisfação escondida por trás da execução de tarefas que mais deformavam do que formavam. Nesse aspecto, as dinâmicas tiveram um papel catalisador das contradições nos grupos de JEIF e das ideias sobre formação contínua centrada na escola.

Dúvidas e preocupações em relação à gravação, às entrevistas, ao grupo dialogal, à forma de observação foram aos poucos debeladas, à medida que a pergunta da pesquisa parecia sobressair-se.

Na pesquisa, ao mesmo tempo em que se percebia a 'dedicação' das coordenadoras e a inquietação dos professores, procurava-se, na intersecção da atuação desses dois profissionais, um elo que contribuísse para o desvelamento dos significados da formação centrada na escola. 
No desenrolar da pesquisa, a suspeita de que a ideia de formação na escola estava diretamente associada à revisão de práticas de ensino foi ficando mais forte. A formação assumia, então, um caráter de atuação sobre a prática, principalmente de alteração de metodologias. Esse aspecto foi reforçado pela contradição entre algumas práticas de formação e o discurso nas entrevistas.

No Capítulo II, a seguir, encontra-se um breve resgate da origem da coordenação pedagógica na Rede Municipal de Ensino de São Paulo, que acompanham as mudanças históricas que promotoras das alterações nessa função. Também apresenta uma análise do processo de formação inicial e contínua do coordenador pedagógico. O intuito é o de contextualizar essa ação profissional, cuja análise passa a ser desenvolvida a partir dos processos formativos vivenciados por esses profissionais. 


\section{A COORDENAÇÃO PEDAGÓGICA, UMA TRAJETÓRIA PROFISSIONAL EM CONSTRUÇÃO}

Se o conhecimento é relativo à história e à sociedade, ele não é neutro, todo conhecimento está úmido de situações histórico-sociais; não há conhecimento absolutamente puro, sem nódoa. 


\section{Todo conhecimento está impregnado de história e sociedade, portanto, de mudança cultural.}

Mário Sergio Cortella

Se, como relata Cortella na epígrafe, o conhecimento está impregnado de história, o/a cargo/função de coordenador pedagógico, por se constituir num tempo dinâmico, foi acrescido(a) de contornos específicos, só explicado por essa imersão no processo histórico. Sendo assim, a coordenação pedagógica vivenciada no século XXI é uma recriação daquela primeira, com demandas outras, geradas no tempo presente. A fluidez desse tempo traz novas exigências, novos modos de ser, novas demandas, outra perspectiva de acompanhamento do trabalho pedagógico na escola, esta emprenhada de conhecimento e história, que vai 'recaracterizando' o coordenador pedagógico e propiciando que ele se estabeleça como um profissional a serviço da organização do trabalho pedagógico e da formação contínua do docente na escola.

Este capítulo apresenta uma análise da formação do coordenador pedagógico e aborda a trajetória da criação desse cargo na rede municipal de ensino de São Paulo. Trata de como os coordenadores pedagógicos têm buscado e organizado sua formação profissional, em virtude das atribuições da coordenação pedagógica, especialmente com relação ao acompanhamento dos projetos que visam ao desenvolvimento profissional docente na escola. Procura ainda situar a criação do cargo de coordenador pedagógico na Rede Municipal de Ensino de São Paulo, mostrando como sua regulamentação é acompanhada por um processo de cerceamento da ação deste profissional. Por fim, frente às discussões acadêmicas que indicam a escola como locus da formação contínua do docente, apresenta uma análise que objetiva localizar historicamente esse profissional e a transformação de sua ação no decorrer do tempo, ajudando a explicar seu papel atual na formação contínua na escola.

\section{O início da trajetória da coordenação pedagógica}


O 'cargo' de coordenador pedagógico foi criado na década de 1980, na Rede Municipal de Ensino, em alguns estados e em alguns outros municípios brasileiros, acompanhando as mudanças sociais e políticas da época ${ }^{35}$.

Parte da tarefa por ele exercida, como nos mostra a história e a legislação da educação brasileira, esteve de alguma forma prenunciada no sistema escolar, associada a outras funções e outros cargos dentro do organograma educacional da época.

Salvador (2000) localiza os antecedentes da coordenação pedagógica no século XII, na história da inspeção escolar, no período confessional, em que a influência religiosa era intensa, mais precisamente nas escolas paroquiais na pessoa dos bispos que as supervisionavam e, posteriormente, com o aumento do número das escolas confessionais, a inspeção foi delegada ao mestre-escola ou escolástico que tinha por tarefa acompanhar as atividades nas instituições e até conceder o direito de ensinar.

Com o declínio da influência da igreja, o desenvolvimento da indústria e do comércio e a lenta ascensão da burguesia, a municipalidade passa a assumir cada vez mais responsabilidades em relação à fiscalização das escolas. Por volta do século XVIII, surge a figura do inspetor escolar público. Segundo a autora, à medida que o Estado assume as responsabilidades com a escola, a inspeção escolar apropria-se de um aspecto fiscalizador, o que virá a caracterizar a supervisão nos períodos subsequentes.

O Brasil, por ocasião de sua colonização, não acompanhou o desenvolvimento europeu e durante duzentos e dez anos o ensino foi atrelado à Companhia de Jesus e os aspectos administrativos e pedagógicos foram organizados conforme os preceitos das escolas jesuítas. Com a expulsão dos jesuítas em 1759, e mesmo com a vinda da família real ao Brasil, houve demora na organização do sistema escolar. As escolas vão sendo criadas de acordo com a densidade demográfica, porém de modo precário quanto ao corpo docente e à inspeção.

Na segunda metade do século XIX, conforme aponta Salvador (2000), São Paulo foi se destacando das outras províncias pela organização e regulamentação da instrução pública, que culminou com a criação do cargo de Inspetor de Distrito em 1868. Com a República e a modificação do Conselho Superior, criou-se o cargo de Inspetor Escolar. Posteriormente, em 1897, extingue-se o Conselho Superior e gera-se a Inspetoria Geral na capital que continuou

35 Segundo Garcia (2003), a década de 1980 foi profícua em reformas educativas no Brasil e no mundo. No Brasil a tônica dessas reformas estava na melhoria da qualidade de ensino, na diminuição da repetência e da evasão escolar. Esse período coincidiu com abertura política do país, com a divulgação de pesquisas educacionais, com o acesso a uma ampla bibliografia internacional, com a dinamização das ações de entidades educacionais e com amplos debates sobre educação. 
sendo auxiliada por Inspetores Escolares. As escolas municipais eram fiscalizadas pelos Inspetores Municipais, cuja função tinha ênfase administrativa.

Já no século XX, o Estatuto dos Funcionários Públicos (1941) prevê o provimento de cargos para diretor, para inspetor escolar e para delegado escolar por meio de provas e títulos. Os cargos de diretor eram preenchidos dentre os professores com três anos de experiência; os de inspetor, por concurso de títulos entre os diretores e os de delegado, nomeados por concurso de títulos entre os inspetores.

Fusari (1997) relata que os inspetores escolares do início do século XX, quando havia oportunidade, necessidade e competência, realizavam um trabalho de formação dos educadores em serviço. Nessa perspectiva, 'os inspetores' podem ser tomados como os precursores dos coordenadores pedagógicos atuais. Fusari (1997, p. 52) provoca-nos essa reflexão, quando afirma:

[...] dentro da conjuntura da época, [os inspetores] exerciam e promoviam o aperfeiçoamento dos educadores em serviço por meio de conselhos aos jovens professores e também aos mais experientes, de aulas de demonstração, de orientação metodológica e sugestão de material colhido em outras escolas por eles inspecionadas.

No final dos anos 1950 e durante os anos de 1960, segundo Souza (2005), a formação do professor em serviço estava pautada no suprimento das falhas da formação inicial. Neste sentido, eram oferecidos cursos, palestras e reuniões visando ao aperfeiçoamento docente. Neste período, também, a ênfase da formação estava no treinamento nos domínios de técnicas, na reprodução e na repetição.

Com as transformações políticas e econômicas da década de $1950^{36}$ e o Plano de Assistência Brasileiro-Americana no Ensino Elementar - PABAEE, surge a supervisão escolar, fato que coincide com a criação das habilitações em Pedagogia (1969), dentre elas a de Supervisão Escolar. Com a posterior integração das concepções e funções da inspeção e da supervisão, feita pela Lei de Diretrizes e Bases da Educação nacional 5692/71, o supervisor passa a assumir uma função fiscalizadora do sistema, bem como a de orientação pedagógica.

Estudos sobre o tema (FUSARI, 1997; GARCIA, 1995; SALVADOR, 2000) identificam, mesmo que de forma implícita, certa coincidência no exercício da função e na promoção do desenvolvimento profissional da equipe escolar, entre as ações do supervisor

\footnotetext{
36 No final da década de 1950, assume o governo do país o presidente Juscelino Kubitscheck de Oliveira, que propõe um modelo nacional desenvolvimentista, investindo no crescimento industrial. O lema era: crescer cinquenta anos em apenas cinco.
} 
escolar e o coordenador pedagógico. Sendo que o primeiro trabalhava na articulação entre as dimensões administrativas e pedagógicas e o segundo passou a trabalhar na relação pedagógica na escola entre as dimensões da organização escolar para aprendizagem dos alunos e, grosso modo, no acompanhamento da ação pedagógica dos docentes.

De algum modo, o sistema sempre criou uma forma de acomodar, entre as muitas tarefas desenvolvidas pelos profissionais da Educação (inspetores, supervisores, diretores, professores), atividades relativas à coordenação pedagógica que, por algum tempo, foi exercida genericamente por diversos educadores.

Essa situação ainda é muito difusa em muitos estados e municípios brasileiros em que o supervisor é tomado por coordenador e vice-versa, tal o grau de imbricamento encontrado entre as duas funções no que diz respeito à formação contínua na escola. Contudo, em alguns estados e municípios, as atribuições desses profissionais parecem estar bem delineadas. Existe a figura do supervisor escolar, que exerce a função ou o cargo de supervisor do sistema, e o coordenador pedagógico, que desempenha a função ou o cargo nas unidades escolares. Vale ainda destacar que, pela complexidade dos processos de formação, eles acontecem, por vezes, independente da ação dos coordenadores e podem se dar de forma sistemática ou fluida, dependendo de características de natureza sócio-histórica dos equipamentos educativos, dos conhecimentos e das relações estabelecidas pelos profissionais que neles atuam.

Assim, é possível admitir que a formação na escola ocorre o tempo todo, nas conversas nos corredores, antes da entrada na sala de aula, na sala dos professores, durante o intervalo, na leitura de um livro, nas conversas informais e formais e, ainda, pode organizar-se como algo sistemático, pensado e elaborado para atingir determinado fim (Domingues, 2004) e, mais, como fruto de um processo reflexivo dos próprios educadores que, por conhecerem as demandas escolares, tornam-se capazes de propor e organizar a própria formação.

O coordenador pedagógico é o educador que, fazendo parte desse processo reflexivo de construção de uma identidade formativa, reflexo do Projeto Político Pedagógico e do currículo adotado pela unidade, é também responsável, na atualidade, pela coordenação de projetos de formação do docente na escola.

Não se trata de desconsiderar o valor da equipe técnica da escola (diretor e assistente de diretor) ou da supervisão escolar, pois todos têm um papel importante na organização de tais processos formativos. Porém, no que tange ao acompanhamento desses projetos, o coordenador pedagógico, ou o educador que assume tal função, torna-se aquele que responde pelo bom andamento do trabalho. 
Conforme já ressaltamos, o presente estudo focará o coordenador pedagógico na gestão do espaço formador na escola, tendo como referência o desenvolvimento dessa função na história da educação no município de São Paulo. Propõe-se, portanto, que a atividade do coordenador pedagógico, como a de toda que faça parte do trabalho educativo, é uma ação política que pressupõe escolhas e clareza das concepções que a norteiam.

O papel do coordenador pedagógico, no contexto desse movimento histórico, vem sendo ressignificado e sua função cada vez mais associada à formação contínua do docente na escola. Na década de 1980, as principais questões educativas diziam respeito à melhoria da qualidade do ensino com a diminuição da repetência e da evasão escolar. Aquela década, calcada por um movimento pós-ditadura, foi ampla em debates e produções científicas que, somadas às alterações legais como a Constituição Federal de 1988, trouxe novos ares e novas perspectivas para a educação nacional, impulsionando o movimento de reforma educativa nos estados.

No estado de São Paulo, as mudanças foram sentidas com a instituição da Jornada Única $^{37}$ (1988) e do Horário de Trabalho Pedagógico (HTP) que promoveram a ampliação do quadro da coordenação pedagógica e as discussões coletivas dentro da escola. Nesta época, cria-se a função do Professor Coordenador - PC. No entanto, a figura, ainda que embrionária, desse profissional na Rede Estadual Paulista de Ensino remonta ao final da década de 1960, associada à implantação do Grupo Escolar-Ginásio Experimental Dr. Edmundo de Carvalho (Experimental da Lapa) e dos Ginásios Vocacionais (FUSARI, 1997; GARCIA, 1995; SALVADOR, 2000).

$\mathrm{Na}$ Rede Municipal de Ensino de São Paulo, o horário coletivo de trabalho pedagógico foi instituido por ocasião da formulação do Estatuto dos Profissionais de Educação $^{38}$ em 1992, com a organização da Jornada de Tempo Integral ${ }^{39}$ (JTI). Todavia, a existência do cargo de coordenador pedagógico era anterior a esse momento, datava do ano de 1985.

Desde então, ampliaram-se as demandas de trabalho para o coordenador pedagógico, bem como as pesquisas sobre a atuação deste profissional, cada vez mais associada à formação do docente na escola, situação que vem se consolidando do ponto de vista institucional e administrativo, ressignificando o papel da formação de professores e os

37 A Jornada Única e o Horário de Trabalho Pedagógico foram instituídos pelo Decreto $\mathrm{n}^{\circ} 28.170$ de $21 / 10 / 1988$.

$38 \quad$ Lei no $11.229 / 1992$.

39 A sigla JTI referia-se ao nome da jornada que correspondia a quarenta horas-aula semanais de trabalho docente, modificada posteriormente para Jornada Especial Integral (JEI). 
conhecimentos para a formação em serviço, com destaque para a reflexão sobre a epistemologia da prática docente, que aproxima a produção teórica da didática da prática cotidiana das escolas.

\section{A coordenação pedagógica na Rede Municipal de Ensino de São Paulo}

Compreender o processo histórico ${ }^{40}$ da formação em serviço no município de São Paulo é imprescindível para uma acurada análise da atividade do coordenador pedagógico nessa rede, sendo essa reflexão indicativa de aspectos baseados em dados que apontam para sua regulamentação e uma regularidade de ação, o que inclui o contexto, a trajetória e o seu desenvolvimento na atualidade.

A análise que segue tem por base documentos do próprio município e produções de pesquisadores que remontaram à história da criação do cargo de coordenador pedagógico no município de São Paulo, principalmente a partir da legislação municipal. Mesmo esse processo representando apenas um lado da complexa teia de poderes que moveu a instituição desse cargo, ainda assim traz elementos que nos ajudam a compreender a trajetória desse profissional.

Embora esta investigação enfoque o coordenador pedagógico no município de São Paulo, é importante ressaltar que a figura desse profissional está disseminada pelo Brasil. Muitas vezes, em virtude das vicissitudes das condições de trabalho em cada estado e município, essa atividade fica ancorada em profissionais sem habilitação específica e sem recursos adequados. Essas condições criam uma diversidade de coordenação pedagógica e de critérios para o exercício da função. O estado de São Paulo é um exemplo desse fenômeno: a função de coordenador pedagógico apareceu de forma pouco organizada com a denominação de assistente pedagógico, em 1962. O cargo de 'coordenador pedagógico', como especialista

\footnotetext{
$40 \quad$ A esse respeito, Souza (2005) faz um interessante resgate, partindo da análise do início da organização da rede municipal de ensino de São Paulo, em 1956, em que identifica uma formação voltada ao treinamento, pautada no ensino de técnicas, métodos e procedimentos, e que passa por um período de mudança no conteúdo da formação. Tal mudança é impulsionada pelas teorias críticas que chegaram às escolas em função da redemocratização do país, até chegar em 2004, período abordado pela pesquisa, em que a formação sofre o desgaste das mudanças políticas internas, que interferem na concepção de formação adotada. A autora conclui o trabalho apontando a importância de alguns princípios como: considerar o professor, o diálogo - escutar professores e especialistas -, a participação, a autonomia, a coletividade, a relação teoria e prática, o respeito às necessidades formativas dos professores e a busca do desenvolvimento profissional, que, assumidos por qualquer gestão política, propiciam, segundo a autora, a formação em serviço desejável.
} 
envolvido com os processos educativos, toma forma por volta da década de 1970. Em 1971, as escolas estaduais já contavam com o assistente pedagógico, auxiliando o professor no desenvolvimento da ação pedagógica: planejamento, acompanhamento e avaliação.

No início, esse profissional era 'escolhido' dentre os professores licenciados em Pedagogia. Com a aprovação do Estatuto do Magistério Estadual, em 1974, criou-se a função de coordenador pedagógico em substituição à de assistente pedagógico. A Lei 201/78 de 09/11/78 (Estatuto do Magistério Público do Estado de São Paulo) definia o cargo de coordenador pedagógico dentro da classe de especialista, com provimento mediante concurso público, tendo como requisitos a licenciatura plena em Pedagogia, com especialização em supervisão escolar, e cinco anos, no mínimo, de experiência na docência. Contudo, o coordenador pedagógico como preconizado por lei, não se configurou de forma generalizada na rede de ensino do estado de São Paulo. Em seu lugar foi instituída em 1988, como já mencionado, a função de professor coordenador (PC) e em 1996, a função de professor coordenador pedagógico (PCP), exercida desde então sem habilitação específica, com a exigência de apenas três anos no exercício da docência.

A Rede Municipal de Ensino de São Paulo também tem uma história construída por descontinuidades políticas e, para conhecê-la, é necessário voltar um pouco mais no tempo, à gênese do ensino público municipal de São Paulo, que está ligada a um projeto de ação sistemática entre cultura e educação. Tal projeto fazia parte da política de reestruturação administrativa da prefeitura municipal de São Paulo, cuja origem ${ }^{41}$ data de 27/12/1945, com a implementação do Decreto-Lei que criou a Secretaria da Cultura e Higiene. Posteriormente, em 1947, desdobra-se em Secretaria de Higiene e Secretaria da Educação e Cultura, cabendo ao departamento de Cultura e Educação ${ }^{42}$ :

a) Promover a educação social da infância e dos adolescentes, aperfeiçoando-os física e intelectualmente; b) desenvolver nas crianças e adolescentes o espírito de cooperação e solidariedade humanas; c) assistir e recrear as crianças e d) difundir o ensino primário, vocacional e profissional. (Artigo 34, Decreto-Lei n ${ }^{\circ}$ 430/47)

O texto legal legitima as 'verdades' que nortearam a Educação durante algum tempo, apontando concepções que engendraram relações de poder, principalmente, pela forma homogênea como o conhecimento é tratado, pela sistemática das tarefas, pela própria organização do tempo e do espaço que agem sobre o corpo e a mente do professor, do aluno,

$41 \quad$ Revista Escola Municipal no 1, set de 1968 e no 10 , dez de 1981. 
do coordenador etc. Nesse contexto, acaba se naturalizando uma idéia de escola, de atuação docente e, posteriormente, de ação dos especialistas.

Com a expansão industrial brasileira, fruto da política federal de desenvolvimento, São Paulo, na década de 1950, transformava-se, para se tornar o maior centro industrial brasileiro. Nessa época, administrava o município o prefeito Juvenal Lino de Mattos, membro do Partido Social Progressista (PSP).

Foi neste contexto que, em 1956, organizou-se no município de São Paulo o primeiro Grupo Municipal de Ensino Primário Jaçanã, por meio do Decreto n ${ }^{\circ}$ 3.069/56 de 04/02/1956 e, logo depois, o Decreto no 3.070 de 07/02/56 que autorizava a então Secretaria de Educação e Cultura a construir prédios de propriedade da prefeitura para atender a demanda por alfabetização.

Souza (2005) afirma que a história do ensino paulista estava em consonância com a história nacional. Segundo a autora, “[...] o contexto municipal, atrelado ao que vivia o país, passou por transitoriedade e turbulência, repleta de ações políticas centradas no fisiologismo [...]” (2005, p.66), fato observável na política nacional e que repercutiu em nível estadual e municipal.

Assim, no início da Rede Municipal de Ensino de São Paulo, inserida no contexto nacional, a formação contínua era oferecida por meio de treinamento dos professores que se dava basicamente pela transferência de conhecimentos e métodos cuja aplicação produziria no aluno os objetivos esperados.

Essa concepção de formação permeou toda a década de 1960 e foi refinada na década de 1970 com a promulgação da Lei de Diretrizes e Bases da Educação Nacional (LDB) 5692/71, que institui os cargos técnicos em Educação.

A reforma universitária de 1968, que antecedeu a Lei de Diretrizes e Bases da Educação Nacional, em especial a reforma do curso de Pedagogia (1969), acabou por institucionalizar os especialistas de ensino mediante a especialização em administração escolar, orientação educacional e supervisão escolar, como determinava a lei.

A concepção de formação sistematizada no município de São Paulo produziu a criação de um órgão técnico, o Serviço de Orientação Pedagógica (SOP), que respondia pelas diretrizes pedagógicas das escolas da Rede Municipal de Ensino de São Paulo e caracterizavase por um atendimento técnico-pedagógico, visando à melhoria do ensino e do rendimento escolar. Era o início da supervisão escolar na Rede Municipal de São Paulo.

Com a organização do Departamento de Ensino Primário, em 1959, a Divisão Pedagógica (DP) assume as funções desenvolvidas pelo SOP que, em 1971, influenciado 
pelas mudanças da Lei 5692/71, recebe o nome de Divisão de Orientação Técnica (DOT), tornando-se responsável pelas diretrizes pedagógicas das escolas municipais e realizando, no sistema, a supervisão pedagógica do ensino municipal.

No processo de disciplinar e legitimar a escola pública municipal recém-concebida, criava-se no ano de 1969 a função de assistente pedagógico (AP) que correspondia à coordenação pedagógica na escola.

Todo o tempo, as ações institucionais carregaram a marca do controle político. Esse aspecto é facilmente identificado no processo de formação realizado. Em cada gestão, o professor era submetido a uma formação centralizadora que veiculava as diretrizes pedagógicas que comporiam as ações docentes. Dessa forma, o órgão de orientação técnica, responsável pela 'reciclagem do professor', nasce sob o desígnio de uma concepção homogeneizadora, todavia, sujeita às correlações de força próprias das relações de poder que, mesmo pouco desveladas, promoveram na história dessa rede de ensino e do coordenador pedagógico uma ressignificação de suas funções.

Segundo Perez (1992), desde seu início, a Rede Municipal de Ensino de São Paulo investiu na formação de seus profissionais. No entanto, sua atuação foi sempre de forma centralizadora, subordinando os ocupantes dos cargos por meio de treinamentos, relatos, avaliações e pacotes para serem aplicados em suas respectivas unidades:

[...] cabia aos assistentes pedagógicos e orientadores educacionais, a tarefa de viabilizar os planos realizados pelo órgão central. Para isso, eram treinados e controlados, não lhes restando outra opção se não tentar fazer o mesmo com os professores, pois a máquina técnico-burocrática estava sempre exigindo 'feedback' a fim de verificar se a execução correspondia ao que fora planejado. (PEREZ, 1992, p.16)

Conforme o relato anterior, a formação organizada pelos órgãos gestores do poder público, a ser desenvolvida com os especialistas (assistentes pedagógicos e orientadores educacionais), trabalhava para elaborar uma única e 'verdadeira' concepção de ensino, no entanto, tal processo desconsiderava, apesar de todo investimento na formação, o pouco controle que tinham sobre o resultado da ação formadora.

Souza (2005), refletindo sobre a trajetória da formação docente no município de São Paulo de 1956 a 1982, aponta esse período como pautado por treinamentos, privilegiando métodos, técnicas, procedimentos, recursos e planos baseados no princípio da neutralidade. Os especialistas, que surgiram nesse período como formadores, acabaram tornando-se executores das propostas da política pública vigente. Assim, a formação para os professores, por vezes, assumiu um caráter compensatório, considerando que, na década de 1980, o poder 
público atendia a grande massa carente da população sem acesso à escola. Fusari (1988, pp.78), analisando esse período, acrescenta:

[...] os treinamentos se propõem ingenuamente, como finalidade, mudar o comportamento do professor; o comportamento do professor é determinado fortemente por condicionantes sócio-econômicos que afetam e constroem o comportamento do cidadão que é educador. São esses aspectos: econômicos, políticos, culturais, pessoais, situação de classe social do sujeito - que determinam mais do que aquilo que um treinamento pode modificar. Alterar o comportamento do educador significa mudar o cidadão. Assim, essa finalidade denota uma certa ingenuidade dos profissionais responsáveis por treinamento, bem como um equívoco na política de treinamento.

De 1983 a 1992, impulsionados pela teoria crítica, outros elementos são introduzidos na formação proposta aos educadores da Rede Municipal de São Paulo. Mantiveram-se os treinamentos, mas a discussão pautava-se por debates sobre competência técnica e competência política, sobre a educação como prática dotada de intencionalidades. O final da década de 1980 e o começo da década de 1990 foram marcados pelos grupos de formação ${ }^{43}$ e por projetos, como o da interdisciplinaridade, que garantiram tempo na escola para pesquisa sobre a prática.

Essas considerações ilustram bem o caminho trilhado na formação dos primeiros especialistas, pelos órgãos do Estado responsáveis pelo controle do trabalho pedagógico e pela formação docente. Tal perspectiva também serviu de modelo para a formação dos profissionais do ensino. Preparar o professor era apenas uma variação da ligação entre ensino/aprendizagem desenvolvida com os alunos e do exercício dual do poder na relação professor/formador.

Em $1982^{44}$, houve a reestruturação da Rede Municipal de Ensino que promoveu modificações no Regimento Comum das Escolas Municipais ${ }^{45}$, apresentando de modo detalhado as funções do assistente pedagógico e do orientador educacional não mais vinculadas ao Secretário Municipal de Educação, mas ao diretor de escola. Esse regimento vigorou até 1985, quando, frente às novas discussões sobre a carreira do magistério, dá lugar a

\footnotetext{
43 O grupo de formação se constituiu em uma técnica de grupo de estudo que foi utilizada para a formação dos profissionais de educação (professores, coordenadores e diretores) durante a primeira gestão do Partido dos Trabalhadores (PT) no município de São Paulo, de 1989 a 1992.

$44 \quad$ A década de 1980 foi muito profícua em mudanças na sociedade e na educação, produto de transformações políticas que possibilitaram a anistia aos exilados, a votação direta em candidatos a cargos políticos e a introdução no país de novos autores sobre educação, lingüística etc, principalmente os de origem soviética como Vygotsky, L.S.; Leontiev, A. e outros.

$45 \quad$ O regimento das escolas municipais foi modificado algumas vezes, mas só no final da década de 1990 ele deixa de ser um regimento comum, para todas as escolas municipais, e passa a constituir-se como um regimento específico de cada escola, atendendo as deliberações da LDB, Lei no 9394/96, que preconiza a autonomia pedagógica, administrativa e de gestão financeira para as escolas públicas.
} 
um outro que estabelece o cargo de coordenador pedagógico, fundindo os cargos de orientador educacional (OE) e assistente pedagógico (AP), conforme nos relata Perez (1992). $\mathrm{Na}$ ocasião, havia poucos orientadores e assistentes efetivos, pois o último concurso havia sido realizado em 1976/1977 e os ocupantes da função eram designados, o que dificultava a oposição às diretrizes da administração.

Fusari (1997, p.31), mencionando o período que antecipou a criação do cargo de coordenador, faz a seguinte reflexão:

\begin{abstract}
Avaliações sucessivas e o próprio avanço das teorias de ensino foram mostrando o limite da divisão técnica do trabalho no interior das escolas, apontando para a direção de que, em vez da atuação especializada, a necessidade maior era o trabalho coletivo, conjunto, no qual os professores deveriam somar as competências e não ficar se debatendo na luta pela reserva de espaço de trabalho de cada um. Diretores, orientadores educacionais e assistentes pedagógicos deveriam trabalhar conjuntamente. Após 1985, as funções de AP e OE foram fundidas, não sem certa comoção, criando-se assim o cargo de coordenador pedagógico (CP), como é hoje conhecido.
\end{abstract}

Perez (1992, p.32), ao analisar o surgimento do cargo de coordenador pedagógico na Secretaria Municipal de Educação de São Paulo, diz que:

Pode-se afirmar que no início do exercício, a maioria dos coordenadores pedagógicos podia ser considerada como personagens em busca de seu papel para, progressivamente, transformarem-se em profissionais perseguindo alguns juntamente com os professores - a construção do seu fazer nas escolas.

A reflexão da autora revela um pouco da tensão que constituiu, nesse primeiro momento, o movimento de resistência dos profissionais que fugiam do pejo de uma identidade preconcebida pela associação com o cargo de orientador educacional, o que revela os enfrentamentos que precederam aos arranjos e às convergências que formularam saberes sobre a ação docente e sobre o papel do coordenador pedagógico. No entanto, o que ficou consolidado na época foi uma coordenação com uma função fiscalizadora e burocrática, não havia preocupação com a formação docente, porque, como Cunha $(1999$, pp.144, 145) afirma:

Não há lugar na escola tradicional para a preocupação com a educação dos professores. Eles são considerados já educados, prontos, produto de uma sociedade que deve repetir-se, perpetuar os interesses da classe dominante, da burguesia liberal. A escola está aberta para todos e os professores ensinando a todos da mesma forma. 
O cargo de coordenador pedagógico vem desde então sendo re-escrito e reconfigurado pelas mudanças na legislação da educação municipal, pelo avanço nas investigações sobre o trabalho dos especialistas na escola, pelas mudanças sócioeconômicas que têm interferido na organização das escolas públicas, pelas diversas compreensões dos profissionais que assumem a função e pelas condições materiais objetivas oferecidas à escola.

Assim, o coordenador, logo no início, agrega em sua ação, competências que eram desenvolvidas pelos OEs, que atuavam na articulação professor/aluno e individualmente com o aluno, e pelos APs, que, segundo o Regimento Interno das Escolas de Primeiro Grau de 1973, detinham as funções de:

- Coordenar a elaboração do planejamento didático-pedagógico anual da escola de modo a garantir sua unidade e a efetiva participação de todo o corpo docente e do orientador educacional;

- Acompanhar a execução do planejamento em cada período letivo, avaliando seu rendimento, detectando seus defeitos e promovendo meios para a correção dos mesmos;

- Assistir todas as atividades ligadas à execução do plano didático e assessorar o corpo docente e a direção da escola no tocante ao atingimento das metas fixadas;

- Promover reuniões periódicas com os professores para a crítica do trabalho docente e o estudo dos casos que exijam mudanças de métodos e processos. (GATTI, et al,1974, p. 9).

Paulatinamente o trabalho do coordenador vai ganhando uma 'fisionomia', voltada para o acompanhamento e desenvolvimento pedagógico e para a organização das atividades docentes não como inspetor, mas como integrador e articulador das ações pedagógicas e didáticas na escola, até assumir como prioridade, principalmente a partir da década de 1990, dentre as suas funções, a organização coletiva da formação do professor na escola, bem como o acompanhamento e a avaliação desse processo.

Parte da demanda da formação do docente na escola esteve associada à criação do Estatuto do Magistério Público Municipal de São Paulo, Lei $\mathrm{n}^{\circ}$ 11.229/1992, que oportunizava aos professores a opção por uma Jornada de Tempo Integral (JTI), atualmente Jornada Especial Integral de Formação (JEIF), que garantia tempo remunerado para o desenvolvimento do processo formativo na escola.

Sendo assim, é possível afirmar que essas transformações históricas teceram uma rede institucional que foi caracterizando o modo de ser coordenador pedagógico, mediado por concepções e 'leis' que, embora restritas ao tempo, foram sendo buriladas pelos movimentos de resistência, produtos de compreensões diversas sobre essa atividade profissional. Segundo Souza (2005, p.121):

O coordenador que foi tido como 'vigia', 'controlador' das práticas dos professores, inocente e ao mesmo tempo impositivo ao trabalhar para 
viabilizar as propostas do governo, também já foi vítima e ousado. Em algumas escolas, temos vivências relevantes em relação à prática dos coordenadores pedagógicos, que desafiam e constroem junto com o grupo de professores inúmeros saberes. (destaque do autor)

Nesta perspectiva, um coordenador pedagógico pode trabalhar moldado por concepções que o aproximam ou o afastam de uma prática em prol da autonomia intelectual dos professores.

O discurso da escola como locus de formação do professor reflexivo tem ratificado a idéia do professor como sujeito do seu fazer, pesquisador da sua prática, não mero executor de políticas públicas, mas como profissional capaz de elaborar, definir e reinterpretar o seu fazer, relacionando-o com os contextos sociais e econômicos e com os conhecimentos produzidos, portanto, capaz de pensar sua própria formação. Porém, esse mesmo discurso, quando incorporado pelos órgãos públicos, pode isentá-los de qualquer investimento na formação contínua de seus professores, especialmente quando a formação contínua, proposta pelas equipes das Secretarias de Educação, não resolve os problemas do cotidiano, o que acaba por gerar conflitos e resistências de ambos os lados.

No ensino municipal, as propostas de reformas são instituídas por meio da legislação que vão legitimando 'verdades' que devem guiar o sistema. Esse fenômeno é observado na progressiva mudança do Regimento Comum das Escolas Municipais. O regimento de 1985 foi revogado pelo Decreto ${ }^{\circ} 32.892$ de dezembro de 1992, que propõe mudanças na forma de organização da escola pública, especialmente em relação às funções do coordenador pedagógico, e também reforça a participação desse profissional na elaboração do plano escolar, no acompanhamento pedagógico e na elaboração coletiva de projetos de formação para serem desenvolvidos no horário coletivo de trabalho proporcionado pelo Estatuto do Magistério Municipal.

Posteriormente, o Decreto no 33.991 de 24/02/1994 alterou o regimento anterior, mas não trouxe grandes mudanças em relação à função do coordenador pedagógico. Em 27/11/1997, a Deliberação CME no 3 e a Indicação CME nº 4, da mesma data, estabelecem diretrizes para a elaboração do regimento escolar dos estabelecimentos de Educação Infantil e de Ensino Fundamental e Médio vinculados ao sistema de ensino do município de São Paulo. Embora este tenha sido um processo acompanhado e assessorado pela supervisão pedagógica e a orientação fosse a observância da autonomia das escolas e de suas peculiaridades, os regimentos ainda assim acabaram por se tornar muito parecidos e trazerem a marca dos documentos que os orientavam. Quanto à atuação da coordenação pedagógica, houve poucas alterações, mesmo de escola para escola. 
Atualmente, o regimento da escola, por seu caráter particular, caracteriza cada estabelecimento e tem como princípio o respeito às necessidades e peculiaridades de cada escola.

Os documentos que contam a história do município e suas leis, nessa perspectiva, constituem-se em fontes de informação que, sistematizadas, podem apontar elementos que auxiliem na compreensão de como se procede a elaboração da ação do coordenador pedagógico, bem como as influências recebidas nesse processo.

Num espaço tão plural quanto a instituição escolar, a cultura compõe-se de forma multifacetada, fruto das inter-relações e correlações de poder que o espaço possibilita e que compõem a rede de significados compartilhados. Segundo Pérez Gomes (2001), o campo da cultura é, também, o de produção de sentidos e, por isso, na escola, é importante considerar não uma cultura, mas um entrecruzamento de culturas que, no decorrer do tempo, re-elaboram a identidade de seus sujeitos.

Desta forma, compõem essa análise as incertezas e a descontinuidade, frutos da racionalidade opaca e contraditória dos processos, que impõem à escola demandas atreladas a essas novas condições. Associados a essas mudanças, estão aspectos relacionados às políticas públicas para a Educação, que regem o funcionamento das escolas desde a sua criação, ou seja, a construção do prédio, a seleção de professores, a aquisição do mobiliário, a mobilidade de alunos e professores, a implantação de um currículo generalista (Parâmetros Curriculares Nacionais, Referencial Curricular Nacional para a Educação Infantil, dentre outros) que vão conjuntamente elaborando uma identidade cultural das escolas.

O trabalho do coordenador pedagógico, no século XXI, como gestor dos processos de formação, tem especial importância, pela possibilidade de condução de uma reflexão que produza a consciência das identidades possíveis frente às descontinuidades da contemporaneidade, das determinações das políticas públicas e das necessidades educativas da comunidade.

Conforme já mencionado neste capítulo, desde a criação do cargo de coordenador pedagógico em 1985 na Rede Municipal de Ensino de São Paulo, os governos vêm investindo numa formação contínua desse profissional, muitas vezes de forma desarticulada, entendendoo apenas como mediador das políticas públicas na escola.

Um exemplo disso foi o curso, na modalidade de formação contínua oferecido em 1996 aos coordenadores pedagógicos, recém-ingressantes, pela SMESP em parceria com a Fundação de Apoio à Faculdade de Educação (FAFE), da Universidade de São Paulo, denominado $O$ coordenador pedagógico: identidade em construção. $\mathrm{O}$ curso proposto inovou pela oportunidade de organização de projetos de atuação pelos participantes e por atender a 
uma demanda por formação, em virtude do grande número de profissionais que ingressaram no cargo. $\mathrm{Na}$ época, todos os coordenadores efetivos foram convocados a participar desse processo de formação. No entanto, essa proposta formativa organizada pela SME separou os coordenadores, que fizeram o curso na FEUSP, dos diretores, que fizeram o curso na Faculdade de Administração e Economia (FAE) da USP. A opção pela separação desses profissionais no processo formativo acabou por reforçar a idéia de distanciamento entre o administrativo e o pedagógico nas escolas.

Em 2001, o segundo mandato do PT trouxe uma nova idéia de supervisão, o Grupo de Acompanhamento da Ação Educativa (GAAE). Cada GAAE atendia a um pólo, composto por aproximadamente de cinco a seis escolas, próximas geograficamente, articulando junto aos coordenadores pedagógicos projetos de formação em rede ${ }^{46}$ no horário coletivo. Tal ideia não resistiu à mudança no governo municipal, mas trouxe para a reflexão um conceito alargado de formação na escola, não como um processo isolado de cada estabelecimento de ensino, mas como redes de formação que incluíam o supervisor, o assistente técnico educacional e um elemento da universidade ${ }^{47}$.

Nos últimos anos, pouco se tem feito no sentido de promover a formação reflexiva do coordenador pedagógico. Os cursos oferecidos aos coordenadores pedagógicos na rede municipal de ensino de São Paulo caracterizam-se por estar altamente atrelados à implementação dos projetos de governo ${ }^{48}$, configurando-se como instrucionais. Eles foram organizados a fim de favorecer sua reprodução na escola, para isso fica comprometido o horário coletivo de trabalho pedagógico, cujos projetos, por força de portaria, devem privilegiar os programas oficiais, muitas vezes, independente do percurso de cada unidade. Não se trata aqui de julgá-los como bons ou maus, mas de considerar que organizados desta forma desconsideram os saberes dos coordenadores e de professores e a possibilidade de autonomamente cada escola optar por seus projetos formativos.

\section{A pedagogia e a formação inicial do coordenador pedagógico}

\footnotetext{
46 A expressão projetos de formação em rede refere-se àqueles elaborados por um conjunto de escolas com dificuldades ou interesses formativos comuns.

$47 \quad$ Inicialmente a Secretaria Municipal de Educação estabeleceu contratos com a Pontifícia Universidade Católica de São Paulo e a Faculdade de Educação da Universidade de São Paulo que fizeram o diagnóstico das necessidades formativas da rede. Posteriormente, os membros da universidade foram sendo contratados, não como uma assessoria diretamente compondo o GAAE, mas para atender projetos específicos das unidades.

48 Os coordenadores de EMEFs, ciclo I e II, tiveram formação para desenvolver o "Programa Ler e escrever - Prioridade na Escola Municipal” que contempla três projetos: "Toda Força ao Primeiro Ano" (TOF), "Projeto Intensivo do Ciclo I" (PIC), "Ler e Escrever em todas as áreas do ciclo II". Também receberam os guias de orientações formulados para os coordenadores e para os professores.
} 
O primeiro conjunto de proposições no relato das coordenadoras revela, na perspectiva dessas profissionais, uma inadequação da formação inicial, que não as preparou para as tarefas específicas da coordenação pedagógica. Enquanto parece claro o que se espera do diretor e do supervisor escolar, o coordenador está sempre à deriva das demandas da multiplicidade do trabalho pedagógico na escola e das determinações das políticas públicas.

As coordenadoras entrevistadas têm formação em Pedagogia, habilitação necessária para o ingresso no cargo na rede municipal de ensino de São Paulo. No entanto, apontam uma ineficácia dessa formação. Segundo elas:

Fui fazer pedagogia, minha intenção era trabalhar na direção de escola, [...] fiz o concurso para coordenador e assumi o cargo com a visão de professor mesmo, e até hoje eu sou uma defensora do professor porque eu sempre me senti como professora. [...]. Porque eu penso que tudo o que aprendi na minha função foi na prática, posso até não ter feito nenhuma reflexão mais profunda, mas não consigo me lembrar de alguma coisa que eu tenha aprendido na pedagogia que esteja usando, não consigo, sinceramente. (COORD. MARIA VITÓRIA)

Minha formação em pedagogia não me deu base para o trabalho na coordenação pedagógica, de jeito nenhum. Eu acho que a formação que eu tive, até por ter escolhido administração escolar, me deu muito mais embasamento legislativo, de administrador de escola, do que exatamente de coordenador pedagógico. [...] depois eu fiz supervisão e o curso não deu base nem para ser supervisor. [...] talvez a própria faculdade não oferecesse um curso de qualidade, pois o conhecimento se restringia à legislação e ao estágio [...], embasamento pedagógico para o exercício da função de coordenador, especificamente, não tive nenhum. (COORD. MARIA LEDA)

No curso de complementação, eu estudei um ou outro autor, mas muito superficial, de prática mesmo não tivemos nada. Então acaba sendo algo de construção empírica, no dia-a-dia. (COORD. MARIA STELLA)

A pedagogia na PUC me preparou mais para ser professora do que para ser coordenadora. Como eu dava aula de didática e de prática de ensino no magistério, eu acompanhava muito as alunas no estágio. A gente realizava um estágio muito legal e eu aprendi muito com ele. As crianças adoravam e os alunos do magistério também, porque tinham a oportunidade de vivenciar a docência. E eu, naquela época, estava aprendendo a ser coordenadora pedagógica porque estava orientando o trabalho deles. Quando os professores da escola privada me indicaram para ser coordenadora pedagógica, logo percebi que de um lado eu tinha um diretor que queria que eu fosse menina de recado e do outro os professores que queriam uma aliada. $\mathrm{E}$, então, eu fui percebendo que tinha que construir um papel de coordenadora que as pessoas respeitassem. (COORD. MARIA AUGUSTA) 
As coordenadoras foram unânimes ao afirmar a pouca contribuição da formação inicial para o desenvolvimento do trabalho da coordenação pedagógica na escola, o que se contitui num dos fatores para que o profissional, no começo da carreira, tenha mais dificuldades.

Os cursos de Pedagogia caracterizavam-se, segundo os relatos, por uma formação generalista visando a atender a multiplicidade das funções dos profissionais que recebem o título de pedagogo, que passam a atuar no sistema de ensino, nas salas de aula como professores ou como especialistas; na pesquisa educacional; nos movimentos sociais; nas diversas mídias; nas áreas de saúde e assistência social; nas empresas; nos sindicatos etc.

Libâneo (2002) faz uma reflexão sobre o que deveria caracterizar o curso de pedagogia. Para o autor, existem especificidades nos diversos campos da atividade pedagógica do pedagogo não docente que precisam ser, impreterivelmente, consideradas na formação desse profissional. Ele entende que o curso de pedagogia deveria ser destinado exclusivamente a formação do pedagogo:

A retomada da formação específica para atividades de organização/gestão e coordenação pedagógica das escolas é uma necessidade improrrogável dos sistemas de ensino. Cada vez mais se requer a presença de um diretor de escola atuante e preparado, inclusive para novas situações que vão surgindo frente a novas realidades sociais, econômicas, culturais. O coordenador pedagógico é um profissional imprescindível para assegurar nas escolas a integração e articulação do trabalho pedagógico-didático: a formulação e acompanhamento da execução do projeto pedagógico-curricular, a organização curricular, a orientação metodológica, a assistência pedagógicodidática aos professores na sala de aula numa relação interativa e compartilhada com os professores e alunos, colaboração nas práticas de reflexão e investigação, diagnóstico e atendimento das necessidades ligadas ao ensino e a aprendizagem dos alunos em conjunto com o professor, atividades de formação continuada, práticas de avaliação da aprendizagem. Para tantas, e imprescindíveis tarefas, faz-se necessária uma formação específica, é para isso que se propõe um curso de pedagogia ou estudos pedagógicos. (LIBÂNEO, 2002, p. 74, grifo nosso):

O coordenador pedagógico é um dos atores na trama educacional cuja especificidade da atuação profissional requer uma formação inicial inerente à função, que o impulsione ao desenvolvimento de sua profissionalidade para atender a amplitude dessa ação profissional, conforme ilustrada por Libâneo (2002). A proposta não advoga a separação entre o pedagógico e o administrativo, pois a gestão escolar deve estar alicerçada numa concepção de 
trabalho educativo partilhada entre seus profissionais. Porém, tal perspectiva pode contribuir para a melhoria da formação inicial do coordenador pedagógico.

Christov (2001) acrescenta a essa análise outra ideia que ajuda a pensar sobre a negação explícita, das coordenadoras pedagógicas ouvidas, sobre o papel da formação inicial para o exercício da função. No dizer da autora:

Permito-me registrar a hipótese de que os coordenadores pedagógicos ouvidos nesta pesquisa - e tantos outros educadores com os quais tenho atuado em diferentes projetos de educação continuada - não reconhecem a formação inicial como locus de preparo para o exercício da profissão porque, na maioria das vezes, foram espectadores da verdade científica apresentada por seus professores, sem serem provocados a questionar e a criar suas hipóteses para compreender as teorias e as realidades às quais se referiam. Viveram uma relação distanciada com o conhecimento, quando não negadora deste, afastando-se da possibilidade de se perceberem produtores de conhecimento. (CHRISTOV, 2001, p. 138)

Considerando tal afirmação, frente ao discurso das coordenadoras, infere-se que uma formação inicial que não considera os saberes prévios dos formandos, ou lhes nega a condição de produtores de conhecimento, tende a produzir um afastamento das idéias trabalhadas nessa formação, cujo sentido prático escapa aos futuros profissionais, o que lhes dificulta encontrar o sentido entre essa primeira formação e a prática cotidiana, mesmo quando a atuação profissional re-edita as ações autoritárias vividas naquele momento.

Assim tanto uma formação aligeirada como uma formação que não considera os sujeitos envolvidos podem produzir um 'especialista' despreparado para o enfrentamento das exigências postas pelo mundo contemporâneo. Desta forma, especialmente, o coordenador pedagógico, cuja função tem sua identidade ainda em transformação, sofre pelo impacto do ingresso numa nova profissão e das transformações nas demandas de trabalho. As coordenadoras pedagógicas revelaram uma ineficácia da formação inicial que não lhes garantiu os conhecimentos essenciais para que, no exercício da profissão, fossem estabelecidas as bases para as re-elaborações que se seguiriam ao ingresso no cargo.

A partir dos depoimentos das coordenadoras sobre a formação inicial em Pedagogia, é possível compreender que os cursos apresentavam um currículo generalista para a formação do especialista, comprimido pelo tempo entre várias áreas de atuação possível para os provenientes desse curso. Essa situação não difere muito do que acontece na atualidade, em que os cursos de Pedagogia, ao término, habilitam para o exercício do magistério em nível de $1^{\mathrm{o}}$ ao $4^{\circ}$ ano do ensino fundamental e, também, o faz para as funções de supervisor, diretor e 
coordenador pedagógico, congregando mais de uma habilitação em um único currículo. Libâneo (2002, p. 84) tece a seguinte consideração sobre essa prática:

\begin{abstract}
Ao meu ver, para se atingir níveis mínimos desejáveis de qualidade da formação, ou se forma um bom professor ou um bom "gestor" ou coordenador pedagógico [...]. Não é possível formar todos esses profissionais num só curso, nem essa solução é aceitável "epistemologicamente" falando. A se manter um só currículo, com o mesmo número de horas, teremos um arremedo de formação profissional, uma formação aligeirada, dentro de um curso inchado.
\end{abstract}

Assim, o currículo generalista desses cursos que abarca a formação para o desenvolvimento de atividades diversas, de professor ao pedagogo, nas suas muitas atuações, não desenvolve aspectos específicos do trabalho na coordenação pedagógica que estão ligados, inclusive, às etapas de desenvolvimento dos alunos. Na Secretaria Municipal de Educação de São Paulo (SMESP) existem: os Centros de Educação Infantil (CEIs), as Escolas de Educação Infantil (EMEIs), as Escolas de Ensino Fundamental (EMEFs), as Escolas Municipais de Educação Especial (EMEEs), as Escolas Municipais de Ensino Fundamental e Médio (EMEFMs) que trabalham com públicos distintos, todos com particularidades que exigem da coordenação pedagógica conhecimentos e habilidades mais específicas.

Há que se considerar, em cada escola, a formação diversa dos professores, alguns com formação no magistério, outros em Pedagogia ou disciplinas específicas (português, matemática, história, geografia, ciências, educação física, inglês, artes e outras). Condicionantes esses que revelam a singularidade e as especificidades em que a formação inicial do coordenador pedagógico não toca. É inegável que uma atuação profissional bem alicerçada traz sempre contribuições que auxiliam em sua prática que, no caso do coordenador, está relacionada a conhecimentos sobre o professor, seus saberes, sua metodologia, seu processo reflexivo; sobre os alunos, sua maneira de aprender, sua interação com os colegas e com os professores; sobre a comunidade e suas expectativas em relação à escola e seu atendimento; e sobre o diretor e as demandas do trabalho na perspectiva da cooperação.

Como se vê, o pedagógico na escola tem muitas frentes, talvez a principal delas seja o trabalho com os professores, com interface no desenvolvimento educativo dos alunos, mas mesmo essa intervenção precisa ser cuidadosa, pois existe uma tensão que é muito bem apontada pela coordenadora Maria Stella: 
O coordenador tem de se concentrar nas questões pedagógicas, tem que ter predisposição grande para estudar, tem que exercer a liderança sobre o grupo de professores, não de uma forma impositiva, mas como mediação. Quando você fala do trabalho do professor, não dá para falar: você vai trabalhar assim! Tem que ter todo um processo de convencimento, de estudo, de levar à reflexão, de promover o conflito em relação às suas crenças pedagógicas: Como vocês estão fazendo isto? Mas por que estão fazendo assim? O que nós podemos modificar para melhorar ainda mais? Então, é um processo de convencimento mesmo. Mostrando, estudando e conversando.

Mesmo ponderando-se que o curso de Pedagogia ${ }^{49}$ poderia proporcionar a base para o exercício da função de coordenador pedagógico, é preciso considerar que a função, ainda, transita entre a supervisão escolar e a orientação educacional, embora sua ação não se constitua numa coisa nem noutra; por vezes, irrefletidamente, manifesta aspectos peculiares às duas funções. O depoimento da coordenadora Maria Stella aponta para um currículo de formação que considere as diferentes relações estabelecidas nessa atividade, bem como a pesquisa como instrumento de construção do conhecimento, uma vez que tal prática profissional exige 'predisposição para estudar' e reflexão sobre a própria atuação formativa. Clementi (2005) entende que a qualidade da formação dos profissionais que atuam na escola não tem melhorado porque os formadores, tanto na universidade como os próprios coordenadores nas escolas, têm uma falta de preparo formal. Segundo a autora:

Certamente, o coordenador tem muito a dizer sobre suas necessidades, desde que lhe seja dado espaço para isso. A questão da legitimação de seu papel passa também por um processo de profissionalização, entendido como a ruptura de uma postura formal e formalizada, para uma postura de investigação e descoberta (CLEMENTI, 2005, p. 63)

Não existe aqui uma defesa superlativa da especialização dos educadores que trabalham ligados à equipe diretiva da escola (diretores, coordenadores e supervisores). Não se pretende, também, particularizar e fragmentar ainda mais o trabalho das equipes escolares. Contudo, é necessário pensar de forma sistemática quais saberes ajudam no exercício da função do coordenador, não só em relação à prática localizada, mas no processo reflexivo

\footnotetext{
49 A LDB, Lei ${ }^{\circ}$ 9394/96, trouxe novas demandas para a formação dos professores que atuariam na educação básica, portanto, sobre as diretrizes do curso de Pedagogia, considerando a complexidade da formação docente. A lei passou a ser regulamentada no início de 2001 com o parecer CNE/CP 09/2001 e pela Resolução 01/2002, culminando com o Parecer 05/ 2005 reafirmado pela Resolução CNE/CP 01/2006. Essas diretrizes tendem a influir no currículo dos cursos de pedagogia em todo território nacional, porém não será tema de discussão neste trabalho. Ghedin, E., Leite, Y.U.F. e Almeida, M. I. (2008) analisam a influência da legislação na configuração dos cursos de Pedagogia.
} 
desse profissional. Clementi (2005, p.65) compreende esta necessidade e faz a seguinte ponderação:

\begin{abstract}
A responsabilidade da pedagogia que está sendo desenvolvida na escola é também do coordenador que, objetivamente, junto com os professores, a transforma em prática. A falta de formação adequada desse profissional, a falta de respaldo das instituições particulares e públicas e a desmotivação fazem com que não se realizem momentos de reflexão fundamentais aos educadores para a vivência desta escola que a sociedade exige. (grifo nosso)
\end{abstract}

Segundo a autora, uma formação adequada para o coordenador pedagógico é fundamental para que haja um trabalho eficaz em prol do desenvolvimento docente no horário coletivo, de tal modo que promova uma reflexão capaz de gerar a transformação da profissionalidade dos educadores participantes.

Libâneo (1996) entende que níveis diferentes de práticas pedagógicas exigem requisitos específicos para o exercício profissional. Segundo o autor:

A atuação do pedagogo escolar é imprescindível na ajuda aos professores no
aprimoramento do seu desempenho na sala de aula ( conteúdos, métodos,
técnicas, formas de organização da classe), na análise e compreensão das
situações de ensino com base nos conhecimentos teóricos, ou seja, na
vinculação entre as áreas de conhecimento pedagógico e o trabalho de sala
de aula. [...] Há uma tendência de construção de escolas cada vez maior, com
consequiências na organização do espaço físico e dos recursos materiais, na
gestão do processo organizativo, na organização administrativa e curricular,
na coordenação das atividades pedagógico-didáticas dos professores.
São tarefas complexas que requerem habilidades e conhecimentos
especializados, tanto quanto se requer por parte do professor conhecimentos
especializados da matéria que leciona. (LIBÂNEO, 1996, p. 127, grifo
nosso)

Com a promulgação da Lei de Diretrizes e Bases da Educação Nacional, nº 9394/96, acirrou-se um debate nacional sobre a formação a ser oferecida nos cursos de Pedagogia, principalmente pela separação explícita, em seus artigos, entre formar o docente e o especialista em Educação.

A formação de profissionais da educação para administração, planejamento, inspeção, supervisão e orientação educacional para a educação básica será feita em cursos de graduação em pedagogia ou em pós-graduação, a critério da instituição de ensino, garantida, nesta formação, a base comum nacional". (Artigo 64, Lei 9394/96) 
Desde a década de 1970 - quando esses profissionais aparecem no cenário nacional -, parece haver um investimento cada vez maior na especificidade dos profissionais de ensino. Porém, a formação inicial do coordenador pedagógico ainda não se estabelece de modo peculiar e transita entre outras habilitações, o que dá margem a inúmeras leituras e definições sobre suas atribuições, normalmente vinculadas às determinações do poder público.

Algumas instituições mantêm as tradicionais habilitações/especializações em supervisão escolar, administração escolar e orientação escolar. Mesmo que elas estejam, do ponto de vista curricular, altamente imbricadas, ainda assim existem peculiaridades que a formação inicial deve procurar contemplar.

Quando as universidades não habilitam de forma específica para a coordenação pedagógica, podem apresentar agregadas ao currículo de formação de outros especialistas conteúdos relativos à atuação do coordenador. Por vezes, esses conteúdos estão implícitos na formação do supervisor escolar, que, conforme já explicitado, tem certa proximidade histórica com a coordenação pedagógica. Naturalmente, essa análise não está descolada de uma série de fatores, entre eles a existência, nos estados e municípios, do cargo ou da função de coordenador pedagógico. Em alguns estados, o profissional com formação em supervisão escolar está habilitado para concorrer ao cargo de coordenador pedagógico, embora exista uma diferença na atuação desses dois profissionais; em outros, a supervisão pedagógica corresponde à coordenação pedagógica.

Uma educação preocupada com a constituição de um coordenador crítico-reflexivo estará atenta aos aspectos referentes a um currículo de formação menos técnico e mais reflexivo, pois tal perspectiva pode influir nas configurações dessa profissão nos estados e municípios brasileiros onde ela é desenvolvida. Todavia, sua caracterização pode, ainda, ser fruto de políticas públicas diversas, algumas pouco comprometidas com o pedagógico e fortemente alicerçadas nas idéias impostas pelo mercado, num processo aligeirado de educação (formação inicial e contínua) e outras empenhadas numa educação democrática, de qualidade para todos. As concepções que norteiam a educação permitem, por serem muitas, produzir sentidos diversos para a função de coordenador pedagógico, criando, muitas vezes, uma identidade instável.

Se a concepção de coordenador pedagógico presente nas universidades pode ser dispersa, o que se dirá das compreensões pessoais de quem exerce a função, produto de uma formação deficiente, de experiências educativas negativas, da falta de autonomia ou de apoio do sistema, de crença numa educação focada na transmissão de conhecimento e pautada pelas idéias de uma racionalidade técnica. 
Pinto (2006), referindo-se à coordenação pedagógica, menciona uma variação de nomenclatura, existente nos vários municípios e estados brasileiros, para designar a função: supervisão pedagógica, supervisão escolar, supervisão educacional, assistência pedagógica, orientação pedagógica. Embora, a terminologia seja diferente, segundo o autor, todas designam o trabalho de acompanhamento da ação pedagógica do corpo docente.

É importante observar que a formação inicial exigida daqueles que exercem a 'função' de coordenador pedagógico parece carecer, também, de certa coerência. Existe, por parte do empregador, formulador de política pública, uma compreensão diversa sobre a formação necessária ao profissional responsável pela coordenação pedagógica nas escolas públicas. Exemplo clássico é o caso do estado de São Paulo em que o Professor Coordenador Pedagógico (PCP), que assume as atribuições do coordenador pedagógico em caráter temporário, o que pressupõe certa descontinuidade dos projetos pedagógicos, não precisa ter necessariamente licenciatura em Pedagogia. Christov (2001) evidencia no discurso dos coordenadores da Rede Estadual de São Paulo a necessidade de um preparo em relação aos conhecimentos pedagógicos, o que, também, aparece na fala de outros educadores da mesma rede: "[...] quanto os ouvimos criticando o fato deste sistema não exigir formação em pedagogia para o exercício da coordenação" (p. 83). Segundo a autora, a dificuldade existe porque grande parte dos coordenadores, formados em diversas áreas do conhecimento, não vivenciaram em seus cursos de formação inicial a discussão de questões pedagógicas, essenciais ao exercício da coordenação.

Na Rede Municipal de Ensino de São Paulo esta situação é inversa. Um dos requisitos para o exercício da coordenação é exatamente a formação em Pedagogia com habilitação em supervisão escolar, além de três anos de experiência na docência. Esse profissional, ao ingressar na escola por meio de concurso público, passa a ocupar o cargo de coordenador pedagógico, o que lhe atribui certa estabilidade profissional.

Assim, a exigência por uma formação em Pedagogia, condição que poderia garantir certa unidade nacional à função de coordenador pedagógico, não se constitui, necessariamente, em requisito inicial para o exercício do cargo. Como foi apontado, essa é a realidade paulista, em que qualquer professor com experiência na docência e um projeto de trabalho pode, após uma seleção prévia, exercer a coordenação pedagógica. Situação como essa fatalmente se repete em outras partes do país, o que acentua o problema de identidade profissional do coordenador pedagógico. 
Pinto (2006, p. 4) ao refletir sobre o papel do pedagogo escolar não docente, também corrobora com a idéia de uma formação pedagógica consistente para esse profissional:

\footnotetext{
Essa contribuição do pedagogo consubstancia-se, fundamentalmente, em torno do trabalho docente-discente - ao oferecer suporte pedagógico para que os professores garantam a aprendizagem dos alunos - numa atuação que é de mediar os processos de ensino aprendizagem que ocorrem nas escolas. Para tanto, esse profissional deve ter uma formação qualificada no campo do conhecimento pedagógico. (grifo nosso)
}

$\mathrm{Na}$ declaração acima, cuja referência é o coordenador pedagógico, o autor salienta a importância desse profissional ter uma formação qualificada no campo do conhecimento pedagógico. Nesse sentido, a formação do especialista 'pedagogo' precisa ser alvo de reflexão dos gestores de políticas públicas para o Ensino Superior e dos profissionais que trabalham com a formação em Pedagogia, pois a atuação dos especialistas pedagogos exige conhecimentos e ações especializadas frente às demandas escolares desse início do século XXI, principalmente com o deslocamento da formação contínua do docente para a escola como atribuição específica do coordenador pedagógico.

\section{A formação contínua do coordenador: um emaranhado de experiências}

As participantes desta pesquisa apresentaram em suas memórias as experiências que as ajudaram a torná-las coordenadoras, compondo dessa forma a função. A coordenadora Maria Vitória afirmou que 'o que aprendeu sobre a coordenação pedagógica foi na prática', já a coordenadora Maria Stella apontou 'a importância da troca de experiência, do contato com outros profissionais da área'. A coordenadora Maria Leda enfatizou 'que no início, como o sistema não oferecia cursos específicos para coordenadores pedagógicos, ela e outras coordenadoras pagaram uma assessoria para ajudá-las'. A coordenadora Maria Augusta relatou 'sua experiência de formadora de professores no curso de magistério como a base de suas referências para o exercício da coordenação pedagógica'.

Estes jeitos pessoais de formarem-se no exercício da própria coordenação seguem a mesma lógica já explorada pelas pesquisas disponíveis sobre o desenvolvimento profissional docente. Os coordenadores utilizam-se, inicialmente, das suas experiências como professores, da experiência de outros coordenadores pedagógicos e de cursos de formação contínua, alguns 
oferecidos pelo sistema e outros produto da busca pessoal de cada profissional como referências para sua atuação profissional inicial.

No âmbito da própria coordenação pedagógica, desenvolve-se, no espaço educacional, os saberes técnicos, as relações interpessoais, o trabalho em grupo, a liderança, a organização da escola, a compreensão da legislação pertinente que desemboca na particularidade de cada sala de aula e em cada escola ou sistema de ensino.

Clementi (2005), ao analisar a complexidade da escola e as exigências da sociedade atual em relação a ela, traz a seguinte reflexão sobre os saberes necessários ao trabalho do coordenador pedagógico na formação contínua dos docentes "A falta de clareza do que significa ser um formador de professores, a falta de conhecimento do que seja a construção e a vivência do projeto pedagógico são fatores que intervêm em sua atuação" (p.56). E, ainda, ratificando a fala das coordenadoras entrevistadas, acrescenta, referindo-se especificamente à formação dos coordenadores:

A falta que um trabalho de formação faz para o coordenador também é fator
que interfere em sua prática. Cada vez mais fica explicitada a necessidade
de os profissionais se aprofundarem e estudarem para desenvolver um
trabalho consciente e responsável. Constata-se, no entanto, que a formação
continuada deles está dependendo muito mais de uma mobilização pessoal
do que de um investimento por parte das escolas. No caso da rede pública, o
coordenador assume seu cargo mediante concurso, sendo que na rede
estadual, ele não precisa necessariamente ser pedagogo. Na rede particular,
normalmente, esse cargo é assumido devido à competência desse
profissional, avaliada de acordo com os critérios da escola, e não está
necessariamente relacionado à existência do diploma específico. Isso revela
que a formação inicial do coordenador (talvez por sua precariedade) não
influi na escolha do profissional feita pelas escolas. [...] Com a recente
proposta de reformulação do curso de Pedagogia, pode-se pensar numa
possibilidade de melhora no que se refere à formação inicial [...].
Certamente, o coordenador tem muito a dizer sobre suas necessidades, desde
que lhe seja dado espaço para isso. A questão da legitimidade de seu papel
passa também por um processo de profissionalização, entendido como a
ruptura de uma postura formal e formalizada, para uma postura de
investigação e descoberta. As estruturas administrativas (estaduais,
municipais e particulares) poderiam contribuir para a rediscussão dessa
questão. (CLEMENTI, 2005, p. 63)

Embora na Rede Municipal de Ensino de São Paulo exista a exigência da habilitação em pedagogia para o exercício da função de coordenador pedagógico, essa formação não garante um conhecimento que dê conta da complexidade da atividade pedagógica nas escolas. Tal perspectiva requer desse profissional um compromisso com a própria formação contínua.

Mate (2005), ao refletir sobre a identidade do PCP apresenta aspectos da atividade desse profissional, também observados na atuação do coordenador na Rede Municipal de 
Educação de São Paulo e traz, ainda que não textualmente, a idéia da formação contínua como espaço de busca e de envolvimento pessoal voltada para o desenvolvimento da prática profissional e para construção de uma identidade profissional:

\begin{abstract}
Elas [as práticas da coordenação] estão se fazendo mediante um aprendizado local, com indagações e buscas de respostas a problemas gerados no cotidiano das escolas. Essas indagações e buscas começam a se explicitar nos encontros de PCPs (oficiais ou não), em que a troca de experiências passa a ter um significado especial, em que a escuta do outro também adquire um sentido de aprendizado. Enfim o falar e o ouvir sobre as experiências passam a fazer parte constitutivas dos projetos em (re)construção, de modo que a busca, o contato e o diálogo com diferentes referenciais teóricos brotam do desejo de compreensão e respostas para as perguntas e angústias geradas nos espaços de trabalho. (MATE, 2005, p. 18, inclusão nossa entre colchetes)
\end{abstract}

Então, quando se trata da perspectiva de quais saberes sustentam a prática do coordenador, é perceptível certo sincretismo de natureza pragmática, biográfica e bibliográfica, vinculado à pessoa do coordenador e suas muitas experiências pessoais, profissionais e formativas. O quadro que segue ajuda a visualizar esse processo.

\title{
Complexidade da formação do coordenador pedagógico
}

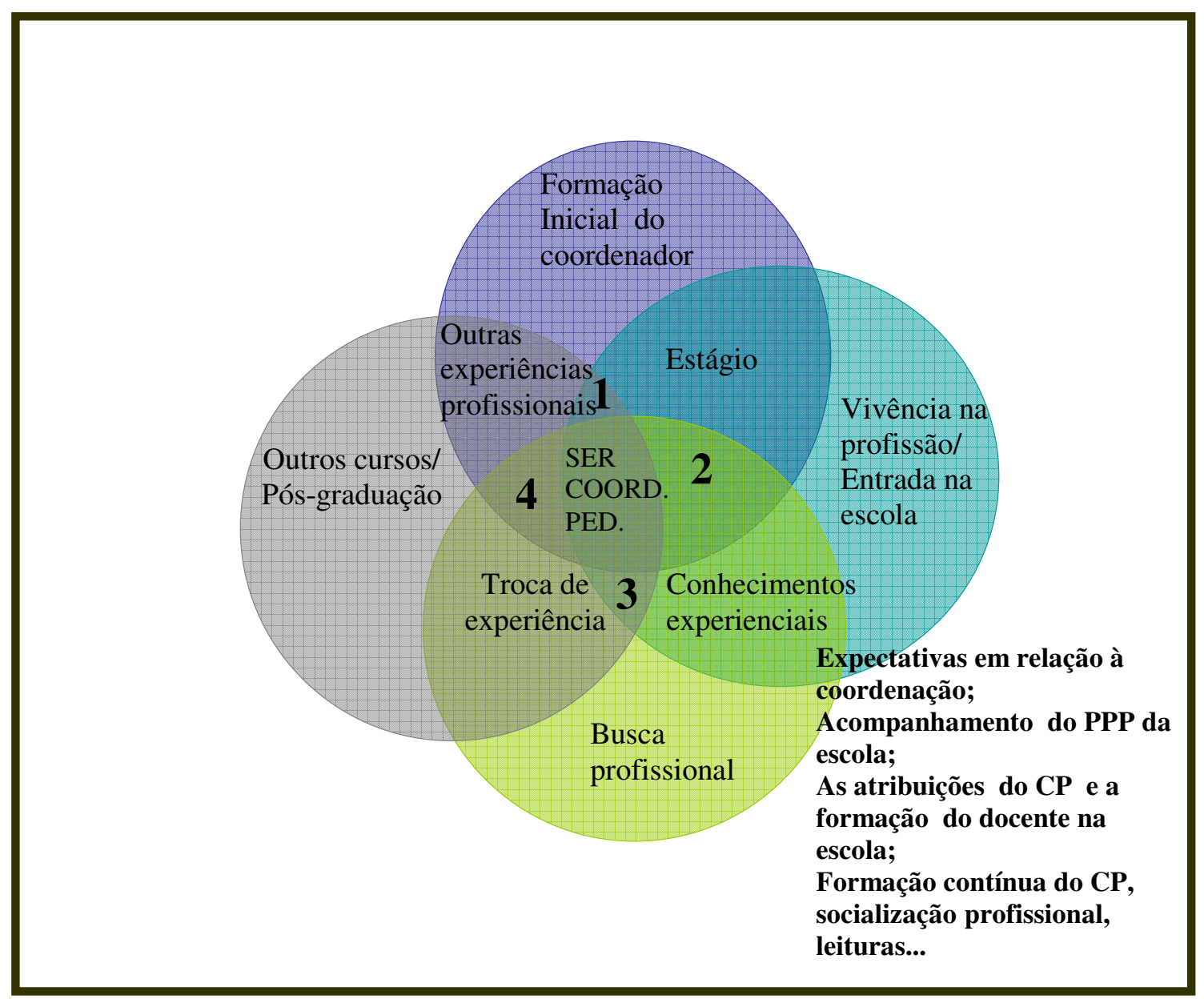


Quadro 05. Elaborado a partir dos dados da pesquisa e da bibliografia consultada

Ser coordenador pedagógico significa estar imbricado a um emaranhado de situações que o forma continuamente e orienta as suas escolhas, suas atitudes e sua posições frente à formação dos professores na escola. Os relatos revelam profissionais que passaram pela formação inicial, mas foi no início da profissão que foram descobrindo-se como formador, ou seja, coordenador/formador na escola. A marca dessa formação contínua do coordenador revela-se em histórias pessoais, que desembocaram na pós-graduação ou na mudança de função, de coordenadora para diretora ou supervisora. As escolhas pessoais, profissionais e de formação foram norteando a vida dessas educadoras e as constituindo na profissão, influenciando de forma peremptória o modo de ser na profissão, conforme ilustrado no quadro anterior. Rogério (2008, p. 178) faz uma análise desse processo. Tomando como referência o professor, suas idéias corroboram essa reflexão:

[...] entendemos o desenvolvimento profissional como um processo que se inicia no momento em que o professor começa a exercer a profissão, e que não tem prazo específico para terminar. Esse processo, que é inerente ao exercício da docência, sofre influência das experiências vivenciadas pelas professoras ao longo de suas trajetórias profissionais. Essas experiências são oriundas de relações estabelecidas com cada sala de aula em que o professor esteve trabalhando, de cursos de formação contínua, de 'trocas de saberes' da prática entre os colegas professores e de reflexões realizadas a partir de tudo isso. Todos esses aspectos constitutivos da docência vão sendo articulados, hierarquizados e selecionados ao longo da carreira na confluência com as condições objetivas de trabalho presentes na rede de ensino e na escola. Acreditamos, então, que o desenvolvimento profissional influencia diretamente os modos de ser dessas professoras.

Durante a pesquisa, as coordenadoras pedagógicas manifestaram a compreensão da formação contínua como a grande orientadora do trabalho na escola e da profissão, sendo considerada elemento fundamental na profissionalização desse educador.

No quadro que segue, as categorias apresentadas revelam elementos que, na perspectiva das coordenadoras, promovem o desenvolvimento desse profissional. Nesta análise, a coincidência entre os relatos nas entrevistas e a reflexão dos autores citados evidenciam uma preocupação com os aspectos estruturantes da atuação da coordenação 
pedagógica. As coordenadoras atribuem a sua profissionalidade a aspectos posteriores à formação inicial, ou seja, a busca pessoal, as trocas entre as coordenadoras, as vivências em outras funções e a participação em cursos diversos de escolha pessoal. O que se destaca na investigação é a situação ativa desses profissionais diante de sua própria formação e, especialmente, na produção de saídas para os problemas decorrentes dessa prática.

\section{A formação do coordenador, um entrecruzamento de experiências}

\begin{tabular}{|c|c|}
\hline $\begin{array}{l}\text { A BUSCA } \\
\text { PESSOAL }\end{array}$ & $\begin{array}{l}\text { "O aprender na prática, na minha opinião, implica em inquietação, porque tem } \\
\text { muitas coisas na escola que você percebe que não estão dando certo [...], mas se } \\
\text { você olhar o que não estiver dando certo como algo que lhe incomode, então } \\
\text { pode tentar algo para dar certo, isso é o aprender na prática". (COORD. MARIA } \\
\text { VITÓRIA) } \\
\text { "[...] o processo foi construído assim, na raça, [...] observando idéias } \\
\text { interessantes, porque não posso dizer que a formação inicial tenha ajudado de } \\
\text { fato [...]". (COORD.MARIA STELLA) }\end{array}$ \\
\hline \multirow[t]{2}{*}{$\begin{array}{c}\text { OS CURSOS } \\
\text { OFERECIDOS }\end{array}$} & $\begin{array}{l}\text { "Foi realmente na prática, e nessa prática o que ajudou, na minha opinião, foram } \\
\text { os cursos oferecidos pelas administrações. Quando ingressei em 2001, já era o } \\
\text { PT que estava aqui, mas, para mim, independente de quem estava na } \\
\text { administração, os cursos oferecidos ajudaram, pois quando entrei no cargo eu } \\
\text { não tinha bem claro o que tinha que fazer, ficava meio perdida [...]". (COORD. } \\
\text { MARIA VITÓRIA) } \\
\text { "Os primeiros cursos de formação contínua foram bons, deu para tirar algumas } \\
\text { coisas que me ajudaram". (COORD. MARIA STELLA) } \\
\text { "Eu me lembro que os supervisores começaram a montar grupos de formação } \\
\text { com os coordenadores, uma vez ao mês. [...] um supervisor que tinha cinco } \\
\text { EMEIs, reunia as cinco e discutia um assunto, nós montamos um projeto com } \\
\text { alguns temas que eram de maior desconhecimento ou dificuldades nossa [...], nós } \\
\text { é que organizávamos o projeto, o supervisor só propiciava o encontro.[...] Depois } \\
\text { nós montamos um curso à parte e passamos a pagar uma formadora e nos } \\
\text { reuníamos na casa de uma das colegas para estudar, foi o que ajudou, porque } \\
\text { não tínhamos uma formação da administração". (COORD. MARIA LEDA) } \\
\text { "Toda formação que fui tendo foi por minha conta. Fiz o mestrado e o doutorado. } \\
\text { Um ou outro curso, foi tudo interesse meu. Eu gosto de estudar e eu nunca deixei } \\
\text { de ser professora.[...] Na rede municipal quando eu entrei, foi na época do Maluf, } \\
\text { teve um curso para o coordenador pedagógico na USP e eu fiz aquele curso". } \\
\text { (COORD. MARIA AUGUSTA) }\end{array}$ \\
\hline & $\begin{array}{l}\text { "Outra coisa que ajudou muito foi a conversa com a minha colega de função, a } \\
\text { gente ia para os cursos e trocava, conversava e nessas conversas a gente foi } \\
\text { crescendo enquanto profissional, [...] a ajuda da minha colega foi muito } \\
\text { importante [...]". (COORD. MARIA VITÓRIA) } \\
\text { "[...] fomos aprendendo aos poucos, nos momentos das reuniões, na conversa }\end{array}$ \\
\hline
\end{tabular}




\begin{tabular}{|c|c|}
\hline $\begin{array}{c}\text { AS TROCAS COM } \\
\text { OUTRA CP }\end{array}$ & $\begin{array}{l}\text { com outros mais experientes". (COORD. MARIA STELLA) } \\
\text { "A sorte é que como tinha a outra coordenadora, muita coisa ela agilizou porque } \\
\text { ela tinha experiência. Na escola de ensino fundamental tem dois coordenadores e } \\
\text { ela acabou me ajudando um pouco nessa questão da rotina da coordenação no } \\
\text { ensino fundamental. Foi o que ajudou". (COORD. MARIA LEDA) } \\
\text { "Então foi bom (referindo-se ao curso para o coordenador pedagógico oferecido } \\
\text { na USP), mas não acrescentou muito em virtude da minha prática como } \\
\text { professora e coordenadora, pelo fato de sempre ter estudado, foi bom pela troca } \\
\text { com o grupo". (COORD.MARIA AUGUSTA) }\end{array}$ \\
\hline $\begin{array}{c}\text { A VIVÊNCIA EM } \\
\text { OUTRAS } \\
\text { FUNÇÕES }\end{array}$ & $\begin{array}{l}\text { "[...] fiz o concurso para coordenador e comecei a trabalhar [...] achei que foi } \\
\text { importante ter trabalhado em sala de aula pra ter a visão ( do trabalho docente) e } \\
\text { entrei no cargo de coordenador com a visão de professor. Até hoje, eu sou uma } \\
\text { defensora do professor, porque eu sempre me senti como professor, sei as } \\
\text { dificuldades que ele tem e me sinto mais professora do que outra coisa na } \\
\text { escola". (COORD. MARIA VITÓRIA) } \\
\text { "Eu trabalhava com formação, e ali era muito bacana porque era formação } \\
\text { mesmo [...]. Gostei muito dessa experiência. Então veio a oportunidade de ser } \\
\text { coordenadora, como já havia tido a experiência anterior, então eu pensei que } \\
\text { seria uma coisa legal [...] Mas dentro da escola, a gente vê que tem outras } \\
\text { nuances, outras coisas que vêm interferindo no trabalho". (COORD. MARIA } \\
\text { STELLA) } \\
\text { "Eu acompanhava muito os alunos no estágio e estava aprendendo a ser } \\
\text { coordenadora pedagógica porque estava orientando o trabalho deles, dos futuros } \\
\text { professores. E quando os professores me indicaram para ser coordenadora } \\
\text { pedagógica, eu ainda trabalhava no magistério, e sempre valorizei essa questão } \\
\text { do estágio, da prática de acompanhar os alunos, da discussão com as turmas e } \\
\text { acho que isso despertou o olhar dos meus colegas professores". (COORD. } \\
\text { MARIA AUGUSTA) }\end{array}$ \\
\hline $\begin{array}{c}\text { MODOS DE } \\
\text { ATUAÇÃO DO } \\
\text { COORDENADOR }\end{array}$ & $\begin{array}{l}\text { "Na primeira escola em que eu trabalhei como professora, ter ou não ter } \\
\text { coordenador era a mesma coisa, porque só havia contato com o coordenador no } \\
\text { Conselho de Classe e naquela época eu já fazia JEI na escola, isto foi no ano de } \\
\text { 1996. Para não dizer que não houve nada, havia a necessidade de um projeto e o } \\
\text { coordenador chegou com o projeto já pronto, perguntando o que nós achávamos, } \\
\text { pois o tema era as relações, chamava-se 'Conviver'. Ele apresentou o projeto, } \\
\text { que estava interessante, mas não havia sido elaborado pelo grupo. Concordamos } \\
\text { em desenvolver o projeto, mas pensamos em mudar o nome, então fizemos uma } \\
\text { votação e sugerimos um outro nome. No final o nome não foi mudado.Depois, na } \\
\text { outra escola em que eu fiquei cinco anos, a coordenadora era uma excelente } \\
\text { pessoa, fazia um trabalho muito bom com os alunos, mas com o professor, } \\
\text { profissionalmente, deixou a desejar". (COORD. MARIA VITÓRIA) } \\
\text { "Nós acabamos seguindo uma linha. Nos grupos de JEI nós discutimos, } \\
\text { levantamos os temas, ouvimos as diferentes opiniões. As discussões não são } \\
\text { impostas, algo que o coordenador traz e todo mundo diz amém. As JEIs dão } \\
\text { trabalho porque sabemos que vamos ter que construir e administrar as opiniões, o, } \\
\text { que pensa A e o que pensa B e vem o terceiro que pensa C, e dá trabalho". } \\
\text { (COORD. MARIA STELLA) }\end{array}$ \\
\hline
\end{tabular}




\begin{tabular}{|c|c|}
\hline & $\begin{array}{l}\text { "Já trabalhei com coordenadores que não eram líderes e que as coisas não } \\
\text { aconteciam. É preciso autoridade, essa questão de ser autoridade na escola não } \\
\text { significa ser autoritário, isto, também é algo que a gente conquista, mas eu acho } \\
\text { que isso é o primordial para a formação do coordenador". (COORD. MARIA } \\
\text { LEDA) } \\
\text { "Eu não entendo coordenação dessa forma, ficar mandando as pessoas fazerem } \\
\text { algo. Eu acho que ela existe no sentido de estabelecer parcerias. Eu senti muitas } \\
\text { dificuldades de trabalhar com os professores da escola pública porque há um } \\
\text { modelo de coordenador pedagógico dominante, por isso que os professores não } \\
\text { gostam, falam muito mal do coordenador pedagógico [...]". (COORD. MARIA } \\
\text { AUGUSTA) }\end{array}$ \\
\hline $\begin{array}{c}\text { AS } \\
\text { EXPECTATIVAS } \\
\text { DOS } \\
\text { PROFESSORES } \\
\text { EM RELAÇÃO AO } \\
\text { TRABALHO DO } \\
\text { COORDENADOR }\end{array}$ & $\begin{array}{l}\text { "[...] o professor tem suas dificuldades em sala de aula e no momento em que ele } \\
\text { consegue estar junto com seus pares, tem uma necessidade de estar falando dos } \\
\text { pontos difíceis. [...]. Ele não para mais de falar disso, ele quer falar de } \\
\text { indisciplina, ele quer falar que a sala está muito cheia, que o aluno não tem } \\
\text { interesse, ele quer só falar das dificuldades do processo educativo, isso é o ponto } \\
\text { que mais atrapalha o processo de formação". (COORD. MARIA VITÓRIA) } \\
\text { "[...] às vezes eu acho que o CP é aquela pessoa com a qual o professor quer } \\
\text { desabafar, contar as mazelas. As expectativas são mais nesse sentido, de quando } \\
\text { o professor tem um problema [...]. Eles querem que o CP vá e resolva e não que } \\
\text { problematize a sala de aula, o conteúdo, a metodologia. Tem reuniões } \\
\text { pedagógicas e de JEI que a gente tem que vir preparada porque os professores } \\
\text { relatam os problemas e esperam uma resposta direta da coordenação, uma } \\
\text { solução". (COORD. MARIA STELLA) } \\
\text { "[...] o que eu mais estranhei foram as questões das relações. Eu tinha muitos } \\
\text { problemas na outra escola com relacionamento porque tinha um grupo de } \\
\text { professores muito antigo e na mesma escola há muitos anos, havia professor com } \\
22 \text { anos na mesma escola. Eu vim para cá na primeira remoção, a escola vai fazer } \\
\text { três anos, isso foi muito positivo, apesar de eu ter um grupo muito maior do que } \\
\text { eu tinha antes, é um grupo mais receptível, mais acolhedor, um pessoal que está } \\
\text { com vontade de fazer um trabalho, pode não saber muita coisa, mas corre atrás. } \\
\text { Na outra escola todos sabiam tudo". (COORD. MARIA LEDA) } \\
\text { "[...] eu também aprendi isso na escola pública, eles (os professores) querem um } \\
\text { coordenador que manda para poder dizer, quando o aluno não aprender, que } \\
\text { gostaria de ter feito diferente, mas foi o coordenador quem mandou”. (COORD. } \\
\text { MARIA AUGUSTA) }\end{array}$ \\
\hline & $\begin{array}{l}\text { "O coordenador tem essa função de gestor, assim como o diretor. Mas a ênfase, } \\
\text { como o próprio nome do cargo, é o pedagógico. Na prefeitura nós ainda temos a } \\
\text { vantagem do horário coletivo e esse horário permite fazer muita coisa [...]. Tem } \\
\text { dia que você sai da JEI meio frustrada, mas tem dia que você sai com a sensação } \\
\text { de plenitude, [...] é um trabalho gratificante, que eu não vejo em outras funções". } \\
\text { (COORD. MARIA VITÓRIA) } \\
\text { "[...] se eu não priorizar a formação ninguém vai fazer, mas tem as outras } \\
\text { atribuições, como alguns atendimentos, que outras pessoas podem fazer, [...] A } \\
\text { existência do coordenador pedagógico se justifica por isso, é pensando em }\end{array}$ \\
\hline
\end{tabular}




\begin{tabular}{|c|l|}
\hline $\begin{array}{c}\text { O PAPEL DO } \\
\text { COORDENADOR }\end{array}$ & $\begin{array}{l}\text { alguém que está ali pela formação, se não fizer isso fica muito complicado". } \\
\text { (COORD.MARIA STELLA) }\end{array}$ \\
& $\begin{array}{l}\text { "[...] é um papel importantíssimo, principalmente na questão da formação desses } \\
\text { profissionais que estão aqui, garantir um trabalho de qualidade na educação } \\
\text { infantil, na escola pública. Acho que é o primordial [...] investir na formação } \\
\text { desses profissionais, até porque eles são muito heterogêneos, pessoas com } \\
\text { experiências, pessoas que estão entrando, pessoas que nunca trabalharam na } \\
\text { educação infantil, pessoas que estão na rede há pouco tempo, outras há muito } \\
\text { tempo". (COORD. MARIA LEDA) } \\
\text { "Na verdade, o papel do coordenador é de intervenção, se não for isto, para que } \\
\text { precisariam de mim aqui". (COORD.MARIA LEDA) } \\
\text { "O coordenador tem um papel fundamental que é o de estar intervindo junto aos } \\
\text { professores [...]". (COORD.MARIA AUGUSTA) }\end{array}$ \\
\hline
\end{tabular}

Quadro 06. Elaborado a partir da entrevista dada pelas coordenadoras

As categorias construídas a partir da interlocução com as participantes da pesquisa, em consonância com o referencial teórico utilizado ao longo da elaboração deste trabalho, apresentam elementos que corroboram a discussão da formação contínua dos coordenadores pedagógicos como constituindo-se num complexo entrecruzamento de experiências que tem como ponto de partida o ingresso no/na cargo/função de coordenador.

Guimarães (2006), ao analisar o trabalho de socialização profissional dos professores iniciantes, entende-o como uma fase de extrema importância para a profissionalização docente. Os depoimentos das coordenadoras também vão apontar esse período inicial de socialização profissional, que se caracteriza pela busca pessoal do sentido dessa atividade, quer por meio de consulta a profissionais mais experientes, quer pela busca de cursos de formação contínua. A definição de socialização profissional elaborada pelo autor favorece a articulação com o sentido que lhe é atribuído nesse trabalho, que é de explicitá-la como o período de introdução na atividade de coordenação que se caracteriza pela busca de um saber e de um saber-fazer eficientes. Diz ele:

Socialização profissional [...] é o processo através do qual as pessoas constroem valores, atitudes, conhecimentos e habilidades que lhes permitem e justificam ser e estar em uma determinada profissão. É um processo de concretização dos ideais profissionais. Poderíamos arriscar a dizer que, sob um aspecto mais objetivo, a socialização profissional constitui-se no processo de traduzir em práticas profissionais os conhecimentos inerentes à profissão. E, sob o aspecto subjetivo, constitui-se na efetiva identificação e adesão à profissão. (GUIMARAES, 2006, p.8) 
Essas experiências arquitetam uma segurança profissional em função da reformulação de alguns saberes e da elaboração de outros que orientam a atividade do coordenador.

De modo geral, o que se observou foi o empenho das coordenadoras na busca por uma profissionalidade que lhes permitisse atuar de forma competente na função, assim sendo, verificou-se a influência de aspectos objetivos como a busca pessoal que move o coordenador para resolução de uma determinada dificuldade; os cursos oferecidos pela gestão pública, entidades de classe e universidades que ampliam os conhecimentos e habilidades sobre o trabalho na escola; as trocas de experiências com pares, normalmente mais experientes; e $a$ vivência na função que impõe escolhas, decisões e organização do trabalho. Também contribuem nesse processo de ordem mais subjetiva relacionados à opção ou transição entre modos de ser coordenador, construídos na relação com as experiências anteriores, $a$ percepção do que os professores esperam do trabalho desse profissional e as implicações desse fator nas tomadas de decisões e, finalmente, aspectos relativos à compreensão do papel do coordenador pedagógico que, mesmo estando num processo de re-elaboração, evidenciam o caminho pedagógico trilhado pelas unidades educativas, bem como indicam posicionamentos em relação à condução da formação contínua do docente centrada na escola.

A seguir a proposta é desenrolar esse emaranhado numa análise que possibilite uma aproximação e uma compreensão dessas influências na configuração da coordenação pedagógica,

A busca pessoal foi um dos primeiros elementos apontados pelas coordenadoras como tendo caráter formativo. Essa projeção normalmente está associada às demandas dessa atividade e está relacionada às tentativas de ação profissional, aos acertos e aos erros. Na fala das coordenadoras, conforme organizadas no quadro anterior, essa tendência aparece assim: 'aprendi na prática', 'foi uma construção empírica', 'foi observando, estudando'. Esses depoimentos evidenciam o investimento de tempo, energia e dinheiro na intenção de exercer bem a função. Apontam também para uma ineficácia da formação inicial e uma falta de investimento do poder público na formação desses profissionais. Segundo Clementi (2005, p. 64), a busca pessoal não é suficiente para o exercício reflexivo da coordenação pedagógica:

Muitos coordenadores manifestam iniciativas pessoais de aprofundamento teórico, de envolvimento com suas práticas nas escolas, preocupação diante dos problemas com os quais deparam e, ainda assim, mesmo demonstrando empenho e envolvimento, muitas vezes assumem uma atitude de conformismo diante das insatisfações que sentem, em vez de tentar revertêlas. 
Conforme ressalta a autora, ainda que exista um forte envolvimento pessoal, é possível que este esforço não produza nem o conhecimento necessário, nem a força para lutar contra as dificuldades que geram insatisfação, uma delas pode ser a ausência de uma formação que considere as necessidades do coordenador. Outros aspectos são o caráter de isolamento que pode ser decorrente dessa procura individual, a falta de espaços coletivos e a inflação de trabalho que imobiliza o profissional em sua unidade, não lhe permitindo compartilhar com outros (seus pares) suas dúvidas. Ilustra essa idéia o depoimento que segue:

Quando ingressei no cargo, não tive outras coordenadoras em quem me espelhar [...]. Foi realmente na prática, [...] pois eu não tinha bem claro o que tinha que fazer, ficava meio perdida, porque todo mundo que me procurava trazia uma demanda de trabalho, então você fica por um tempo tentando resolver tudo [...]. (COORD MARIA VITÓRIA; grifo nosso)

Nesta perspectiva, destacamos que o profissional centrado em entender e atender as demandas da prática pode, ainda, incorrer num 'praticismo' frenético, que é a busca por responder satisfatoriamente às necessidades de todos na escola, isso lhe rouba o tempo para a reflexão crítica, a pesquisa, o estudo teórico e para atender questões específicas da coordenação pedagógica.

Os cursos de formação contínua são uma prática comum em todas as redes de ensino. Na última década, principalmente, tem se multiplicado o número de cursos voltados à coordenação pedagógica. Na Rede Municipal de Ensino de São Paulo, os cursos de formação, específicos para os coordenadores, associados à implementação de projetos de governo, são obrigatórios. A coordenadora Maria Augusta, que ingressou em 1996, foi convocada para um curso na FEUSP, nesse mesmo ano, especialmente organizado para atender o coordenador pedagógico. Mas, segundo ela, como o estudo já fazia parte da sua vida profissional e investia na sua formação, esse, particularmente, não trouxe uma contribuição significativa, a não ser a possibilidade de interação com os pares.

A coordenadora Maria Leda, que ingressou em 2000, relatou que o primeiro 'curso', uma assessoria paga por um grupo de coordenadoras recém-ingressantes, aconteceu movido por uma necessidade pessoal e, portanto, contribuiu para a construção de sua identidade, numa época que não havia formação institucional para os coordenadores. Posteriormente, os supervisores organizaram grupos de formação tentando suprir esta ausência e o foco deste trabalho estava na troca de experiência e no estudo. As coordenadoras Maria Vitória e Maria Stella ingressaram na mesma época, em 2002, e se beneficiaram, também, dos cursos 
oferecidos pela rede que problematizavam a função do coordenador pedagógico. Nesses casos, a oferta e a busca de cursos estão diretamente associadas ao acúmulo de saberes que auxiliem no exercício competente da profissão.

Garrido (2007), ao enfocar a importância do trabalho de formação desenvolvido no horário coletivo pelo professor-coordenador, faz uma análise da eficácia do uso deste espaço e o investimento da formação deste profissional, situação que podemos aplicar ao trabalho desenvolvido pelo coordenador pedagógico. Segundo a autora:

É preciso investir nesse espaço, e isso significa que é preciso investir na formação do professor-coordenador, na medida em que ele é o agente estimulador e articulador desse processo. Para tanto, é preciso que ele, figura isolada em sua unidade escolar, tenha um espaço coletivo e formador, análogo ao HTPC, no qual possa apresentar as dificuldades inerentes à sua nova função, partilhar angústias, refletir sobre sua prática como coordenador, trocar experiências... crescer profissionalmente, para poder exercer de forma plena sua função formadora e promotora do projeto pedagógico. (GARRIDO, 2007, p. 11)

As trocas de experiências com outras coordenadoras foram apontadas por todas as coordenadoras entrevistadas como um elemento fundamental na formação do coordenador pedagógico, principalmente do coordenador iniciante.

Nas vivências relatadas, as trocas de experiências aconteciam nos cursos de formação contínua, no próprio local de trabalho quando havia outra coordenadora, em contatos telefônicos, nas reuniões de que participavam nas diretorias de educação, onde houvesse oportunidade de conversa. Nesses casos, a troca era direta. Perguntava-se o que se desejava saber e a resposta do outro trazia elementos para se pensar a própria realidade.

Observa-se que essa troca de experiência vivenciada pelas coordenadoras não era uma modalidade formadora sistemática, mas sim uma ação imbricada com a busca pessoal e com as relações que se estabeleciam no exercício da função. Tal perspectiva apresentava um caráter formativo, mas não se constituía, por si só, em uma construção pautada na reflexão crítica sobre os saberes e fazeres socializados.

As coordenadoras, também, assinalaram a vivência em outras funções educativas como elemento de contribuição para o exercício da coordenação. Experiências diversas como professoras em diferentes redes de ensino, assistentes técnico-pedagógico, docentes universitárias e coordenadoras em outra rede contribuíram para as entrevistadas elaborarem seus perfis profissionais, agregando valores e habilidades ao modo de ser coordenadora e de conduzir a formação contínua na escola. Rogério (2008, p.176), ao analisar a construção da 
carreira docente, faz uma afirmação que ajuda na compreensão da influência das experiências profissionais no desenvolvimento profissional do coordenador pedagógico:

Dito de outro modo, o conjunto das experiências vivenciadas pelo professor nas diferentes carreiras das redes de ensino nos leva a formular uma compreensão de carreira que leve em conta tanto a vertente institucional desta quanto a vertente pessoal. A vertente institucional diz respeito ao que está posto nos Estatutos de legitimação da carreira profissional do professor e a vertente pessoal refere-se às possibilidades e às necessidades de vida de cada professor. Não há como entender o desenvolvimento profissional de um professor que circulou por mais de uma rede de ensino delimitando sua carreira a uma única rede. Nessa direção, a carreira como percurso profissional é diferente da carreira estabelecida por um Estatuto, mas ambas ajudam a formar a carreira do magistério vivenciada por cada professor.

A convergência dos depoimentos revela que a figura do coordenador não está dissociada de suas experiências profissionais e de seu posicionamento na sociedade, portanto, sua atividade está de certa forma condicionada a essas múltiplas experiências. Assim, parafraseando Nóvoa (1992), a formação contínua do coordenador também produz a vida, a profissão e a escola, tornando impossível separar, na ação, a pessoa e o profissional.

Outro aspecto destacado pelas coordenadoras e que contribuiu para a constituição de sua subjetividade foi a consciência de modos (diversos) de atuação do coordenador. A forma de atuar na profissão, conforme relato das participantes, revela uma adesão maior ou menor a um modo de ser coordenadora.

Alguns modos foram sendo burilados pelas experiências vividas na posição de professor sob a orientação de coordenadores pedagógicos. A experiência da coordenadora Maria Vitória, relatada no quadro anterior, torna-se emblemática da representação do tipo de coordenação que ela não queria desenvolver, nem autoritária e nem desfocada, pois ambas são caracterizadas como uma falha profissional.

A coordenadora Maria Leda faz uma distinção entre liderança/autoridade e autoritarismo, revelando o que aprendeu com essas experiências, ou seja, que é possível ser uma líder sem ser autoritária. Quando esse aspecto não é considerado, segundo ela, 'as coisas' (os projetos, a formação contínua do docente, o coletivo da equipe, as intervenções críticas, etc) não acontecem na escola. 
Os depoimentos mostram que as coordenadoras exercem seu trabalho mediado por uma linha de pensamento, uma idéia de atuação profissional. Esse modo de ser, que orienta o trabalho dessas profissionais, pode caracterizar-se por uma produção coletiva, se a equipe for madura para 'administrar' as opiniões e as discordâncias. Contudo, pode configurar-se como a prática de uma idéia dominante e pouco reflexiva sobre a atuação desse profissional, situação ilustrada pela coordenadora Maria Augusta quando afirma que o coordenador pode ser visto como uma pessoa que manda, que controla e que cobra.

Os múltiplos 'jeitos’ de ser coordenador pedagógico estão associados: à formação, à competência profissional, ao receio do trabalho com professores, ao medo de falhar frente aos superiores, à organização da escola, à relação com a direção e equipe docente, às crenças pessoais, à cultura da escola etc, mas será sempre uma opção que, grosso modo, penderá para uma ação autoritária ou partilhada e coletiva.

A consciência de uma atividade voltada para diferentes fins, como afirmam as coordenadoras em seus depoimentos, revela a diversidade de atuação desse profissional que se manifesta na forma de vivenciar a sua função, inclusive, a formação na escola.

A formação contínua do coordenador sofre influências das expectativas do professor em relação ao coordenador. Lidar com e liderar um grupo é algo que depende de basicamente dois fatores - uma autoridade instituída e uma autoridade desenvolvida.

É verdade que um grupo pode configurar-se em uma força negativa que despreza tudo o que não conhece ou com o qual não concorda. Administrar essa experiência é algo que (de)forma o coordenador pedagógico. Assim, diante daqueles que só querem reclamar das dificuldades, desabafar as mazelas e que esperam do coordenador uma solução, ou ele se amolda às exigências do grupo e perde o seu papel de problematizador e propositor, ou ele ouve e devolve para o grupo o problema, de modo reflexivo e crítico, investindo em uma atitude mais ativa.

A expectativa dos professores pode direcionar o trabalho da coordenação e torná-lo mais fácil ou mais difícil. O que fazer quando todos acreditam saber tudo e se recusam a aprender? Esses são aspectos que fazem parte do trabalho e da profissionalidade do coordenador, que dependerá da articulação de conhecimentos pedagógicos e de uma boa relação com a equipe técnica da escola.

A formação contínua do coordenador passa também pela construção do papel do coordenador pedagógico. Os relatos dos coordenadores apontam a transitoriedade desse papel na história da Rede Municipal de Ensino de São Paulo. Assim, as constantes reformulações acerca da função 'principal' desse profissional têm se caracterizado por uma 
reflexão que aborda o coordenador em dois aspectos: pelas opções metodológicas que a definição desse papel promove e pela própria organização do trabalho na escola.

Desta forma, o coordenador, entendido como gestor, cuja ênfase está nas discussões pedagógicas, conforme definido pela coordenadora Maria Vitória no quadro anterior, tem uma série de atribuições que começa pelo acompanhamento das atividades pedagógico-didáticas e curriculares com ênfase na sala de aula até a priorização dos processos formativos na escola, objetivando o aprimoramento da ação pedagógica. Nos dois aspectos, o que se destaca é a responsabilidade pela intervenção, coerente, positiva, reflexiva e crítica, para o avanço da ação profissional dos professores, que se constitui em um saber que não está descrito em nenhum manual, construído num processo de formação contínua que precisa considerar a escola e seus educadores como situados num tempo/espaço histórico específico.

A formação contínua do coordenador é, de fato, algo muito emaranhado e com diversos lados. Um deles tem sido vivenciado pelos coordenadores pedagógicos que atuam, principalmente, nas EMEIs e CEIs desde 2006, quando foram incluídos num processo de formação que tem se caracterizado por sua continuidade e sistematização ${ }^{50}$, visando atender as especificidades da coordenação nesse nível educacional. $\mathrm{Na}$ introdução do documento ' $A$ Rede em rede: a formação continuada na educação infantil, fase I', é possível observar como o coordenador está sendo significado e os caminhos da formação proposta. Segundo o documento:

O parceiro institucionalmente proposto para cuidar dessa tarefa de formação docente continuada nas Unidades Educacionais é o Coordenador Pedagógico. Reconhecemos que o cotidiano apresenta inúmeras demandas que extrapolam as ações dos professores na relação direta com as crianças. Tais demandas se apresentam como problemas complexos, cuja resolução depende do olhar muito informado, capaz de estranhar o que se vê e se inquietar. A formação profissional não se encerra com a diplomação, mas se estende ao longo da vida, desafiada pelas experiências concretas vividas. Daí a importância de formação continuada a todos os professores, para estimular a renovação de saberes em ambientes de aprendizagem coletiva e automotivada. Esse é um dos papéis do CP [...]. O coordenador Pedagógico não é um mero gestor de sistemas, de práticas que dão certo e que sempre funcionaram. A especificidade do Coordenador

\footnotetext{
50 Os princípios que norteiam o trabalho pedagógico na rede municipal de Ensino de São Paulo têm sido sistematizados em publicações que são socializadas com os profissionais da rede. Especificamente, como síntese da formação oferecida ao coordenador pedagógico da educação infantil, foi elaborado o documento "A rede em rede: a formação continuada na educação infantil- fase I". Outros documentos foram organizados para sistematizar a implementação do "Programa Ler e Escrever- Prioridade na Escola Municipal”. Os que fazem uma referência direta à ação do coordenador são: "Guia de estudos para o horário coletivo de trabalho: subsídios para os coordenadores pedagógicos" e "Referencial de expectativa para o desenvolvimento da competência leitora e escritora no ciclo II do ensino fundamental, documentos que se destinam aos coordenadores de EMEFs.
} 
Pedagógico reside em sua capacidade de descontextualizar práticas cotidianas, compreender o que é mais geral nas tantas situações que envolvem a educação de crianças e a formação de adultos, transformar as queixas em bons problemas, congregar esforços para encontrar alternativas e, muitas vezes, inventar soluções. Por isso podemos dizer que o Coordenador Pedagógico é um dos profissionais mais estratégicos na formação continuada da equipe de professores e na construção de um trabalho pedagógico nas EMEIs e CEIs. (SME/DOT, 2007, p.11; grifo nosso)

O documento reconhece aquilo já apontado pelas coordenadoras entrevistadas, a multiplicidade de papéis, entre eles o de ouvinte das queixas docentes e o de intervenção do coordenador pedagógico sobre as práticas pedagógicas e na formação contínua da equipe docente das escolas. O material publicado visa contribuir com o coordenador pedagógico de modo que possam tomar decisões "[...] que referem-se às melhores formas de mediar aprendizagens que contribuam para os avanços das crianças.” (SME/DOT, 2007, p. 12).

Todas essas experiências, conjuntamente e num determinado tempo, vão reelaborando o nexo da ação do coordenador pedagógico e moldando um determinado perfil de coordenação. Certo é que cada vez mais a coordenação pedagógica nas escolas públicas vai assumindo a formação centrada na escola como algo inerente ao seu trabalho, que receberá influência das diversas experiências vividas por esse profissional.

\section{O período de iniciação profissional do coordenador pedagógico: um terreno fértil para a autoformação}

Embora entenda-se que a formação dos coordenadores iniciantes esteja relacionada com a formação contínua desses profissionais, os depoimentos destacaram o período inicial na função/no cargo como conturbado, repleto de angústias e inseguranças, reforçando a importância do acompanhamento desses profissionais nessa fase inicial.

Embora já haja essa preocupação em relação ao professor iniciante (MARCELO GARCIA, 1999), esse cuidado parece não existir em relação ao coordenador iniciante. Há um silêncio dos meios acadêmicos sobre esta questão, talvez porque a expansão da ação do coordenador pedagógico, na forma como está configurada na atualidade, tenha acontecido no final da década de 1980, e a partir daí vem se re-configurando. Outra possibilidade é a 
associação que alguns fazem entre o cargo de professor e o de coordenador, como se, para o exercício do segundo, apenas a experiência docente pudesse ajudá-lo.

Um professor experiente não se transformará, num passe de mágica, num coordenador experiente, são funções diferentes que exigem uma profissionalização e uma profissionalidade pedagógica. Se existe uma especificidade nesta função que também está condicionada às diferentes redes de ensino, então quais têm sido os investimentos nos primeiros anos da coordenação pedagógica, na fase de iniciação do trabalho? Por outro lado, como são considerados os conhecimentos dos coordenadores experientes?

Os coordenadores neste período inicial procuram estabelecer nexos entre os seus conhecimentos sobre a ação da coordenação pedagógica e as informações decorrentes das inúmeras experiências de socialização profissional, o que não lhes garante de imediato uma ação segura e eficiente. Porém, essas experiências favorecem a criação de zonas de intersecção entre os saberes de quem assume a função, os coordenadores mais experientes e os cursos que discorrem sobre o coordenador, que normalmente elaboram uma identidade inicial que vai se redefinindo à medida que o ser coordenador vai assumindo contornos nítidos.

A reflexão feita pelos entrevistados sobre esse período de trabalho do coordenador apontou alguns aspectos que podem influir na forma de exercício da coordenação, na sua estruturação e na construção de uma identidade. São eles: a insegurança, o medo e o processo de ser coordenador; o choque com a realidade complexa da escola; o processo de aprender as normas, valores e condutas - a cultura da escola. Tais aspectos serão comentados a seguir.

\subsection{A insegurança, o medo e o processo de se constituir coordenador}

A literatura especializada (CAVACO,1995; MARCELO GARCIA, 1999) tem dado relevo ao período de iniciação profissional de professores, destacando que, embora esse período faça parte do desenvolvimento profissional, tem características próprias que requerem uma análise particularizada, sendo esses primeiros anos um tempo de intensa aprendizagem, de muita tensão e de construção de uma identidade profissional (MARCELO GARCIA,1999). Semelhantemente ao professor, o coordenador iniciante assume demandas novas de trabalho que requerem novos conhecimentos, a re-elaboração de sua identidade profissional e o equilíbrio das tensões advindas de uma nova atividade. 
Os depoimentos que seguem revelam claramente como este momento inicial da carreira traz uma série de desafios para o profissional que, mesmo com uma formação específica, tende a lidar no conjunto da atividade com diversos conhecimentos simultaneamente, além de se relacionar com personagens que desempenham papeis diversos e afins na trama que é o trabalho educativo na escola.

As coordenadoras Maria Stella e Maria Leda mostram certa concordância quanto às dificuldades vividas no início da coordenação pedagógica, apontam que o profissional fica sem entender o que está acontecendo, o que tem de fazer, a dinâmica de sua ação e ainda como as pessoas se aproveitam desta fase para aumentar ou atribuir novas demandas ao trabalho do coordenador:

[...] fui ser coordenadora em uma escola de ensino fundamental. Eu entrei em julho e fiquei seis meses nessa escola, na verdade, foram seis meses de observação de entendimento das coisas. Eu não sabia o que acontecia, não conhecia a dinâmica de uma escola de Ensino Fundamental [...] eu tive pessoas que me ajudaram, que iam me explicando as coisas. Eu me lembro quando chegaram os livros para a escolha dos livros didáticos, e eu via aquele material chegando e não entendia porque chegavam, até que um dos professores me disse que era para a escolha dos livros didáticos. Eu pensava que era doação de alguém. Nossa, era difícil, na verdade eu fiquei observando tentando entender [...], foi muito assustador esses seis meses. (COORD. MARIA LEDA, grifo nosso)

No início a gente chega e parece que todo mundo tem uma demanda para a coordenação. Você está no meio da JEI e alguém vem falar do telefone, isso é um processo de construção, no começo as pessoas interferiam muito, não entendiam que aquele era um espaço da coordenadora e dos professores e que aquilo era prioridade. (COORD. MARIA STELLA, grifo nosso)

Os coordenadores são vistos como pessoas que mandam, e eu nunca exerci a função de coordenação pedagógica nesta ótica. Aqui, até houve uma resistência e alguns professores demoraram para me entender, porque cobravam de mim este papel, esta postura. (COORD. MARIA AUGUSTA)

Os depoimentos revelam sentimentos complexos: dúvida, medo e inseguranças, fruto da pressão por resultados imediatos. Tal situação gera um alto grau de ansiedade, que longe de mobilizar um maior envolvimento, produz uma tensão que pode dificultar a adaptação do coordenador recém-ingressante, além de criar uma sensação de incompetência que desmobiliza, causa angústia e faz o profissional duvidar de sua própria capacidade. 
Outro aspecto importante é a resistência dos professores ao novo profissional que chega à escola. A coordenadora Maria Augusta aponta que, por questões conceituais a respeito do que deveria ser a ação do coordenador no momento do ingresso, enfrentou dificuldades na relação com os docentes. Essa coordenadora já havia exercido a função em outra rede de ensino, mesmo assim não nega que essas experiências podem levar o profissional à depressão e à desistência.

A solidão parece ser o sentimento dos primeiros tempos, como enfocada na fala da coordenadora Maria Vitória, fruto talvez do individualismo que impera. Mas, precisa ser superado pela integração do novo profissional à equipe, ajudando-o a atuar dentro da sua competência, à medida que conhece a cultura local:

\footnotetext{
Nos primeiros anos nós trazíamos tudo, teve até um pouco de resistência. Sabe como é, coordenador novo que começou agora [...] o coordenador anterior tinha uma prática aceita e a pessoa quando chega não tem aquela receptividade, $[. .$.$] não tem muitos vínculos. No primeiro ano, eu me senti$ muito sozinha no grupo de JEI, quando trazia um assunto para discutir, eu praticamente falava sozinha e até me cansava. Então, eu percebi que com o tempo nós fomos aceitas como profissionais. Eu sinto que hoje tenho parceiros, muitos professores que me ajudam [...]. (COORD. MARIA VITÓRIA)
}

Emoções e sensações como as descritas pelas coordenadoras não são produtivas. É sabido que todo início, num novo espaço de trabalho educacional, requer uma dedicação maior dos profissionais, quer ingressantes, quer veteranos, pois a atividade educativa tem exigências que estão associadas a uma cultura local, a um lugar específico e às relações interpessoais nesse contexto. Isso impõe como requisito da profissionalidade uma atitude adaptativa.

Além do indispensável apoio da equipe escolar, no caso específico do coordenador iniciante, é importante que a supervisão escolar de sistema conheça esse profissional e faça as mediações necessárias, inclusive orientando sobre aspectos singulares de sua prática. É necessário que esse coordenador seja apoiado em seu trabalho para que, sentindo-se amparado, possa desenvolvê-lo com menos dificuldades.

\subsection{O choque com a realidade complexa da escola}


Outro aspecto, ainda relacionado aos coordenadores iniciantes, diz respeito ao impacto no início da profissão entre o que se imagina do trabalho e o que de fato ele é. A realidade escolar, nas suas muitas dimensões, contradições e oposições, manifesta as possibilidades e impossibilidades desse trabalho. Nem sempre um profissional inexperiente é capaz de enxergar, numa realidade que impressiona pelos desafios, as possibilidades de um trabalho coerente e transformador. A coordenadora Maria Vitória em seu depoimento relata como enfrentou essa realidade.

Você tem que perceber qual é, de fato, sua função e o que você deve priorizar, você vai sempre continuar fazendo muitas coisas, mas qual é, de fato, a prioridade.[...] Nossa, eu sofri muito com isso, quando eu entrei aqui, eu queria muito resolver todos os problemas da escola, eu pastei mesmo, hoje estou num momento mais calma, continuo tentando resolver uma porção de coisa, mas não com o desespero inicial.

As coordenadoras, de modo geral, apontam como um aspecto dificultoso do trabalho, principalmente no início, a própria dinâmica de organização da escola e da rede de ensino. Um coordenador que chega a uma escola da Rede Municipal de Ensino de São Paulo encontra, atualmente, professores e alunos lutando contra as dificuldades pedagógicas, projetos de formação docente para organizar, grupos de professores (em JEIF) para acompanhar e um discurso sobre o trabalho coletivo, sobre a importância da reflexão-crítica do docente e sobre a gestão participativa. O que seria tudo isso? Como lidar com o aluno do ensino fundamental II (adolescente), quando a experiência profissional encontra-se toda na educação infantil? Ou vice-versa? Nessa perspectiva, relativa aos níveis de ensino e suas especialidades, são grandes os desafios a serem superados.

As coordenadoras Maria Leda e Maria Stella procuraram na vivência da própria coordenação e na interação com alunos e professores elementos que corroborassem o exercício da função, mas nesse processo durante algum tempo a segurança profissional e a identidade como coordenadora ficaram comprometidas:

Então, foi assim, quando eu cheguei, eles já tinham o PEA, era julho e não tinha sido aprovado [...]. Eles (professores e direção) não chegavam a um entendimento com o supervisor que mandava fazer uma coisa e eles não faziam. Primeiro nós fomos organizar o PEA que tinha vários temas, um deles era a avaliação no ensino fundamental [...] nós começamos a discutir sobre avaliação porque estava no PEA, era algo que eu me sentia um pouco mais segura, não tão peculiar, mas eu entendia o contexto, sabia falar sobre isso. (COORD. MARIA LEDA) 
Quando eu entrei na coordenação, vim muito com aquele gás e aquele pique da diretoria de ensino. Pensei: vou colocar as questões da formação em prática. Mas eu vi que são realidades diferentes a escola e a coordenadoria de ensino. São outras dinâmicas. (COORD. MARIA STELLA)

Ainda que o coordenador precise desenvolver uma postura investigativa sobre seu próprio trabalho, o bom acolhimento desse profissional pode fazer diferença, pois chegar num lugar e buscar de forma isolada compreender a cultura da unidade escolar é um processo que pode levar muito tempo e, ainda, incorrer em erros de interpretação e análise.

A forma de acolhimento dos coordenadores assume, nesta perspectiva, um papel importante, pois introduz o profissional na realidade educativa facilitando-lhe o acesso às informações, ao material e às pessoas e revela a disposição da equipe com o trabalho educativo. Os relatos a seguir evidenciam duas formas distintas de acolhimento:

Então vim aqui, nunca tinha nem passado próximo, já tinha ouvido falar, mas não sabia onde ficava, cheguei aqui e quando olhei a escola por fora gostei do visual, das plantas. Em 2000, ela tinha passado por uma pequena reforma, o teatro era novo. Então, entrei, expliquei o problema [que estava visitando a escola porque iria escolher uma unidade para atuar como coordenadora] e me conduziram à assistente, que reconheci como uma amiga de infância, freqüentávamos a mesma igreja. Quando cheguei, ela estava atendendo uma criança, mas era uma conversa tão amena que gostei daquela relação. Então eu a cumprimentei e ela teve o cuidado de me mostrar a escola. Chegando à sala dos professores, me apresentou e disse que talvez eu viesse a ser a coordenadora. Eu senti um acolhimento e na hora decidi - é aqui e pronto. Senti-me pertencendo à escola antes mesmo de escolher. (COORD. MARIA VITÓRIA)

Quando eu estava na escola de ensino fundamental [...] tinha um diretor que muitas vezes me ajudava a organizar o trabalho, a dar andamento às atividades [...]. (COORD. MARIA LEDA)

Quando eu ingressei, foi no mês de janeiro [...]. Eu estava chegando na escola e só tinha alguns profissionais da secretaria. Comecei a fuçar e descobri um pacote com a avaliação da Unidade Escolar, cujas questões eram muito pobres, quase para recolher elogios. (COORD. MARIA AUGUSTA)

A coordenadora Maria Vitória viveu uma experiência muito importante de acolhimento e de contato com a cultura da escola, que criou uma ligação rápida e favoreceu sua inserção no espaço escolar. Situação que, com certeza, amenizou o choque com a realidade de uma escola grande e com as muitas atribuições do coordenador pedagógico.

A coordenadora Maria Leda também vivenciou uma situação muito positiva. Embora não tivesse experiência com a modalidade de ensino, recebeu todo apoio da direção, que 
'ajudava a organizar o trabalho', o que se refletiu na acolhida dos professores e demais funcionários. Embora a insegurança fosse um fato, não se sentia sozinha.

Situação inversa foi experienciada pela coordenadora Maria Augusta, que chegou à escola num período em que a direção não se encontrava presente, então teve que buscar a compreensão do espaço e de sua atividade sozinha, teve de 'fuçar', como ela mesma afirma, para descobrir como a escola funcionava, porque não havia ninguém que a introduzisse naquele meio. $\mathrm{O}$ registro da avaliação não lhe trouxe informações significativas que possibilitassem compreender o modo de organização daquela instituição, o que pensavam os professores sobre os projetos desenvolvidos, os pontos positivos e os que precisavam ser melhorados, as dificuldades enfrentadas e a concepção pedagógica que movia a ação dos educadores.

Em outro momento, essa coordenadora explicita que no primeiro ano foi tão difícil estabelecer parcerias que a fez pensar em desistir. Mas, a mudança da direção permitiu-lhe estabelecer novas relações que possibilitaram a construção de projetos diversos envolvendo a comunidade interna e externa, a ampliação do modelo de formação desenvolvido até então, a vivência de uma gestão participativa que trouxe para dentro da escola a comunidade e a melhoria da aprendizagem dos alunos. No segundo ano, a coordenadora foi acolhida como pessoa e profissional experiente, o que lhe abriu as portas para envolver a equipe docente com a investigação da realidade escola e do próprio trabalho pedagógico desenvolvido.

Os relatos das coordenadoras não revelam coincidências entre as experiências de acolhimento no início da atividade de coordenação pedagógica, mas mostram claramente que o apoio recebido pode contribuir para uma visão favorável desse trabalho, bem como promover a organização do coordenador.

Alguns coordenadores chegam tateando, buscando atuar em situações das quais possuem pouco conhecimento, enquanto procuram entender o contexto e as atribuições da função naquele espaço. Outros iniciam repletos de idéias e dispostos a inovar, 'cheios de gás', mas vão perdendo o entusiasmo frente a uma realidade limitante, numa dinâmica que deixa pouco espaço para a introdução de referências novas. Ser apresentado à complexidade do espaço escolar por um profissional experiente (um tutor) ou por uma direção preocupada com o acolhimento pode significar a diferença entre o comprometimento com o trabalho e os projetos da unidade e a indiferença em relação a eles.

As demandas de trabalho da coordenação pedagógica, pelo seu volume e extensão, indicam aos iniciantes a importância da organização das ações e do planejamento, pois mesmo que a prioridade na escola seja a formação isso não descarta todas as outras 
atribuições, uma vez que a articulação do trabalho pedagógico na escola assume diversas facetas.

\section{3.. O processo de aprender normas, valores e condutas - a cultura da escola}

Os primeiros anos do coordenador pedagógico são marcados, também, pelo mergulho na cultura da escola. Afinal, atuar num determinado espaço/tempo significa conhecer a sua rotina, seus educadores, sua relação com a comunidade educativa e com os órgãos centrais, conhecer os limites e possibilidades da função na relação com as condições materiais e humanas.

Esse é um processo de aprendizagem contínuo que implica conhecer a escola, o seu funcionamento, e o sistema de ensino, com suas leis, normas e regulamentos. A atuação pedagógica não se faz no vazio, ela é concreta e depende de condições objetivas para que sejam atingidas suas metas. Portanto, compreender os modos de organização da cultura escolar em um determinado sistema de ensino é um marco para o desenvolvimento do trabalho educativo. A equipe, quando envolvida por um projeto único, poderá compartilhar suas inseguranças e criar condições para a busca de alternativas frente às situações desafiadoras. Isso só será possível se a opção for pela construção de uma ação cooperativa e coletiva em relação às atividades pedagógicas.

A partir desses elementos iniciais é possível ao coordenador ir construindo uma competência técnica e reflexiva que lhe permita fazer julgamentos e escolhas mais eficientes, confiante nas experiências recém-adquiridas. Observa-se que essa foi a situação narrada pelas coordenadoras:

No primeiro ano em que nós estávamos aprendendo, não que hoje nós saibamos tudo, eu estava mais insegura, tinha aquela preocupação com o que ia trazer, porque os professores pouco contribuíam [...] e tinha um supervisor que era muito burocrático, exigiu um cronograma no PEA. No primeiro momento, quando falamos com os professores sobre o cronograma, eles reclamaram muito, mas no final foi muito bom, porque acabou organizando o trabalho e, por ter sido no coletivo, eles construíram juntos. (COORD. MARIA VITÓRIA)

Não atendo ninguém no horário coletivo [...] eu tenho um cronograma geral de trabalho colado na porta e nele coloco em vermelho os horários que eu estou em JEI. Todos sabem que naquele horário eu estou com os professores e, portanto, não atendo telefone e nem mães de alunos. Peço para passar para ela o melhor horário, lá está discriminado os melhores horários para atender a comunidade. No começo, fica-se naquela ansiedade, meio perdido, mas, 
depois, você vai limpando e vai conseguindo se organizar. (COORD. MARIA STELLA)

O período da iniciação profissional torna-se difícil porque, normalmente, se desconhece a dinâmica do espaço, como opera em relação aos educadores, às idéias que orientam o trabalho, às vezes, até ao conjunto da legislação educativa de um determinado estado ou município que de forma direta ou indireta influi na organização do trabalho pedagógico na escola.

Também é necessário destacar que faz parte do desenvolvimento profissional a busca pela identificação com o outro, a aprendizagem e a mudança de perspectiva. No entanto, considerando o desafio da construção de uma escola pública de qualidade para todos e o deslocamento da formação contínua do docente para a escola, faz-se necessário um investimento cada vez maior na formação inicial e contínua dos profissionais que desenvolvem o trabalho educativo escolar, a fim de que se criem condições para o desenvolvimento de uma racionalidade reflexiva e crítica, que leve à ponderação sobre a prática dos educadores e sobre os conhecimentos pedagógicos elaborados.

Nesta perspectiva, o coordenador assume um papel de destaque, mediado pelas suas experiências profissionais e por uma formação que favoreça a construção de uma saber-fazer na coordenação pedagógica, na organização de um trabalho pautado na reflexão crítica e no protagonismo da equipe escolar na elaboração de um projeto pedagógico local, que estabeleça as bases para o desenvolvimento de crianças, jovens, adultos e educadores por meio de uma educação qualificada e não apenas na implementação de programas externos à escola.

A vivência na função, a relação entre os educadores, os cursos, a vontade de fazer melhor o trabalho, a dedicação, a experimentação, os medos e anseios, o conhecimento das leis, a interação com a comunidade escolar, a humildade para ouvir o outro, sejam os professores, os pais, a supervisão, o diretor ou os alunos, contribuem para a formação do coordenador, que, paulatinamente, vai desenvolvendo sua formação, que é contínua, assim como é permanente e múltiplo o desafio desse profissional, especialmente frente à responsabilidade da formação do docente na escola.

A reflexão sobre esses aspectos ajuda a compreender melhor os limites e possibilidades da ação do coordenador pedagógico na formação contínua do docente pela sua circunscrição a uma história ontogênica e filogênica, o que significa considerar a pessoa do coordenador pedagógico, a criação desse cargo/dessa função imbricado/a com a história da educação paulistana, com a formação inicial e contínua desse profissional. 
A partir dessa compreensão sobre a trajetória da coordenação pedagógica, o próximo capítulo pretende estabelecer uma relação entre a organização-escola e a formação contínua do docente, tomando como parâmetro a relativa autonomia da escola na elaboração de seu projeto político pedagógico e o trabalho na formação como um projeto compartilhado. 


\title{
A ORGANIZAÇÃO-ESCOLA E A FORMAÇÃO CONTÍNUA DO DOCENTE
}

\begin{abstract}
O projecto educativo de escola constitui o instrumento essencial de uma gestão estratégica do estabelecimento de ensino, cuja construção e avaliação, nas suas diferentes facetas, se configura como eixo fundamental de um processo de formação contínua dos professores. É portanto num quadro mais global, balizado pelo projecto educativo de escola, que deve ser pensado e concretizado o plano de formação.
\end{abstract}

Rui Canário

O projeto educativo da escola, conforme salienta o autor em epígrafe, tem um papel essencial na organização da instituição escolar e constitui-se no eixo do processo formativo centrado na escola. Essa compreensão deve considerar a complexidade do espaço escolar que é público e historicamente situado, cujas ações são conduzidas por seus profissionais, dentre eles o coordenador pedagógico. Assim, a formação contínua ganha diferentes sentidos e significados em função das diversas relações que o projeto educativo estabelece.

O objetivo, nesse ponto, é analisar e problematizar o papel do projeto político pedagógico da escola, do diretor e do supervisor no trabalho do coordenador pedagógico na formação contínua do docente. Essa análise visa determinar as contribuições e a influência de cada segmento na articulação dos projetos de formação. Para tanto, toma como referência os depoimentos dos coordenadores envolvidos na pesquisa e a produção acadêmica sobre o tema. 


\section{A formação contínua centrada na escola}

Nóvoa (2001) menciona cinco fases formadoras dos professores, quais sejam: a experiência do docente como aluno na educação de base; sua formação inicial; o estágio supervisionado; os primeiros anos na profissão e a formação continuada. Algumas dessas fases destacadas pelo autor acontecem em simultaneidade: na formação inicial, o futuro docente vive o papel de aluno e de estagiário e a formação contínua pode iniciar-se já nos primeiros anos de docência, na perspectiva de formação em serviço.

Atualmente, no Brasil, assume especial relevância a discussão sobre a formação do docente em serviço. Isso ocorre em virtude de pressões externas, especialmente do Banco Mundial, que advoga um investimento maior dos recursos aplicados em formação docente, na formação contínua, aligeirando a formação inicial ${ }^{51}$.

São profícuos os estudos que apontam a escola como locus de formação docente, principalmente pela proximidade com a prática educativa, favorecendo a reflexão sobre a ação. Autores como Nóvoa (1999, 2001); Canário (1997, 2006); Fusari (1997, 2007); Alarcão (2001); Libâneo (2003) e outros têm corroborado essa idéia. Canário (1997, p.1), refletindo sobre essa temática, faz a seguinte afirmação:

\footnotetext{
A escola é habitualmente pensada como o sítio onde os alunos aprendem e os professores ensinam. Trata-se, contudo, de uma idéia simplista, não apenas os professores aprendem, como aprendem, aliás, aquilo que é verdadeiramente essencial: aprendem a sua profissão. (grifos do autor)
}

Para o autor, a escola apresenta as melhores condições para a formação contínua do docente, pois é lá o lugar em que o professor organiza e exercita sua prática, num contexto dinâmico que possibilita o exercício de uma reflexão orientada pela própria prática pedagógica.

\footnotetext{
$51 \quad$ Sobre o Banco Mundial e as políticas públicas, ver TOMASI, L de, WARDE, M. J., HADAD, S. (org.)
} O Banco Mundial e as políticas educacionais. São Paulo, Cortez, 2000. 
A formação contínua na escola não assume caráter compensatório e nem diminui a importância e a necessidade da formação inicial, concentradas nos cursos de Pedagogia e de licenciatura. Esses cursos devem caracterizar-se por sua excelência e não apenas como academização da formação de professores, evidenciada por um processo de progressiva subordinação da formação profissional à lógica tradicional da universidade clássica, baseada na valorização de conhecimentos desvinculados das demandas da realidade cotidiana da educação verificadas nas diversas escolas espalhadas pelo nosso grande território nacional.

A ênfase na profissionalização continuada, na prática reflexiva e nas dimensões sociais e políticas do trabalho pedagógico na escola faz oposição a uma concepção que, protegida pelo discurso da qualidade e pela pseudoneutralidade das avaliações institucionais, tendem a atribuir ao professor a responsabilidade pela baixa qualidade da educação, pelo fracasso educacional.

Não obstante, a produção na área da formação docente no Brasil e no exterior tem atribuído à escola e às socializações profissionais desenvolvidas nesse espaço uma especial importância como elemento de formação contínua do docente, principalmente quando enfoca a escola como contexto de ação e reflexão do professor, ressignificando-a, tornando-a um lugar onde os professores aprendem a profissão pela relação entre teoria (pesquisas, estudos, discussões e trocas de experiências) e a prática (sala de aula).

Corrobora também, para essa reflexão, o debate atual que valoriza as experiências profissionais docentes como reveladoras de uma epistemologia construída a partir da prática, num processo de reflexão sobre o fazer. Nóvoa (1992); Schön (1992); Marcelo Garcia (1999); Sacristán (1995); Contreras (2002); Pimenta (1996; 1998; 2002a), entre outros, vêm enfatizando que o professor é um profissional que reflete sobre o seu saber e o seu saberfazer, contextualizado num processo de profissionalização contínua que reorienta suas concepções e a sua prática.

Ao se abordar o tema da formação contínua do docente na escola, vale a pena destacar que, formalmente, a expressão 'formação contínua' é atribuída às experiências formativas vivenciadas após o período da formação inicial. Essa discussão tem despertado o interesse de profissionais de educação e de pesquisadores interessados em refletir sobre o desenvolvimento profissional docente e sobre a relação dessa temática com o sucesso ou o fracasso dos alunos na escola pública. Fusari \& Franco (2005, p. 21) reafirmam a existência desse entendimento: 
[...] via de regra, a formação contínua vem sendo compreendida como aquela que ocorre após a formação inicial (magistério em nível superior, licenciatura, bacharelado), a partir do ingresso do sujeito na carreira do magistério. Dito de outra forma, tudo aquilo que ocorreu antes do ingresso no trabalho entra na categoria da formação inicial e o que ocorre depois, na categoria de formação contínua. Seria como se tivéssemos dois tempos distintos no processo de formação: um tempo anterior e outro posterior.

Neste estudo, a expressão formação contínua será tomada na mesma perspectiva, entendida como um continuum formativo que tem sua origem na formação inicial, compreendendo um processo que acompanha toda a vida do educador. A formação contínua centrada na escola constitui-se numa das modalidades de formação contínua que visa, nesse continuum, o desenvolvimento profissional, teórico e prático do educador no próprio contexto de trabalho.

No entender de Libâneo (2003), acompanhar a formação contínua, dentro da jornada de trabalho, é uma tarefa que envolve o setor pedagógico da escola, ou seja, o coordenador pedagógico. Nas palavras do autor:

[...] é na escola, no contexto de trabalho, que os professores enfrentam e resolvem problemas, elaboram e modificam procedimentos, criam e recriam estratégias de trabalho e, com isso, vão promovendo mudanças pessoais e profissionais" (LIBÂNEO, 2003, p.189).

Assim, a escola torna-se um lugar profícuo para a formação porque congrega a atividade profissional, a possibilidade de reflexão sobre a ação, bem como um profissional específico para promovê-la.

A formação contínua, para promover mudanças, pressupõe ações que considerem as necessidades dos professores iniciantes e veteranos, ou seja, a participação de todos os profissionais nas discussões e decisões pedagógicas; a elaboração e a avaliação do projeto político pedagógico; a organização de projeto de estudo e das reuniões para a discussão da prática pedagógica. Portanto, torna-se parte das condições de trabalho profissional dos docentes e envolve os sistemas de ensino e as escolas, assegurando as condições institucionais, técnicas e materiais para o desenvolvimento profissional permanente do professor.

Marcelo Garcia (1999, p.171), ao considerar aspectos referentes à formação na escola, ressalta que tal concepção tem como princípio "[...] entender a escola como lugar onde surgem e se pode resolver a maior parte dos problemas de ensino". Tal análise pressupõe o envolvimento dos educadores não só no processo de detectar os problemas, mas sobretudo na 
proposição de soluções locais. Pimenta (2002a, pp 72-73) confirma essas ideias, quando faz a seguinte reflexão: "Trabalho coletivo significa tomar a problemática da escola coletivamente com base na individualidade de cada um, da colaboração específica de cada um, em direção a objetivos comuns [...]”. A autora destaca a implicação pessoal como um fator decisivo nas ações coletivas, o que inclui a formulação da própria formação contínua, que, por caracterizar-se como processo compartilhado, pode significar adesões e resistências de alguns da equipe.

Os projetos de formação desenvolvidos fora da escola (cursos, seminários, palestras...) por sua natureza generalista, que também têm seu valor e importância, não tocam em aspectos específicos que a formação na escola pode garantir, mas isso, se, de fato, houver a colaboração de todos os envolvidos para atingir os objetivos formulados coletivamente.

Na história da Rede Municipal de Ensino, a formação oferecida pelo sistema, por meio das políticas públicas, configurou-se como 'reformas educativas' mobilizadas por mudança de gestão administrativa. Tais reformas, por vezes, ao investirem na formação contínua do professor, focam os olhares na figura do coordenador pedagógico como o elemento intermediador entre as políticas de formação e o profissional na escola. Assim, os gestores públicos passaram a investir na formação instrucional desse profissional de modo a refinar sua competência na divulgação dos projetos de governo.

Marcelo Garcia (1999) aponta que o êxito no processo de formação centrado na escola diz respeito às condições para essa iniciativa, ou seja, a necessidade de liderança (diretores, professores); o clima relacional entre os membros da escola, influenciado pela cultura grupal e pela cultura do meio; os próprios professores e seu comprometimento com um projeto voltado à melhoria da escola; e à natureza da formação proposta, se, reflexiva, dinâmica e sensível ao contexto. Todos esses aspectos contribuem para o bom desenvolvimento dessa modalidade de formação.

Ao enumerar essas condições, o autor reafirma a importância do coordenador pedagógico na liderança do processo formativo desenvolvido na escola, embora não tenha usado esse termo especificamente. A ideia de um 'líder' ou coordenador que promova o processo reflexivo está explícita, bem como a relação do grupo e o compromisso individual. Em concordância com o autor, é possível afirmar que o coordenador coordena um grupo de pessoas, homens e mulheres que se dispuseram a pensar coletivamente sobre o seu fazer e o espaço social em que esse fazer se desenrola.

Libâneo (2003) acrescenta que cabe ao coordenador a difícil tarefa de auxiliar o professor no desenvolvimento do trabalho pedagógico de modo a contribuir com a melhoria 
da qualidade do ensino, construindo e administrando situações de aprendizagem adequadas às necessidades educacionais dos alunos, por meio da reflexão e da investigação. Esse procedimento está associado a um processo de formação contínua e sistemática que considera as necessidades dos educadores envolvidos.

Subsidiar a reflexão dos professores em serviço, problematizando as razões que justificam suas opções pedagógicas e suas dificuldades, pode favorecer a tomada de consciência dos professores sobre suas ações e estimular a pesquisa em torno dos conhecimentos que levem a superar essas situações. Assim, a formação contínua centrada na escola possibilita a mudança educativa pelo envolvimento do professor no processo de desenvolvimento profissional. Candau (1997, p. 57) reafirma a importância da escola como locus de formação:

[...] considerar a escola como locus de formação continuada passa a ser uma afirmação fundamental na busca de superar o modelo clássico de formação continuada e construir uma nova perspectiva na área de formação continuada de professores. Mas este objetivo não se alcança de maneira espontânea, não é o simples fato de estar na escola e de desenvolver uma prática escolar concreta que garante a presença de condições mobilizadoras de um processo formativo. Uma prática repetitiva, uma prática mecânica não favorece esse processo. Para que ele se dê, é importante que essa prática seja uma prática reflexiva, uma prática capaz de identificar os problemas, de resolvê-los, e cada vez mais as pesquisas são confluentes, que seja uma prática coletiva, uma prática construída conjuntamente por grupos de professores ou por todo o corpo docente de uma determinada instituição escolar.

Garrido (2007), Fusari (1997; 2007), Christov (2001, 2005), Libâneo (2003) têm apontado a coordenação da formação contínua em serviço como um dos aspectos fundamentais do trabalho do coordenador pedagógico. Registram também a natureza complexa desse tipo de intervenção no espaço escolar em que as concepções de educação são diversas. Nesse sentido, o trabalho ganha significado se tem seu foco na compreensão da realidade escolar e seus desafios, ao se somarem esforços na construção de um sentido coletivo das ações pedagógicas em que sejam consideradas alternativas que se mostrem adequadas aos desafios enfrentados pelos professores.

Esses autores também apontam o perigo de a formação na escola ficar restrita a esse território e, apenas, sob o olhar do coordenador pedagógico, não por uma restrição espacial ou incapacidade do formador, mas, principalmente, pela possibilidade benéfica e relevante dos educadores (professores e o próprio coordenador) terem suas 'verdades' problematizadas em outros espaços. 
Na última década, principalmente, observou-se que o discurso da escola como locus de formação docente rompeu as esferas acadêmicas e tem sido incorporado pelas políticas públicas que, via de regra, apostam nesse 'modelo' de formação, como aquele capaz de promover as políticas educacionais que identificam o sistema e o desenvolvimento profissional docente, além de oportunizar a economia de gastos com a formação contínua do docente por meio de cursos fora da escola.

Nesta perspectiva, alguns estados e municípios têm se organizado para criar as condições para que as escolas desenvolvam a formação. O estado de São Paulo consolidou essa idéia com a conquista do Horário de Trabalho Pedagógico (HTP), no final da década de 1980, e da figura do professor-coordenador que foi criado na mesma época ${ }^{52}$. O município de São Paulo criou o cargo de coordenador pedagógico em 1985 e estabeleceu a Jornada de Tempo Integral (JEI) em $1992^{53}$.

As políticas educacionais paulistas ilustram bem a idéia de que a formação contínua na escola exige tempo para o desenvolvimento de um 'programa de formação' e a presença de um profissional que a articule. Normalmente, no caso de São Paulo, essa pessoa tem sido o coordenador pedagógico, mas também poderia ser um diretor ou um professor que assuma a função de coordenador.

Os teóricos Canário (1997); Nóvoa (1992, 2002) e Marcelo Garcia (1999), ao enfatizarem a escola como locus de formação, buscam superar a dicotomia entre teoria e prática que durante muito tempo separou - e ainda separa - os pesquisadores daqueles que exercem a docência. Para Fusari (1997, p.167), em uma formação assim organizada, “[...] a escola teria, a partir do diagnóstico de suas necessidades, vários e diferentes projetos em andamento [...]”, que, por estarem localizados na escola, considerariam o percurso biográfico de seus profissionais, o exercício do trabalho e a necessidade de reflexão sobre a ação profissional como fatores decisivos ao processo de produção da profissionalidade docente.

Nesta perspectiva, a produção (e a mudança) das práticas profissionais remete, fundamentalmente, para o processo de socialização profissional, vivido nos contextos de trabalho, onde coincidem, no espaço e no tempo, uma dinâmica formativa e um processo de construção identitária. (CANÁRIO, 1997, p.2)

\footnotetext{
52 Vale ressaltar que anterior a esse momento, as escolas estaduais contaram com a presença do coordenador pedagógico, porém, não havia a conjunção entre a função e a jornada dos professores. Também, a presença desse profissional, nesse primeiro momento, não estava associada à formação do professor, salvo raras exceções como as desenvolvidas no antigo Colégio Experimental da Lapa, conforme relato de Salvador (2000).

53 No Capítulo II deste trabalho, esta situação é tratada de forma detalhada.
} 
Para Canário (1997), aspectos como a troca de experiência ou, como por ele denominado, a 'socialização profissional', passíveis de serem desenvolvidos nos espaços coletivos da escola, fazem coincidir, nesse espaço/tempo de formação contínua, a prática docente e a reflexão sobre a prática, tornando-o especialíssimo para o desenvolvimento profissional docente.

Os professores que participaram da pesquisa enfatizaram a importância da troca de experiências como fator principal no processo formativo desenvolvido na escola. Esse discurso foi recorrente, tanto durante as atividades do grupo dialogal quanto durante o acompanhamento do trabalho dos coordenadores. Os professores falavam sobre isso e trocavam experiências, nas situações organizadas pela coordenadora e fora delas. Além disso, os coordenadores entrevistados apontaram a importância da troca de experiência entre seus pares e na própria escola como um dos elementos do processo formativo.

Esse aspecto da formação orienta, necessariamente, essa reflexão para a singularidade dos espaços escolares. Nenhuma escola é igual à outra, assim como é única cada turma na escola. Por isso, as trocas de experiências tornam-se tão singulares e particulares como cada espaço educativo.

A formação desenvolvida no espaço escolar pressupõe a ideia de que os professores são capazes de decidir coletivamente sobre o que querem aprender para alcançar os conhecimentos e as competências que consideram necessárias para o seu desenvolvimento profissional. Marcelo Garcia (1999, p.150) salienta que tal postura é:

[...] coerente com os princípios de formação de adultos, na medida em que os adultos aprendem de forma mais adequada quando são eles que indicam e planejam as atividades de desenvolvimento profissional.

Fusari (1997) acrescenta que o desenvolvimento profissional docente pressupõe condições subjetivas e objetivas de trabalho:

\begin{abstract}
A formação contínua na escola e fora dela dependem, como dissemos, das condições de trabalho oferecidas aos educadores, mas depende também das atitudes destes diante de seu desenvolvimento profissional [...]. Cada educador é responsável por seu processo de desenvolvimento profissional; cabe a ele o direcionamento, o discernimento e a decisão de que caminhos percorrer. (FUSARI, 1997, p.171)
\end{abstract}

Situação semelhante a essa foi observada na pesquisa. Uma das escolas estava em reforma e o espaço para a formação, sala de JEIF, era muito pequeno, quase não comportava os professores daquele grupo e limitava o uso de recursos tecnológicos. Na outra escola, a 
sala dos professores tinha um duplo uso, acolher os professores para a formação e receber os que estavam em horário de intervalo. Em ambas as escolas, apesar da falta de condições físicas adequadas, havia por parte da equipe uma disposição para que isso não fosse um impedimento da formação.

Nesse sentido, a formação do docente na escola, longe de ser apenas um deslocamento do espaço formativo, é, antes de tudo, uma possibilidade de ação com vistas a uma nova concepção de formação contínua do docente, produto de uma constituição histórica, da complexa dinâmica da escola objetivada, das relações estabelecidas pelos sujeitos envolvidos nesse processo e das condições oferecidas.

Nóvoa (2002) destaca a imprevisibilidade do que acontece na escola como um dos aspectos a serem considerados na formulação de processos de desenvolvimento profissional centrado nesse espaço. Ademais, entende que o professor precisa rejeitar a posição de técnico e assumir-se como profissional crítico-reflexivo e isso só é possível com a ruptura do individualismo e a construção do coletivo escolar.

A formação contínua deve contribuir para mudança educacional e para a redefinição da profissão docente. Neste sentido, o espaço pertinente da formação contínua já não é o professor isolado, mas sim o professor inserido num corpo profissional e numa organização escolar. (NÓVOA, 2002, p. 38)

A organização da escola para dar conta da formação pressupõe professores envolvidos com um processo de 'autoformação', que se configura nas trocas de experiências qualificadas, ou seja, na socialização crítica, com outros profissionais, das experiências docentes, mediada pelo coordenador pedagógico, assumindo, como diz Nóvoa (2002, p.39), o papel ora de formador, quando relata, ora de formando, quando na condição de ouvinte. Para o autor, a partilha dos conhecimentos profissionais é o "[...] processo que pode conduzir a uma produção pelos próprios professores de saberes reflexivos e pertinentes”. Canário (1995, p.12) explica esse processo da seguinte maneira:

A optimização do potencial formativo dos contextos de trabalho passa, em termos de formação, pela criação de dispositivos de dinâmicas formativas que facilitem a transformação das experiências vividas no quotidiano profissional, em aprendizagens a partir de um processo autoformativo, marcado pela reflexão e a pesquisa a nível individual e coletivo.

Nesta perspectiva, o processo formativo do docente no espaço escolar não pode ser concebido, pelas políticas públicas, como um treino, em que os momentos coletivos se 
transformem numa condição para 'transmitir conhecimentos' ou 'treinar' o profissional que deverá reproduzir as experiências 'apreendidas' no exercício da docência. Este modelo de formação não leva em conta as demandas reais da instituição de ensino, pois atua sempre de forma genérica. Para Nóvoa (2002, p. 40):

A formação contínua alicerçada na dinamização de projectos de
investigação-acção nas escolas, passa pela consolidação das redes de
trabalho colectivo e de partilha entre os diversos actores educativos,
investindo as escolas como lugares de formação.

A formação contínua na escola deve estar orientada por um paradigma apoiado no trabalho coletivo, na investigação da ação pedagógica realizada e na cooperação em prol do desenvolvimento profissional docente e da melhoria da educação oferecida aos discentes. Esses moldes implicam a organização de uma estrutura que pode ser caracterizada, de maneira mínima, por quatro aspectos:

6. A organização do tempo/espaço na escola para desenvolver esse processo de formação;

7. A aproximação com as necessidades formativas da escola;

8. A corresponsabilidade dos professores pelo seu desenvolvimento profissional;

9. O investimento num profissional (coordenador pedagógico) habilitado para promover a reflexão para além de uma socialização profissional que se caracterize pela mera troca de 'receitas de atividades'.

Libâneo (2003), referindo-se à escola como lugar de aprendizagem para o professor, alerta para o perigo do discurso da formação centrada na escola vir a ser uma desobrigação do Estado em relação a esse aspecto, aumentando a demanda de trabalho da escola sem a devida adequação de recursos humanos, financeiros e materiais. Contudo, tal iniciativa pode, também, constituir-se em uma ação de valorização dos profissionais que passam a decidir coletivamente sobre o seu trabalho. O autor faz referência ao trabalho do coordenador pedagógico como articulador das decisões coletivas em prol da formação:

O pedagogo escolar [referindo-se ao coordenador pedagógico] deverá ser o agente articulador das ações pedagógico-didáticas e curriculares, assegurando que a organização escolar vá se tornando um ambiente de aprendizagem, um espaço de formação contínua onde os professores refletem, pensam, analisam, criam novas práticas, como sujeitos pensantes e não como meros executores de decisões burocráticas. (LIBÂNEO 2003, p. 29) 
Aos dados da pesquisa somam-se as falas dos autores que referendam a ideia da escola e da formação vistas de maneira conjugada. A coordenadora Maria Vitória, quando questionada sobre a contribuição do seu trabalho para a organização do coletivo escolar, faz a seguinte análise:

Eu acho que a maior contribuição é a organização dos processos de formação. [...] Se o coordenador não cuidar disso, ninguém mais vai cuidar. Isto é o prioritário, porque está junto do pedagógico. Se o professor não tem formação, o processo pedagógico fica estagnado, pois ele tem que estar sempre discutindo e aprendendo, não só por meio das práticas, mas também pelo conhecimento teórico.

As considerações das coordenadoras entrevistadas somam-se ao depoimento da coordenadora Maria Vitória e revelam uma ênfase no modelo formativo centrado no espaço escolar, cuja articulação foi descrita como a atribuição principal do trabalho da coordenação pedagógica, ou seja, dar apoio, sustento organizacional e pedagógico aos professores, de modo a favorecer o desenvolvimento profissional docente e, consequentemente, a melhoria da aprendizagem dos alunos.

\section{O projeto político pedagógico como expressão da relativa autonomia, vontade e necessidade formativa das equipes escolares}

A proposta de formação do docente na escola não é uma ação descolada de uma estrutura organizativa, de um compromisso com os alunos e com a comunidade, de intenções formativas e do trabalho coletivo. Ou seja, tal proposta deve estar inserida no projeto pedagógico da escola, configurando-se como um plano de formação docente que, associado às demandas educativas da escola, promova o desenvolvimento do trabalho pedagógico, o desenvolvimento profissional docente e a construção de uma escola voltada para uma educação de qualidade para todos.

Nessa estrutura, deve haver uma ligação intrínseca entre as demandas escolares e a formação docente, que tende a caracterizar-se pelo paradoxo marcado pela aproximação da prática docente e do currículo escolar e, ao mesmo tempo, pelo afastamento que possibilita o exercício da reflexão sobre a teoria e a prática, para a re-significação da profissionalidade docente. Segundo Fusari e Franco (2005, p. 24), a formação docente em serviço, expressa no projeto político pedagógico, configura-se por reconhecer: 
[...] os saberes que (os professores) produzem no exercício da profissão docente, suas possíveis contribuições para o desenvolvimento institucional, suas diferentes necessidades formativas, as reais condições de trabalho e os desejos educacionais que ali existem.

A formação contínua centrada na escola possibilita que se tomem elementos da experiência do docente e das necessidades da história da escola local como referência para a reflexão, caracterizada pela diversidade de propostas formativas ancoradas na multiplicidade de escolas existentes. Para Libâneo (2003, p. 29), existe uma relação entre o desenvolvimento profissional do docente e a organização do projeto de escola:

O desenvolvimento profissional e a conquista da identidade profissional dependem de uma união entre pedagogos especialistas e os professores, assumindo juntos a gestão do cotidiano da escola, articulando num todo o projeto pedagógico da escola, o sistema de gestão, o processo de ensino aprendizagem, a avaliação. Fazendo assim ter-se-á uma organização preocupada com a formação continuada, com a discussão conjunta dos problemas da escola, discussão que é de natureza organizacional, mas principalmente pedagógica e didática.

Esta organização defendida por Libâneo (2003) e configurada no projeto político pedagógico das escolas, consolida a cultura da escola identificando-a, organizando-a e legitimando-a, por meio de princípios pedagógicos, éticos e políticos que, bem definidos, tornam-se finalmente em ações educativas (PINTO, 2006).

Uma escola cujo projeto educativo considera a 'educação para todos' como finalidade, estendendo essa expressão para além do acesso e da permanência, precisa pensar no contexto em que a comunidade está inserida e propor formas de promover o acesso e o domínio do conhecimento por ela veiculado.

A cultura que se projeta em todas as instâncias da escola é um condicionante do projeto político pedagógico, pois os elementos da cultura da escola acabam por tomar forma no plano de trabalho da unidade - o PPP - que explicita a concepção que orienta as ações que o viabiliza. Configurando-se, segundo Libâneo (2003, p.85),

[...] no tipo de reuniões, nas normas disciplinares, na relação dos professores com os alunos na aula, na cantina, nos corredores, na confecção dos alimentos e distribuição da merenda, nas formas de tratamento com os pais, na metodologia de aula etc. Vem daí uma constatação muito importante: a escola tem uma cultura própria que permite entender tudo o que acontece nela, mas essa cultura pode ser modificada pelas próprias pessoas, ela pode ser discutida, avaliada, planejada, num rumo que responda aos propósitos da direção, da coordenação pedagógica, do corpo 
docente. É isto que justifica a formulação conjunta do projeto pedagógicocurricular [...]. A cultura organizacional é elemento condicionante do projeto pedagógico-curricular, mas este também é instituidor de uma cultura organizacional. (grifo do autor)

Assim, o projeto político pedagógico considera em sua estrutura aspectos locais e específicos, sem abandonar as configurações mais globais (dos conhecimentos construídos, de experiências externas, da situação social e política que move a sociedade) que também condicionam a realidade local.

O quadro que segue, organizado a partir dos depoimentos das coordenadoras, indica os aspectos evidenciados à menção do projeto político pedagógico da escola. Foram identificadas quatro categorias que são ilustradas com alguns trechos das declarações dessas profissionais.

\section{O projeto político pedagógico como referência para a formação centrada na escola}

\begin{tabular}{|c|l|}
\hline \multirow{2}{*}{$\begin{array}{c}\text { A CULTURA } \\
\text { LOCALAR }\end{array}$} & $\begin{array}{l}\text { "O interessante é que eu conhecia a escola pela fama do diretor, mas os projetos eu } \\
\text { só vim a conhecer aqui. Eu não conhecia muito esse discurso de que aqui era uma } \\
\text { escola de projetos, fiquei sabendo logo que entrei. Na prática, era mais discurso, o } \\
\text { chavão da escola de projetos". (COORD. MARIA VITÓRIA) } \\
\text { "A cultura da escola também passa pela experiência das pessoas, o jeito de cada } \\
\text { escola. Quando a gente fala de cultura escolar, não dá para generalizar". (COORD } \\
\text { MARIA VITÓRIA) } \\
\text { "Uma questão forte é a das relações, que em alguns momentos estão mais } \\
\text { estabelecidas. Todos sabem que é uma escola em que as dificuldades serão } \\
\text { discutidas coletivamente, que as pessoas serão tratadas abertamente, sem imposição, } \\
\text { mas com negociação [...]. A forma como as coisas acontecem caracteriza bem a } \\
\text { escola, nós estamos sempre envolvendo os pais. No conselho de escola, o presidente } \\
\text { é um pai [...] o que caracteriza mesmo a escola é a participação da comunidade, as } \\
\text { relações democráticas e os projetos". (COORD. MARIA STELLA) } \\
\text { "Hoje, nas festas, você não vê criança brigando, sujeira, ou alguém avançando na } \\
\text { comida. Você vê pessoas conversando, é muito lindo mesmo". (COORD. MARIA } \\
\text { AUGUSTA) } \\
\text { "No segundo período, tem uma questão que eu considero terrível na escola pública } \\
\text { que é o individualismo, que não considera o todo, e a gente tem que quebrar com } \\
\text { isso". (COORD. MARIA AUGUSTA) }\end{array}$ \\
\hline $\begin{array}{l}\text { "Hoje se fala em formar o cidadão, mas não há aulas que ensinem justiça e } \\
\text { solidariedade. Na prática, isso é difícil de se conseguir na escola. Nós tentamos, há } \\
\text { o projeto pedagógico que enfoca a formação do cidadão, nós queremos formar o } \\
\text { aluno com valores, que seja solidário, justo, que seja leitor. Então, temos que } \\
\text { construir um trabalho em que todos enfoquem isso, para que percebam que nessa } \\
\text { escola se trabalha a formação do cidadão". (COORD. MARIA VITÓRIA) }\end{array}$ \\
\hline
\end{tabular}




\begin{tabular}{|c|c|}
\hline $\begin{array}{l}\text { O CURRÍCULO } \\
\text { ESCOLAR }\end{array}$ & $\begin{array}{l}\text { "Nós tentamos abordar as áreas durante o ano, mas não dá para seguir à risca. Por } \\
\text { exemplo, depois que comecei este ano a formação com o instituto "Avisa-lá', a } \\
\text { ênfase dada no curso era o brincar, e o brincar como reflexão só aconteceria no } \\
\text { nosso projeto no segundo bimestre. E eu não conseguia introduzir esta discussão } \\
\text { porque estávamos estudando artes visuais e este tema levou muito mais tempo do } \\
\text { que eu imaginava [...]. Ainda é uma dificuldade na educação infantil a questão do } \\
\text { brincar e do levar a sério esse brincar". (COORD. MARIA LEDA) } \\
\text { "Nós trabalhamos muitos anos com datas comemorativas, só que quando a } \\
\text { começamos estudar percebemos as necessidades das crianças, nas concepções de } \\
\text { infância essas datas não são importante. [...] Então, nós conversamos e concordamos } \\
\text { que trabalharíamos algumas datas que estão na mídia, que não dá para fugir, como } \\
\text { a páscoa, o dia das mães, o dia dos pais, a festa junina e o natal. Estas opções estão } \\
\text { relacionadas a um trabalho pedagógico". (COORD. MARIA LEDA) } \\
\text { "Como havia três ciclos, fomos desmembrando a questão da cidadania como } \\
\text { temáticas para cada ciclo e foi uma coisa muito legal porque no ciclo I a escolha foi } \\
\text { 'Leitura e escrita como direito', isso foi de uma felicidade incrível, porque quando } \\
\text { começamos a discutir com os professores, eles foram entendendo que a questão do } \\
\text { ensino da leitura e da escrita não é só a decodificação, é uma questão de cidadania } \\
\text { mesmo". (COORD. MARIA AUGUSTA) }\end{array}$ \\
\hline $\begin{array}{c}\text { O USO DO } \\
\text { HORÁRIO } \\
\text { COLETIVO }\end{array}$ & $\begin{array}{l}\text { "[...] na prefeitura nós ainda temos a vantagem do horário coletivo e esse horário } \\
\text { nos permite fazer muita coisa, encaminhar trabalhos, fazer discussões. Tem dia que } \\
\text { você sai da JEI meio frustrada, mas tem dia que você sai com a sensação de } \\
\text { plenitude. Eu acho que o coordenador por ter um trabalho coletivo, junto com } \\
\text { professores, e esse ser um momento em que as pessoas possam colocar-se, } \\
\text { dificilmente se sai do jeito que entrou, principalmente nos dias de coletivo". } \\
\text { (COORD. MARIA VITÓRIA) } \\
\text { "No espaço público, o que nós temos são os horários coletivos e as reuniões } \\
\text { pedagógicas. Aqui na escola o espaço de formação é para discussão, para refletir, } \\
\text { para conversar sobre os problemas e dificuldades. Nos horários coletivos e nas } \\
\text { reuniões pedagógicas, normalmente, escolhemos um tema, em que o grupo tenha } \\
\text { dificuldade, para discutir, para conversar [...]". ( COORD. MARIA LEDA) } \\
\text { "Não dá para engessar o horário coletivo, desse jeito. Os programas de governo } \\
\text { quem coordena é a outra coordenadora que fica no segundo período". (COORD. } \\
\text { MARIA AUGUSTA) }\end{array}$ \\
\hline $\begin{array}{l}\text { AUTONOMIA } \\
\text { DOS PROJETOS }\end{array}$ & $\begin{array}{l}\text { "O nosso objetivo era possibilitar que cada grupo de JEI pensasse sobre o projeto de } \\
\text { formação, o tema seria comum. Isso facilitou. Todo mundo sabia que o problema } \\
\text { era alfabetização". (COORD. MARIA VITÓRIA) } \\
\text { "A autonomia que temos é relativa, porque dependendo do que for proposto, pode } \\
\text { não ser aprovado [...]". (COORD. MARIA STELLA) } \\
\text { "Quando começamos como coordenadoras, era o grupo quem elaborava os projetos } \\
\text { e nós íamos tentando, dentro dos grupos, organizar as informações com os } \\
\text { professores, as expectativas e as necessidades, construindo o projeto junto com eles. } \\
\text { Até o ano passado nós formos seguindo essa linha e aperfeiçoando. Esse ano veio o } \\
\text { programa do ler e escrever [...]". (COORD. MARIA STELLA) }\end{array}$ \\
\hline
\end{tabular}




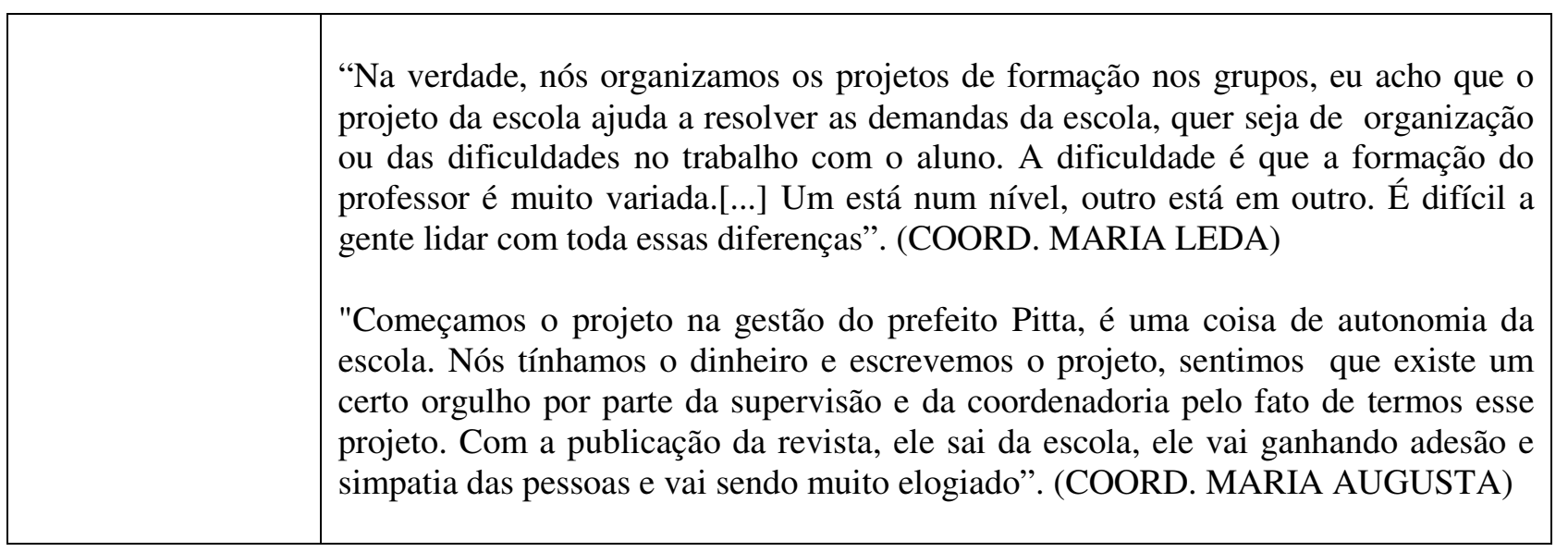

Quadro 07. Elaborado a partir das entrevistas com as coordenadoras

No quadro anterior, as coordenadoras fazem algumas considerações sobre aspectos relativos ao projeto político pedagógico que possibilitam estabelecer relações entre a configuração desse documento e o trabalho do coordenador na formação contínua do docente. E destacaram como a cultura da escola ${ }^{54}$ influi no modo de articular a formação desenvolvida nesse espaço.

Uma escola com fama de democrática ou com projetos inclusivos, quer sejam sociais ou relativos aos alunos com necessidades educativas especiais, vai exigir do coordenador articulações diferentes, a começar por um contrato didático que contemple essas e outras diferenças. No primeiro caso, a proposta de formação precisa envolver os professores num ambiente colaborativo e sem licenciosidade e, no segundo caso, buscar o comprometimento e a organização do trabalho pedagógico considerando os saberes já construídos sobre o tema da inclusão e a pesquisa. $\mathrm{Na}$ verdade, as peculiaridades que caracterizam as diferentes escolas estão relacionadas à história de cada uma delas e das pessoas que por elas passaram, dandolhes uma 'fisionomia' que pode ser agradável ou não. Segundo Santos (2004, p.1151), “Também é importante considerar que mudanças na formação docente têm como limite os próprios interesses e valores que orientam os docentes e que presidem a cultura das escolas".

Mas existem fatores como o individualismo e a falta de compromisso que são, por vezes, identificados como um traço da cultura de determinadas escolas. Nesses casos, o trabalho da equipe e os projetos de formação podem ser elementos que favoreçam uma mudança de postura.

$54 \quad$ Esse aspecto será fundamentado no capítulo IV. 
O currículo de uma escola também influi na formação, pois nem sempre o que os professores professam em nível conceitual é observado na prática. Assim, trabalhar com o currículo desenvolvido, ou o currículo oculto, pode contribuir para desvelar a realidade local.

O projeto de formação dos professores deveria compor o projeto político-pedagógico de cada escola. Nele fica explicitada a organização da escola em relação ao uso que se dá aos horários coletivos, à JEIF.

Os depoimentos das coordenadoras no quadro anterior revelam que, apesar da portaria que regula a organização dos projetos de formação na escola, existe um espaço de autonomia que pode ser desenvolvido por meio de um trabalho consistente, pautado no envolvimento coletivo e na identificação dos problemas a serem resolvidos. Coincidência ou não, as duas escolas de ensino fundamental tinham como metas, antes da última Portaria do PEA, a alfabetização dos alunos e um trabalho com a leitura e a escrita em todos os anos do ensino fundamental. Ocupar os espaços de autonomia, ainda que de maneira 'relativa', significa apostar na concepção de que a escola pode resolver seus problemas, por meio de parcerias entre os envolvidos, cabendo ao sistema dar condições para que as ações se concretizem, avaliando as diversas possibilidades formativas e seus resultados junto aos alunos.

Portanto, falar em autonomia do projeto político pedagógico é considerar a escola como uma instituição pública, gerida por um sistema legal e burocrático. Dessa forma, o espaço de autonomia passa a ser aquele desenvolvido nas brechas legais e pela capacidade de crítica da equipe escolar, em relação aos projetos prontos.

Planejar a ação pedagógica é um passo para consolidar o plano de trabalho da escola que pode adquirir os contornos da cultura da escola. No entanto, ainda assim, se configurará num documento-ação, sujeito a alterações circunstanciais, fruto das decisões democráticas, do aprimoramento dos processos de organização da escola e das determinações legais que retratam as mudanças de concepções, como as apontadas na LDB, Lei nº 9394/96.

Conceber um projeto educativo local é impor um certo grau de autonomia, é revelar singularidades, é desvelar a identidade da escola e seu compromisso pedagógico sem depender da tutela dos órgãos centrais. A atual LDB, Lei $n^{\circ}$ 9394/96, possibilitou pensar de forma 'genérica' em autonomia progressiva da escola, em projeto político pedagógico local e na formação contínua do docente, conceitos estes que foram generalizados em todo território nacional.

A coordenadora Maria Augusta, no trecho abaixo, relaciona o projeto de formação, os PEAs, ao projeto político pedagógico das escolas, estabelecendo uma ligação intrínseca entre eles, de modo que o primeiro vai produzindo ações para concretizar o segundo: 
Neste ano, quando nós escrevemos o texto do projeto político pedagógico tendo como tema a cidadania, nós já pensamos num único PEA, este mais relacionado com a questão da formação do educador, de modo a organizar a discussão e o planejamento, dando concretude ao PPP.

Nóvoa (2002) referindo-se à formação centrada na escola, defende que ela está alicerçada em dois pilares estratégicos, a pessoa-professor e a organização-escola, o que a condiciona a um espaço coletivo, ou seja, “[...] um professor inserido num corpo profissional e numa organização escolar..." (p. 38) que está articulado com o projeto educativo da instituição. Para o autor:

A escolha dos modelos de formação contínua deve ter em conta a valorização das "formações informais", desde os processos de autoformação até o investimento educativo das situações profissionais, e a articulação com os projectos educativos da escola, no quadro de uma autonomia do estabelecimento de ensino. (NÓVOA, 2002, p. 38)

As coordenadoras pedagógicas afirmaram a importância de os projetos de formação estarem imbricados com o projeto político-pedagógico da escola, pois ambos são construções coletivas dos sujeitos que coexistem neste espaço. No quadro anterior, é possível observar nos depoimentos o imbricamento entre o projeto político da escola e o projeto de formação, principalmente quando discutem o currículo escolar. Para a coordenadora Maria Augusta, as discussões na JEIF deram aos professores o entendimento de que a aprendizagem da leitura e da escrita é um direito das crianças e não apenas uma questão de decodificação.

No entanto, a vivência dessa coordenadora não pode ser generalizada, este não é, para a maioria delas, um processo autônomo. Como já foi afirmado, ele vai sendo cerceado pela legislação, pelo projeto político da administração pública e por outros condicionantes, ligados à concepção de gestão do diretor e da equipe técnica, pelo envolvimento coletivo da equipe escolar, etc. Essa situação faz com que a coordenadora Maria Stella defina a autonomia da escola como parcial ou relativa. O que seria então uma autonomia relativa?

Uma possibilidade é compreender a autonomia relativa como flexível, possível e atingível, pois o limite dessa relatividade normalmente não está definido. Então, ainda que existam condicionantes para a elaboração dos projetos da unidade educativa, para que os projetos sejam legítimos, devem estar alicerçados no interesse comum. Assim, viver juntos num espaço público e político, como cidadãos, significa usar a 'relativa autonomia' em favor da vontade e da necessidade da coletividade. Contreras (2002, pp. 199,200), referindo-se à 
autonomia profissional do professor, faz uma reflexão que também pode ser aplicada à coordenação pedagógica e à escola. Segundo esse autor:

\begin{abstract}
A autonomia se desenvolve em um contexto de relações, não isoladamente. Tem a ver, portanto, com uma forma de manter relações. Consequentemente, as qualidades que estas relações reunirem são as que poderão favorecer ou entorpecer. Uma perspectiva de relação e construção da autonomia a define não como a posse de direitos e atributos, mas como a busca e a construção de um encontro pedagógico em que as convicções e pretensões abrem um espaço de entendimento no qual podem se desenvolver por meio do diálogo, tanto em sua significação como em sua realização. [...] a autonomia profissional não significa, dessa perspectiva o isolamento do restante dos colegas, nem tão pouco oposição à intervenção social na educação ou ao princípio de responsabilidade pública. Pelo contrário, a idéia de autonomia, entendida como exercício, como construção, deve se desenvolver em relação ao encargo prático de uma tarefa moral, da qual se é publicamente responsável, e que deve ser socialmente participada.
\end{abstract}

Neste aspecto, reconhecer a autonomia relativa da escola é conhecer seus limites e possibilidades, é trabalhar em prol de um projeto pedagógico coletivo que beneficie a comunidade atendida. Conforme o depoimento da coordenadora Maria Augusta, expresso no quadro anterior, é a consciência de uma necessidade coletiva que move a construção de um projeto de formação envolvendo toda a comunidade escolar, direcionado para o domínio da leitura e da escrita e inserido na conquista da cidadania. Esta última é maior que a formação específica, embora não a descarte, e constitui-se na base do projeto político pedagógico de cada escola.

Um projeto de escola bem definido inibe cerceamentos externos, é uma construção coletiva, que pressupõe certo acordo interno, o que não significa ausência de oposição para se atingir os objetivos que justificam as ações da comunidade educativa.

Do ponto de vista legal, as unidades educativas estão amparadas para, com suas peculiaridades de modalidade de ensino e de sistema educacional, pensarem objetivamente o seu projeto político pedagógico e, dentre suas muitas facetas, o desenvolvimento de seus profissionais.

No que tange, especificamente, ao Título IV da LDB - Da organização da educação nacional - no seu artigo 12, que enfoca as incumbências dos estabelecimentos de ensino, vale ressaltar que os Incisos I, II e IV destacam a responsabilidade das escolas por elaborarem e executarem sua proposta pedagógica, administrarem seu pessoal e velarem pelo cumprimento do plano de trabalho de cada docente. Tais determinações reafirmam a autonomia pedagógica 
e um projeto de formação contínua focado nas necessidades de cada escola, nas diretrizes do projeto político pedagógico. $\mathrm{O}$ artigo 15 deste mesmo Título determina:

Os sistemas de ensino assegurarão às unidades escolares públicas de educação básica que os integram progressivos graus de autonomia pedagógica e administrativa e de gestão financeira [...].

Com respeito ao desenvolvimento profissional dos docentes, o Titulo VI da LDB Dos profissionais da Educação - no artigo 61, aponta que:

[...] a formação de profissionais da educação, de modo a atender aos objetivos dos diferentes níveis, e modalidades de ensino e às características de cada fase do desenvolvimento do educando, terá como fundamentos: a associação entre teorias e práticas, inclusive mediante capacitação em serviço. (grifo nosso)

No artigo 67, os sistemas de ensino são conclamados a promover e assegurar a valorização dos profissionais de Educação, inclusive por meio de: "Aperfeiçoamento profissional continuado, inclusive com licenciamento periódico remunerado para esse fim" (Inciso II); e "[...] período reservado a estudos, planejamento e avaliação, incluído na carga horária de trabalho" (Inciso V).

A legislação educacional em vigor é um dos aspectos instituídos que precisa ser considerado na elaboração do projeto da escola, mas esse aspecto não descarta as características da própria cultura escolar como instituinte de metas, objetivos, modos de agir, hábitos e valores na instituição escolar. Essa situação exige uma escola que considera esses fatores na elaboração de seus projetos, portanto, uma escola que reflita sobre suas próprias concepções. Alarcão (2001, p. 15), ao definir uma escola reflexiva, afirma que:

[...] a escola que se pensa e que se avalia em seu projeto educativo é uma organização aprendente que qualifica não apenas os que nela estudam, mas também os que nela ensinam ou apóiam esses e aqueles.

Aos sistemas de ensino federal, estadual e municipal cabem organizar, segundo determinação legal, os espaços/tempos para que a formação aconteça, mas isso não descarta as interpretações, os equívocos e as formas predeterminadas para atingi-la. O texto legal não assegura políticas públicas que, efetivamente, garantam tais processos.

O projeto político pedagógico que se caracteriza como carta das intenções pedagógicas da escola, construído coletivamente para assegurar a autonomia da escola, pode propor formas 
de aprimoramento do trabalho desenvolvido pelos docentes, por meio de programas de formação contínua. Canário (2006, p. 75) corrobora essas ideias:

\begin{abstract}
A construção da autonomia dos estabelecimentos de ensino supõe uma capacidade autônoma de mudança que não é compatível com processos de controle remoto das escolas e dos professores, a partir da administração central. A formação "centrada na escola" é um das facetas de uma nova visão do estabelecimento de ensino, no qual ele é, simultaneamente, uma unidade estratégica de mudança e a unidade central de gestão do sistema. $\mathrm{O}$ projeto educativo da escola constitui o instrumento essencial de uma gestão estratégica do estabelecimento de ensino, cujas construção e avaliação, nas suas diferentes formas, configura-se como o eixo fundamental de um processo de formação contínua dos professores. É, portanto, em um plano mais global, balizado pelo projeto educativo da escola, que o plano de formação deve ser pensado.
\end{abstract}

Quando falamos em autonomia da escola, não estamos falando de 'soberania' da escola. A própria LDB trata de criar vínculos entre os sistemas de ensino e as determinações do plano de educação nacional, que nada mais é do que um plano político de trabalho.

O paradoxo é que a escola brasileira, que ainda sofre em decorrência de condições precárias, também é um lugar de formação para os educadores que lá atuam e que podem, de acordo com as condições dadas, realizar o exercício de repensá-la e de reavaliá-la para, dessa forma, buscar responder às necessidades da população que a ela tem acesso.

A organização da escola revela as opções ideológicas assumidas pelo coletivo escolar e comunica a cultura da escola. Assim, questões como trabalho coletivo, articulação da escola com a sua realidade local, organização didático-pedagógica, horário de funcionamento e tempo dedicado aos projetos de formação dos professores são estruturados a partir de uma luta política por condições ideais de trabalho pedagógico.

A educação escolar tem por base um projeto de intenções que ganha forma nos planos de trabalho de professores, coordenadores, diretores etc. Esses planos fazem parte de um processo de planejamento que é retomado e avaliado de tempos em tempos. O projeto de trabalho do coordenador pedagógico, bem como o próprio projeto de formação da escola, fazem parte desse grande plano de intenções. O projeto político pedagógico organiza e sistematiza todas as ações educativas da unidade escolar, inclusive a atuação formativa dos coordenadores pedagógicos que, ao gerir a formação, desenvolvem um plano de trabalho flexível e acordado com os professores em formação, pois considera as necessidades educativas dos alunos e dos professores numa temporalidade real. 
No entanto, não basta arrolar nesse documento o levantamento das necessidades formativas da comunidade escolar - alunos, professores e demais funcionários -, nem mesmo ter um profissional responsável para que ela ocorra. Para isso, são necessárias, também, algumas condições: previsão de tempo remunerado para estudo, uma liderança pedagógica para colocá-lo em prática, lugar para que os professores e/ou funcionários se reúnam, material para a reflexão, livros, DVDs, acesso à internet, palestras e outros que vão surgindo, dependendo do projeto formativo proposto pela escola:

O projeto tem que ser claro e refletir bem os caminhos da escola. Então, antes de escrever o projeto nós selecionamos as questões com os professores, fazemos as discussões, os levantamentos de prioridades e a organização do que vai acontecer [...]. Optamos por discutir primeiro e posteriormente elaborarmos o projeto. Ele tem que refletir, de fato, as necessidades da escola. (COORD. MARIA STELLA)

Assim, o projeto da escola norteia o seu trabalho e a sua flexibilidade garante a incorporação de novas demandas durante o ano letivo, o que possibilita mudanças, até mesmo na formação. Essas mudanças podem vir orientadas pelo sistema, na definição de sua organização e execução ${ }^{55}$. O grau de intervenção dependerá, conforme foi salientado, da consistência do projeto da escola.

A formação proposta no ambiente de trabalho não pode ser determinada nem pelo coordenador pedagógico nem pelo sistema, mas caracterizar-se como produto do processo reflexivo dos atores envolvidos. Cabe, assim, ao projeto político-pedagógico organizar as atividades educativas promovidas pela escola, no qual os planos de ensino, os planos de trabalho de seus profissionais e de formação devem estar inseridos. A formação, sendo contemplada no projeto da escola, torna-se a expressão da concepção e das decisões coletivas. Essa conjuntura possibilita ao coordenador pedagógico a busca das condições e dos conhecimentos para desenvolver o plano de formação construído a partir das necessidades apontadas pelo projeto educativo da escola.

\section{O PEA, configuração (ou não?) das decisões coletivas}

\footnotetext{
55 O "Guia de estudo para o horário coletivo de trabalho, subsídio para os coordenadores", publicado por SME/DOT em 2006, constitui-se em um exemplo da orientação fornecida pelos órgãos oficias ao coordenador para o trabalho com a formação contínua na escola.
} 
Enquanto o conceito de projeto político pedagógico tem um sentido de abrangência nacional, significando que é o plano que organiza as atividades da escola, o Projeto Especial de Ação (PEA) está associado a um conceito local, constituindo-se como um braço desse projeto mais abrangente nas escolas públicas municipais de São Paulo, configurando as intenções formativas da escola, estabelecendo a justificativa, os objetivos e os resultados a serem alcançados.

Na Rede Municipal de Ensino de São Paulo, o PEA dá sentido à atual Jornada de Tempo Integral de Formação (JEIF), pois configura-se no documento-síntese das intenções formativas de um determinado grupo de profissionais, em um tempo (histórico) e em um espaço (geográfico) específicos.

Os depoimentos das coordenadoras e dos professores envolvidos nos autorizam a elaborar o organograma a seguir. Segundo esses educadores envolvidos diretamente nos processos de formação na escola, como articuladores e participantes, o PEA é uma organização de formação complexa, que é marcado pela própria história da rede.

Sua organização pressupõe um movimento circular e contínuo, que parte da necessidade da escola, elencada por seus profissionais; agrega os saberes docentes, pois são os definidores das necessidades a partir de suas experiências; estuda a prática pedagógica, os saberes e fazeres dos educadores envolvidos; considera uma ou várias concepções de ensinoaprendizagem; trabalha em função da pesquisa e da reflexão com avaliações periódicas, sendo que a formação contínua, stricto sensu, ainda que organizada na forma de projeto, ocorre em diversos momentos dessa dinâmica.

A figura abaixo, elaborada a partir de alguns destaques dados pelas coordenadoras pedagógicas entrevistadas e por pesquisadores sobre aspectos a serem considerados na formação contínua na escola, agrega elementos da compreensão tanto de um como de outro profissional posicionados de formas diametralmente opostas, mas não em oposição uns aos outros. Representa, desse modo uma radiografia dos aspectos que compõem o projeto de formação nas escolas municipais de São Paulo.

\section{Aspectos constitutivos da formação centrada na escola}

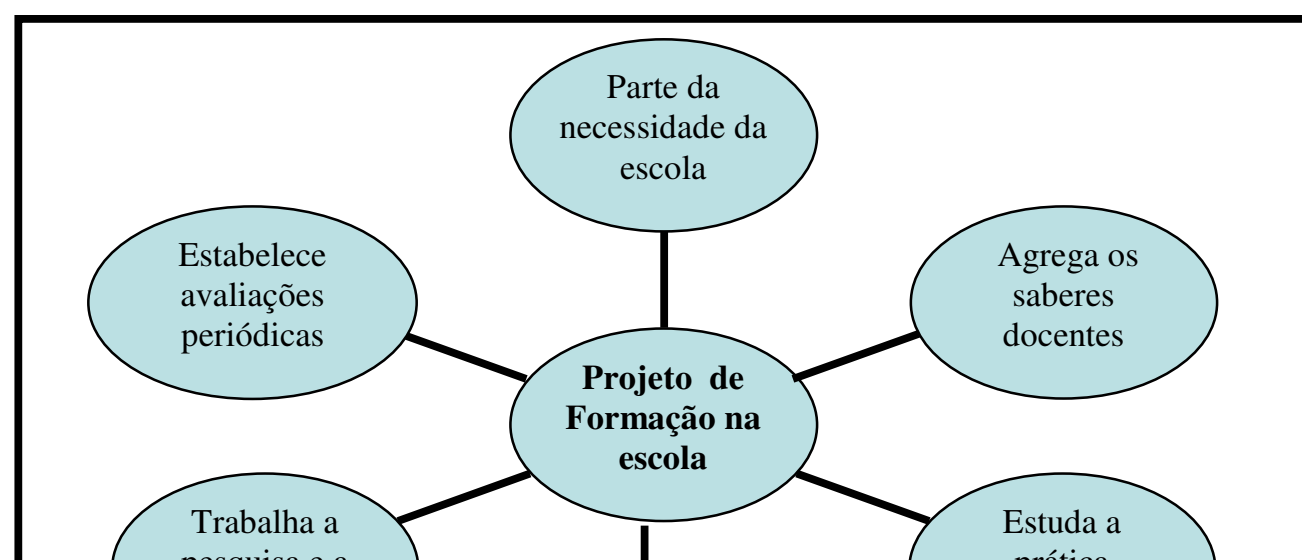


Quadro 08. Elaborado a partir da síntese dos dados da pesquisa e do referencial teórico

A tendência, conforme se observa no quadro anterior, é considerar a formação na escola como um processo circular que parte das necessidades da organização-escola portanto, de uma dimensão institucional e coletiva, considera a dimensão pessoal das experiências incorporadas na atividade docente (os saberes docentes) e objetiva a transformação na dimensão profissional, pela reflexão teórica e técnica sobre a prática educativa - e que, por fim, reapresenta o fechamento do círculo e a avaliação de novas necessidades.

Porém, tais aspectos se articulam de várias formas, não obedecendo uma seqüência específica, mas todos os fatores estão agregados ao projeto de formação da instituição escolar.

Esses fatores foram apresentados pelos professores, nos grupos dialogais, a partir de uma provocação hipotética relacionada à extinção da Jornada Especial Integral de Formação (JEIF). A proposta era que os professores, coletivamente, elencassem argumentos para a coordenadora pedagógica defender a permanência da JEIF em instâncias superiores. O resultado desta dinâmica foram argumentos pautados na idéia e existência de um 'PEA' de formação.

\section{Grupo I}

A jornada favorece a interação entre os docentes de diversas áreas, proporcionando projetos como a interdisciplinaridade, a aquisição de conhecimentos, o apoio mútuo entre os professores, criando um 'clima de segurança profissional' e oferece a oportunidade de formação continuada.

\section{Grupo II}

A jornada possibilita momentos para reflexão acerca de situações vivenciadas na educação, de trocas de experiências entre os pares, de preparação de aulas, para estudos, de elaboração de projetos coletivos, de atualização profissional, de integração entre os grupos e a equipe técnica, o que contribui para o enriquecimento das aulas e para a socialização de práticas pedagógicas. 


\section{Grupo III}

A jornada proporciona momentos: de reflexão e estudo sobre a prática pedagógica e sobre a teoria que a embasa, de troca de experiências entre os educadores a fim de responder ao PEA construído a partir do diagnóstico de problemas na escola.

\section{Grupo IV}

Este espaço garante estudos teóricos, troca de experiências entre os professores, reflexão em relação à prática cotidiana, além de planejamentos de ações coletivas e individuais, diagnósticos dos alunos e consequentes ações, colabora com a formação do grupo e a melhora da prática em sala de aula.

Em todas essas 'argumentações', a formação contínua torna-se uma justificativa para a existência dessa jornada (JEIF), implicando a elaboração de projetos formativos para esse horário, vinculados ao diagnóstico das dificuldades pedagógicas da escola. Os grupos apontaram em suas sínteses a necessidade de um projeto formativo vinculado à prática docente, visando à sua melhoria, ou seja, à aprendizagem dos alunos.

Os professores ressaltaram, em síntese, que a JEIF possibilita a formação contínua, ou seja, reflexão sobre situações vivenciadas, estudos, elaboração de projetos, socialização de práticas, troca de experiências, planejamento de ações coletivas e diagnósticos, todos esses aspectos comunicam uma organização de trabalho em que professores e coordenadores têm papéis complementares, mas não dicotomizados.

A idéia do PEA nasceu logo depois da institucionalização da antiga JEI, em 1992. Naquele tempo, a sigla PEA significava Projeto Estratégico de Ação e estava atrelada ao envolvimento de toda a comunidade educativa na resolução de um problema pedagógico, identificado pela equipe escolar. Posteriormente, passou a ser organizado por meio de Portarias que o caracterizavam e o restringiam.

A primeira Portaria do PEA, de $\mathrm{n}^{\circ}$ 2083, foi publicada em abril de 1994 e regulava a organização do projeto, até então, Projeto Estratégico de Ação, orientando o estudo da realidade local e caracterizando as possibilidades de projetos a serem desenvolvidos no horário coletivo, cujo foco estivesse na resolução dos problemas que dificultassem o trabalho pedagógico na escola.

A segunda Portaria de $\mathrm{n}^{\mathrm{o}} 3826$, de julho de 1997, modifica o nome para Projeto Especial de Ação, mantendo a sigla, subordinando-o ao projeto político pedagógico da escola e indicando algumas modalidades de PEAs, quais sejam, de formação e aperfeiçoamento profissional, de avaliação diagnóstica, de orientação educacional e pré-profissionalizante, de ações com a comunidade. 
A terceira Portaria de $\mathrm{n}^{\circ}$ 1654, de março 2004, determina duas modalidades de PEAs subdivididas em eixos de ações curriculares sistematizadas:

I- Formação Permanente da comunidade educativa, nos eixos:

a) aprofundamento da visão do currículo como construção sócio-cultural e histórica;

b) diversidade cultural, etno-racial, de gênero e de sexualidade;

c) cultura da infância, do adolescente, do jovem e do adulto;

d) leitura de mundo, alfabetização, letramento;

e) organização da escola em ciclos e a reestruturação dos tempos e espaços das unidades escolares;

f) paz e justiça social: direitos humanos, ética e cidadania;

g) educação para o meio ambiente;

h) avaliação.

II- Gestão democrática:

a) o protagonismo infanto-juvenil;

b) o fortalecimento dos grêmios estudantis;

c) o fortalecimento dos Conselhos de escola;

d) a participação efetiva de diferentes segmentos da comunidade educativa.

A quarta Portaria de $n^{\circ}$ 654, de fevereiro 2006, determina como ações de formação:

I- a tematização das práticas desenvolvidas em diferentes espaços educativos;

II- a articulação das diferentes atividades e/ ou projetos/ programas com as diversas instituições e conselho de escola que integram o Projeto Pedagógico;

III- a implementação dos Projetos e Programas específicos da Secretaria de Educação como: Programa "Ler e escrever - prioridade na escola Municipal", Programa "São Paulo é uma escola" e outros.

A quinta Portaria de $n^{\circ} 4.057$, de outubro de 2006, traz duas modificações: uma substituindo no inciso III, da Portaria anterior, o "Programa São Paulo é uma escola" pelo programa de formação de coordenadores pedagógicos da educação infantil, "Rede em rede: a formação continuada na educação infantil", e outra excluindo, no item docente, a participação dos professores adjuntos ${ }^{56}$, sem aulas atribuídas, dos projetos de formação.

Por fim, a Portaria $\mathrm{n}^{\circ}$ 1566, de março 2008, traz uma nova redação ao artigo primeiro, fazendo menção à necessidade de ser contemplado nos projetos de formação desenvolvidos na escola os projetos da Secretaria Municipal de Educação. A mudança mais significativa é a alteração do inciso III, da portaria anterior, com o acréscimo da determinação de implementação dos documentos de "Orientações Curriculares: expectativa de aprendizagem

\footnotetext{
56 Atualmente, na Rede Municipal de Ensino de São Paulo não há mais professores adjuntos. Todos os professores adjuntos tiveram seus cargos 'transformados' em professores titulares. Os que não têm uma turma atribuída trabalham compondo o módulo da escola, ou seja, durante a jornada de 30 horas-aula participam de todos os projetos pedagógicos da escola, exceto os da formação.
} 
e orientações didáticas" e do "Referencial sobre avaliação da aprendizagem de alunos com necessidades educacionais especiais".

Tais documentos moldam os projetos das escolas, que passam a ter a mesma estrutura organizacional e de conteúdo, deixando pouco espaço para a construção de projetos autônomos que respondam às dificuldades levantadas pela equipe escolar. Ademais, orientam de forma muito diretiva o trabalho de formação desenvolvido pelo coordenador pedagógico na escola.

$\mathrm{O}$ quadro a seguir procura sistematizar os depoimentos das coordenadoras que se referiam diretamente ao PEA. As categorias organizadas revelam aspectos redundantes nesses depoimentos e que, também, são reveladores do sentido desse projeto para as escolas.

O projeto especial de ação (PEA) - a proposta de formação da escola

\begin{tabular}{|c|c|}
\hline $\begin{array}{c}\text { LEVANTAMENTO } \\
\text { DAS } \\
\text { NECESSIDADES }\end{array}$ & $\begin{array}{l}\text { "O tema do PEA era comum, isso facilitou, todo mundo sabia que o problema } \\
\text { era alfabetização. Quando as crianças chegam ao ciclo II, todos veem que o } \\
\text { problema é a leitura e a escrita, então, a proposta era trabalhar a alfabetização - } \\
\text { a leitura e a escrita. Posteriormente, os professores refletiram e concluíram que } \\
\text { a expressão 'Leitura e escrita' já abarcava alfabetização, não precisa estar } \\
\text { citando o termo. O projeto (PEA) funcionou porque partiu de uma necessidade } \\
\text { da comunidade escolar". (COORD MARIA VITÓRIA) } \\
\text { "Quando organizamos um PEA, acabamos montando de acordo com a } \\
\text { dificuldade do grupo, o que eles acabam dizendo, avaliando. Logo que cheguei } \\
\text { à escola, li as avaliações da unidade e as sugestões de encaminhamento para o } \\
\text { ano que viria. Então foi partindo da avaliação que o grupo fez, das dificuldades } \\
\text { que eles tinham que pensamos o PEA para aquele ano". (COORD. MARIA } \\
\text { LEDA) }\end{array}$ \\
\hline \multirow[t]{2}{*}{$\begin{array}{l}\text { TRABALHO } \\
\text { COLETIVA }\end{array}$} & $\begin{array}{l}\text { "Quando eu cheguei, já haviam tido uma discussão em relação à quantidade de } \\
\text { projetos, que deveria haver menos projetos e todos voltados para a necessidade } \\
\text { maior da escola, que era a questão da alfabetização, esse era o ponto central". } \\
\text { (COORD MARIA VITÓRIA) } \\
\text { "Esse ano nós organizamos os grupos de JEI, nos horários coletivos, e fomos } \\
\text { avaliando o PEA do ano passado e pensando nos encaminhamentos para esse } \\
\text { ano. Então, a partir daí demos uma continuidade em alguns temas, mas também } \\
\text { organizamos assuntos que não foram trabalhados no ano anterior. Mesmo as } \\
\text { salas ambientes que foram desmontadas, nessa nova proposta, quando foram } \\
\text { organizadas, foi em virtude de uma demanda, e não apenas por vontade de } \\
\text { alguém que quis fazer assim". (COORD. MARIA LEDA) }\end{array}$ \\
\hline & $\begin{array}{l}\text { “Quando nós escrevemos o projeto, esse ano, percebemos que o projeto estava } \\
\text { com a cara da prefeitura, que é o 'Programa Ler e Escrever' [...]. Neste ano foi } \\
\text { praticamente imposto, o horário coletivo é isso: quatro horas para o 'Programa } \\
\text { Ler e Escrever' e as outras quatro para o projeto da escola e o 'Programa São } \\
\text { Paulo é uma escola' [...]. Não está sendo uma experiência fácil para nós, não }\end{array}$ \\
\hline
\end{tabular}




\begin{tabular}{|c|c|}
\hline $\begin{array}{c}\text { FATORES QUE } \\
\text { INTERFEREM NO } \\
\text { PEA }\end{array}$ & 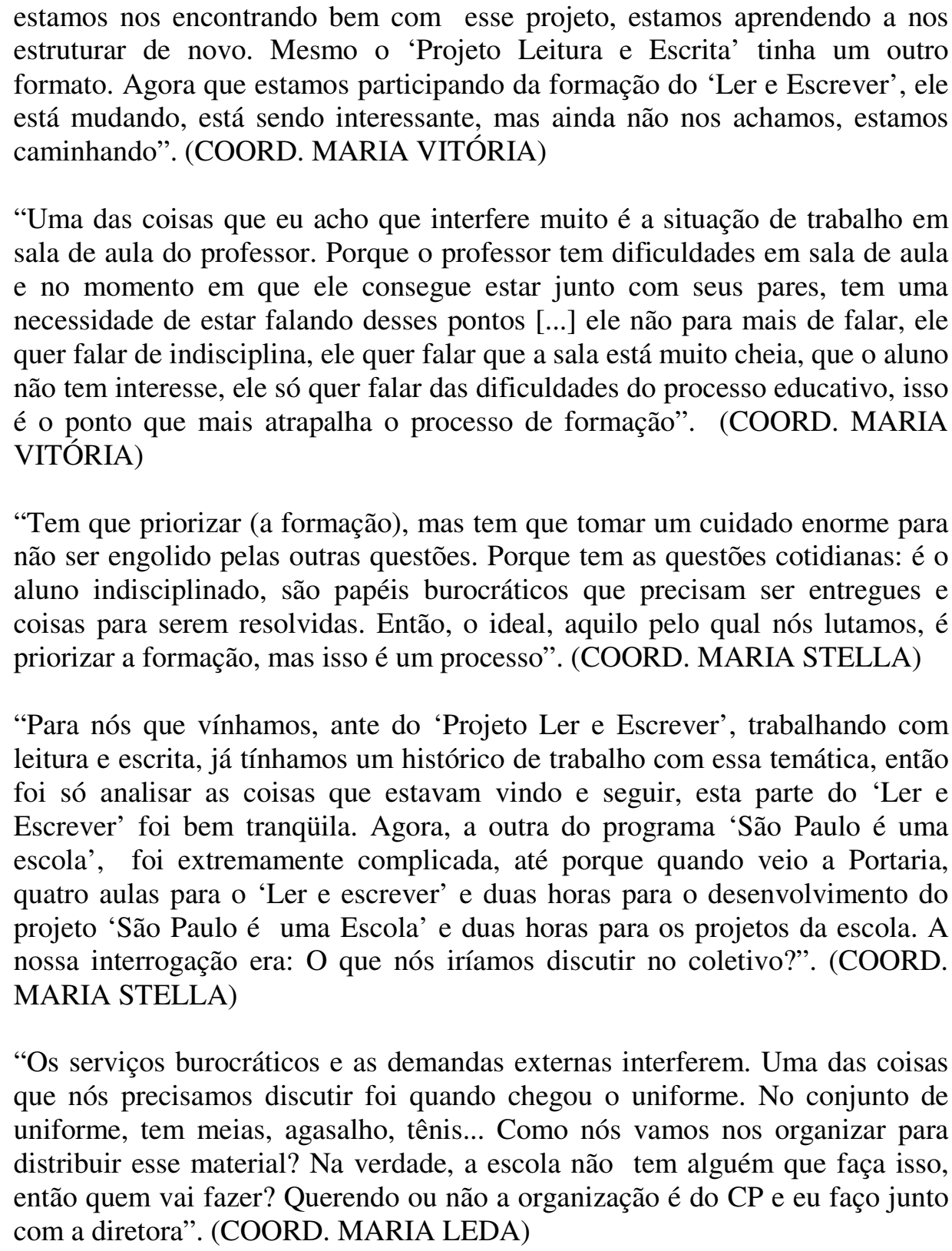 \\
\hline $\begin{array}{l}\text { AS PRÁTICAS } \\
\text { DOCENTES }\end{array}$ & $\begin{array}{l}\text { "Na verdade o que a gente mais faz aqui é refletir sobre a própria prática. [...] } \\
\text { Uma forma de reflexão é através das atividades das crianças, outra é o } \\
\text { envolvimento delas. Nós percebemos quando o professor se envolve e quando } \\
\text { ele só faz as coisas de praxe. Quando ele se envolve ele pensa as atividades. } \\
\text { Por exemplo, se eu estou estudando artes, quando eu vou pensar artes visuais } \\
\text { dentro do meu projeto, eu penso em atividades mais avançadas do que eu } \\
\text { fazia". (COORD. MARIA LEDA) } \\
\text { "Quando eu fui para lá [...] no terceiro período havia três turmas do terceiro } \\
\text { ano do ciclo um, que pareciam que nunca tinham entrado na escola. Eles não } \\
\text { sabiam ler ou escrever, coisa de abandono, e a primeira coisa que falei foi que } \\
\text { 'ninguém nunca disse ao professor que deixasse de ensinar', essa é uma } \\
\text { questão básica do professor, não estamos discutindo aqui se é moderno, } \\
\text { construtivista, tradicional, sei lá o quê, essa discussão não interessa aqui. Para } \\
\text { as crianças aprenderem a ler não existe magia, para isso os professores têm } \\
\text { que assumir o seu papel, têm que ensinar. Então, nós vamos arrumando, }\end{array}$ \\
\hline
\end{tabular}


discutindo, refletindo e analisando e eles vão melhorando". (COORD. MARIA AUGUSTA)

Quadro 09 . Elaborado a partir dos depoimentos das coordenadoras entrevistadas

No quadro anterior, é evidente que há uma sobreposição dos depoimentos das coordenadoras sobre o PEA e sobre as categorias levantadas. Na verdade, coerentemente, os discursos repetidos pelas coordenadoras entrevistadas revelam uma organização dos projetos formativos, que acentua certas contradições, algumas mais evidentes nas escolas de ensino fundamental do que de educação infantil.

Os PEAs, segundo o relato das coordenadoras da EMEF, partiam de um levantamento das necessidades da escola local, com discussões internas, que desvelavam as dificuldades em relação à aprendizagem da leitura e da escrita. Os projetos, então, procuravam estudar e entender essas dificuldades pautadas em: uma didática coerente com o modo como as crianças constroem conhecimentos lingüísticos e em materiais teóricos produzidos institucionalmente, como os do PROFA ${ }^{57}$. Outros grupos, especialmente no ciclo II, entendiam que o estudo da tipologia textual daria base para que os professores das diferentes áreas do conhecimento compreendessem o tipo de texto produzido em sua disciplina, favorecendo a busca por uma metodologia que possibilitasse o trabalho com a leitura e a escrita em todas as áreas.

Cada coordenador e cada escola foram organizando paulatinamente, com os recursos que detinham, uma formação a partir da necessidade e das competências observadas no grupo, com uma identidade própria. A intervenção do sistema, por meio das portarias organizadoras do PEA, acabou por desconstruir essas conquistas, negando os saberes de cada unidade. Não se tratou de somar outros saberes aos conhecimentos elaborados pelas equipes, mas de pulverizar, de forma homogênea, um conhecimento e uma prática que não consideraram os saberes e as práticas locais. Os depoimentos dos professores ${ }^{58}$ foram mais contundentes ao apresentar essa realidade, referindo-se a essa ingerência como "imposição teórica” e denunciando a ausência de diálogo do órgãos oficias com a escola.

A formação genérica proposta para a escola, pautada no "Programa Ler $e$ Escrever”, acaba nivelando, em todas as unidades, a discussão sobre a aprendizagem da leitura e da escrita, desconsiderando, nesse processo, o percurso de cada escola. Mesmo sendo

$57 \quad$ Programa de Formação dos Professores Alfabetizadores, curso optativo, oferecido entre 2001 e 2004 aos professores e aos coordenadores, da Rede Municipal de Ensino de São Paulo, que contava com apostilas e fitas de vídeo que orientavam a discussão nos cursos de formação. 
a perspectiva do problema semelhante, ainda assim não houve valorização das elaborações oriundas das vivências escolares. Os problemas relativos à alfabetização das crianças, nesta modalidade formativa, passam a estar diretamente relacionados ao fato de os professores não planejarem as tarefas adequadamente.

Existe uma 'coincidência', fruto das pesquisas e do acompanhamento, entre os problemas pedagógicos detectados pela Secretaria Municipal de Educação e os identificados pela escola. Ambos estão preocupados com a aprendizagem da leitura e da escrita pelas crianças matriculadas nas escolas municipais. Esse aspecto é facilmente observado no quadro anterior, na categoria 'fatores que interferem'.

Nestes últimos anos, a opção da Rede Municipal de Ensino de São Paulo, para melhorar o trabalho desenvolvido junto às crianças e jovens foi investir na formação do professor. Esse processo esteve pautado na ação do coordenador pedagógico, desenvolvida no horário coletivo e alicerçada no repasse das discussões e tarefas, antes socializadas nas reuniões de formação oferecidas ao coordenador e na utilização das publicações criadas para subsidiar o trabalho do professor com a leitura e a escrita. Essa dinâmica parece não deixar um espaço para a consideração dos projetos pré-existentes nas escolas, dando-lhes suporte.

As coordenadoras Maria Vitória e Maria Stella relatam que as escolas já tinham projetos relativos à aprendizagem da leitura e da escrita em andamento e tiveram que se reestruturarem para se adequarem às novas exigências. Uma perda de tempo e de energia, pois tais medidas acabam por descaracterizar esses projetos e, dessa forma, promovem um prejuízo para as identidades construídas. Os professores majoritariamente, quando consultados sobre o que desprezariam no trabalho de formação na escola, apontaram a intervenção dos projetos externos, propostos por SME, na escola.

Durante a observação, foi possível acompanhar a preocupação da coordenadora Maria Vitória com que os professores se apropriassem do recurso denominado 'sequência didática'. De forma sistemática, a cada encontro, era retomada a discussão sobre essa temática com apresentações de sequências pela coordenadora, pelo grupo ou em vídeo. Alternadas com esses momentos, a avaliação procurava determinar os avanços dos alunos em relação à aprendizagem da leitura e da escrita. Porém, durante os dois semestres observados, a sequência didática foi sempre retomada como um exercício e não como a análise de uma prática pedagógica regular. Tal atitude revelava um quadro de resistência dos professores, em relação à formação proposta, que se manifestava na negação de transformar em prática 
cotidiana esse modo de organização do trabalho docente. Orsolon (2005, p. 21), em sua reflexão sobre a mudança na escola e o papel do coordenador, traz considerações que tocam na questão apontada:

A mudança na escola só se dará quando o trabalho for coletivo, articulado
entre todos os atores da comunidade escolar, num exercício individual e
grupal de trazer as concepções, compartilhá-las, ler as divergências e as
convergências e, mediante esses confrontos, construir o trabalho. O
coordenador como um dos articuladores desse trabalho coletivo, precisa ser
capaz de ler, observar e congregar as necessidades dos que atuam na escola;
e, nesse contexto, introduzir inovações, para que todos se comprometam
com o proposto.

Outro aspecto observado foi a ausência de uma diversificação bibliográfica, principalmente na Escola $\mathrm{A}$, que ficou restrita às publicações produzidas pela Secretaria Municipal de Educação de São Paulo e oferecidas aos professores e aos coordenadores. Esse material cumpriu a tarefa de divulgar a concepção pedagógica que norteava o trabalho das equipes da secretaria e orientar a ação dos profissionais na escola (professores, diretores e coordenadores), generalizando conceitos, pautados na sistematização de uma metodologia de trabalho.

A fala da coordenadora Maria Vitória, no quadro anterior, mais especificamente na categoria 'fatores que interferem no PEA', é emblemática de como os programas de governo, na perspectiva das coordenadoras, podem ser implementados de forma a desconsiderar o percurso dos envolvidos e dificultar o trabalho de formação na escola: "Não está sendo uma experiência fácil, não estamos nos encontrando com esse projeto, estamos aprendendo a nos estruturar de novo".

Tais dizeres refletem um descaso com o tempo e os conhecimentos produzidos nas práticas dos coordenadores pedagógicos que, nessa dinâmica, passaram a duvidar das suas competências e de seus saberes. Situação essa revelada pela questão proposta pela coordenadora Maria Stella: "O que iremos discutir no coletivo?" Esta pergunta retórica reflete a desarticulação entre o que a escola pensava em termos de formação e a proposta da Secretaria Municipal de Educação. Pode, ainda, ser uma formulação preocupada com o pouco tempo que sobra para a escola refletir sobre a sua organização, os projetos locais. $\mathrm{Ou}$, a manifestação de uma desorientação, "se tudo o que foi realizado estava errado, o que iríamos discutir agora?" 
A observação da condução dos PEAs pelas coordenadoras revelou uma reflexão mais pautada na apropriação de um modo de organização didática (como fazer) do que nas experiências pedagógicas vivenciadas no cotidiano (os fazeres).

A proposta de formação centrada na escola é bastante atual na Rede Municipal de Ensino de São Paulo. Ter o coordenador como articulador nesse modelo torna-a possível. Porém, se ele desconsiderar os saberes construídos pelo grupo de professores, essa possibilidade se perde. Mesmo que a formação esteja centrada na escola, se as decisões sobre ela, configuradas no PEA, fogem desse domínio, acaba reforçando, ainda que de modo indireto, a dicotomia entre a teoria e a prática, pouco discutida com o coordenador. A escola passa a desenvolver uma formação pensada fora dela. São as avaliações diagnósticas e as sequências didáticas, com os seus 'antes, durante e depois', muito bem elaboradas pelos professores, que, nesta perspectiva, poderão garantir a aprendizagem das crianças.

Mas o que fazem os professores? Alguns não ensinam, conforme insinuação da coordenadora Maria Augusta no quadro anterior, não assumem o seu papel de ensinar, "Para as crianças aprenderem a ler não existe magia, para isso os professores têm que assumir o seu papel, têm que ensinar. Então, nós vamos arrumando, discutindo, refletindo e analisando e eles vão melhorando", porém ela vê uma saída no processo de formação, que possibilita a discussão, o diálogo, a análise e a reflexão. É nesse processo coletivo que os professores e os coordenadores vão melhorando os seus fazeres. É a prática real refletida que promove uma transformação de saberes e saberes-fazeres para melhor.

Mas que abordagem deve ser adotada? Como tornar a prática alvo de análise e reflexão? Quais conceitos, quais saberes o coordenador precisará desenvolver para que a formação produza sua autonomia intelectual? Onde fica o espaço de singularidade num PEA que é igual para todas as escolas?

A coordenadora Maria Augusta relatou como conseguiu, junto com outras coordenadoras, criar uma rede de formação entre escolas e formular um projeto próprio de formação para professores, gerido pelas unidades educativas envolvidas, com participação de profissionais externos, alguns associados à universidade e outros profissionais de notório saber. A natureza interescolar cumpre o papel de uma socialização mais ampla entre sujeitos diversos (outros formadores que não o $\mathrm{CP}$, outros colegas que não os da escola de origem), um processo que é autônomo e apoiado no PEA da escola.

Em outra escola, foi observado que, mesmo tendo desenvolvido projetos formativos organizados in loco, a equipe escolar não confiava na eficácia dos mesmos, aceitando o programa instituído pela secretaria de educação como melhor do que o já 
existente. O que poderia ser uma troca de experiência crítica tornava-se um processo de treinamento pautado pela repetição de modelos. Embora demonstrasse uma boa articulação com o grupo de professores, a coordenadora não percebia a insatisfação dos mesmos com aquela dinâmica, ou, se o sabia, entendia que o que estava sendo ofertado era o melhor para aquele grupo. Posteriormente o grupo de professores teve a chance de manifestar-se e posicionar-se contra o que chamaram de "imposição de uma teoria sobre o que já faziam".

A contradição era que o trabalho dessa coordenação estava orientado pelo PEA, mas esse estava comprometido com as ideias de uma formação que não considerava as especificidades do locus formativo, nem os saberes docentes. No entanto, o discurso pessoal da coordenadora era de valorização dos saberes do grupo, considerado envolvido com a aprendizagem dos alunos.

Assim, como os professores denunciaram estratégias formativas organizadas a partir de uma concepção que não prima por uma produção que favoreça a construção de um trabalho autônomo pelo docente, a coordenadora Maria Augusta registra uma possibilidade de organização formativa, estruturada numa ação coletiva interescolar, que aglutina unidades educativas. Por se constituírem as unidades educativas próximas umas das outras, cria-se um elo que consegue agregar e envolver, ainda mais, na avaliação dessa coordenadora, os docentes.

Projetos de formação de professores centrados na escola - já antes referido implicam uma valoração da prática como detentora de saberes, ainda que tácitos, e numa aproximação das dificuldades da escola. Marcelo Garcia (1999) identifica a idéia da profissionalização docente na escola com o reconhecimento da capacidade docente de tomar decisões profissionais e da escola propor autonomamente seus próprios projetos formativos.

Analisando os relatos nas entrevistas e a observação das práticas das coordenadoras no PEA foi possível vislumbrar duas configurações de formação ligadas à subjetividade das participantes em relação ao espaço formativo. Tais idéias foram sintetizadas no quadro que segue e que revela duas formas de caracterização dos projetos de formação centrados na escola.

Configurações do trabalho com o PEA

\begin{tabular}{|c|l|l|l|}
\hline & \multicolumn{2}{|c|}{$\begin{array}{c}\text { PEA - em prol da autonomia } \\
\text { profissional docente }\end{array}$} & $\begin{array}{l}\text { PEA - como instrumento de } \\
\text { socialização } \\
\text { educativas }\end{array}$ \\
\hline $\begin{array}{c}\text { Modelo de } \\
\text { formaçãa }\end{array}$ & $\begin{array}{l}\text { Centrado na escola, pautado pela } \\
\text { autonomia das equipes. }\end{array}$ & $\begin{array}{l}\text { Centrado na escola, pautado no } \\
\text { controle dos resultados. }\end{array}$ \\
\hline
\end{tabular}




\begin{tabular}{|c|c|c|}
\hline $\begin{array}{c}\text { Fonte de } \\
\text { aprendizagem }\end{array}$ & $\begin{array}{l}\text { Projeto formativo organizado pela } \\
\text { equipe escolar a partir dos problemas } \\
\text { pedagógicos detectados e articulado pelo } \\
\text { coordenador pedagógico, lotado na } \\
\text { escola. }\end{array}$ & $\begin{array}{l}\text { Projeto formativo elaborado a partir } \\
\text { dos projetos educativos de governo e } \\
\text { articulado pelo coordenador } \\
\text { pedagógico, lotado na escola. }\end{array}$ \\
\hline Tempo/espaço & $\begin{array}{l}\text { Jornada Especial Integral de Formação } \\
\text { (JEIF). }\end{array}$ & $\begin{array}{l}\text { Jornada } \quad \text { Especial } \text { Integral } \mathrm{de} \\
\text { Formação (JEIF). }\end{array}$ \\
\hline $\begin{array}{c}\text { Tipo de } \\
\text { atividade }\end{array}$ & $\begin{array}{l}\text { Pesquisa, análise e reflexão sobre a } \\
\text { prática. }\end{array}$ & $\begin{array}{l}\text { Análises de práticas a partir de } \\
\text { publicações institucionais. }\end{array}$ \\
\hline $\begin{array}{l}\text { Atitude dos } \\
\text { participantes }\end{array}$ & $\begin{array}{l}\text { Participam da formulação e do processo } \\
\text { de formação e avaliam os resultados. }\end{array}$ & $\begin{array}{l}\text { Recebem a orientação externa sobre } \\
\text { a organização do projeto (forma, } \\
\text { conteúdo, desenvolvimento e } \\
\text { avaliação). }\end{array}$ \\
\hline $\begin{array}{l}\text { Características } \\
\text { dos } \\
\text { participantes }\end{array}$ & $\begin{array}{l}\text { Sujeitos que têm saberes e que são } \\
\text { capazes de re-elaborar seus próprios } \\
\text { conhecimentos e melhorar suas práticas. }\end{array}$ & $\begin{array}{l}\text { Sujeitos que precisam ter bons } \\
\text { modelos para melhorar suas práticas } \\
\text { e possibilitar a aprendizagem dos } \\
\text { alunos. }\end{array}$ \\
\hline O que se espera & $\begin{array}{l}\text { Desenvolvimento de uma prática crítico- } \\
\text { reflexiva em relação à ação docente, em } \\
\text { prol da aprendizagem dos alunos. }\end{array}$ & $\begin{array}{l}\text { Desenvolvimento de competência } \\
\text { didática, em prol da aprendizagem } \\
\text { dos alunos. }\end{array}$ \\
\hline
\end{tabular}

Quadro 10. Elaborado a partir da análise dos depoimentos dos participantes da pesquisa em relação ao PEA

O quadro acima mostra a dualidade de ações formativas que, embora tenham como foco a aprendizagem dos alunos, são organizadas de forma diversa, o que manifesta concepções diferentes sobre o trabalho com a formação contínua do docente na escola. Uma que corresponsabiliza o professor pela sua formação e os resultados dela na prática pedagógica e outra que busca apenas instrumentalizar o professor para determinadas ações curriculares.

Analisando os dados, é possível afirmar que professores e coordenadores apresentam experiências educativas que os tornam incomodados com a atual situação das propostas formativas na escola, pois, da forma como vem sendo organizadas, cada vez mais excluem as equipes escolares de uma participação incisiva nas decisões sobre a formação a ser desenvolvida na escola.

\section{O trabalho de formação compartilhado - o diretor e o supervisor como parceiros no trabalho do coordenador na formação escola}


O trabalho de gestão do projeto político pedagógico, especialmente a formação contínua na unidade escolar, não é responsabilidade exclusiva do coordenador pedagógico. Segundo Libâneo (2003, p.29), "O desenvolvimento profissional e a conquista da identidade profissional dependem de uma união entre pedagogos especialistas e os professores, assumindo juntos a gestão do cotidiano da escola, o processo de ensino e aprendizagem, a avaliação." Libâneo (2003) usa a expressão "pedagogos especialistas", referindo-se ao trabalho do supervisor escolar ${ }^{59}$, do diretor, do orientador educacional e do coordenador pedagógico, que ao desenvolverem um trabalho conjunto e partilhado asseguram que a organização escolar torne-se um ambiente de aprendizagem também para professores, um espaço/tempo de reflexão e de organização de novas práticas.

Como foi apresentado no segundo capítulo, outros profissionais foram, no decorrer da história, assumindo o papel de acompanhar o desenvolvimento pedagógico e prover a formação contínua do docente, entre eles o diretor e o supervisor, além de outros técnicos.

Nas escolas municipais, os coordenadores pedagógicos, historicamente, estão numa posição de interlocução direta entre as concepções pedagógicas do sistema de ensino, os conhecimentos docentes e as necessidades educativas da comunidade escolar. Nessa relação, também estão implicados o supervisor e o diretor de escola.

A partir da década de 1980, com a democratização da educação no Brasil, os papéis do diretor e do supervisor escolar vêm sendo re-significados. Normalmente, relacionado a uma concepção técnica de mando e inspeção, passam a ser entendidos, pelos pesquisadores, como articuladores das relações colaborativas na escola. Ocorre, assim, uma aproximação entre diretores, coordenadores e supervisores no trato das questões pedagógicas.

Os atuais gestores ${ }^{60}$ do sistema de ensino municipal de São Paulo deram um novo enfoque a esse tema relativamente antigo, ao proporem a idéia de um trio gestor, referindo-se à ação 'conjunta' do supervisor, diretor e coordenador na gestão pedagógica na escola.

Os depoimentos das coordenadoras mostraram que a presença desses atores podem, em maior ou menor grau, dificultar ou facilitar o trabalho do coordenador pedagógico. De forma geral, os diretores são considerados como parceiros no trabalho de acompanhamento pedagógico, especialmente, o de formação contínua na escola. No entanto, os supervisores não são lembrados como parceiros do trabalho escolar. Normalmente sua ação está associada à inspeção, aprovação ou cobrança em algum nível.

59 Sobre o papel do supervisor escolar, consultar Franco (2007). 
O supervisor, como um dos braços da gestão pública, é um profissional que não pode estar apenas comprometido com as questões relativas ao cumprimento da legislação municipal, pois tem responsabilidades com a articulação entre os conhecimentos e os projetos que permitem atender as escolas nas suas necessidades. Muitos supervisores não se habilitam a acompanhar o processo de formação porque não sabem o que dizer, pois seus conhecimentos são genéricos, haja vista que acompanham um número significativo de escolas de diferentes níveis, então a maioria atém-se a cobrar as determinações do poder público.

Nos últimos tempos, o número de supervisores nas Diretorias Regionais de Educação (DRE) tem dobrado, isso em virtude da expansão da rede física e de recente concurso para provimento desse cargo. Apesar disso, as visitas da supervisão ainda têm um caráter mais administrativo do que pedagógico.

Um espaço/tempo compartilhado favorece o envolvimento de todos os atores na discussão e na construção de um ambiente democrático que cumpra a função da escola como socializadora de conhecimento. A coordenadora Maria Augusta faz uma reflexão bastante oportuna sobre este aspecto:

Eu acho que escola é uma construção coletiva. Não sou eu que faço a escola, nem o diretor, é o conjunto. Algumas idéias são minhas, outras do diretor e outras dos professores, que a gente vai alimentando, dando formato até virar algo concreto.

A análise empreendida por essa coordenadora aponta a responsabilidade de todos na construção de uma escola pública de qualidade. Juntos a equipe escolar, a direção, a coordenação e a supervisão vão dando concretude aos projetos, à medida que alimentam as ideias, adequando-as às necessidades da escola desejada.

\subsection{O diretor, componente da equipe pedagógica}

Segundo Barros (2004), o cargo de diretor de escola surgiu, formalmente, no estado de São Paulo, associado à expansão do ensino que caracterizou a mudança do regime monárquico para o regime republicano. A autora salienta que, naquela época, final do século

60 Chamamos de atuais gestores os membros da equipe de Divisão de Orientação Técnica (DOT) central, responsáveis, junto ao Secretário Municipal de Educação, Alexandre Alves Schineider, pela organização dos projetos pedagógicos da Secretaria Municipal de Educação, de 2005 a 2008. 
XIX, o diretor tinha suas funções ligadas à reforma educacional, produto do verticalismo das relações entre o sistema de ensino e a escola.

Silva Junior (1993) identifica na ideia de direção de escola uma linha tradicional, mais ocupada com os aspectos administrativos do que educacionais. Contudo, para esse autor, a ação administrativa deve considerar que tem como ponto de chegada a educação.

Os depoimentos, durante a investigação, demonstraram que só quando o diretor enxergava em sua ação uma finalidade pedagógica, em função do projeto educativo da unidade, é que o trabalho do coordenador tende a ser referendado, o que facilita o desenvolvimento das ações desse profissional, em especial, a formação centrada na escola.

A coordenação pedagógica, na forma como está configurada atualmente, em São Paulo, é uma elaboração relativamente recente no cenário educacional brasileiro. Antes, essa função era desenvolvida pelo supervisor escolar (de sistema), em conjunto com o diretor de escola e, posteriormente, pelo assistente pedagógico. Archangelo (2005) atribui a presença do coordenador na escola a uma reivindicação do diretor que, cada vez mais envolvido com um trabalho burocrático-administrativo, teria sido levado a abdicar de sua tarefa mais diretamente pedagógica. Os depoimentos das coordenadoras corroboram essa idéia:

O diretor perde-se no burocrático, fica ali naquelas questões, nos problemas emergenciais, não que nós não façamos isso, fazemos sim, mas o diretor tem as questões de verbas, os processos, o grupo de agentes escolares, de secretaria, parece que não tem uma unidade de trabalho. Então, eu ainda acho que o coordenador, com todas as suas dificuldades, é quem trabalha com o melhor da escola, que é o processo pedagógico. (COORD. MARIA VITÓRIA)

O diretor tem que ter liderança sobre a equipe de professores e funcionários. Ele tem que ter uma visão muito ampla do processo todo, tem que pensar muito, porque por mais pedagógico que um diretor seja, tem as questões burocráticas que estão sempre ali, processos para ver, além de outras demandas. (COORD. MARIA STELLA)

Mesmo ocupando-se de tarefas mais administrativas e burocráticas, o diretor de escola tem sua função diretamente ligada ao pedagógico e seu distanciamento ou aproximação está associado às diferentes concepções de gestão da escola, às demandas de trabalho desse profissional, à relação estabelecida com o coordenador pedagógico e ao projeto desenvolvido na unidade educativa. Libâneo (2003, p. 88) afirma que:

O diretor ou diretora de escola tem, pois, uma importância muito significativa para que a escola seja respeitada pela comunidade. Como temos 
insistido, autonomia, participação, democracia não significam ausência de responsabilidades. Uma vez tomadas as decisões coletivamente, participativamente, é preciso colocá-las em prática.

De fato, não é necessário que o diretor desenvolva a função do coordenador, estando esse presente, mas é necessário que o trabalho seja uma construção coletiva, apoiado pelo diretor, que deve acompanhá-lo. Os depoimentos das coordenadoras trazem elementos para que se pense a relação entre direção e coordenação pedagógica na condução dos trabalhos de formação na escola. Para elas essa relação pode ser facilitadora ou dificultadora do trabalho:

Em 2001 assumimos os trabalhos na escola eu, a outra coordenadora, a diretora e a assistente - uma equipe toda nova - que desde o começo esteve junta. Eu não vivi as experiências que já ouvi relatada, de coordenadores em pé de guerra com os diretores e de diretores cerceando o trabalho dos coordenadores. $\mathrm{O}$ diretor diz uma coisa e o $\mathrm{CP}$ outra. $\mathrm{O}$ coordenador torna-se 'o recheio do sanduíche', entre os professores e o diretor. Se não houver uma boa direção, no sentido da conversa e do apoio, o trabalho não flui. A direção pesa muito. Outra coisa que pesa é ter uma boa relação com a outra coordenadora, estar sempre conversando e trocando ideias. Eu acho que isso colaborou muito para a construção do meu trabalho, porque não foi um processo solitário. Nós dialogamos com a direção, que apoia o nosso trabalho, e isso ajuda muito. (COORD. MARIA STELLA)

Era uma diretora horrível que estava lá, ela era eleita, escolhida pela equipe da escola, uma coisa horrorosa. Via os alunos como uns coitados. (COORD. MARIA AUGUSTA)

Dos dois depoimentos acima, um relata o confronto com uma direção autoritária. Nesse caso, a coordenadora narra que a diretora nada fazia para facilitar o trabalho docente e contribuir com o desenvolvimento dos alunos, que eram vistos como coitados, incapazes. Porém, mesmo essa coordenadora vai dizer, referindo-se a outro diretor, que ele é um grande aliado no desenvolvimento do trabalho pedagógico da escola. Fusari (2007, p.22) afirma que:

A formação contínua de educadores que atuam na escola básica será bem mais sucedida se a equipe escolar, liderada pelos diretores e coordenadores pedagógicos [...], encará-la como valor e condição básicos para o desenvolvimento profissional dos trabalhadores em educação.

A outra coordenadora vivenciou uma experiência positiva em relação ao diretor e à equipe técnica, no momento que ascendeu ao cargo, facilitando a sua adaptação e o seu trabalho. Tais depoimentos somam-se à ideia de uma formação contínua articulada 
coletivamente, corolário do envolvimento de toda equipe técnica da escola. Orsolon (2005, p. 21) traz elementos para pensarmos a importância dessa integração:

\begin{abstract}
As práticas administrativas e pedagógicas desenvolvidas na escola desenham as relações e as interações que as pessoas estabelecem em seu interior e definem formas/modelos para o fazer docente. Quando os professores percebem movimentos de organização/gestão escolar direcionados para a mudança de determinado aspecto de sua prática, essa situação pode se constituir num fator sensibilizador para sua mudança. A promoção de um trabalho pedagógico que ultrapasse as fronteiras do conhecimento e das funções/ações rigidamente estabelecidas no âmbito da organização e da gestão da escola, por meio de uma gestão participativa, na qual os profissionais dos diferentes setores possam efetivamente participar da construção do projeto político-pedagógico da escola, colaborando na discussão a partir de seu olhar e de sua experiência, propiciaria a construção de uma escola em que as relações e os planejamentos de trabalho se dessem de maneira menos compartimentada, mais compartilhada e integrada.
\end{abstract}

Segundo Libâneo (2003, p. 87), o “[...] diretor de escola é responsável pelo funcionamento administrativo e pedagógico da escola, portanto, necessita de conhecimentos tanto administrativos quanto pedagógicos". Um diretor com tais conhecimentos é capaz de acentuar a importância do coordenador, sem que isso signifique a diminuição do seu papel de liderança.

Os depoimentos das coordenadoras indicam que, dependendo das relações institucionais e da postura diretiva do administrador, pode existir uma comunhão de projetos que apóia o trabalho do coordenador pedagógico na escola, em função dos resultados esperados, ou seja, a melhoria dos processos de ensino-aprendizagem. Mas existem diretores que não abrem mão de sua 'autoridade' e concentram todo o trabalho em suas mãos, executando-os de acordo com suas próprias percepções e concepções de educação, colocando em risco o sucesso dos projetos de natureza pedagógica. Sem contar que uma equipe dividida não realiza um trabalho eficiente, não produz as mudanças necessárias ou pretendidas.

A falta de apoio do diretor em relação ao trabalho do coordenador cria um mal-estar na escola que dificilmente poderá redundar em projetos que envolvam toda a comunidade educativa.

Tal como é próprio da lógica do trabalho coletivo e de uma gestão participativa, a liderança do diretor pode gerar uma organização favorável para o desenvolvimento pedagógico, na medida em que abre possibilidades para que cada profissional manifeste seus saberes num projeto de trabalho partilhado. As falas das coordenadoras são profícuas em apresentar, de forma incisiva, a necessidade dessa relação respeitosa. Nelas vemos que as 
práticas da coordenação pedagógica ficam obscurecidas ou perdem o foco quando não existem harmonia e respeito entre diretor e coordenador pedagógico. Silva Junior (1993, p. 77), ao se referir ao papel do administrador escolar, afirma:

Trata-se de alguém que dirige o esforço coletivo dos professores, orientandoo para o fim comum, ou seja, o domínio do saber escolar de seus alunos. $O$ administrador é assim alguém a serviço do serviço que os professores prestam a seus alunos. (grifo do autor)

Como salienta o autor, o administrador trabalha em função da atividade docente, também o coordenador labuta em função da ação docente junto aos alunos, visando à aprendizagem. O papel do coordenador não é controlar o ofício do professor, pois é este quem planeja e faz a mediação, na prática, entre o ensino e a aprendizagem. É um trabalho voltado para o acompanhamento e assistência pedagógico-didática dos professores, que, na formação, significa criar com os professores instrumentos de reflexão e investigação sobre a prática pedagógica, para que possam conceber, organizar e desenvolver situações adequadas à aprendizagem dos alunos.

\subsection{O supervisor, um vértice do triângulo da equipe pedagógica}

A figura do supervisor na educação pública nacional não é nova. Saviani (2003) localiza a função supervisora no início da colonização do país, especificamente na ação dos 'prefeitos de estudos', figura ligada ao ensino dos jesuítas, cuja função, naquele tempo, estava pautada por regras que faziam dessa personagem o controlador da política de ensino determinado pela 'Companhia de Jesus'.

Desde então, a função delegada aos 'supervisores ${ }^{61}$, está cada vez mais associada à atividade de inspeção do trabalho escolar, inspirada em pressupostos técnico-burocráticos, cuja explicação está representada na idéia de que a melhoria da qualidade de ensino só é possível mediante o controle sob a escola. Porém, pode assumir na perspectiva de uma nova referência de ação supervisora um papel de assessoramento que permita à escola investigar sua ação, desenvolvendo os processos formativos. No dizer de Franco (2007, p.194 ):

Os Supervisores de Ensino, assim como os profissionais da escola entendem que a ação Supervisora precisa estar vinculada estreitamente com os

$61 \quad$ No decorrer da história da educação brasileira, a figura responsável pela função de supervisão das escolas recebeu várias denominações. Para aprofundar os conhecimentos sobre a supervisão escolar, consultar Franco (2007). 
interesses e necessidades do desenvolvimento institucional da escola. Contudo a condição de função de sistema e de Estado lhes confere uma forma de poder de intervenção que precisa estar pautado em princípios democráticos de inferência e reconhecimento do papel dos profissionais da escola.

O supervisor, a partir dessa análise, pode intervir nas escolas de, pelo menos, duas formas: uma, no trabalho pedagógico, numa supervisão que possibilita à equipe escolar facilitar o desenvolvimento da autonomia crítica, propondo saídas pedagógicas ou formativas para as dificuldades encontradas. Outra, numa supervisão pautada nas solicitações burocráticas, na homogeneização dos processos formativos e no controle.

Sem uma reflexão crítica, o supervisor pode assumir a atribuição de repassar as determinações da Diretoria de Orientação Técnica (DOT) da SME para as escolas e os coordenadores podem escolher atuar dessa mesma forma junto aos professores. São 'gestores' que não interagem e não discutem a realidade objetiva, portanto não gerenciam em conjunto, diretor, supervisor e coordenador.

As coordenadoras manifestaram diferentes percepções e experiências em relação à atuação do supervisor na escola. A maioria aponta que o foco delas está nas questões burocráticas, nas orientações legais, e não no acompanhamento da escola, dos seus sucessos e das suas dificuldades:

O interessante é que nunca nenhum supervisor chegou até nós para comentar, conversar sobre o projeto ou perguntar como ele está sendo desenvolvido. A única vez que houve uma conversa pedagógica foi na época do GAAE, que era o Grupo de Acompanhamento da Ação Educativa. Então, uma consideração feita por esse grupo era que a escola chegasse a um consenso sobre o que consideraria dificuldade de leitura e escrita. Era preciso definir dentro de que concepção essa dificuldade seria trabalhada. Acho que foi o único momentos que o projeto foi questionado, digo, que foi feita uma abordagem pedagógica. Em outros momentos as intervenções do supervisor foram no sentido de alterar algo de natureza burocrática, como: modificar a data, acrescentar uma hora que faltou. (COORD. MARIA VITÓRIA)

Eu fico pensando [...] que aquele que está mais próximo (o supervisor) pode vir e discutir um pouco com a escola. Não para colocar defeito, mas para tentar aproximar-se e entender. [...]. Nós sentiríamos o apoio, seria mais uma pessoa com quem conversar, com quem dividir as questões. Eu acho que seria uma pessoa a mais nesse âmbito. É lógico que, dadas as características da função do supervisor - ter muitas escolas, fazer averiguações -, não dá para ter um acompanhamento direto, isso é óbvio. Mas é possível parcerias. (COORD. MARIA STELLA) 
Quando iniciei na coordenação, não tinha experiência no ensino fundamental. Foram muito assustadores esses seis meses iniciais. $\mathrm{O}$ supervisor responsável pela escola não tinha o entendimento de que eu precisava de apoio, de alguém para ajudar a direcionar o trabalho, porque não conhecia esse trabalho [...]. O supervisor cobrava muita coisa burocrática, tinha que entregar muitos documentos, o diário de classe, as avaliações das crianças, o relatório do Conselho de Classe. Eu tinha muitas dificuldades e demorava muito, porque não tinha nem afinidade, nem entrosamento com aquilo. (COORD. MARIA LEDA)

Quando a supervisão visita a escola e encontra uma escola que não dá trabalho e não tem pais reclamando, consegue ver seriedade, a prática que desenvolvemos registrada, transformada em cadernos e livros que estão lá na sala de leitura, há muita visibilidade no trabalho, então, não precisa controlar a escola porque a escola é séria. A escola é ousada, inventa coisas, faz tudo para melhorar a sua qualidade. (COORD. MARIA AUGUSTA)

As falas das coordenadoras expressam a distância existente entre o desejo de um supervisor que deveria ser parceiro dos coordenadores no desenvolvimento da formação na escola e o papel real que consiste em assumir uma postura técnica de quem está de fora, não colabora, mas pune o fracasso. As entrevistas revelam um supervisor pouco crítico, mais preocupado com a forma do que com o conteúdo dos projetos; distante da escola, com cujo apoio não se pode contar; burocrático, mais preocupado com os papéis do que com as pessoas; controlador, caso a escola tenha problemas, e dispensável, caso a escola se articule sozinha.

A coordenadora Maria Augusta aponta para o foco da autonomia relativa da escola, o projeto político pedagógico. Para ela, uma escola que trata seus projetos com seriedade, que dá visibilidade ao trabalho realizado, não sofre com o controle externo da supervisão.

No entanto, para boa parte dos coordenadores, a ação supervisora tem como característica o controle. O trabalho desse profissional, assim, se desenvolve no sentido de que o PEA siga as determinações das portarias. Essa ação parece estar pautada no investimento feito na formação do coordenador pedagógico por meio do curso "A rede em rede, a formação continuada na Educação Infantil ${ }^{62 ",}$, destinados aos coordenadores de educação infantil, e o programa "Ler e Escrever: Prioridade na Escola Municipal" que contempla os projetos “Toda Força ao primeiro ano (TOF), Projeto Intensivo no Ciclo I

\footnotetext{
${ }^{62}$ O programa de formação do coordenador pedagógico na educação infantil foi sistematizado através de três produções SÃO PAULO (SP) SME. DOT. São Paulo é uma escola - Manual de Brincadeiras. SME/SP/DOT, 2006; SÃO PAULO (SP) SME. DOT. Tempos e espaços para a infância e suas linguagens nos CEIs, creches e EMEIs da cidade de São Paulo. SME/SP/DOT, 2006; SÃO PAULO (SP) SME. DOT. A Rede em rede a Formação Continuada na Educação Infantil. SME/SP/DOT, 2007.

63 O programa "Ler e Escrever - Prioridade na Escola Municipal" orienta a formação do coordenador pedagógico no ensino fundamental e as ações dos professores participantes dos projetos.
} 
(PIC) e Ler e escrever em todas as áreas do ciclo II", destinados aos coordenadores do ensino fundamental. Esses programas e projetos visam à implantação das políticas públicas de educação pela via da formação no horário coletivo, do qual o coordenador pedagógico é o principal articulador.

Segundo os depoimentos, é possível inferir que o acompanhamento feito pelo sistema, por meio do supervisor, oferece pouco apoio às reflexões oriundas do trabalho desenvolvido pela escola, está mais pautado no controle e na observação das atividades desenvolvidas. O risco de ações pautadas apenas por procedimentos técnicos é não considerar:

-As peculiaridades locais importantes para a implantação bem-sucedida de projetos educativos;

- A relativa autonomia da escola, pautada num conhecimento coletivo e local;

- A responsabilidade dos educadores na sua comunidade;

- A diversidade da formação dos sujeitos responsáveis pelo trabalho com os conhecimentos;

- Os coordenadores, suas dificuldades e saberes;

- A falta de preparo (formação) dos próprios supervisores, que, por não poderem trazer grandes contribuições às reflexões desenvolvidas em cada escola, acabam, apenas, fazendo uma inspeção pouco crítica;

-A forma diversa com vem se constituindo o trabalho da coordenação pedagógica nos diferentes espaços educativos.

Segundo Souza (2005, p. 170):

O supervisor pode trabalhar com o olhar para o pedagógico, numa postura crítica, reflexiva junto à equipe escolar e aos professores, utilizando-se do administrativo a favor do pedagógico, negando o caráter meramente burocrático, impositivo, normativo e controlador. O trabalho do supervisor escolar estaria voltado a um projeto coletivo, em que a colaboração, a confiança, o pensar, o fazer junto pode propiciar o desenvolvimento profissional de todos, com uma formação de melhor qualidade.

O que se espera, da parte dos supervisores, é um tratamento diferenciado em cada escola, ora ajudando quem tem mais dificuldades, ora apoiando quem consegue fazer um trabalho eficiente de forma autônoma. 
Um trabalho genérico fere a ideia de um grupo de pessoas que partilham a organização da escola em favor de um projeto comum. Normalmente, essa situação se configura devido à ausência de diálogo pela hierarquização das funções, em que o supervisor é o elo mais forte, e pelas 'orientações' do sistema de ensino que delimitam o percurso formativo a ser seguido, influindo na organização dos projetos de formação e na articulação pelo coordenador pedagógico, quer pela pressão pela implementação de programas externos, quer pela adaptação das determinações do sistema aos projetos da escola, quer por assumir os projetos próprios.

Assim, com bases nessas premissas, só é possível entender a ideia da escola como locus de formação contínua do docente, baseada numa concepção de autonomia institucional que tem no seu projeto político pedagógico as diretrizes e metas de sua ação e no reconhecimento da capacidade das equipes (professores, diretores e coordenadores), ainda que assessoradas (pelo supervisor ou outro elemento do sistema), de elaborar, desenvolver e avaliar seus projetos formativos (PEAs), identificando as necessidades da própria prática. Nesse contexto, o coordenador torna-se o responsável por acompanhar de forma sistemática esse processo, especialmente por meio da promoção da reflexão crítica sobre as práticas e pelo favorecimento da investigação sobre a ação pedagógica na escola.

Considerando a especificidade do trabalho do coordenador pedagógico, a seguir este trabalho se propõe a analisar o papel do coordenador pedagógico como gestor da formação centrada na escola, apontando alguns desafios dessa ação. 


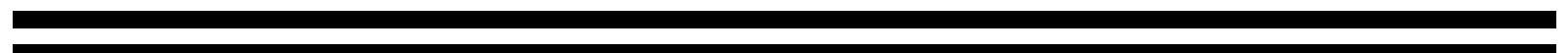




\section{O COORDENADOR PEDAGÓGICO E A FORMAÇÃO DO DOCENTE NA ESCOLA}

O coordenador pedagógico deve concentrar-se nas questões pedagógicas, deve ter predisposição para estudar, precisa exercer a liderança junto ao grupo de professores, não de uma forma impositiva, mas sim na forma de mediação.

Coordenadora Maria Stella 
O coordenador pedagógico, cuja função está localizada na escola, está física, emocional e epistemologicamente ligado aos educadores e aos alunos que coordena. Sendo assim, o que pode significar coordenar o pedagógico? Libâneo (1996, p. 128) traz uma reflexão nesse sentido:

[...]quando se atribui ao pedagogo as tarefas de coordenar e prestar assistência pedagógico-didática ao professor, não se está se supondo que ele deva ter domínio dos conteúdos-métodos de todas as matérias. Sua contribuição vem dos campos do conhecimento implicados no processo educativo-docente, operando uma intersecção entre a teoria pedagógica e os conteúdos-métodos específicos de cada matéria de ensino, entre os conhecimentos pedagógicos e a sala de aula.

Para o autor, a contribuição do trabalho do coordenador da escola está relacionada a uma intervenção no campo dos conhecimentos didático-pedagógicos que mediam a relação entre o ensino e a aprendizagem. A coordenadora Maria Stella, na epígrafe, ressalta as 'questões pedagógicas', ou seja, aquelas relativas ao ensino e à aprendizagem, como tarefa primordial desse profissional, associando-a a um processo de formação contínua articulado pelo coordenador e mediado pelo exercício da liderança.

A preocupação com o desenvolvimento escolar dos alunos, normalmente ligada à organização curricular e à revisão ou análise da postura didático-pedagógica tem, de modo geral, se refletido na organização da formação posta ao docente. E é assim que, direta ou indiretamente, tem se encaminhado a proposta de formação centrada na escola.

Existe uma percepção distorcida de que tudo na escola é pedagógico. De fato, os trabalhos devem estar imbricados, um ajudando a compor o outro, de modo que o processo educativo extrapole a sala de aula e o currículo seja vivo nas ações de professores, coordenadores, diretores, agentes escolares, alunos e comunidade. Contudo, quando algum aspecto do processo educativo é amplamente generalizado, perde-se o olhar específico e deixa-se de fazer escolhas que indicam as prioridades dos trabalhos desenvolvidos.

Tudo pode ser pedagógico quando o aluno e o conhecimento tornam-se o centro das reflexões e das ações do coordenador. Nessa perspectiva, cabe à coordenação pedagógica 'coordenar' as atividades de modo a promover uma consciência de si e do outro, ligados por um projeto coletivo que estabelece objetivos e metas comuns. Essa articulação crítica entre os professores (seus fazeres e saberes), seus contextos (culturais e sociais) e entre teoria e prática constitui-se, como já ressaltado, em uma parte importante da atuação pedagógica, que tem como meta a legitimação de um ensino de qualidade. 
A formação do docente na escola, que é uma atividade sócio-histórica, organiza os processos de reflexão sobre o trabalho pedagógico, confrontando as teorias pedagógicas com os conteúdos-métodos das áreas de ensino (LIBÂNEO, 2003).

Garcia (2007, pp. 56, 57), ao referir-se à função da coordenação pedagógica em relação ao projeto de formação desenvolvido pela escola, faz a seguinte reflexão:

[...] mais do que o entendimento de que o papel da coordenadora pedagógica é o de tomar conta e controlar o que os professores e professoras devem fazer para ensinar, a ação da coordenação está mais preocupada em garantir e desenvolver o compromisso e a competência, segurança e autonomia do grupo de docentes no cotidiano da ação educacional. [...].É um jeito de realizar a coordenação pedagógica que, na medida em que se preocupa com o bem estar e a segurança do professor ou professora no seu papel de educador, está igualmente preocupada com a construção de sua competência para ensinar e promover a aprendizagem de seus alunos, está preocupada em garantir aos professores e professoras um espaço de formação onde possa expor suas dificuldades e questionamentos, um espaço onde possa começar a ter acesso a uma teoria que se mostra necessária para o seu aperfeiçoamento e avanço profissional e para o fortalecimento de sua dignidade profissional.

Essa idéia, também, está presente no depoimento da coordenadora Maria Vitória, quando questionada sobre o papel do coordenador na constituição da equipe escolar:

Eu acho que o coordenador pedagógico tem que estar preocupado com a constituição do grupo em que ele vai trabalhar. Aqui na escola foi muito interessante. No meu terceiro ano de trabalho, em fevereiro, nos dias de planejamento, os professores estavam superanimados, felizes. Um colega falou que sabia 'qual era a minha'. Antes, segundo ele, os coordenadores pedagógicos da escola falavam: - façam isso ou aquilo - e as professoras não gostavam, ficavam todas tristes. Mas eu não fazia assim e estavam todas animadas. Ele fez-me refletir muito sobre isso, algo que eu fazia intuitivamente. Depois desta conversa, comecei a pensar que esta deve ser uma das preocupações do coordenador pedagógico, ou seja, constituir o grupo com o qual ele vai trabalhar. Porque eu não posso mandar nas pessoas, elas têm que sentir vontade de fazer as coisas, então tenho que ter este trabalho com os professores, tenho que oportunizar situações, materiais, ideias, sugestões, dando apoio nas dificuldades, porque isso vai mexendo com o desejo.

Coordenar o pedagógico pressupõe um profissional afinado com suas atribuições, com capacidade de refletir criticamente sobre o seu fazer, envolvido em desvelar na formação docente as relações existentes entre a teoria e a prática. É perceber a fragmentação com que o trabalho educativo vem sendo executado e criar condições para uma reflexão planejada, qualificada e organizada a partir das necessidades dos educadores envolvidos. 
Como relatou a coordenadora Maria Vitória, coordenar o pedagógico significa pensar na constituição do grupo, não apenas por meio das afinidades pessoais, mas pela composição de afinidades pedagógicas, construídas numa percepção de que os educadores têm conhecimentos e podem transformar suas concepções e práticas.

O pedagógico, assim, é organizado numa dimensão coletiva e se estrutura num projeto político, que toma forma nas ações elaboradas reflexivamente, no processo de elaboração de sentidos e de negociações de ideias e ações. O grupo escola personifica o 'ideal' pedagógico quando constrói coletivamente os caminhos a serem percorridos e seus profissionais passam a organizar projetos de ações factíveis, que identificam a escola e seus autores.

A proposta de formação centrada na escola, quando há um investimento no coletivo escolar, valoriza os saberes e experiências dos educadores e propõe a reflexão sobre a prática, estabelecendo um diálogo entre ela e o conhecimento pedagógico existente.

Os projetos de formação desenvolvidos na escola aproximam-se da concepção de que professores, coordenadores pedagógicos, diretores e outros membros da comunidade escolar constituem-se em sujeitos de sua ação e de seu desenvolvimento profissional.

\section{O coordenador pedagógico como gestor da formação}

A transferência do locus de formação docente tem propiciado nos meios acadêmicos uma reflexão sobre as condições de produção da formação na escola, considerando o espaço, o tempo, os recursos necessários, o ‘formador' e, especialmente, a valorização dos saberes docentes, como uma produção que congrega teoria e prática.

Pensar a formação na escola é reconhecer a importância de tratar de dois elementos básicos que estão imbricados e associados a esta mudança física do espaço formativo. $\mathrm{O}$ primeiro está relacionado à própria mudança de local, de fora para dentro da escola, o que não significa transposição. Não é um curso pensado para ser executado em local diverso da escola que, por motivos de organização (ou falta de organização), passa a ser oportunizado dentro dela. Não é apenas mudar de um lugar para outro mantendo-se a mesma estrutura formativa. Implica uma reformulação na compreensão dos papéis formativos e uma valorização dos conhecimentos dos educadores envolvidos naquele espaço/tempo. 
Um segundo elemento diz respeito ao protagonismo de professores e coordenadores na tomada de decisões relativas ao seu próprio desenvolvimento profissional. Ao aproximar a formação do local de trabalho, encurta-se a distância entre a ação docente real e a reflexão sobre essa ação. Isso implica tomar as necessidades da prática como elemento de reflexão para a formação, o que significa que ela se desenvolverá para responder às 'ansiedades' formativas de um determinado grupo de educadores comprometidos com o trabalho pedagógico num tempo/espaço determinado. Conforme aponta Nóvoa (2002, p. 40):

\begin{abstract}
A formação contínua alicerça-se na dinamização de projectos de investigação-ação nas escolas, passa pela consolidação de redes de trabalho colectivo e de partilha entre os diversos actores educativos, investindo as escolas como lugares de formação. A formação contínua deve estar finalizada nos "problemas a resolver", e menos em "conteúdos a transmitir", o que sugere a adopção de estratégias de formação-aç̧ão organizacional. (grifo do autor)
\end{abstract}

Nesta perspectiva, é preciso considerar como são 'significados/entendidos' os professores no processo formativo e observar como os coordenadores pedagógicos são 'interpretados' pelo coletivo docente com o qual trabalha e pelo sistema de ensino, pois tais aspectos podem ser determinantes do modelo de formação desenvolvido.

Marcelo Garcia (1999), ao refletir sobre o desenvolvimento profissional docente, destaca a formação centrada na escola como uma modalidade assumida por investigadores, formadores e, também, pela Administração Educativa. Para o autor, essa formação apresenta três condições que se autoinfluenciam: a liderança, como elemento motor, o clima organizacional, que são as relações estabelecidas entre os profissionais, e a natureza do desenvolvimento profissional, ou seja, seu caráter reflexivo, a relação com o contexto, a participação dos envolvidos etc.

Esses aspectos, conforme identificado na pesquisa, têm uma conexão com as dimensões da prática formativa na realidade paulistana. O coordenador pedagógico representa a figura de liderança; o clima organizacional está relacionado à existência ou à ausência de um trabalho coletivo e cooperativo; e a natureza do desenvolvimento profissional está associada a aspectos práticos e conceituais, ou seja, o menor ou maior grau de autonomia na elaboração do projeto formativo, o caráter reflexivo de tais propostas, a participação dos professores na sua elaboração etc.

Os depoimentos das coordenadoras revelam uma intrincada percepção sobre a formação dos professores na escola que refletem as ideias de Marcelo Garcia (1999), pois ao 
posicionaram-se como uma 'liderança' que organiza, desenvolve, acompanha e intervém no processo de formação, revelam sua influência no direcionamento dessa tarefa. As falas que seguem são emblemáticas desse processo:

Eu acho que o coordenador, por desenvolver um trabalho coletivo junto com professores, e este ocorrer em encontros onde as pessoas podem colocar-se, dificilmente sai-se desses encontros como se entrou, principalmente, nos dias de trabalho coletivo. (COORD. MARIA VITÓRIA)

Eu e a outra coordenadora conseguimos sempre estar conversando e procurando discutir alguns caminhos, algumas linhas mais gerais. Esse é um ponto importante enquanto equipe, o grupo perceber que há uma fala única, um conjunto, e que nós nos comunicamos, conversamos e procuramos seguir uma determinada direção. (COORD. MARIA STELLA)

Eu acho que o coordenador tem um papel fundamental. Somos nós que vamos intervindo para que eles [aqueles que não têm compromisso com a profissão] não sejam maioria. Por isso que é sofrido e estamos sempre expostos às agressões, mas, esta briga quem tem que comprar é o coordenador. Eu acredito que não podemos deixar de fazer as coisas por conta dos que não querem. Temos que apostar em quem faz. (COORD. MARIA AUGUSTA)

Esses relatos trazem algumas coincidências no modo de caracterizar a profissão. Todas colocaram o coordenador como centro da articulação da dimensão pedagógica da escola. Isso significa que, quando questionadas sobre o que caracteriza o trabalho de formação na escola, pelo menos na Rede Municipal de Ensino de São Paulo, as entrevistadas apontaram como elementos importantes: o acompanhamento (a presença) do coordenador pedagógico "junto com professores" (COORD. MARIA VITÓRIA); o coordenador como articulador, "discutindo, conversando, seguindo juntos" (COORD. MARIA STELLA) e "intervindo" (COORD. MARIA AUGUSTA). Tais expressões em destaque identificam o papel de liderança do coordenador na condução da formação centrada na escola, cuja ação é pautada no conhecimento e na proximidade com os educadores. Um profissional que coordena, estando junto aos professores, o projeto elaborado coletivamente.

O segundo ponto refere-se ao 'clima organizacional', ou seja, à constituição do horário coletivo como instrumento que propicia mudanças no saber e no saber-fazer docente. Isso fica claro nos destaques: "Ninguém sai como entrou", diz a coordenadora Maria Vitória, "nós nos comunicamos, conversamos e procuramos seguir uma determinada direção", afirma a coordenadora Maria Stella. "Quando eu cheguei aqui [...], uma professora me disse que na sala dela ninguém entrava. É inacreditável, hoje, a transformação dessa professora, ela é 
excelente", completa a coordenadora Maria Augusta. Os encontros na JEIF tornam-se espaços que, se bem articulados ao projeto de formação aderido, promovem mudanças pessoais, de orientação conceitual e na prática docente, principalmente, quando considera as relações interpessoais estabelecidas.

Um terceiro ponto a ser destacado, ainda associado a formação, é a 'natureza do desenvolvimento profissional' que tem como característica uma certa tensão que aparece vinculada a quatro eixos: 1- ao envolvimento dos participantes; 2- à natureza colaborativa da formação; 3- à reflexão sobre a prática; 4- à proximidade do formador 'coordenador pedagógico'. Esses aspectos isolados ou em conjunto determinam em maior ou menor grau a qualidade da formação oferecida.

Em outros espaços formativos, o formador não acompanha diretamente os cursistas, esses, por sua vez, parecem ter a liberdade de, voltando ao seu local de trabalho, reorganizar o que foi tratado no curso, desprezar parte deste material ou mesmo todo ele e, assim, o discurso e a prática podem apresentar certos desníveis. A formação na escola aproxima os diversos profissionais e possibilita a investigação sobre a prática pedagógica in loco, o que pode favorecer a ausência de descompasso entre a teoria e a prática, comuns no discurso docente em relação aos cursos visitados.

Se por um lado, o projeto de formação na escola pode representar as decisões coletivas da unidade educativa, por outro pode conformar-se com as determinações externas. Essa tensão foi observada na Escola A, onde os professores participavam das atividades propostas, mas enxergavam-nas como limitadoras das práticas já existentes na escola. Essa insatisfação não produziu mudanças significativas porque o grupo não estava coeso. Alguns queriam um projeto elaborado pela escola, mas outros não viam necessidade de mudar, pois entendiam que as dificuldades apontadas por eles estavam contempladas no projeto organizado pela secretaria de educação.

A tensão mencionada aparece nos depoimentos das coordenadoras "[...] esse é um ponto importante [...] o grupo perceber que há uma fala única” (COORD. MARIA STELLA), “[...] somos nós que vamos intervindo [...] por isso que é sofrido, e estamos sempre expostos às agressões, mas esta briga quem tem que comprar é o coordenador". (COORD. MARIA AUGUSTA). Estas falas estão associadas à formação proposta no espaço coletivo e à atitude dos participantes. Os sentimentos envolvidos podem ser produto de uma percepção pessoal sobre a atividade desenvolvida e os objetivos esperados. O grupo também pode gerar frustração quando decide não participar de uma atividade ou quando seu posicionamento configura-se como um ataque à pessoa do coordenador. Deste ponto de vista, 
parece que a tensão tem a mesma causa - o maior ou menor grau de envolvimento cooperativo dos participantes.

A natureza interativa da formação na escola pressupõe um coordenador (articulador da formação) e um docente (participante do processo formativo) desenvolvendo uma relação respeitosa e profissional que possibilite a reflexão sobre a ação docente. O quadro que segue exibe a complexidade dessa interação que favorece o deslocamento da pauta da ação formativa que ora está sobre as dificuldades pedagógicas, ora sobre os saberes docentes, ora sobre a aprendizagem (ou não) dos alunos objetivando a construção de novos modos de interação com o conhecimento que favoreçam a aprendizagem dos alunos.

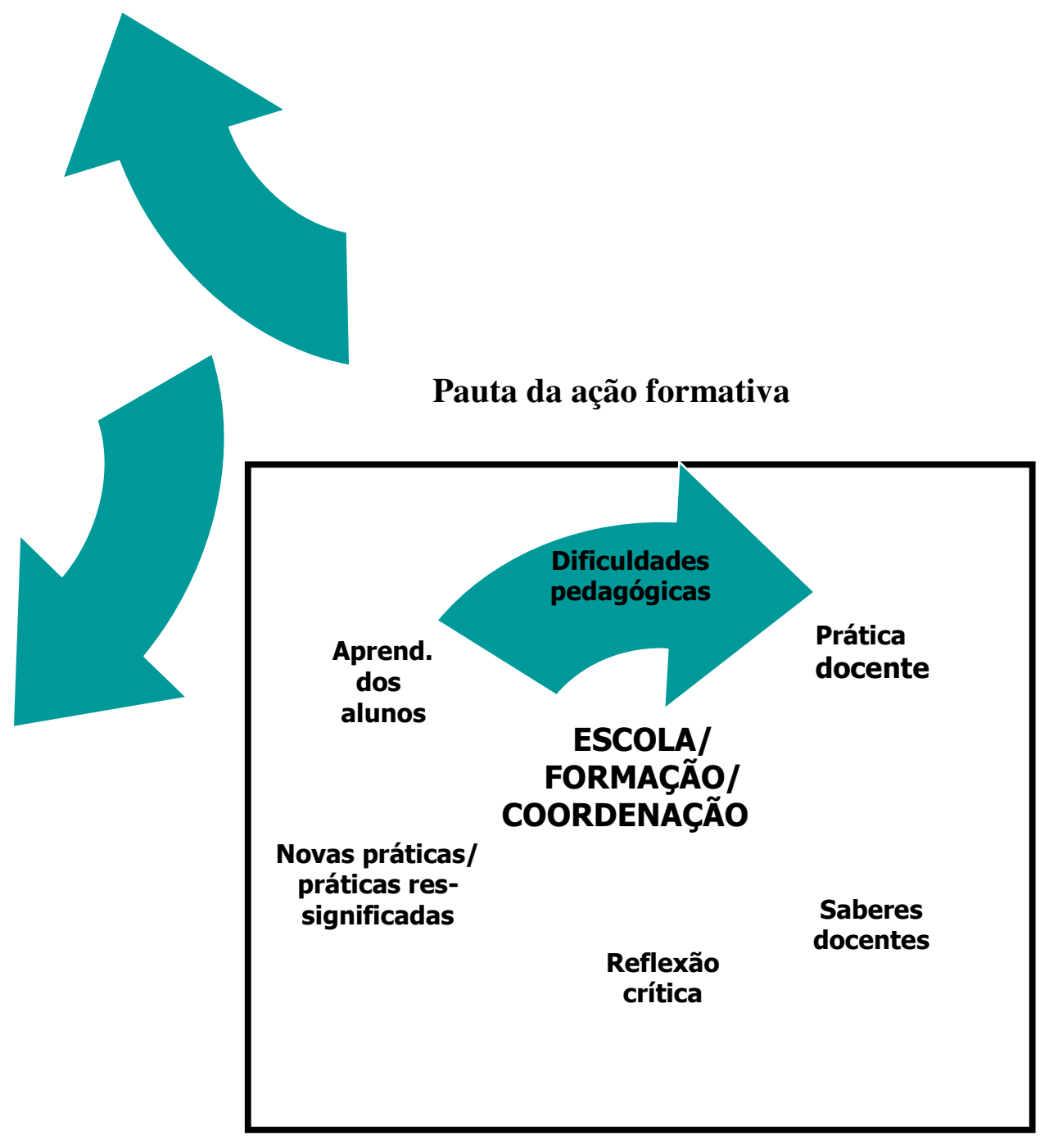

Quadro 11. Elaborado a partir dos dados da pesquisa

A formação na escola aproxima os professores das necessidades pedagógicas, o que torna a prática elemento de análise e reflexão. Isso requer um compromisso com a 
socialização profissional, entendendo-a como parte da formação associada a uma troca 'crítica'de experiências. Foi observado que desvelar as práticas pedagógicas ao grupo não é uma tarefa fácil, assim como é difícil para o grupo a análise do trabalho de um colega.

Marcelo Garcia (1999, p.199), referindo-se à autonomia dos professores no estabelecimento das suas prioridades formativas, salienta a " [...] necessidade de ser entendido como um processo colaborativo, no qual a maioria dos professores se implique, e que esteja baseado nos problemas práticos dos próprios docentes". Desta forma, identifica-se uma ação ativa dos educadores (professores, coordenadores e diretores) não só socialização das prioridades formativas, como também das práticas desenvolvidas. O quadro acima ilustra bem a relação entre a formação na escola e o papel articulador do coordenador que tem na prática docente as referências das necessidades formativas, realçadas pelas dificuldades detectadas, tornando-se o mote da reflexão proposta, da busca de alternativas, da troca de experiências que, por sua vez, re-elabora os saberes docentes e reorganiza a prática em prol da aprendizagem dos alunos, que determinará a direção dos processos reflexivos.

A escola é um lugar de embates, de jogos de poder, tensões e de contradições, que interferem nos projetos e nas relações interpessoais estabelecidas. Pensar o espaço formativo é considerar essas e outras questões que podem comprometê-lo de alguma forma.

Nesse contexto, o coordenador pode ser compreendido como um elo entre os docentes e as determinações das políticas públicas, ou como um articulador das decisões coletivas visando ao pleno desenvolvimento da atividade pedagógica, em prol da aprendizagem dos alunos e do aprimoramento dos professores e, ainda assim, sua ação poderá produzir aproximação ou afastamento, atenção ou resistência, pautadas na compreensão subjetiva do papel deste profissional. Contudo, se os coordenadores não considerarem os saberes docentes, ou mesmo se não ouvi-los no processo de formação, as manifestações podem tornar-se ainda mais difíceis.

O modo de agir do coordenador na condução do projeto formativo pode despertar um maior ou menor envolvimento dos participantes. Se o coordenador colocar-se apenas como um controlador e não como um articulador, tenderá a criar um clima desfavorável ao debate e à reflexão, em que os profissionais dirão aquilo que consideram que o coordenador quer ouvir, mas ainda assim farão o que acreditam. A coordenadora Maria Augusta, referindo-se a esse fato, declara:

Eu acho que a cobrança, o controle é muito ilusório, porque na verdade o professor faz aquilo em que acredita, ou o que ele quer. Uma coisa eu 
aprendi, o que é muito forte na escola pública é a questão da dissimulação. Então, quando se está numa discussão no horário coletivo, tem-se a impressão da adesão, mas aquilo não vai para a prática. A arte da dissimulação é muito forte. Não posso estar me iludindo de que o que foi discutido vai acontecer para todo mundo. Não acontece. Com alguns acontece e é surpreendente, mas os mais resistentes representam um papel de não adesão muito mais forte. Então essa coisa da transparência, da sinceridade, do confronto, da discussão, o coordenador tem que liderar.

O relato não trata de uma desistência do coordenador em relação às dificuldades, mas de um enfrentamento das questões que impedem o desenvolvimento profissional docente. A coordenadora aponta claramente que a formação promove a reflexão dos professores, mas que existem resistências e dissimulações. No primeiro caso, as resistências podem ser saudáveis, pois mobilizam a coordenação a pensar sobre a articulação do projeto coletivo. No segundo, a dissimulação não promove a mudança e nem a reflexão, só a confusão e o desentendimento, dificultando o diálogo, já que o dissimulado não se manifesta de forma clara, objetiva e direta.

Bruno (2005) destaca que dificuldades como essas, envolvendo o coletivo escolar sob a responsabilidade do coordenador pedagógico, requer do grupo o exercício de explicitar suas expectativas e um desprendimento do próprio desejo, que, quando publicado, passa a ser o de outros e pode assim ser modificado.

Uma das dificuldades do trabalho coletivo está no confronto de expectativas e desejos dos sujeitos envolvidos. Dificuldade que precisa de condições especiais para ser superada. [...] O exercício de confrontar as expectativas de cada um dos organizadores do projeto coletivo da escola exige a compreensão de que a explicitação do que se espera implica a publicação de um desejo, de um princípio, de uma convicção. [...] A publicação traz em si a idéia de que algo que era de uma pessoa agora é também de muitos e poderá ser transformada. (BRUNO, 2005, p. 14)

O coordenador que chega à escola assume a difícil tarefa de conquistar seu espaço junto ao coletivo, o que implica passar por experiências de correlações de força (em relação à direção, ao sistema, aos professores etc.), e que poderão interferir na construção de sua identidade profissional, na elaboração e no desenvolvimento coletivo do projeto formativo da escola. Assim as coordenadoras narram seus processos de conquistas de espaço:

Encontramos resistências [referindo-se a um projeto], mas caminhou e foi muito bom, deu visibilidade aos trabalhos dos professores, mesmo quem tinha séria resistência, reclamava e não queria fazer a atividade com aluno, acabou realizando-a. (COORD. MARIA VITÓRIA - destaque nosso) 
As relações são difíceis, para um está bom, para outro não está. É preciso conhecer e considerar em que nível cada um está, como cada um faz a sua organização e como a formação transparece no trabalho com as crianças. Então, uma das coisas que dificulta a formação é esta questão das relações. (COORD. MARIA STELLA)

Eu estranhei muito, porque nunca havia trabalhado com sala ambiente, não sabia como poderia desenvolver o trabalho. Isso e as questões das relações foram o que eu mais estranhei. Eu tinha muitos problemas com relacionamento na outra escola, porque tinha um grupo de professores muito antigo. Eu vim para cá na primeira remoção [transferência de uma escola para outra], estou nessa escola a cerca de três anos. Isso foi muito positivo, o grupo aqui é muito maior do que havia lá, mas é mais receptível, acolhedor, um pessoal que tem vontade de aprender e corre atrás da formação. Na outra escola, todos diziam saber tudo. (COORD. MARIA LEDA - destaque nosso)

O fato dos professores estarem se doando ao trabalho, isso repercute muito bem junto aos alunos. O projeto de ilustração do livro surgiu assim, conheci uma escritora que tinha um texto, mas não tinha ilustração. Falei para ela que se enviasse o livro para a escola as crianças ilustrariam. E virou isso, um livro superbonito com a participação de todos. Quando propus a idéia no início do ano uma professora falou que ia adorar fazer esse trabalho. E depois a convivência nos faz conhecer as pessoas e pensar no que e como propor determinadas atividades. (COORD. MARIA AUGUSTA)

Os depoimentos mostram que o coordenador pode enfrentar resistências por vários motivos: em virtude da chegada de um novo membro na equipe, em relação às crenças e valores dos professores envolvidos, relativas ao tempo na carreira do magistério (professoras mais ou menos experientes) e a heterogeneidade do grupo. Essas situações indicam uma demanda de trabalho e de considerações que deverão ser alvo de reflexão desse profissional antes de propor as discussões sobre as atividades formativas. É impossível agradar a todos, mas é possível ser respeitado pelo trabalho que se faz.

Ademais, a compreensão qualificada e contextualizada da ação gestora do espaço de formação na escola possibilita, primeiramente, o desvelamento das teorias que fundamentam as práticas formativas nesse espaço e, também, permite a introdução de elementos que subsidiem a reflexão desses profissionais, para que lidem criticamente com a imposição de uma sujeição dos papéis, quer pelo controle de alguém ou de algo (uma ideia), quer pela cadeia produzida pela própria história identitária, nessa dinâmica de forças que se enfrentam e se absorvem e que tornam qualquer posição flexível. Tal situação é perceptível nos depoimentos que seguem:

Nós sempre pensamos - não dá para ficar só na discussão teórica. Se não chegar no aluno não vai ter nenhum sucesso. Então, nós fomos tentando 
convencer. Encontramos resistências, mas o projeto caminhou e foi interessante.No começo da formação, era eu e a minha colega tentando, criando meios. Depois, nós percebemos que eles tinham muito para dar e que não havia necessidade de estarmos sozinhas. Então, organizamos a formação e propusemos dividir as tarefas. Escolhemos um autor, um livro, um tema e cada um foi se responsabilizando por uma parte e combinamos que os professores iam estudar e trazer para o grupo. (COORD. MARIA VITÓRIA; grifo nosso)

Quando começamos, era somente o grupo e a coordenação e nós tentávamos pegar as informações com os professores, as expectativas e as necessidades e construir o projeto junto com eles. Até o ano passado nós fomos seguindo essa linha e aperfeiçoando. Esse ano (2006) veio o 'Programa Ler e escrever', que tem um material mais específico e acabou acrescentando às discussões. Então como veio o material do professor, a gente faz uso desse material também. Nesse sentido, acaba uniformizando um pouco mais as discussões dentro dos grupos, porque temos material de apoio. (COORD. MARIA STELLA - grifo nosso)

A gestão do trabalho educativo, especificamente dos processos de formação pelo coordenador pedagógico, pressupõe assumir a escola como comunidade de ensino e aprendizagem também para o professor, portanto disposta a oferecer oportunidade de contrastes de ideias, de atuação e de sentimento, de modo a promover uma reflexão sobre o significado das diferentes concepções e sobre as opções dos docentes na escola. Não significa amoldar-se ao que é determinado para o espaço escolar, mas promover novas formas de ocupação do espaço formativo por todos que dele fazem uso. Segundo Rogério (2008, p. 179):

Os modos de ser professor não são fixos ou imutáveis e se modificam durante a ação do professor no contexto de trabalho deste. As professoras perceberam, à medida que foram avançando na carreira docente, os impactos do seu desenvolvimento profissional nos seus modos de ensinar. Em suma, ao longo dos anos da carreira, o professor vai se desenvolvendo profissionalmente, vai refletindo sobre seu modo de ser e de estar na profissão e vai criando e modificando sua ação pedagógica.

Considera-se que no tempo presente se desvanecem certezas, que antes estavam polarizadas num único campo, como aquela que atribuía ao aluno a culpa pelo fracasso escolar. Atualmente, a idéia pode pender para um outro extremo, o de culpabilizar o professor e sua formação pelas mazelas da educação. Assim, assume importância o modo como são pensados os projetos de formação, quer na escola, quer nos órgãos centrais da administração pública. 
Refletir sobre a gestão da formação em serviço é oportunizar uma discussão sobre as possibilidades de organização do espaço/tempo formador na escola, decisão que deve envolver a todos os participantes.

O trabalho de gerir o espaço/tempo de formação contínua na escola denota escolhas baseadas em concepções. Não é uma decisão neutra, mas sim a manifestação de adesão ou resistência a algum projeto, quer seja elaborado pelos professores no coletivo escolar, quer determinado pelas políticas públicas.

O trabalho do coordenador pedagógico, localizado na escola, apresenta uma complexidade e uma especificidade que o difere da ação supervisora stricto sensu. Sua ação, principalmente no que se refere à formação do professor, pode assumir características de promoção de um projeto formativo que presa a reflexão sobre o fazer pedagógico, mas pode estar associado a um processo formativo que visa à incorporação de métodos e técnicas de ensino ou ao alcance de metas propostas pelo sistema. Nesse caso, o trabalho pode estar impregnado pela ideia de controle, de supervisão local.

O trabalho do coordenador, em oposição a uma homogeneização das condutas pedagógicas no interior da escola, precisa considerar como desafios: o descompasso entre as instâncias do trabalho do coordenador e os dispositivos formativos, a formação como um processo introdeterminado ${ }^{64}$ e a articulação entre as necessidades da formação, a cultura escolar e as determinações das políticas públicas.

\subsection{Primeiro desafio: o descompasso entre as instâncias do trabalho do coordenador e os dispositivos formativos}

O coordenador assume diversas atribuições na escola que são acrescidas pelas demandas do cotidiano, pela relação com a equipe, pela natureza dos projetos desenvolvidos. Segundo a coordenadora Maria Stella, existe uma organização do trabalho que define o real, o que acontece, e o ideal, a utopia , e, ao mesmo tempo em que impulsiona o trabalho acaba se constituindo num padrão de avaliação pessoal nunca alcançado. Entre o real e o ideal, existe uma ação sendo construída e reconstruída, que vai dando contornos ao trabalho de formação na escola. Diz ela:

64 O termo "introdeterminada" é usado no artigo "Percursos de formação e de trans-formação" escrito por Moita (1992), em que a autora analisa os processos de formação como dinâmicos e complexos por meio dos quais vai se construindo a identidade de uma pessoa (pessoal/profissional) nas interações que se estabelecem e no processo de autocriação gerados por tensões e contradições. 
Nós trabalhamos com o real e o ideal. Se conseguíssemos de fato, dentro da escola, priorizar as questões de formação, ter esses espaços para conversar com os professores e fazer intervenções mais diretas, eu acho que ajudaria bastante o professor a refletir sobre o seu trabalho [...]. Esse é o ideal e nós estamos bastante distante dele. Por exemplo, uma escola como a nossa, que é muito grande, embora tenha duas coordenadoras, ainda é pouco. Temos aproximadamente cento e poucos professores. Nem todos estão em jornada ampliada, logo não temos todos no grupo de JEI, não temos todos os professores participando de projetos e não temos tempo, no dia-a-dia, para estar junto daqueles que não participam. Uma coisa que considero essencial no trabalho da coordenação e que me cobro sempre é separar um tempo para ir à sala de aula, ou pelo menos visitar uma turma de alunos por dia. Não só entrar e sair, mas entrar e conversar com as crianças, com as professoras, olhar o caderno, ajudar numa atividade. Se eu consegui fazer isso, duas ou três vezes no ano foi muito. Esse aspecto seria muito importante para o professor, ver o coordenador não como chefia, mas como parceiro que está procurando ajudar. Apesar de toda loucura das salas superlotadas e todos os problemas decorrentes disso, a coordenadora estaria lá para o trabalho ficar mais suave, mas isso seria o ideal, não é o real.

Uma das demandas apontadas pelas coordenadoras e fartamente ilustrada no depoimento da coordenadora Maria Stella é relativa ao descompasso entre o tempo de trabalho e as atividades a serem desenvolvidas pelo coordenador. Todas indicaram que a formação contínua é a prioridade do trabalho do coordenador e, normalmente, esta atividade ocupa mais da metade do tempo de trabalho. Mas se o horário coletivo tem se configurado institucionalmente como espaço/tempo de formação, ainda assim isto não exclui as outras tarefas do coordenador, como acompanhar as turmas e seus professores, conversar individualmente com os docentes ou mesmo preparar os encontros coletivos selecionando material ou lendo textos. Libâneo (2003, p. 183) relaciona doze atribuições da função da coordenação pedagógica:

1. Responder por todas as atividades pedagógico-didáticas e curriculares da escola e pelo acompanhamento das atividades de sala de aula, visando a níveis satisfatórios de qualidade cognitiva e operativa do processo de ensino aprendizagem.

2. Supervisionar a elaboração de diagnóstico e projetos para a elaboração do projeto pedagógico curricular da escola e outros planos e projetos.

3. Propor para a discussão, junto ao corpo docente, o projeto pedagógicocurricular da unidade escolar.

4. Orientar a organização curricular e o desenvolvimento do currículo, incluindo a assistência direta aos professores na elaboração dos planos de ensino, escolha de livros didáticos, práticas de avaliação da aprendizagem.

5. Prestar assistência pedagógico-didática direta aos professores, acompanhar e supervisionar suas atividades tais como: desenvolvimento do plano de ensino, adequação dos conteúdos, desenvolvimento de competências metodológicas, praticas avaliativas, gestão da classe, orientação de aprendizagem, diagnóstico de aprendizagem etc.. 
6. Coordenar reuniões pedagógicas e entrevistas com professores visando promover inter-relação horizontal e vertical entre disciplinas, estimular a realização de projetos conjuntos entre os professores, diagnosticar problemas de ensino-aprendizagem e adotar medidas pedagógicas preventivas, adequar conteúdos, metodologias e práticas avaliativas.

7. Organizar as turmas de alunos, designar professores para as turmas, elaborar o horário escolar, planejar e coordenar o Conselho de Classe.

8. Propor e coordenar atividades de formação continuada e de desenvolvimento profissional dos professores.

9. Elaborar e executar programas e atividades com pais e comunidade, especialmente de cunho cientifico e cultural.

10. Acompanhar o processo de avaliação da aprendizagem (procedimentos, resultados, formas de superação de problemas etc.).

11. Cuidar da avaliação processual do corpo docente.

12. Acompanhar e avaliar o desenvolvimento do plano pedagógicocurricular e dos planos de ensino e outras formas de avaliação institucional.

Observe que as atividades voltadas para o acompanhamento do professor, destacadas pelo autor: "acompanhamento da sala de aula"; "incluindo assistência direta aos professores"; “[...] acompanhar e supervisionar [...]”; “[...] estimular a realização de projetos conjuntos [...]”; "[...] acompanhar o processo de avaliação da aprendizagem [...]” $e$ "[...] acompanhar e avaliar o desenvolvimento do plano pedagógico curricular [...]" também são destacadas na fala da coordenadora “[...] não temos tempo, no dia a dia, para estar junto [...]”; “[...] uma coisa que eu considero ser essencial no trabalho da coordenação e que me cobro sempre, é separar um tempo para ir a sala de aula [...]”; “[...] para o professor ver o coordenador não como chefia, mas como parceiro que está procurando ajuda [...]". Acompanhar o trabalho do professor, individual e coletivamente, é uma tarefa preciosa na percepção das coordenadoras, para encaminhamentos mais específicos e para que o professor não se sinta só, mas que se favoreça das parcerias articuladas pelo coordenador. Este 'ideal' não é atingido porque o tempo cronológico não é o mesmo das demandas. Alguns coordenadores procuram trazer essa tarefa para o horário de formação, em que a participação dos docentes, com seus relatos e com as atividades das crianças, favorece a intervenção da coordenação.

Um aspecto significativo desta forma de rearranjar o tempo e as atribuições é o de levar o coordenador a utilizar-se do horário coletivo para intervenções mais diretas sobre o trabalho docente, pois conforme ressaltou a coordenadora Maria Leda quando inquirida sobre a formação na escola:

[...] se conseguíssemos de fato, dentro da escola, priorizar as questões de formação, de ter mesmo esses espaços para conversar com os professores e 
fazer intervenções mais diretas, eu acho que ajudaria bastante o professor a refletir sobre o seu trabalho [...].

Maria Leda destaca em seu depoimento um ponto da complexidade da ação do coordenador pedagógico que é o de lidar com a idéia de um trabalho de formação que envolve todos os professores nos horários coletivos, mas não descartar o atendimento individual, em atenção às especificidades das dificuldades de cada profissional, além da necessidade de atingir-se com os processos formativos quem não opta pela participação nos horários coletivos, mas desenvolve a docência direcionada pelo projeto político-pedagógico da escola. A formação não se configura apenas com transmissão, mas como uma 'intervenção mais direta', ou seja, uma aproximação da atividade da docência, um pensar junto sobre o trabalho. Esse é de fato o trabalho de formação na escola, que se destaca pela singularidade das intervenções. Tão séria é essa atividade que segundo Maria Stella:

As pessoas precisam ter a clareza de que a prioridade do coordenador é a formação. Então o CP tem que ter um espaço para estar na formação, mas não é para todo mundo que isso está claro. Às vezes, quando estamos agoniadas, nós sempre conversamos sobre o que é importante, e concluímos que é a formação. A existência do coordenador pedagógico se justifica por isso, pensando em alguém que está ali pela formação.

A coordenação pedagógica vem sendo reconfigurada historicamente pelas demandas políticas e econômicas que ditam as regras no jogo da educação pública. Na década de 2000, o discurso do coordenador pedagógico como responsável pela formação na escola tem se multiplicado e, simultaneamente a esse fenômeno, tem diminuído a oferta de cursos oferecidos pelo sistema na modalidade optativa fora da escola. O que isso significa? Será no futuro a escola o único lugar de formação contínua do docente? Essa questão remete ao final do depoimento da coordenadora Maria Stella, aqui transcrito, que aponta para uma intrínseca relação entre a existência do coordenador pedagógico e o trabalho com a formação do docente na escola. Contudo, parece haver uma supervalorização da formação coletiva em detrimento do atendimento individual, também tarefa do coordenador. Isso acontece de tal modo que a coordenadora acaba duvidando de suas próprias percepções sobre o trabalho. Percebe a necessidade de atender individualmente aos professores, mas a pressão pela formação coletiva faz com que direcione tempo e energia para essa tarefa.

Embora exista um discurso voltado para referendar a ação da coordenação na formação do profissional crítico-reflexivo, o constrangimento por resultados e o pouco investimento no desenvolvimento profissional do coordenador, proposto, por vezes, de forma 
'apostilada' ou pré-determinada, impede que o profissional use os conhecimentos de forma reflexiva e crítica na transformação dos problemas locais.

O fato é que esse modelo de formação não pode constituir-se em uma linha de produção de conhecimento para a ação, configurando-se como uma atividade técnica que não dará ao 'professores participantes' as condições para lidar reflexivamente com todas as demandas desse espaço dinâmico, nem estar descolado das demais atividades desenvolvidas por esse profissional.

No que se refere à formação, o coordenador tem responsabilidade no processo de elaboração desse projeto, desvelando as contradições e os limites de alicerçá-lo no senso comum. Estando elaborado e homologado, caberá a ele acompanhá-lo, garantindo suas etapas e promovendo o debate, a reflexão sobre a prática, a pesquisa e a troca de experiência qualificada. Algumas vezes o coordenador poderá convidar um outro profissional para participar das discussões do grupo, para aprofundar determinado tema ou trazer outras perspectivas. No entanto, ficará sob sua responsabilidade estabelecer a relação com as necessidades formativas do grupo.

Nesse processo, o coordenador pedagógico poderá ter o registro como um aliado para a ampliação da pauta reflexiva, dos avanços construídos, das relações estabelecidas com a prática e, também, promover sua autoformação por meio do estudo de textos, da troca com seu par da mesma escola, ou com outros pares de escolas diversas. Para isso poderá pensar sua própria formação em rede, espaço este que deverá constar do projeto político pedagógico.

A formação na escola pode assumir como características a reprodução pura e simples das pautas elaboradas pelo sistema, pela pressão dos órgãos centrais por resultados, ou pela compreensão de que é a função do coordenador atender às demandas do sistema. Nesse caso, o coordenador torna-se o canal por onde flui as determinações das políticas públicas, que nem sempre respeitam a produção coletiva dos profissionais que exercitam, no espaço de formação na escola, o pensar sobre o seu saber e fazer.

Canário (2006), referindo-se ao órgão de gestão da formação da escola em Portugal, acredita ser sua função criar dispositivos formativos menos preocupados com a transmissão de conhecimentos e mais envolvidos com a resolução de problemas reais.

Os dispositivos permanentes de formação estão relacionados a um planejamento estratégico de longa duração que, por meio de condições institucionais, materiais e do envolvimento de todos, buscam superar a dicotomia entre a teoria e a prática, entre a formação e a ação. 
Assim, tornam-se dispositivos formativos o acompanhamento dos professores pelo coordenador, as visitas externas a museus, teatros e outros, a organização de um trabalho cooperativo entre escolas, o registro das descobertas e as construções docentes, a socialização dos avanços conceituais em resultados comunicáveis aos outros, a valorização das experiências docentes por meio de uma troca reflexiva de informação e outras situações que os coordenadores podem organizar para promover a formação contínua centrada na escola.

\subsection{Segundo desafio: a formação como um processo introdeterminado}

As coordenadoras apontaram nos depoimentos a importância e a necessidade de considerar a formação contínua como um projeto pessoal. Mesmo quando ela é informal, nos corredores e no horário do café, ainda assim é um jogo que pressupõe uma decisão pessoal de envolver-se com outras pessoas.

A formação centrada na escola não foge desse padrão. Também é introdeterminada e, neste caso, em dois sentidos. O primeiro deles está relacionado a uma disposição interna em estar junto com outros, organizando e participando efetivamente desta formação. Isso significa uma re-elaboração interna que se manifesta externamente de forma mais imediata, na opção por uma jornada que possibilite a participação em processos de formação. A escolha acontece, na rede municipal de ensino de São Paulo, antes da elaboração coletiva do PEA e, nesse momento, podem acontecer distorções e descomprometimentos. Caso ocorra dessa forma, essas situações revelarão uma tomada de posição interna e não significa que não possa ser alterada, ou que no processo não haverá nenhum desenvolvimento profissional.

$\mathrm{O}$ segundo sentido, imbricado com o primeiro, está relacionado às transformações subjetivas produzidas pela formação, nas concepções, nas ideias, no saber e no fazer docente resultado de uma assimilação complexa, incapaz de ser medida na totalidade de sua abrangência.

Segundo Moita (1992), esta situação é altamente significativa para os formadores, pois este é um processo complexo em que se entrecruzam várias formações, as antigas, as do tempo presente, as informais, as que acontecem na prática cotidiana, as que envolvem as experiências pessoais de cada formando e outras. Portanto, para que tal situação não escape totalmente do projeto organizado, ele precisa assumir uma característica dialógica: 
Os formadores encontram-se confrontados com a complexidade dos processos de formação que se entrecruzam em cada pessoa, em cada formando. A compreensão desta complexidade, mesmo que feita por aproximações, é uma tarefa que se impõe, de forma algo paradoxal, na medida em que a formação é uma realidade que "escapa" de certa maneira dos formadores, porque é fundamentalmente introdeterminada. (MOITA 1992, p.113)

Não se trata aqui de lutar contra esse fato ou de negá-lo, mas entender que esta é uma variável que atravessa o percurso de formação dos docentes em qualquer espaço, inclusive na escola. Não significa deixar de oferecer este espaço/tempo formativo, mas que o coordenador considere que tal interferência pode refletir numa oposição àquilo que se pretendia. Canário (2006) acrescenta que a formação, mesmo coletiva, é autoformação à medida que é uma processo pessoal de autoconstrução. Portanto, na escola, no horário coletivo acontece a autoformação, e será sempre 'auto' porque é pessoal e intransferível, de professores e coordenadores pedagógicos. Na íntegra, o autor afirma:

A autoformação é frequentemente entendida como uma modalidade em que o formando atua de forma independente e solitária, na ausência física de um formador. $\mathrm{O}$ entendimento que tenho deste conceito corresponde a uma perspectiva bem maior: o de um processo de autoconstrução da pessoa. (CANÁRIO 2006, p. 83)

Esta é uma característica do desenvolvimento profissional em espaços individuais ou coletivos, ou seja, a formação acontece (ou não) no sujeito em formação, num processo de autoconstrução. Tal perspectiva reforça como desejável a participação dos educadores na formulação dos próprios projetos de formação, como um aspecto coletivo que permite ao formador aproximar-se das subjetividades dos sujeitos.

Libâneo (2003) entende que as pessoas investem tempo naquilo que valorizam e que o mesmo princípio se aplica à formação. Quando os professores acreditam ou têm interesse em determinado aspecto da formação, investem tempo e energia naquilo. Então, além da mudança interna que a formação promove, ou melhor, pode promover, existe também uma predisposição que se manifesta externamente, que é a busca pela formação necessária. Para o autor:

Uma coisa é certa: as pessoas arrumam tempo para as coisas que compreendem, que valoram e nas quais acreditam. Os dirigentes da escola precisam, então, ajudar os professores, a partir da reflexão sobre a prática, a examinar suas opiniões atuais e os valores que as sustentam, a colaborar na modificação dessas opiniões e valores tendo como referência as necessidades 
dos alunos e da sociedade e os processos de ensino e aprendizagem. (LIBÂNEO, 2003, p. 29)

Esta idéia de Libâneo é retomada na pesquisa pelos depoimentos das coordenadoras Maria Stella e Maria Leda, que entendem o espaço formativo da JEIF, por suas características de construção coletiva, como um elemento que agrega necessidades e interesses diferentes e que responde pela busca pessoal de cada um dos envolvidos, "o que o professor quer para a formação". Porém, para a coordenadora Maria Leda, esta procura não pode ficar restrita à escola:

Para ter um processo de formação é preciso ter a predisposição das pessoas, às vezes, o grupo não caminha igualmente [...] e nem sempre você tem todo mundo predisposto para estar ali participando. (COORD. MARIA STELLA)

O melhor processo de formação é aquele no qual o professor está envolvido, aquele em que ele corre atrás, que vai a busca. Pode até ser que ele venha buscar no horário coletivo, pois [...] a própria escola na sua organização pode garantir o que o professor deseja para a formação. Quando corremos atrás de formação, é porque sentimos a necessidade; mesmo havendo a formação na escola, acho que o professor deve participar de outras situações de formação, além da escola. (COORD. MARIA LEDA)

As coordenadoras ressignificam elementos identificados pelos autores citados. Elas apresentam como determinante do desenvolvimento profissional uma mobilização interna, "predisposição", "um correr atrás, ir em busca” que não pode limitar-se apenas ao espaço escolar. Num curso, fora da escola, convergem pessoas de interesses comuns, mas de lugares diferentes. Na escola, o desafio para o coordenador/formador é articular a formação, num espaço no qual se agregam ação e reflexão, com pessoas de interesses diversos, mas com um pacto formativo comum, centrado numa escolha coletiva. Canário (2006, p. 74) amplia essa reflexão quando afirma:

A otimização do potencial formador dos contextos de trabalho passa, em termos de formação, pela criação de dispositivos e dinâmicas formadoras que propiciem que as experiências vividas no cotidiano profissional transformem-se em aprendizagens, a partir de um processo de autoformação, marcado pela reflexão e a pesquisa, em níveis individual e coletivo. É esta articulação entre novos modos de organizar o trabalho e novos modos de organizar a formação (centrada no contexto organizacional) que facilita e torna possível a produção simultânea de mudanças individuais e coletivas. Os indivíduos mudam, mudando o próprio contexto em que trabalham. 
Então, dentro deste enfoque, um grupo comprometido vence o desafio de, junto com a coordenação pedagógica e orquestrada por ela, promoverem a gestão do espaço formativo na escola de modo colaborativo. Nesse caso, a formação como elemento introdeterminado, manifesta-se numa participação efetiva que dá 'concretude' para o projeto educativo da escola, por meio de uma relação coerente entre teoria e prática.

\subsection{Terceiro desafio: fazer a articulação entre as necessidades da formação, a cultura escolar e as determinações das políticas públicas}

Cultura escolar e políticas públicas são dois conceitos imbricados. A organização das escolas, da forma como a conhecemos hoje, e as determinações sobre seu funcionamento são, sem dúvida, resultado das decisões políticas que se transformaram em cultura escolar. A escola tem vivido os desmandos e as descontinuidades dessas políticas, que, por seu caráter repetitivo, constituem-se em parte da cultura escolar, no sentido generalíssimo, o que gera um sentimento ora de resistência a mudanças, ora de conformismo em relação a essas intervenções. Segundo Marcelo Garcia (1999, pp.193-195):

[...] os processos de desenvolvimento profissional são claramente determinados pela política educativa de momento, sendo tal política concretizada em relação ao currículo, à organização e ao funcionamento das escolas. Assim, fica claro que é a Administração Educativa quem determina as "propriedades de formação" dos professores para que estes se tornem mais aptos a desenvolver a política educativa planificada a nível oficial. [...] Aquilo que denominamos política educativa inclui também aspectos que se referem aos professores como profissionais: salários, incentivos, autonomia, controlo, rendimento, etc., que influenciam o desenvolvimento profissional, na medida em que podem funcionar como factores motivantes ou alienantes dos professores em relação ao seu compromisso profissional. [...]. Mas os processos de desenvolvimento profissional são também determinados pela cultura organizacional dos centros $[\ldots]$ o tipo de cultura que existe num centro facilita ou dificulta o desenvolvimento dos processos de formação autônomos, de colaboração e de formação centrada na escola.

Assim, como os processos de ensino são determinados pelas políticas públicas, os processos de formação do docente em serviço e na escola são, também, construções dessa política, concretizadas nos encaminhamentos na escola e na vida profissional do docente. Em relação à formação contínua na escola, o horário coletivo de trabalho dentro da jornada dos 
professores, as condições físicas e materiais para a reflexão na escola, dentre outros, são ações decorrentes de políticas públicas assumidas pelo sistema educativo.

É preciso, portanto, analisar as políticas de formação, pois, normalmente, estão centradas na lógica do mercado, que trabalha para desobrigar o Estado de suas responsabilidades de manutenção dos sistemas de ensino, o que pode significar, em relação à formação do docente na escola, a opção por investimentos mínimos nas condições para que a formação no locus de trabalho ocorra.

A cultura escolar, por sua vez, sofre influência da cultura generalista da sociedade, pois a escola, como qualquer instituição social, desenvolve-se num contexto mais amplo, no entanto, produz uma cultura específica (organizacional e do docente), que se traduz nas formas de organização, nos conhecimentos, nos valores, nos significados e nos comportamentos compartilhados pelo grupo que a ela tem acesso, num espaço e num tempo determinados.

Assim, a cultura escolar, por ser um fenômeno complexo e multidimensional, constitui-se por uma intersecção de diversas culturas e com arranjos decorrentes das relações específicas que se manifestam e se estabelecem no interior da escola, inclusive de poder, que, de maneira tenaz, reafirma certos modos de conduta e pensamento. Entendida dessa forma, a cultura escolar apresenta uma relação com as tradições (rituais, rotinas e receitas), construídas no tempo histórico, e as inovações fruto de mudanças múltiplas, na própria escola, no entorno, no mundo, de ordem administrativa ou subjetiva, que também estão relacionadas ao currículo e à forma de organizá-lo. Essa cultura identifica a maioria das instituições 'escola' espalhadas pelo mundo.

Pérez Gómez (2001) considera a cultura como produto simbólico (tecido de significados compartilhados) que é reproduzido, assimilado e recriado pelos indivíduos e pelos grupos e apresenta certo grau de funcionalidade para se desenvolver nas condições sociais e econômicas do meio. Assim, a cultura da escola não é autônoma, ela sofre influência de situações externas, como o meio social em que a escola está alocada, as situações mais globalizadas, as reformas, e, também, de situações internas. Segundo esse autor:

A cultura da escola como instituição e a cultura dos docentes como grêmio profissional são objetos de reconstrução quando os docentes concebem sua prática como um processo de aberta e interminável reflexão e ação compartilhadas. (PÉREZ GÓMES, 2001, p.199) 
Desse ponto de vista, é possível pensar que a formação contínua na escola, desenvolvida nas unidades educativas da Rede Municipal de Ensino de São Paulo, influenciaos e é influenciada, ao mesmo tempo, pelos elementos que compõem a cultura escolar, à medida que problematiza (ou não) determinadas posturas. Nesse aspecto, o coordenador pedagógico, como gestor do processo de formação contínua organizado pela equipe escolar, pode dar sua contribuição por meio dos questionamentos às certezas e às verdades que caracterizam, ainda que provisoriamente, a ação educativa.

A cultura - entendida como significados partilhados, conhecimentos, valores e comportamentos - está normalmente restrita a uma comunidade, a um marco espacial e temporal que tornam plástico o seu conteúdo, o que solicita um coordenador que construa coletivamente o sentido da formação desenvolvida naquele espaço/tempo.

Contudo, algo ainda mais específico, uma cultura própria e localizada construída nos espaços de singularidades, vai se estabelecendo e se modificando, à medida que interage com a cultura das reformas que se apresentam de forma centralizadora e normatizadora, desconsiderando a cultura local: os saberes, os valores, os modos de agir e pensar, os comportamentos construídos no cotidiano escolar. Essa cultural mais específica será aqui denominada de cultura da escola, para estabelecer uma distinção entre a cultura escolar que, grosso modo, refere-se aos conceitos que foram sendo agregados à ideia de escola e que criou uma identificação genérica dessa instituição.

A coordenadora Maria Vitória, no contexto dessa discussão, realça os aspectos de singularidade que caracterizam determina instituição escolar e, que, de certo modo, a identificam dentre as demais, chamando a atenção para a importância da 'cultura da escola' na organização da formação contínua dos docentes:

Eu acho que a cultura escolar, tanto compreende o universo dos saberes que existem, os saberes historicamente construídos, mas, também, passa pela experiência das pessoas, o jeito de cada escola, quando a gente fala de cultura escolar não dá para generalizar.

De acordo com a coordenadora Maria Augusta, a cultura da escola, por vezes, manifesta uma concepção generalizada de que o professor da escola pública deve ser deixado quieto, não precisa ter compromisso com o tempo de aprendizagem dos alunos, pois para esses professores as dificuldades de aprendizagem estão normalmente relacionadas a fatores dissociados de sua ação docente. Então, o aluno não aprende porque é de família carente, desestruturada, porque a escola não tem condições materiais ou porque o coordenador não resolve os problemas. No dizer dela: 
Este grupo de professores [...] são os fieis adeptos da cultura da escola, querem que deixem o professor quieto, afinal ele é funcionário público. Não tem compromisso com o tempo, se der para fazer tudo bem [...]. Ninguém falou que o professor não tem que ensinar, tem que ensinar e o aluno tem que aprender. Sabe, essas distorções fazem parte da cultura da escola e eu acho que nós temos que ir desmontando essas coisas.

Para alguns grupos de professores e algumas escolas, a formação é um momento de encontro, de catarse, mas nunca um espaço sério de reflexão profissional. O professor não quer ser incomodado, ser desafiado ou mesmo ver questionada a sua ação pedagógica. Só quer fazer o que sabe, mesmo que o que saiba não esteja produzindo o saber no outro.

O desafio da coordenação pedagógica está em não se sentir impotente diante de tal situação. Essas ideias, de um coordenador que manda e um professor que obedece, são tidas como "distorções" que precisam ser enfrentadas e desmontadas para a construção de uma nova etapa de formação.

Nessa perspectiva, é importante considerar que as muitas interações culturais que a escola possibilita e que interferem na dinâmica constituída pela sua forma de organização, mediada pelo contexto social, podem agregar novos valores e novas ideias à comunidade educativa e à gestão desenvolvida nesse espaço.

Deve-se considerar, também, que a cultura institucional escolar recebe influência das reformas educativas, configuradas nas decisões das políticas públicas em relação à educação e, nesses casos, elas são externas e são impostas à revelia da vontade dos agentes implicados: professores, diretores, coordenadores pedagógicos, alunos, pais etc. Pérez Gómes (2001, p.195) corrobora essa ideia quando afirma:

A escola é uma instituição social e, por isso mesmo, inevitavelmente impregnada pelos valores circunstanciais que imperam nos intercâmbios de cada época e comunidade. Para cumprir sua função pedagógica com relativa autonomia, o docente deve estar atento e enfrentar e superar em si mesmo e na cultura da escola os influxos meramente reprodutores da dinâmica social.

Forquin (1992, apud FARIA FILHO et alii, 2004, 147) acrescenta a essa análise a ideia de cultura escolar transpostas, subordinada e determinada pela sua própria organização:

A cultura escolar apresenta-se assim como uma cultura segunda com relação à cultura de criação ou de invenção, uma cultura derivada e transposta, subordinada inteiramente a uma função de mediação didática e determinada pelos imperativos que decorrem dessa função, como se vê através destes produtos e destes instrumentos característicos constituídos pelos programas e 
instruções oficiais, manuais e materiais didáticos, temas de deveres e exercícios, controles, notas, classificações e outras formas propriamente escolares de recompensas e de sanções. (grifos do autor)

Os dois autores apontam aspectos significativos da cultura escolar que podem influir na atividade formativa na escola. O primeiro aspecto é a relativa autonomia do docente, e por extensão, do coordenador e da escola que precisa estar voltada para a construção crítica de um trabalho pedagógico que não se constitua como reprodutor das práticas sociais. Essa ideia exerce influência, também, nos projetos de formação docente desenvolvidos na escola sob a liderança do coordenador pedagógico. $\mathrm{O}$ trabalho coletivo na escola precisa estar voltado para a análise dos projetos externos que adentram a escola e dos próprios projetos usando como critério a concepção formativa da unidade e as necessidades elencadas pelos professores.

O segundo aspecto está relacionado à cultura da reprodução, mais próxima da cultura escolar, do que a cultura da colaboração, da pesquisa, da construção e da valorização do conhecimento docente. Uma cultura tão arraigada pode influenciar tanto na adesão a projetos externos, como na construção de projetos comprometidos com valores que não promovam a autonomia de professores e alunos, sujeitos do processo educativo. Assim, é que, se utilizando da relativa autonomia dos processos formativos, os grupos precisam optar sobre a formação necessária para o desenvolvimento do trabalho docente.

O coordenador tem papel importante nesse aspecto, pois, como foi relato pelas coordenadoras, os programas e as instruções oficias de formação docente apostam no coordenador como parceiro na implementação de um projeto formativo elaborado por pesquisadores.

O coordenador, pautado pelo projeto político pedagógico da escola, entendido como desenvolvendo um papel de liderança pedagógica, configura-se como um instrumento para o desvelamento dos entraves produzidos pela cultura escolar e local, bem como pelos projetos e programas oficiais.

A formação proposta na escola, como já foi enfatizado, tem a vantagem de abrigar no mesmo espaço a prática educativa e a reflexão crítica sobre esse saber-fazer, porém esta tarefa acaba se concentrando na ação didática. Como assevera Sacristán (1995, p. 68) “[...] a actividade dos professores não se circunscreve a esta prática pedagógica visível, sendo necessário sondar outras dimensões menos evidentes". Assim, o coordenador e a equipe escolar precisam estar atentos para favorecer uma formação que não se caracterize como instrucional, mas que promova a análise das práticas formativas propostas para e pela escola, de modo a antever suas conseqüências no estatuto da profissão docente. 
A formação centrada na escola, além de sua dimensão coletiva, possui uma outra individual que também caracteriza o trabalho realizado nessa instituição. Canário (2006, p. 66) dá destaque às singularidades pessoais e organizacionais na formação centrada na escola. Para o autor, é no jogo entre o coletivo (de professores) e o individual (professor ou coordenador) que se estabelecem as práticas pedagógicas e, por que não dizer, de formação centrada na escola. Nas palavras dele:

Os professores exercem a sua atividade profissional no contexto de organizações escolares que se definem como sistemas de comportamentos, isto é, que correspondem a sistemas de ações coletivas, no seio dos quais os atores individuais produzem e aprendem simultaneamente as respectivas regras. Cada escola constitui um contexto único, marcado pela sua singularidade. A produção de práticas profissionais é o resultado do modo como se cruza esta singularidade com as trajetórias individuais dos respectivos profissionais. O funcionamento de cada escola, como acontece nas outras organizações sociais, assemelha-se, assim, a um "jogo coletivo", que é determinado, por um lado, por dimensões coletivas (organizacionais) e, por outro, por dimensões individuais (de natureza biográfica).

Nesse jogo o papel atribuído ao coordenador pedagógico não se limita à observação da aula e à análise da prática, mas vinculá-se à articulação de toda reflexão pedagógica na escola podendo criar um ambiente de cooperação e de pesquisa que possibilita ao professor colocarse no papel de investigador de sua própria prática e de idealizador das transformações necessárias para gerar a aprendizagem dos alunos. Caracteriza-se, assim, por ser uma estratégia formativa intencionalizada num ambiente cooperativo e democrático. A ação do coordenador pedagógico, nesse sentido, está ligada impreterivelmente ao trabalho desenvolvido pela escola, o que o aproxima ainda mais das dificuldades identificadas pelos professores. Tal aspecto produz um maior impacto sobre as práticas culturais da escola. $\mathrm{O}$ formador (coordenador pedagógico) precisa cuidar para que a formação proposta não tome pura e simplesmente a 'forma' da cultura escolar, ou a 'forma' das proposições oficias. $\mathrm{O}$ formato ideal é aquele que responde de modo crítico às dificuldades dos profissionais na escola.

Um outro aspecto importante a ser considerado no desafio imposto ao coordenador diz respeito à influência de determinados aspectos da cultura escolar nas ações e nos projetos desenvolvidos.Uma marca muito conhecida é o isolamento docente ${ }^{65}$ que impõe restrições ao trabalho coletivo e pode inviabilizar a 'crença' no projeto político-pedagógico como a síntese das intenções acordadas pelo coletivo escolar. 
O grupo da escola rompe a cultura escolar calcificada quando quebra o isolamento e se vê ligado a outros profissionais. Para Pérez Gómes (2001:169):

O isolamento é o ambiente adequado para o cultivo do pragmatismo, da passividade, da reprodução conservadora ou da aceitação acrítica da cultura social dominante. A ausência de contraste, de comunicação de experiências, possibilidades, idéias, recursos didáticos, assim como de apoios afetivos próximos, reforça o pensamento prático e acrítico que o docente adquiriu ao longo da sua prolongada vida na cultura escolar dominante.

Nesta perspectiva, o trabalho coletivo é uma das possíveis saídas contra o individualismo e o isolamento ligado à atividade docente na escola. Além de constituir uma identidade integrada, referenda o projeto político pedagógico como uma construção coletiva que expressa uma concepção partilhada.

O coordenador pedagógico tem um importante papel nesse processo, pois ele é o gestor-crítico, cooperativo, responsável pela observação das práticas, pela propositura das reflexões, pelas intervenções no sentido de promover o compromisso coletivo e cooperativo no desenvolvimento das ações formativas que desembocam em práticas reflexivas. Caso contrário, pode assumir um papel de mero executor das determinações das políticas públicas, principalmente em relação à formação desenvolvida na escola. Conforme afirma Pérez Gómes (2001, p.184):

[...] o conhecimento e a prática profissional do docente devem abarcar todos os aspectos que definem a complexa rede de intercâmbios, nos quais se move sua atuação. Reduzir-se à dimensão técnica ou de gestão administrativa o converte num fantoche ingênuo ou cínico, a serviço de forças externas $[\ldots]$ que sufocam sua iniciativa em demandas contraditórias.

A cultura da escola vai gradativamente moldando os educandos e os educadores, tanto pelos seus aspectos organizativos (os projetos desenvolvidos), quanto por aqueles relacionados à cultura docente. Nesse sentido, a formação do docente assume a importância de promover a reflexão sobre os fazeres e os saberes desenvolvidos na escola, construindo parâmetros que promovam a transformação crítica dessas práticas.

A cultura escolar, em suma, revela os fatores que regem a escola, o modelo de organização e o comportamento das pessoas. Esses aspectos podem, de um certo modo, caracterizá-la, criando uma identidade particular, ainda que difusa e mutante. Uma das 
coordenadoras entrevistadas faz uma consideração sobre uma prática específica que ajuda a entender essas idéias:

Na Educação Infantil existe uma cultura da higienização, não que seja boa ou má, faz parte da cultura escolar e é forte e ampla. Está em todo lugar, por exemplo, [...] tem a escovação, o lavar as mãos, a higienização após os lanches.Outro aspecto [...] é a espera, a criança tem que esperar sua vez, esperar para pegar o lanche, esperar para ir ao banheiro, esperar para entregar a lição etc.. Esta cultura do esperar na EMEI é forte. Diminuímos este momento na entrada, as crianças entram e é o professor que está esperando na sala. (COORD. MARIA LEDA; grifo nosso)

$\mathrm{Na}$ percepção da coordenadora Maria Leda, alguns aspectos da cultura escolar orientam de forma pouco reflexiva as ações pedagógicas. O trabalho com a higiene faz parte do contexto pedagógico na educação infantil, é algo que congrega o cuidar e o educar e não deve estar descolado do projeto de escola e de outras ações educativas, não pode se constituir em uma ação isolada, descaracterizada do seu cunho pedagógico.

A coordenadora também aponta, em relação à cultura da escola de educação infantil, o condicionamento para esperar. É certo que na sociedade existe a espera, mas na escola a espera torna-se um elemento a ser questionado e não naturalizado. Isso porque a espera nesse espaço pode ter uma função condicionante que permeia todas as atividades, desde a entrada até a saída. As crianças esperam na fila a chegada dos colegas, esperam sua vez de serem servidas no lanche, esperam para ir ao banheiro, esperam para brincar no brinquedo, esperam a entrega do caderno para começar sua lição, esperam para falar na roda de conversa, esperam para serem atendidas pela professora, esperam os pais na saída. Perceber esse tempo enorme de espera na escola e questionar essa necessidade é promover mudanças e adequações no projeto pedagógico da escola, é problematizar uma cultura. A falta de percepção desses aspectos leva à reprodução de ações que, sem a devida reflexão, não produzirá no aluno a crítica que favoreça as mudanças sociais necessárias. Por que a espera ocupa um tempo tão grande no nosso currículo? Esse é um tema para a formação, para a reflexão do docente.

A coordenadora Maria Leda relata que a formação contínua na escola é um espaço importante para o questionamento da cultura escolar de educação infantil. Mesmo os professores não enxergando os problemas por trás de algumas ações, ainda assim, são temas que merecem ser tratados porque compõem parte do currículo oculto, que precisa ser desvelado para gerar ações mais críticas. O horário coletivo, o projeto de formação e a ação do coordenador pedagógico devem estar a serviço da construção de um ensino de qualidade para todas as crianças. 
O relato que segue, sobre o canto das crianças na entrada à escola, revela como atos simples, pautados numa concepção acordada, podem transformar uma realidade aparentemente imutável e confortável. O trabalho da coordenação pedagógica não é apenas questionar, mas propor mudanças, implementá-las e depois avaliá-las, junto com a equipe, para que percebam as diferentes tomadas de posições e o que está envolto nas ações desenvolvidas no ambiente escolar:

Rever a situação foi uma solicitação da diretora. Ela achava um absurdo fazer nove filas, era uma barulheira e ficava todo mundo em pé esperando todos chegarem para subir para a sala. Esse período era organizado para todos cantarem, mas eram sempre as mesmas turmas que cantavam, os outros não queriam cantar nada e tinha dias que não cantavam, só ficavam em pé esperando todos chegarem. Então decidimos fazer um teste, cada criança subiria direto para a sala e o professor ficaria aguardando lá e se quisessem poderiam cantar. Mesmo porque, o trabalho com música não é isso, ficar cantando na entrada, no meio ou na saída. Teve professor que achou que não daria certo, que seria uma bagunça. As crianças iam se perder porque não sabiam para que sala ir, porque elas mudavam de sala, a cada dia entravam numa sala diferente. Combinei que era para o professor ficar na porta e fizemos a experiência, depois nós avaliamos e deu certo. Nessa escola, ao contrário da outra de onde vim, eu não tenho nada muito cristalizado. (COORD. MARIA LEDA; grifo nosso)

O depoimento revela que é possível mudar e organizar uma escola diferente e eficiente para todos que a ela têm acesso. A formação na escola tem o papel de fazer esta introspecção no espaço escolar, nos seus projetos, na sua forma de organização e, a partir da ações do educadores que ali trabalham, questionar as 'verdades' que não produzem a formação desejada. No final do processo, conforme o relato da coordenadora, os professores entenderam que "a mudança deu certo" e talvez tenham percebido que desse jeito ensinaram às crianças que nem sempre é preciso esperar. É possível também falar sem levantar a mão, andar pelos espaços e descobrir o que se quer, mesmo que seja, apenas, a sala de aula do dia.

Pensar a cultura escolar como um elemento a ser considerado nos projetos de formação é, com certeza, provocar resistências. Numa proposição aparentemente simples, como a orientada pela coordenadora Maria Leda, houve resistências, mas a avaliação final demonstrou que a mudança trouxe benefícios para as crianças e para os professores. Segundo a coordenadora, a mudança dos professores foi possível "porque não havia nada muito cristalizado" na cultura daquela escola. Com apenas cinco anos de organização, aquela instituição estava construindo coletivamente uma identidade que se propunha a descartar alguns aspectos da cultura escolar e a abraçar outros e, assim, dar forma a uma cultura escolar 
local. Tais práticas culturais locais ditam as formas de trabalho e propõem jeitos diferentes de promover a educação das crianças e dos jovens. Os espaços de formação e o trabalho da coordenação consolidam esses momentos de reflexão e de tomada de decisões em relação ao currículo escolar, que alteram o trabalho docente e a aprendizagem dos alunos. Situação essa apontada por Libâneo (2003, p 83):

Sabemos que o trabalho nas escolas se defronta com características culturais
dos alunos, que afetam sua participação nas aprendizagens. Também os
professores são portadores de características culturais - seus saberes, seus
valores, e seus quadros de referências, as formas com que lidam com a
profissão - que marcam fortemente as práticas docentes. Mas, o que se quer
destacar aqui, é que as próprias práticas e situações escolares estão
impregnadas de uma cultura, que é a cultura da escola [...] afetando tanto
professores como alunos.

O ensino fundamental, por suas especificidades, apresenta outros aspectos associados à cultura escolar. Quem nunca ouviu falar da cultura da reprovação, da cultura das salas homogêneas, da cultura da seriação, da cultura do individualismo e da cultura do livro didático? Por trás da manutenção desses conceitos está a ideia de uma escola que não muda, que não se repensa, nem considera as demandas da atualidade. São conceitos que, embora questionados pelo avanço dos conhecimentos referentes aos modos de aprendizagem, às relações humanas, às organizações cooperativas, ao trabalho coletivo, ainda são referências que afetam o modo de ser e aprender, de professores e de alunos.

Vale a pena destacar, novamente, que a cultura escolar não é algo que possa se caracterizar como boa ou ruim. Mas será melhor à medida que se torna flexível e reflexiva. $\mathrm{O}$ projeto político pedagógico, como produto de uma ação coletiva, absorve parte da cultura da escola, ao mesmo tempo em que pode consolidar e recriar uma cultura alternativa. Assim, a coordenação pedagógica em uma escola pública precisa estar atenta:

- Às representações construídas e incorporadas pela cultura da escola local;

- Às demandas reais que a função determina;

- Às solicitações das políticas públicas, que podem atribuir ao coordenador a imagem de controlador;

- A um trabalho em favor de um projeto que valorize a cultura colaborativa e os saberes docentes.

Segundo Libâneo (2003, p.196): 
A cultura colaborativa será a síntese dos elementos que asseguram a relação entre a organização escolar e o desenvolvimento pessoal e profissional dos professores: o projeto pedagógico-curricular, a gestão, a organização e articulação do currículo e a formação continuada.

A coordenadora Maria Vitória entende que a cultura da escola envolve tanto o que os alunos aprendem e levam para a vida toda, como aspectos específicos de uma determinada organização escolar que podem caracterizá-la como menos ou mais colaborativa. Ao descrever a escola na qual trabalha, em relação a esses aspectos, faz a seguinte declaração:

Eu acho que nesta escola tem muita gente comprometida, gente que faz, embora tenha mil coisas que precisem ser melhoradas, que não está bom. Mas há profissionais que se preocupam com os alunos, têm ações diferenciadas (que já faz parte da cultura dessa escola), sempre se preocupando em estar proporcionando vivências para os alunos, atividades dentro e fora da escola [...], acho que tem muita gente qualificada, que estuda e que é comprometida com a causa da educação. (comentário nosso)

Pode, então, a cultura da escola influir no estilo de gestão da formação contínua do docente, cujo locus é a escola? A resposta para essa questão possivelmente seja sim. A cultura da escola tanto influencia que pode orientar a forma como o coordenador pedagógico deve comportar-se frente às demandas de formação do docente. Então, cabe uma segunda questão: Como a cultura da escola influi no estilo de gestão da formação contínua do docente, cujo locus é a escola? E para essa pergunta com certeza as respostas são múltiplas e este trabalho é apenas uma das possibilidades de resposta.

Assim, mudar aspectos da cultura escolar pode significar engajar-se num processo de 'reforma educativa' em nível micro, na escola, apoiada por um projeto político pedagógico, ou construído conjuntamente entre escola e sistema de ensino. Quando só a política educacional, macro, assume essa tarefa, ela passa a configurar-se por um corpo de normas que vai, paulatinamente, elaborando modelos que dão existência às ideias que serão expostas. Esse processo, visto de cima para baixo, desconsidera as peculiaridades dos projetos formativos desenvolvidos nas escolas, bem como a atividade do profissional que o coordena. Nesse caso, as ações são homogeneizadoras para que o sistema possa fazer o controle.

A política educacional está de alguma forma imbricada com a cultura escolar, reforçando-a ou opondo-se a ela por meio das reformas educacionais. Contudo, constitui-se em um aspecto estruturante da compreensão da ação do coordenador, mais especificamente da política de formação de professores e dos profissionais de educação, que, como toda a 
política educacional, normalmente está vinculada à política dos partidos que administram a situação pública que, grosso modo, são as diretrizes ou a linha de ação que norteiam a prática educativa, a fim de alcançar os objetivos traçados pelo poder público, operacionalizada nos equipamentos educativos. Segundo Souza (2005, p.52):

O dever do Estado não é impor pacotes que consideram adequados para atingir as suas diferentes lógicas, mas sim o de formular propostas que garantam a participação efetiva dos educadores nas decisões.

Todavia, não é isso o que acontece. Os pacotes surgem travestidos de programas facultativos, sujeitos à análise e à opção das escolas, e acabam configurando-se como determinações.

A descontinuidade das ações formativas na escola está também relacionada às interrupções das políticas públicas que, a cada mudança de governo, impõem uma reestruturação das ações formativas construídas pela equipe escolar, negando o tempo histórico e mantendo as relações de poder verticalizadas.

Nessa perspectiva, torna-se igualmente importante conhecer e entender a influência das políticas educacionais na formação dos professores, pois, por representar o desejo de quem administra a instituição pública, assume a força do 'cumpra-se', que não considera questionamentos. Conseqüentemente, o trabalho dos coordenadores pedagógicos sofre tais influências, especialmente por ser ele responsável por parte da gestão do espaço escolar. Marcelo Garcia (1999, p.193) argumenta que:

[...] os processos de desenvolvimento profissional são claramente determinados pela política educativa de momento, sendo tal política concretizada em questões referentes ao currículo, à organização e ao funcionamento das escolas. Assim fica claro que é a Administração Educativa quem determina as "prioridades da formação" dos professores para que estes se tornem mais aptos a desenvolver a política educativa planificada a nível oficial.

Falar em ausência de políticas públicas é, muitas vezes, negar as políticas que não beneficiam o trabalho na escola, que não reconhecem os processos já elaborados, que desprezam esses saberes. A 'cultura' da descontinuidade e da fragmentação das políticas implementadas pelo sistema parece confirmar esse discurso. Mas elas existem e são responsáveis, em certa medida, pelos processos de formação dos educadores e pelo desenvolvimento da formação na escola sob a articulação do coordenador pedagógico. 
Quando as condições são negadas, criam-se constrangimentos organizacionais, conceituais e outros. Existe, aí, um trabalho em prol de uma política pública que pode estar investindo na individualização e não na colaboração.

O discurso da escola como lugar de formação para o professor vem sendo incorporado por diversos segmentos como os constituídos por teóricos, revistas especializadas, gestores de políticas públicas, coordenadores pedagógicos e professores. Sendo assim, o conceito está sujeito a interpretações e intervenções diversas de modo que cada um acresce uma nuance diferente: a equipe escolar, com sua cultura organizacional; a administração pública e sua política de formação; os pesquisadores e suas análises. Essa é também a leitura de Marcelo Garcia (1999, p.141):

Actualmente é lugar comum entender a escola como a unidade básica de mudança e formação, conforme vem sendo assumido não apenas por investigadores e formadores, mas também pela Administração Educativa $[\ldots]$

Assim, a formação contínua na escola está sujeita a uma compreensão por parte da administração educativa que vai orientar o trabalho do coordenador pedagógico, estabelecendo suas prioridades formativas, os princípios que a nortearão e a forma como se dará o acompanhamento.

Num espaço tão plural quanto a instituição escola, a cultura escolar compõe-se de forma multifacetada, fruto das inter-relações e correlações de poder que o espaço possibilita e que compõe a rede de significados compartilhados. Segundo Pérez Gómes (2001), o campo da cultura é também de produção de sentidos e, por isso, na escola é importante considerar não uma cultura, mas um entrecruzamento de culturas que, no decorrer do tempo, vão reelaborando a identidade de seus sujeitos.

Assim, o coordenador pedagógico está implicado nessa dinâmica, que envolve as características da cultura escolar, a influência das políticas públicas, as demandas e necessidades locais e os fatores relacionados às atribuições dessa função, recriando o sentido de coordenar aspectos relativos à formação na escola.

2. Aspectos relevantes e intervenientes da formação contínua centrada na escola na visão de professores 
A formação na escola tem como característica a valorização dos conhecimentos produzidos pelos professores na prática pedagógica diária e a interação entre os professores e o coordenador pedagógico. Isso não significa valorar todas as práticas docentes na escola, mas sim construir uma reflexão crítica sobre elas, de modo que os professores desvelem as teorias por trás de seus saberes e fazeres.

Essa relação intrínseca entre os docentes e o coordenador pedagógico na formação contínua desenvolvida no espaço escolar estabelece como demanda dessa investigação a oitiva dos professores sobre o espaço formativo na escola.

Com relação a isso, foram ouvidos dezenove professores das duas escolas onde se desenvolveram os processos de observação, numa dinâmica denominada grupo dialogal ${ }^{66}$. Os depoimentos dos professores nos auxiliam na compreensão do trabalho do coordenador na formação centrada na escola. Eles estão sintetizados no quadro a seguir:

\section{O PEA na visão dos professores}

\begin{tabular}{|c|c|}
\hline & \\
\hline $\begin{array}{l}\text { "Troca de experiência seria o momento de } \\
\text { discutirmos o que acontece na sala de aula, de } \\
\text { colocar os aspectos positivos e as dificuldades que } \\
\text { nós encontramos. Mas eu acho que isso não } \\
\text { acontece no PEA [...], nós nos propusemos no } \\
\text { começo a fazer um momento de troca de } \\
\text { experiências. Até cogitamos fazer oficinas } \\
\text { relacionadas a alguns temas como artes e depois ter } \\
\text { um momento de troca para saber como aconteceu em } \\
\text { cada sala". Prof. A } \\
\text { "Nós sabemos que tem colegas no grupo que fazem } \\
\text { um trabalho muito legal na escola . Nós não temos } \\
\text { o hábito de registrar e nem de mostrar os trabalhos } \\
\text { legais, que funcionaram. Mas, seria bastante útil que } \\
\text { mostrássemos essas práticas e as multiplicássemos, } \\
\text { pois elas podem ser adaptadas para a minha } \\
\text { realidade". Prof. D } \\
\text { "É importante trocarmos experiência no horário da }\end{array}$ & $\begin{array}{l}\text { trazer coisas para ser incorporado aqui, a } \\
\text { nedagogia' dos cantinhos de atividade, ela entrou } \\
\text { o material e nós fomos estudando e } \\
\text { experimentando e acabou que rolou meio } \\
\text { garganta abaixo de todo mundo. Prof. B (grifo } \\
\text { nosso) } \\
\text { "Acho que a teoria é importante sim, sem teoria } \\
\text { nós não chegaríamos a lugar nenhum, o que eu } \\
\text { critico nessa nova administração é que eles vêm } \\
\text { com algumas coisas como se fossem a descoberta } \\
\text { da pólvora, como a sequiência didática, mas para } \\
\text { mim isso não é grande novidade e nós ficamos } \\
\text { batendo nessas teclas e deixando de discutir } \\
\text { algumas coisas, talvez o mais importante. Mas eu } \\
\text { não nego a teoria, em absoluto, eu nego algumas } \\
\text { formulas prontas que chegam e nós ficamos } \\
\text { perdendo tempo nisso". Prof. B- (grifo nosso) }\end{array}$ \\
\hline
\end{tabular}


professor de matemática que foi vivenciada no grupo, me ensinou coisas que eu não sabia, aprendi naquele momento, apesar de saber matemática e dar aulas de matemática para as crianças. Se houvesse mais aulas para a gente trocar idéias, eu acho que seria mais válido do que as teorias”. Prof. D

"A única coisa que eu percebo é que nós precisamos de um dia, o que não aconteceu ainda esse ano, para o grupo reunir-se, em suas respectivas áreas, para fazer o re-planejamento. [...] que é a troca de experiência, dentro de uma área, como nas demais áreas. $\mathrm{O}$ que funciona em português, inglês, geografia [...], é isso que está faltando [...]”. Prof. P

Uma coisa que auxiliaria a gente na sala de aula, seria levar para lá as experiência que a gente tem aqui e aplicar com os alunos". Prof. C

\section{TRABALHO COLETIVO}

"O que é legal é a participação de todos, teve um ano que nós organizamos o grupo de JEI só com três pessoas, nós discutíamos mas não era assim tão produtivo. Agora que o grupo está maior, parece que a coisa rende mais, a discussão flui e é bem mais gostoso". Prof. B

"Como ponto a ser reforçado coloquei o trabalho coletivo e interdisciplinar, na verdade o trabalho que a gente faz aqui deveria resultar num maior trabalho coletivo lá com o aluno na sala de aula. Acredito que o grupo e a articuladora seriam capazes, não sei o que está faltando, mas a gente pode chegar lá".

Prof. C

"Eu coloquei o trabalho coletivo como um ponto a ser reforçado, às vezes quando estamos discutindo o PEA, acabamos encaminhando algumas lições. Alguns colegas não se manifestam ou se sentem constrangidos em dizer que não vão conseguir desenvolver aquela atividade. Então o que acontece, chega na hora de colocarmos em prática e não funciona, não dá certo, porque o trabalho coletivo
O PEA é para a gente discutir e refletir sobre o que nós vivenciamos. Então eu tenho a impressão que nós falamos, mas não somos ouvidos e no planejamento somos ignorados.É como se dissessem - O trabalho de vocês fiquem para lá e vamos falar sobre isso aqui - (Referindo-se à publicação da rede). É uma teoria imposta, falta uma reflexão sobre o que nós queremos". Prof. E (grifo nosso)

"Em relação ao PEA, do ano passado para cá houve uma reviravolta. Porque até então nós tínhamos projetos que eram concretizados. Nós líamos para efetuar um trabalho em sala de aula, mas depois veio essa coisa ai, que de um modo geral não está refletindo, que é essa coisa que veio lá da SME. A coisa veio goela abaixo, acho muito ruim essa formação que a prefeitura está dando [...], inclusive atrapalha o trabalho que nós estamos fazendo, uma coisa que não nos consultaram, então o PEA ficou algo muito ruim por causa disso". Prof. A (grifo nosso)

"Eu acho que nos vivemos um momento em que nosso grupo tem um amadurecimento que não precisaria ficar preso, como ele está, nessa camisa de força, que é o que a administração deseja". Prof. I (grifo Nosso)

\section{DISCUSSÕES DESVINCULADAS DA REALIDADE}

"Nós começamos esse trabalho com o texto, a seqüência didática, quando menos se espera, vem alguém e diz: - Isso precisa ser entregue amanhã e tem que ser tabulado [...] - e fica aquele atropelo [...]" Prof. J

"Estou falando do momento que a gente está vivendo, vem um monte de teoria e a gente sabe que essas pessoas que fazem essa teoria não entendem absolutamente nada de educação. Alguns deles nunca entraram numa sala de aula, então é teoria demais, deveriam viver mais a prática para saber do que estão falando". Prof. D

Eu desmontaria a forma como, às vezes, o PEA é encaminhado, ou seja, esquece-se tudo aquilo que você acredita que agora vai ser discutido o 'PONTO'". Prof..F

"Discussões impossíveis de se reverterem na prática. Nós temos autonomia prática no nosso dia-a-dia, nós conhecemos que a realidade não é 
precisa ser repensado". Prof. F

SME, nem ninguém, nós a vivenciamos [...]". Prof.A

Quadro 12. Elaborado a partir dos depoimentos dos professores no grupo dialogal

O quadro anterior foi elaborado a partir da coleta das percepções dos professores a respeito do modo como se desenvolve o projeto de formação de suas escolas. Para tanto, eles foram reunidos em grupos dialogais e manifestaram-se a partir da seguinte provocação: Quais os aspectos que os professores desprezariam e os que reforçariam no projeto de formação da escola? Tal indagação produziu como efeito o levantamento de vários fatores intervenientes no processo de formação a partir dos olhares dos professores.

Os aspectos destacados para serem reforçados na visão dos professores foram: a troca de experiências e o trabalho coletivo.

A troca de experiências é um dos elementos do processo de formação muito defendido pelos professores. Fusari (1997 p. 153) relata que tal procedimento é "[...] antigo e garante a superação de dificuldades surgidas no trabalho em sala de aula, ao mesmo tempo que funciona como formação profissional em serviço". Na perspectiva dos professores, a troca de experiências tem vários sentidos: a discussão das dificuldades da sala de aula, a divulgação de 'bons trabalhos', a condução de aspectos delicados do trabalho com pessoas, oficinas com professores mais experientes ou especialistas, a discussão por área, o planejamento a partir das atividades formativas, vivenciadas com os alunos e retomadas nas discussões.

Essa troca pode então constituir-se em uma sugestão de trabalho ou num processo coletivo de reflexão sobre a ação. Portanto, sua multiplicidade de configurações, bem como a valorização da participação ativa dos professores, consolida na visão desses profissionais um aspecto positivo de formação, que deveria ser reforçado no horário coletivo de formação. A troca de experiência articulada pela coordenadora da Escola A, normalmente, objetivava o relato das sequências didáticas planejadas. A socialização do resultado da atividade não se prestava ao levantamento das dificuldades, mas para enfatizar as vantagens dessa organização do trabalho. Na Escola B, as trocas aconteciam de forma assistemática, à medida que as professoras participavam das discussões no grupo e eram introduzidas pelas expressões: " $\mathrm{Na}$ sala, eu fiz assim[...]"; "Apliquei tal trabalho com as crianças[...]"; "Essa atividade eu adaptei [...]". As professoras eram incentivadas pela coordenadora a esse tipo de relato; caso algum não estivesse incluído na concepção trabalhada, a coordenadora fazia os ajustes, quando usava da palavra. 
Um segundo aspecto reforçado pelos professores é o trabalho coletivo, que ganha o sentido de partilha, de decisões compartilhadas, de envolvimento nas decisões e na busca de soluções para os problemas da escola. A perspectiva do trabalho coletivo se opõe ao individualismo e procura favorecer a discussão sobre a prática ou sobre a teoria, reflete as elaborações da formação e envolve a todos, independente dos conhecimentos ou das habilidades pessoais.

Reforçar este aspecto na organização do projeto especial de ação (PEA) da escola não se limita apenas a organizar as reuniões de formação, mas exige construir uma disposição para refletir junto sobre o projeto da unidade, dando-lhe concretude. Nesta perspectiva, o trabalho coletivo e a troca de experiências caminham juntos. O primeiro, relacionado à socialização dos saberes dos professores no processo formativo. O segundo, associado a uma re-elaboração coletiva dos primeiros saberes, que se transformam em propostas de trabalho.

Os dois aspectos elencados atribuem à escola e aos seus profissionais, professores e coordenadores, o papel de protagonistas tanto na elaboração, quanto na condução dos processos formativos vivenciados no espaço escolar. Frente a essa situação, o coordenador pode assumir duas posições. A primeira é a apresentada pelo Prof. C, que é acreditar no projeto da escola e no papel da coordenação pedagógica como articuladora do espaço de formação. A segunda posição é a destacada pelo Prof. J, segundo o qual o coordenador se vê como uma pessoa que não tem o controle sobre o seu fazer, por isso também não tem responsabilidade sobre a insatisfação do coletivo de professores. A formação é desenvolvida sob o controle dos órgãos oficiais que ditam sua configuração:

Cada dia, cada ano, nós educadores estamos com uma sobrecarga cada vez maior, existe também uma questão burocrática, são atividades colocadas, apresentadas. Eu vejo que a coordenação não tem culpa de todo esse processo, isso vem lá de cima. Prof. J

Um coordenador que não tem culpa e nem compromisso com a transformação está submisso e dessa forma é incapaz de mobilizar os professores para a transformação, para a construção do protagonismo formativo. Nesse caso, a expressão "vem lá de cima” parece referir-se a um espaço místico, onde a vida profissional e a formação docente é decidida por aqueles que pensam a educação, já que os professores e os coordenadores estão no papel de práticos. Quem está acima, está numa posição superior, de mando, de imposição de ideias. Essa situação lembra a máxima “manda quem pode, obedece quem tem juízo.” 
Os professores destacaram como aspectos que desprezariam: as imposições teóricas e o atropelo de atividades. Ao considerar as imposições teóricas como fator interveniente a ser desprezado, os professores trouxeram à superfície as formas de controle que estão implícitas nos projetos externos à escola, normalmente associados aos programas de governo que adentram os espaços formativos pela mão da coordenação.

Os professores referem-se a essas intervenções com as seguintes expressões: “[...] rolou meio garganta abaixo de todo mundo” (Prof. B) ou, como disse outro professor, “[...] mas depois veio essa coisa aí de SME. A coisa veio goela abaixo” (Prof. C ), que são usadas para sublinhar o sentimento de imposição violenta sobre um outro saber, indicando o quanto os professores e o projeto da escola foram desconsiderados.

Outras sentenças usadas foram "[...] essa administração vem com algumas coisas como se fossem a descoberta da pólvora[...]" (Prof. B); “[...] é uma teoria imposta[...]." (Prof. E); “[...] nessa camisa de força [...]” (Prof. I). Essas expressões destacadas nesse parágrafo revelam que os 'conceitos ou teorias', como eles dizem, que chegam à escola não são negociadas. Não se discute com os professores seus saberes nem suas sugestões sobre as soluções para os problemas elencados pela escola. Os professores ficam à margem desse processo, apenas recebendo a formação que deve se transformar em uma prática, para alguns, "[...] uma camisa de força [...]" que impede movimentos próprios, limita a criação, a discussão e imobiliza o professor. O coordenador, nesta perspectiva, é apenas uma peça de engrenagem que faz valer as determinações externas, não tem força ou poder para mudar tal situação.

Os relatos das coordenadoras também revelaram que as interferências nos projetos de formação acabaram por desmobilizar a escola, que já havia construído uma estrutura formativa e que precisava de ajuda para aperfeiçoá-la e não desmontá-la. Nesse aspecto, não houve contradição entre a fala de coordenadores e professores. Isso revela a pouca autonomia da escola e indica a natureza do controle que o coordenador pedagógico tem sobre o espaço formador da JEIF. Esta estrutura de formação centrada na escola vai numa direção oposta daquela defendida por pesquisadores desse tema. Segundo Canário (2006, p. 75):

A construção da autonomia dos estabelecimentos de ensino supõe uma capacidade autônoma de mudança que não é compatível com processos de controle remoto das escolas e dos professores, a partir da administração central. A formação "centrada na escola" é uma das facetas de uma nova visão do estabelecimento de ensino, no qual ele é, simultaneamente, uma unidade estratégica de mudança e a unidade central de gestão do sistema. $\mathrm{O}$ projeto educativo da escola constitui o instrumento essencial de uma gestão 
estratégica do estabelecimento de ensino, cujas construção e avaliação, nas suas diferentes formas, configura-se como o eixo fundamental de um processo de formação contínua dos professores. É, portanto, em um plano mais global, balizado pelo projeto educativo da escola, que o plano de formação deve ser pensado.

Os coordenadores revelaram que o trabalho de formação na escola é possível, principalmente quando os professores estão envolvidos na construção desse projeto, apontando suas necessidades, discutindo seus saberes, planejando as atividades e avaliando-o. Em uma das escolas observadas, a percepção que se tinha era do esforço da equipe por tratar das necessidades da escola, no entanto, coincidência ou não, os encontros de formação reproduziam os temas e as pautas da formação vivenciada pelo coordenador. Na outra, uma descaracterização do processo formativo, que teve seu início com o envolvimento dos professores na construção dos primeiros projetos, repercutindo na aceitação da ação das coordenadoras e foi paulatinamente sendo desbastado para atender às solicitações dos órgãos centrais, tornando-se um apêndice da formação proposta pelas equipes da secretaria de educação.

A contradição aparece então como um processo histórico, em que se destacam algumas escolas mesmo com bons projetos, perdendo força e deixando de lutar frente às pressões pela formação indiferenciada. Tal cenário mina a autoconfiança coletiva, quando do estabelecimento pelo controle imediato pelos 'resultados'.

A formação na escola deve propiciar ao professor a possibilidade de discutir, refletir e analisar suas práticas com o objetivo de realizar um trabalho eficiente, capaz de viabilizar, dentre outros processos, a aprendizagem da leitura e da escrita por seus alunos. Na escola A, o projeto que envolvia a leitura e a escrita já acontecia há sete anos. Porém tal fato não foi sequer considerado na formulação do projeto formativo.

Mas, se existem limites criados pelo próprio sistema, também é verdade que existem outros criados pela cultura da escola. Um exemplo disso são as dificuldades dos coordenadores para enfrentarem, na ação formativa, o individualismo que tem caracterizado a profissão docente e a tendência ao desabafo nos horários coletivos. O primeiro impede os docentes de se perceberem como equipe, como coletivo, e administrarem aspectos do trabalho que envolvem questões organizacionais da equipe escolar. $\mathrm{O}$ segundo torna estéril um espaço legítimo para a tomada de decisão sobre os problemas escolares, pois o mero desabafo não é capaz de construir soluções. É preciso enfrentar a situação problematizando as concepções de trabalho e os discursos docentes. O problema não é sempre externo, ele muitas vezes está pautado numa compreensão equivocada de educação e de conhecimento. 
Os professores, nos seus relatos, revelaram a percepção que têm do trabalho do coordenador pedagógico:

Conversando com a coordenadora pedagógica da outra escola, ela me disse que não estava tendo tempo para sentar e organizar as coisas, pois a cada dia ela tem uma cobrança. Então eu vejo que o coordenador pedagógico não tem tempo hábil para dar assistência ao professor, fazer um trabalho de formação e ajudar o professor com dificuldades. (Prof. J)

[...] há uma cobrança sobre o coordenador pedagógico da parte de SME/DOT e nós somos subordinados a ela. (Prof. C)

[...] a coordenação é muito comprometida, nós percebemos a angústia que elas sentem em estar nos auxiliando [...] (Prof. F; grifo nosso)

Quando a coordenadora começou a discutir isso, eu fui um pouco resistente. Primeiro, porque foi uma coisa que veio para nós, não foi imposto, mas a gente teve que fazer. (Prof. A)

Os professores falam sobre uma coordenação pedagógica sem possibilidade de escolhas, rendida diante das determinações das políticas públicas e amarrada pelas regras do sistema. Sem reconhecimento do seu papel e da natureza de suas atribuições, o coordenador é visto como um sujeito angustiado, cujos saberes sobre a sua atividade; sobre a cultura organizacional da escola; sobre os professores, em cuja ação incide sua intervenção; sobre a comunidade em que a escola está inserida são desconsiderados em função de projetos de formação generalistas. Então, para esses professores, o coordenador não articula a formação, ou seja, não dá assistência ao professor em suas dificuldades.

A figura do coordenador, dessa forma, deixa de representar a liderança necessária para a transformação da escola e passa a conformar-se com o papel de reprodutor das determinações do sistema. A escola, então, perde o seu articulador e os professores, a confiança no seu trabalho. Os professores e os coordenadores não são considerados capazes de construir saberes e práticas eficazes sem a devida intervenção e tutoramento externo.

À medida que a escola, professores, coordenadores, diretores perdem a autoconfiança, sentem-se cada vez mais incapazes de elaborar seus próprios projetos, de propor mudanças, de pensar em ações. A escola deixa de construir sua própria possibilidade de intervenção, de exercitar sua autonomia, de formular uma identidade positiva. Assim, a formação na escola deixa de caracterizar-se como fruto de uma decisão coletiva da comunidade profissional interna, mediada por agentes externos, e torna-se o resultado de uma proposição externa, constituindo-se numa forma de o sistema viabilizar sua política educativa. 
Tal reflexão não nega a necessidade da formação contínua do coordenador, ou de orientações advindas do sistema de ensino, porém advoga a necessidade de a escola ser reconhecida como um espaço de construção de saberes de professores e alunos, porque uma característica das ações de formação é saber situá-la num tempo e num espaço, mediada por professores, coordenadores e alunos como sujeitos da elaboração e implementação dos seus projetos de desenvolvimento.

Almeida (2005) chama a atenção para as 'avalanches de ações formadoras' decorrentes das novas questões postas à escola que indicam demandas de natureza distintas, ampliando não só a oferta de formação, mas sobretudo a forma e as possibilidades dessas ofertas. Nesse contexto, a autora não entende a formação contínua resumida a aplicação de modelos previamente estabelecidos, mas como algo dinâmico que compondo o processo de desenvolvimento profissional docente assegura-lhe o caráter contínuo:

Contextualizar a formação no âmbito do processo de desenvolvimento profissional dos professores decorre do entendimento de que a formação contínua se processa como algo dinâmico, que vai além dos componentes técnicos e operativos normalmente impostos aos professores pelas autoridades competentes, que não levam em conta a dimensão coletiva do trabalho docente e as situações reais enfrentadas por esses profissionais em suas práticas cotidianas. Essa contextualização também propicia um caráter mais orgânico às várias etapas formativas vividas pelo professorado, assegurando-lhes um caráter contínuo e progressivo. (ALMEIDA 2005, p.4)

Seja qual for o locus, é necessário, para que a formação contínua produza novos rumos, que seja concebida como uma situação que possibilite a todos um comprometimento com o processo vivido. Nesse aspecto, a escola pode se configurar como um espaço de múltiplas possibilidades, principalmente se o coordenador pedagógico e os professores estiverem criticamente envolvidos, portanto, dispostos a questionar as 'verdades' e as 'certezas' instituídas em relação ao processo de aprendizagem dos alunos e ao desenvolvimento profissional dos educadores. A ação conjunta de coordenadores e professores no tempo/espaço de formação na escola torna-se um fator determinante na formação do docente centrada na escola.

Os depoimentos das coordenadoras e dos professores enfatizaram a importância do papel articulador do coordenador no desenvolvimento de projetos de formação contínua do docente. Mas também a necessidade desse profissional desenvolver cada vez mais uma capacidade crítica e uma competência epistemológica que lhes permitam elaborar e implementar, juntamente com a equipe escolar, os projetos de formação pautados na realidade da escola. No entanto, esse ponto da competência do coordenador parece ser pouco explorado 
na sua formação contínua, principalmente aquela oferecida pelos sistemas de ensino, normalmente voltada para a aplicação dos programas oficiais aos processos formativos conduzidos pelos coordenadores na escola.

Quando a equipe escolar manifesta-se pelo desenvolvimento de um projeto autônomo de formação, o coordenador, com seu trabalho, ajuda a construir uma identidade pedagógica local, baseada na troca reflexiva de experiências, no desenvolvimento de uma postura crítica e criteriosa em relação ao fazer docente. Portanto, a formar um profissional autônomo na elaboração, aplicação e avaliação da tarefa pedagógica. De outro modo, sem a devida análise, pode estar atuando apenas com a transposição didática, sem com isso atingir aspectos conceituais da ação docente. O professor, ao trabalhar com a formação do aluno, o faz como um todo, quando considera seus saberes e a subjetividade característica desse processo. $\mathrm{O}$ coordenador, do mesmo modo, promove a formação do professor quando o enxerga como profissional, cujos saberes só poderão se modificar se for uma escolha pessoal, se houver desejo por formar-se em determinado aspecto do conhecimento. Isso significa que os docentes acreditam ter conhecimentos suficientes para exercer a profissão, então, considerar esses saberes, nesse processo, talvez seja o segredo de aproximá-los de outros saberes e fazeres e desta forma promover de fato o desenvolvimento profissional do professor. 
Embora à primeira vista possa parecer um ufanismo exagerado, é preciso correr este risco de interpretação para trazer à tona que o papel da coordenação pedagógica na implantação de um projeto de formação é essencial, visto tratar-se de um papel de liderança que precisa ser melhor compreendido, reconhecido e valorizado. 


\section{Olgair Gomes Garcia}

A autora em epígrafe traduz o cuidado com que esta pesquisa foi desenvolvida. Longe de se caracterizar pelo ufanismo exagerado em relação à função do coordenador pedagógico na formação contínua do docente na escola, pretendeu investigar a natureza dessa atividade e os aspectos intervenientes nesse processo.

Os participantes da pesquisa, as coordenadoras e os professores, concordam quanto ao papel de liderança a ser assumido por esse profissional, principalmente na articulação da formação desenvolvida no espaço escolar, e ao fazê-lo manifestam a necessidade de compreensão, reconhecimento e valorização do trabalho do coordenador pedagógico na formação do docente.

O presente estudo procurou evidenciar que a atividade do coordenador pedagógico, na formação contínua centrada na escola, é um saber-fazer multideterminado, decorrente da formação pessoal, da organização institucional e das políticas públicas. Para tanto, apoiou-se na concepção de que a coordenação pedagógica é uma atividade recente, cuja profissionalidade está em re-elaboração em função: da especificidade dessa ação, que está ancorada em diferentes sistemas de ensino, da diversidade cultural da escola e da pluralidade dos currículos de formação inicial e contínua desse profissional.

O caminho percorrido possibilitou o acesso a uma ampla bibliografia que aborda questões referentes à ação do coordenador pedagógico e à discussão atual sobre formação contínua do docente na escola. O que demonstra que este trabalho foi construído a partir da colaboração de outras investigações e reflexões as quais ajudaram a estabelecer o seu foco, constituindo-o em ponto de partida para o estudo dos dados coletados. Essa análise, por sua vez, foi sendo construída nesse período de quatro anos, por meio da contribuição dos cursos frequentados, das leituras das bibliografias garimpadas, da pesquisa empírica desenvolvida durante dois semestres letivos em duas escolas, das transcrições e análises do material coletado, das várias leituras e re-escritas que caracterizam a organização de um texto científico.

Ao se apresentarem as conclusões desse percurso investigativo, cabe a rememoração da trajetória deste trabalho que, ao partir da questão Quais limites e possibilidades $o$ coordenador pedagógico encontra e cria ao investir na organização da formação contínua 
do docente nas escolas municipais de São Paulo?, mobilizou os esforços no sentido de colher a visão de coordenadores pedagógicos sobre a formação contínua realizada no horário coletivo de três escolas municipais de São Paulo e analisá-la a partir do referencial teórico abordado. Essa decisão revelou a necessidade de compreender o contexto da criação do cargo de coordenador pedagógico. A reconstituição da história da coordenação pedagógica, descrita no Capítulo II, cujas referências principais estão em Pérez (1992), Fusari (1997), Borges (1999), Salvador (2000) e Souza (2005), possibilitou acompanhar as mudanças ocorridas, frutos das transformações econômicas e sociais que engendraram políticas públicas para essa atividade. Na Rede Municipal de Ensino de São Paulo, o cargo de coordenador pedagógico foi criado há 23 anos, um tempo curto, se comparado à história da instrução pública no Brasil. Esse aspecto, associado aos relatos nas entrevistas, revelou uma simultaneidade entre o surgimento da coordenação pedagógica no cenário educativo e a formação contínua do próprio coordenador.

Para buscar uma resposta à indagação principal deste estudo, foi preciso mergulhar nas referências teóricas que discutiam a formação contínua do docente na escola, afinal o trabalho do coordenador pedagógico está localizado nesse espaço. Assim, recorreu-se a autores como Canário (2006); Nóvoa (1992); Marcelo Garcia (1999); Libâneo (2003) e outros, o que possibilitou à pesquisadora estabelecer a complexidade desse espaço formativo.

As vozes dos coordenadores e dos professores encontraram eco na literatura, o que favoreceu desenvolver algumas considerações sobre a temática, que, por serem históricas, estão situadas no tempo e no espaço da escola brasileira do início do século XXI.

No decorrer da pesquisa, ao focar a organização e a gestão da formação contínua desenvolvida no horário coletivo, um aspecto fartamente destacado pelas coordenadoras foi a importância de suas ações profissionais no desenvolvimento da formação proposta para os horários coletivos das escolas. Na percepção delas, a existência do coordenador na escola estava diretamente associada à organização desse espaço formativo.

No entanto, não se pode analisar com ingenuidade esse dado, pois a presença do coordenador pedagógico no espaço escolar e a existência de um tempo institucional para a formação centrada na escola existem em função de uma política de formação do docente, que, normalmente, se apropria das idéias progressistas, tornando-as instrumentos de controle, por meio dos acompanhamentos externos e das avaliações institucionais. Isso revela uma perspectiva de trabalho apoiada na racionalidade técnica, generalista e massificante, que por essa razão desmonta as construções realizadas por cada escola, suas singularidades, e desconsidera os saberes elaborados pelos educadores, geralmente tratando-os como tábulas 
rasas, como técnicos que cumprem a incumbência de aplicar o plano de trabalho proposto nos documentos oficiais - "Guias de Planejamento e Orientações Didáticas" - que indicam o que fazer e o como fazer.

Assim, quando o mote da formação constitui-se em uma imposição externa, isso não só desmonta as construções formativas locais, como também nega os saberes de cada comunidade educativa.

Realizar o trabalho de formação na escola de forma crítica e reflexiva exige do coordenador a consciência dos inúmeros fatores determinantes desse trabalho e a assunção de uma posição de liderança, aspecto esse destacado como atributo da coordenação, o que implica o desafio de construir uma formação sólida, afinada com a complexidade e a diversidade das situações pedagógicas na escola. Para tanto, as formações inicial e continuada não podem estar alicerçadas numa perspectiva instrucional, baseada em prescrições e orientações, e precisam estar organizadas para ampliar as expectativas e concepções desse profissional, para que atue em qualquer situação.

Deste modo, uma formação que não promova o desenvolvimento das capacidades de refletir e re-elaborar as situações profissionais está fadada a sofrer, ainda mais com as descontinuidades das políticas públicas que, normalmente, veem no coordenador pedagógico o canal por onde fluem as determinações de suas propostas.

No entanto, os dados não deixam dúvidas. Mesmo submetidas a um cenário adverso, marcado por uma formação profissional pautada num currículo generalista, pelo ingresso em escolas com peculiaridades locais e por intervenções sistemáticas do sistema de ensino, as coordenadoras participantes desta pesquisa revelaram uma preocupação com sua própria formação e com a construção (na escola) da identidade da coordenação, o que lhes possibilitou desenvolver competências que favoreceram o acompanhamento da formação contínua dos docentes.

O discurso da escola como locus de formação docente ultrapassou as fronteiras acadêmicas e foi incorporado pelas políticas públicas educacionais, tornando-se, como alerta Marcelo Garcia (1999), “lugar-comum”. Contudo, os depoimentos nas entrevistas ratificaram a importância desse espaço de formação para o desenvolvimento da profissionalidade docente, para a organização dos projetos de cada unidade e para consolidação da concepção do professor como profissional crítico, reflexivo e pesquisador de sua prática.

Em seus depoimentos, as coordenadoras ajudaram a evidenciar que a formação na escola é uma ação complexa, marcada pelas negociações possíveis entre coordenadores, sistema de ensino e docentes, esses últimos pela participação na concepção, na estruturação e 
na avaliação dos projetos formativos. Mas elas mostraram também que as determinações dos organismos superiores do sistema educativo têm minado essa possibilidade pela imposição dos projetos de formação formulados pelos órgãos centrais do governo. Desta forma, não é demasiado afirmar que uma boa parte das atividades de formação coordenadas por essas profissionais está muito mais pautada por uma lógica funcional e instrumental do que por uma perspectiva crítica e de construção da autonomia docente. Pôde-se perceber que a coordenação pedagógica e a escola como locus de formação do professor foram instituídas num contexto epistemológico de contradição entre uma ideia de protagonismo dos sujeitos aprendentes e de subordinação às concepções oficias.

A formação centrada na escola expõe a pessoa do coordenador como gestor desse espaço formativo e o principal responsável pela valorização dos conhecimentos docentes e pela construção do coletivo escolar. Ao horário coletivo (JEIF), quando organizado a partir das necessidades locais configuradas em um projeto construído pela equipe escolar (PPP), foi atribuído um papel estratégico na formação contínua do docente, uma vez que, por meio da interlocução coletiva, promove a reflexão das ações educativas desenvolvidas ou a serem desenvolvidas na escola, possibilitando, assim, a construção de um trabalho pedagógico disciplinado pelas necessidades da realidade escolar.

Deste ponto de vista, considera-se também que a formação contínua dos coordenadores precisa estar estruturada em espaços de estudos, de reflexão e de troca de experiências sobre questões que realmente os incomodem como formadores que são de professores no espaço de ação e de análise que é a escola.

Levando em conta os dados estudados, esse último exame sugere que as experiências formativas, profissionais e conceituais vivenciadas pelo coordenador pedagógico na sua trajetória pessoal e profissional influem na ação de formação do docente na escola e podem causar empecilhos ou favorecer ao desenvolvimento de uma formação que visa à constituição do sujeito docente autônomo e crítico, capaz de tomar decisões assertivas sobre os encaminhamentos pedagógicos, visando à aprendizagem dos alunos.

Os impedimentos localizados estão, normalmente, relacionados a alguns pontos: o primeiro diz respeito a uma deficiência na formação inicial do coordenador, que gera, principalmente no início da profissão, uma insegurança e uma tensão no enfrentamento das demandas da formação do docente; o segundo é referente à pressão que o coordenador sofre tanto pela equipe escolar e suas demandas imediatas, quanto pelas determinações oficiais medidas pelas avaliações institucionais; o terceiro ponto é concernente à formação oferecida ao coordenador pelo sistema, que tem a intenção de se tornar o elemento central na discussão 
na escola; e o quarto ponto diz respeito à posição assumida pelo coordenador no desenvolvimento da formação, suas concepções educativas, seu modo de ver e compreender as relações na sociedade. Tais situações, que precisam ser alvo de reflexão, não podem caracterizar-se como determinantes do trabalho desenvolvido pelo coordenador, principalmente na formação dos professores, pois, desta forma, corre-se o risco de um trabalho pautado pela reprodução e não pela reflexão sobre os saberes e fazeres pedagógicos e sobre as verdades instituídas a respeito do professor e da ação pedagógica.

A intersecção entre esses elementos constitui desafios ao coordenador na articulação da formação centrada na escola. Para superá-los, de modo a desenvolver uma consciência crítica sobre sua atividade profissional, o coordenador necessitará reposicionar seu ofício na contramão dessa história. Isso significa, como destacado pelas coordenadoras entrevistadas, investir:

- Na construção da formação centrada na escola, como uma modalidade que tem por base a relação entre o fazer e a reflexão crítica sobre o mesmo (sem deixar que isso caia apenas na socialização de novos fazeres);

- No trabalho com os problemas reais da escola (o que requer uma competência para identificá-los coletivamente);

- No desenvolvimento de uma equipe envolvida nos projetos da escola;

- No investimento na formação contínua ao longo do exercício profissional;

- No exercício da reflexão crítica sobre o seu próprio fazer;

- No reconhecimento dos professores como profissionais detentores de saberes, mesmo que sejam saberes práticos;

- $\mathrm{Na}$ busca por parcerias que assegurem às propostas formativas da unidade a participação da direção e da supervisão;

- Na ousadia substantiva da inovação, da reinvenção das concepções e dos fazeres, da criação como aspecto fundamental nos projetos formativos, na postura a ser desenvolvida e na atividade do coordenador.

Identificados alguns caminhos para o trabalho dos coordenadores pedagógicos, os dados da pesquisa ensejam a conclusão de que as possibilidades de uma prática emancipadora da coordenação pedagógica estão associadas, principalmente, ao uso que se faz da relativa autonomia da escola, o que aponta como limite dessa prática o modo como a unidade lida 
com as imposições de projetos externos, uma vez que nesses casos a escola não é consultada e nem considerada em suas construções epistemológicas.

Das situações investigadas verificou-se que os professores destacam o coordenador como articulador da formação e aceitam a socialização dos programas e projetos oficiais como produto das pressões e cobranças sofridas por esse profissional. Tal processo interfere na subjetividade dos participantes e na elaboração de um coletivo autodeterminado. Decorre daí uma ponderação desalentadora em relação a um trabalho de formação emancipador, pois nessa perspectiva os profissionais tornam-se submissos à orientação externa, incapazes de críticas consistentes e de formulação de projetos próprios. Essa situação é sintomática da necessidade do domínio do coordenador sobre o tempo de trabalho e de uma regulação da formação que se caracterize pela autonomia das escolas na proposição e na elaboração de seus projetos formativos.

No que refere ao espaço escolar, não é demasiado afirmá-lo como local de múltiplas interferências, o que significa que subsiste como uma 'cultura local' em virtude da tradução que se faz, em cada escola, das políticas públicas e da imprevisibilidade da ação educativa.

Conforme foi demonstrado nesta pesquisa, a formação centrada na escola, sob a articulação do coordenador pedagógico, por um lado, está submetida ao controle do estado, à política interna da organização escolar e às relações de poder estabelecidas nesse enredamento. Por outro lado, sofre influência das concepções educativas desses profissionais que determinam suas opções de formação. Portanto, se o que prevalecer for uma dimensão instrumental, a formação estará focada numa organização metodológica, como fim e não como meio de mudança na prática educativa do docente. Essa estrutura pressupõe a quantificação dos resultados e está pouco voltada à reflexão crítica sobre o fazer situado.

Nesta perspectiva, é possível ratificar o que estabelecemos como hipótese, ou seja, os limites e as possibilidades da gestão da coordenação pedagógica, na escola pública municipal, estão relacionados à natureza pessoal dos coordenadores, à política pública relativa à educação, seus objetivos e compromissos, à cultura escolar e às características do grupo com que deverá trabalhar. É nesta articulação que se equilibram os limites entre um trabalho centrado na escola e na pessoa do professor, mediado por um profissional crítico, ou numa atividade elaborada a partir da concepção de que os professores não conhecem seu ofício e precisam ser ensinados pelo coordenador.

Aponta também, como possibilidade de uma ação mais autônoma, para uma gestão comprometida com a geração de mudanças qualitativas no espaço pedagógico. Para isso é necessário que o trabalho da direção e da coordenação não esteja descolado de um projeto de 
escola comprometido com o enfrentamento dos problemas pedagógicos e com a construção do trabalho coletivo, tendo como meta a oferta de um ensino de qualidade para todos.

Em que pesem as diferentes concepções e os modos diversos da condução do desenvolvimento da formação na escola, as coordenadoras pedagógicas entrevistadas, se autodeterminaram responsáveis pela formação docente centrada na escola, assumindo o discurso que considera esse espaço como locus de formação. Porém, denunciaram a necessidade de empregar esforços na construção de uma identidade formativa que possibilite legitimar, junto às equipes escolares e ao sistema, uma liderança pautada na adequação do tempo às tarefas da coordenação e na compreensão do papel do coordenador pedagógico não como técnico, mas como um pesquisador do seu fazer, numa perspectiva reflexiva e crítica.

A formação dos profissionais de educação vem de alguma forma marcada por uma história do consenso, da oposição aos conflitos e às resistências, e a atuação profissional, não poderia ser diferente, vem sendo construída sob uma lógica racionalizadora que investe pouco nos educadores, contudo mede a eficiência das atuações por padrões quantitativos que desconsideram a qualidade das relações no processo de humanização que caracteriza a educação. O discurso uniformizante desse tipo de administração não deixa espaço para que os sujeitos pensem, re-elaborem e criem em função de suas dificuldades e diferenças, nem mesmo consideram que os profissionais tenham saberes e competências pré-estabelecidas antes de qualquer interferência formativa oferecida por esse sistema. Os coordenadores também estão implicados nessa história e sua ação decorrente das posições assumidas, então ou se conformam com essa racionalização e assumem um papel burocrático, muitas vezes já atribuído a eles, ou recusam esse enredo, que não responde a uma ideia de formação de educadores que extrapole o fazer técnico e se revista do protagonismo de quem elabora coletivamente os próprios projetos formativos.

Retoma-se aqui a epígrafe inicial. Não se trata de uma supervalorização de um personagem em detrimento dos outros, pois, como foi reforçado pelas coordenadoras entrevistadas, o projeto educativo de uma escola é (deve ser) uma construção coletiva. Porém, nesse momento em que as políticas públicas estabelecem de modo exacerbado que o sentido dessa função deve estar ligado à formação do professor na escola, é importante rever o papel desse profissional, para que a luta pela superação de uma identidade difusa, enredada pelo sistema, não produza um afastamento entre a formação proposta na escola e os projetos formativos coletivos e pessoais dos docentes.

Conhecer essas escolas e seus coordenadores foi importante não só para reforçar o papel fundamental do coordenador pedagógico na condução da formação contínua do docente na escola, mas sobretudo para entendê-lo como um processo de conquista de um território 
próprio $^{67}$, cujas fronteiras estão sendo constantemente negociadas, quer por limitações da organização escolar, quer por marcos decorrentes das políticas públicas, quer pelas transformações pessoais e profissionais a que todo educador está sujeito. A pesquisa, também, permitiu confirmar que é possível trabalhar por uma educação de qualidade para todos quando a equipe pedagógica reveste-se de um projeto comprometido com a transformação da sociedade e trabalha no espaço escolar para concretizá-lo.

Finalizando, reafirma-se a idéia de que esse trabalho não tem a pretensão de constituir-se em resposta para todas as questões acerca do coordenador e da formação contínua na escola. Como toda pesquisa, ela tem as limitações próprias de suas fronteiras. Portanto, espera ser mobilizadora de novas pesquisas e de novos conhecimentos. 


\section{REFERÊNCIAS BIBLIOGRÁFICAS}

ALARCÃO, I. Formação continuada como instrumento de profissionalização docente. In: VEIGA, I. P. (org.). Caminhos da profissionalização do magistério. Campinas: Papirus, 1998.

. (Org.). Escola reflexiva e nova racionalidade. Porto Alegre: Artmed, 2001.

ALMEIDA, M. I, de. O sindicato como instância formadora dos professores: novas contribuições ao desenvolvimento profissional. 1999. Tese (doutorado). Faculdade de Educação da Universidade de São Paulo, São Paulo, 1999.

.Formação contínua de professores. In: BRASIL - MEC - SALTO PARA O FUTUTO.

TV ESCOLA. Formação contínua de professores. Boletim 12, agosto, 2005.

ANDRÈ, M. E. D. A; LÜDKE, M. Pesquisa em Educação: abordagens qualitativas. São Paulo: EPU, 1986.

. Os professores(as) diante das mudanças educacionais. In: BICUDO, M. A.; SILVA JUNIOR, C. A. (orgs.). Formação do educador e avaliação educacional. São Paulo: UNESP, 1999, p. 249-261.

A pesquisa no cotidiano escolar. In FAZENDA, I. (org). Metodologia da pesquisa educacional. São Paulo: Cortez, 1994.

ARCHANGELO, A. O coordenador pedagógico e o entendimento da instituição. In PLACO, V. M. N. de S.; ALMEID, L. R. O coordenador pedagógico e o cotidiano da escola. São Paulo: Edições Loyola, 2005, p. 135 a 143. 
AZANHA, J. M. P. Proposta pedagógica e autonomia da escola. In AZANHA, J. M. P. A formação do professor e outros escritos. São Paulo: Editora Senac São Paulo, 2006. p. 87 a 104.

APEOSP. O trabalho do coordenador pedagógico: um caminho metodológico. Caderno de formação n.1, São Paulo, agosto, 1996.

BARROS, C. O. T. O papel do diretor escolar na formação em serviço: um estudo da proposta de formação da Secretaria Municipal de Educação de São Bernardo do Campo. 2004, 155 f. Dissertação (mestrado) Faculdade de Educação, Universidade de São Paulo, São Paulo, 2004.

BARROSO, João. Formação, Projecto e Desenvolvimento Organizacional. In CANÁRIO, Rui (org). Formação e situações de trabalho. Porto: Porto Editora, 2003. p. 61 a 78.

(et. all). A formação de professores e a mudança organizacional das escolas. In FERREIRA, N. S. C. Formação Continuada e gestão da educação. São Paulo: Editora Cortez, 2006. p. 117 a 143.

BLANDINO, F. M. L. A construção da identidade da coordenadora pedagógica rumo a um projeto de escola: o ideal, o legal e o real. 1996, ? f. Dissertação (mestrado). Programa de Pós- graduação da Faculdade de Educação, Universidade de São Paulo. São Paulo, 1996.

BORGES, N. M. M. A coordenação pedagógica nas escolas municipais de ensino fundamental de São Paulo. 1996, ? f. Dissertação (mestrado). Área de História e Filosofia de Educação, Pontifícia Universidade Católica de São Paulo. São Paulo, 1999.

BRUNO, E. B. G.; ALMEIDA, L. de R; CHRISTOV, L. H. da S. (orgs.). O coordenador pedagógico e a formação docente. São Paulo: Loyola, 2004.

BRUNO, E. B. G. O trabalho coletivo como espaço de formação. In GUIMARAES, A. A. (et. al. ) O coordenador pedagógico e a educação continuada. São Paulo: Editora Loyola, 2005. 
CAMPOS, M. M. M. Pesquisa participante: possibilidades para o estudo na escola. Cadernos de Pesquisa no 49. Fundação Carlos Chagas, maio 1984.

CANÁRIO, R. Gestão escolar: Como elaborar o plano de formação? Cadernos de Organização Escolar no 3. Portugal: Editor: Instituto de Inovação Educacional, 1995.

A escola: o lugar onde os professores aprendem. Aveiro:Universidade de Aveiro, 1997. (mimeo)

A escola tem futuro? Das promessas as incertezas. Porto Alegre: Artmed, 2006.

CANDAU, V. Mª Magistério construção cotidiana. Petrópolis: Editoras Vozes, 1997.

CAVACO, M. H. Ofício de professor: o tempo e as mudanças. In NÓVOA. A. (org.) Profissão professor. Porto: Porto Editora, 1995, p. 155 a 191.

CHRISTOV, L. H. da S. Sabedorias do coordenador pedagógico: enredos do interpessoal e de (con) ciências na escola. 2001, 162 f .Tese (doutorado). Departamento em Psicologia da Educação. Pontifícia Universidade Católica de São Paulo. São Paulo, 2001.

(org.). O coordenador pedagógico e a formação docente. São Paulo: Loyola, 2004.

Educação continuada: função essencial do coordenador pedagógico. In GUIMARAES, A. A. (et. al. ) O coordenador pedagógico e a educação continuada. São Paulo: Editora Loyola, 2005.

CLEMENTI, N. A voz dos outros e a nossa voz: Alguns fatores que intervêm na atuação do coordenador. In ALMEIDA, L. R. de \& PLACCO, V. M. N. de. O coordenador pedagógico e o espaço de mudança. São Paulo: Edições Loyola, 2005, p. 53 a 66.

CONTRERAS, J. A autonomia de professores. São Paulo: Cortez, 2002. 
CORTELA, M. S. A Escola e o conhecimento: fundamentos epistemológicos e políticos.

São Paulo. Editora Cortez, 2000.

CUNHA, M. I. da. Profissionalização docente: contradições e perspectivas. In VEIGA, I. P. A. e CUNHA, M. I. da. (orgs.). Desmistificando a profissão do magistério. São Paulo: Papirus, 1999.

DEMO, P. Qualidade e representatividade da pesquisa em educação. Cadernos de Pesquisa nº 55, Fundação Carlos Chagas, nov., 1985.

DOMINGUES, I. O horário de trabalho coletivo e a (re)construção da profissionalidade docente. 2004, 182 f. Dissertação (mestrado). Faculdade de Educação, Universidade de São Paulo. São Paulo, São Paulo, 2004.

Grupos dialogais: compreendendo os limites entre pesquisa e formação. In PIMENTA, S. G.; GHEDIN, E. FRANCO, M. A. S. Pesquisa em educação. Alternativas investigativas com objetos complexos. São Paulo: Edições Loyola, 2006.

ELIAS, M. D. C. A questão da autoridade no desempenho da função pedagógica. 1983 ?f. Dissertação (mestrado). Programa de Pós-Graduação em Supervisão e Currículo, Universidade Católica de São Paulo. São Paulo,1983.

ESTEVES, J. M. Mudanças sociais e função docente. In: NÓVOA, A. (Org.). Profissão professor. Porto: Porto, 1999, p. 93 a 124.

FARIA FILHO, L. M. de et. al. A cultura escolar como categoria de análise e como campo de investigação na história da educação brasileira. Revista Educação e Pesquisa, v.30, n. 01. São Paulo, 2004. p.139-159.

FOUCAULT, M. Microfísica do poder. Rio de Janeiro: Graal, 1979. 
FRANCO, $\mathrm{M}^{\mathrm{a}}$ A. S. A metodologia de pesquisa educacional como construtora da práxis investigativa. In Nuances, estudos sobre Educação. Ano 9, v. 9, nº 9 e 10, jan/jun/jul/dez, São Paulo: UNESP-Presidente Prudente, 2003.

FRANCO, M ${ }^{\text {a }}$. A. S. Coordenação pedagógica: uma práxis em busca de sua identidade educativa. Goiana, Revista do Departamento de Educação, UCG, nº 1, p.125-138, jan/jul. 2005.

FRANCO, Ma ${ }^{a}$ A. S. A práxis pedagógica como instrumento de transformação da prática docente. In Anais da 28 ${ }^{a}$ Reunião Anual da ANPED. Caxambu, Minas Gerais, 2005.

FRANCO, A. P. A. A profissionalização do Supervisor de Ensino da Rede Estadual Paulista: interfaces com os fazeres escolares. 2007, 215 f. Dissertação (mestrado). Faculdade de Educação, Universidade de São Paulo. São Paulo, 2007.

FREITAS, D. N. T. A gestão educacional na interseção das políticas federal e municipal. Revista da Faculdade de Educação. São Paulo. v. 24, n.2, p.29-50, 1998.

FULLAN, M.; HARGREAVES, A. A escola como organização aprendente: buscando uma educação de qualidade. Porto Alegre: ArtMed, 2000.

FUSARI, J. C. A educação do educador em serviço: treinamento de professores em questão. São Paulo. 1988, ? f. Dissertação (mestrado). Pontifícia Universidade Católica de São Paulo (PUC - SP). São Paulo, 1988.

Formação contínua de educadores: um estudo de representações de coordenadores pedagógicos da Secretaria Municipal de Educação de São Paulo (SMESP). 1997, 201 f .Tese (doutorado). Faculdade de educação, Universidade de São Paulo. São Paulo, 1997.

Avaliação de modalidades convencionais e alternativas de educação contínua de educadores: preocupações a serem consideradas. In BICUDO, M. A. \& SILVA JR, C. A. (orgs.). Formação do educador e avaliação educacional. São Paulo: UNESP, 1999, p.221 a 224. 
e FRANCO, A. P. Formação contínua em serviço e projeto pedagógico: uma articulação necessária. In: BRASIL - MEC - SALTO PARA O FUTUTO. TV ESCOLA. Formação contínua de professores. Boletim 12, agosto, 2005, p. 21 a 27.

. Formação contínua de educadores na escola e em outras situações. In BRUNO, E. B. G. e ALMEIDA, L. de R, CHRISTOV, L. H. da S. (orgs.). O coordenador pedagógico e a formação docente. São Paulo: Loyola, 2007, p. 17 a 24.

GARCIA, M. Coordenação pedagógica: ação, interação, transformação. 1995, 134 f. Dissertação (Mestrado) Programa de Pós-Graduação em educação. Pontifícia Universidade Católica de São Paulo, São Paulo. São Paulo, 1995.

GARCIA, O. G. Direção e coordenação pedagógica inspiradas na Educação Libertadora: propiciadoras da construção de um ambiente escolar mais significativo e humanizado. In Revista de Educação AEC. Educação Libertadora Participando da Luta Social. Brasília, v. 26, no 105, out/dez, p. 121 a 129, 1997.

A formação contínua de professores HTPC: alternativas entre as concepções instrumental e crítica). 2003, 156 f. Tese (doutorado) Programa de Pós-Graduação em Psicologia da Educação, Pontifícia Universidade Católica de São Paulo, São Paulo. 2003.

Pela ótica do PROVE, qual o lugar da coordenação pedagógica na formação do professor / professora na escola? In Revista Prove 10 anos, 1997-2007. Editora Páginas e Letras. São Paulo, p. 55 a 61, 2007.

GARRIDO, E. Espaço de formação contínua para o professor-coordenador. In BRUNO, E. B. G. e ALMEIDA, L. de R.; CHRISTOV, L. H. da S. (orgs.). O coordenador pedagógico e a formação docente. São Paulo: Loyola, 2007, p. 9 a 15.

GATTI. B. A. A construção da pesquisa em educação no Brasil. Brasília: Plano Editora, 2002.

GHEDIN, E.; ALMEIDA, M. I.; LEITE, Y.U.F. Formação de professores: caminhos e descaminhos da prática. Brasília: Líber Livro Editora, 2008. 
GHEDIN, E.; FRANCO, M. A . S. Questões de método na construção da pesquisa em educação. São Paulo: Cortez, 2008.

GIROUX, A. H. Os professores como intelectuais: Rumo a uma pedagogia crítica da aprendizagem. Porto Alegre: Artes Médicas, 1997.

GOMES, M. de O.; LIMA, M. do S. L. Redimensionando o papel dos profissionais da educação: algumas considerações. In: PIMENTA S. G.; GHEDIN, E. (orgs.). Professor reflexivo no Brasil: gênese e crítica de um conceito. São Paulo: Cortez, 2002, p. 163 a 186.

GUIMARAES, V. S. A socialização profissional e profissionalização docente - Um estudo a partir do professor recém-ingresso na profissão. 2006. (mimeo)

IMBERNÓN, F. Formação docente e profissional. Formar-se para a mudança e incerteza. São Paulo: Cortez, 2001.

LERNER, D. É possível ler na escola? Porto Alegre: Artmed, 2000.

LIBÂNEO, J. C. Que destino os educadores darão à pedagogia. In PIMENTA, S. G. (org) Pedagogia ciência da educação? São Paulo: Cortez, 1996, p. 107 a 134.

- Ainda as perguntas: o que é pedagogia, quem é o pedagogo, o que deve ser o curso de pedagogia. In PIMENTA. S. G. (org.). Pedagogia e pedagogos: Caminhos e perspectivas. São Paulo: Cortez, 2002. p. 59 a 97.

Organização e gestão da escola: teoria e prática. Goiânia: Alternativa. 2003.

LUCAS, J. G. A teoria na formação do educador: análise dos grupos de formação permanente de professores da Secretaria Municipal de Educação de São Paulo. 1992, ? f. Dissertação (mestrado). Programa de Pós-Graduação em filosofia e historia da educação, Pontifícia Universidade Católica de São Paulo. São Paulo.1992. 
MARCELO GARCIA, C. Formação de professores: para uma mudança educativa. Porto: Porto Editora, 1999.

MARIN, A. J. Desenvolvimento profissional docente: Inicio de um processo centrado na escola. In VEIGA, I. P. (org.). Caminhos da profissionalização do magistério. Campinas: Papirus, 1998.

MARTINS, H. H. T. de. Metodologia qualitativa de pesquisa. Revista Educação e Pesquisa. São Paulo, v.30, n. 02, p.289-300, 2004.

MATE, C. H. O coordenador pedagógico e as reformas pedagógicas. Formação contínua de educadores na escola e em outras situações. In BRUNO, E. B. G.; ALMEIDA, L. de R,. O coordenador pedagógico e a formação docente. São Paulo: Loyola, 2004, p. 71 a 76.

. Qual a identidade do professor coordenador pedagógico? In GUIMARAES. A. A. (et. al.) $\mathbf{O}$ coordenador pedagógico e a educação continuada. São Paulo: Edições Loyola, 2005 , p. 17 a 20.

MOITA, Maria da Conceição. Percursos de formação e de Trans-formação. In NOVOA, António (org.). Vidas de Professores. Porto: Porto Editora, 1992, p. 111 a 139

NÓVOA, A. Formação de professores e profissão docente. In: NÓVOA, A. (org.). Os professores e a sua formação. Lisboa: Dom Quixote, 1992, p. 15-33.

Os professores na virada do milênio: do excesso dos discursos à pobreza das práticas. Pesquisa e Educação, São Paulo. v. 25, no 1, jan./jun, p 11-20, 1999.

Professor se forma na escola. Revista Nova Escola. Ano XVI, n 14, maio, 2001.

A formação contínua entre a pessoa-professor e a organização-escola. In NÓVOA, A Formação de professores e trabalho pedagógico. Lisboa: Educa, 2002, p.33 a 48. 
e FRANCO, A. P. Formação contínua em serviço e projeto pedagógico: uma articulação necessária. In: BRASIL - MEC - SALTO PARA O FUTUTO. TV ESCOLA. Formação contínua de professores. Boletim 12, agosto, 2005, p. 21 a 27.

NUNES, C. do S. C. Os sentidos da formação contínua. O mundo do trabalho e a formação de professores no Brasil. Tese. (doutorado), 2000, ?f. Programa de Pós-Graduação em Educação, Universidade de Campinas, São Paulo, 2000.

NUNES, J. B. C. O processo de socialização na profissão docente. Universidade Estadual do Ceará. 2002. (mimeo)

OLIVEIRA-FOMOSINHO, J. Um capítulo metodológico: os estudos de caso. In KISHIMOTO, T. (orgs). Formação e contexto: uma estratégia de integração. São Paulo. Pioneira Thomson Learning, 2002, p. 89 a 108.

ORSOLON. L. A. M. O coordenador/formador como um dos agentes de transformação da/na escola. In ALMEIDA, L. R. de \& PLACCO, V. M. N. de. O coordenador pedagógico e o espaço de mudança. Edições Loyola. São Paulo, 2005, p. 17 a 26.

PEREIRA, E. M. de A. Professor como pesquisador: o enfoque da pesquisa-ação na prática docente. In GERALDI, C. M. G. (orgs.) Cartografia do trabalho docente. Campinas: Mercado das Letras, 1998, p. 105 a 134.

PÉREZ. M. A. G. O papel do coordenador pedagógico nas escolas da Rede Municipal de Educação da cidade de São Paulo: expectativas e opiniões dos professores de $5^{\mathrm{a}}$. à $8^{\mathrm{a}}$. séries. 1992, ?f. Dissertação (mestrado). Faculdade de Educação, Universidade de São Paulo. São Paulo, 1992.

PÉREZ GÓMES, A. I. A cultura escolar na sociedade neoliberal. Porto Alegre: ArtMed, 2001.

PIMENTA, S. G. Formação de professores: os saberes da docência e a identidade do professor. Revista da Faculdade da Educação. São Paulo. V. 22 n², jul/dez, 1996, p.72-88. 
Projeto pedagógico e identidade da escola. Transcrição da palestra proferida no Congresso de Educação Continuada - Pólo 7, Taubaté/SP, setembro de 1998.

. O pedagogo na escola pública. São Paulo: Edições Loyola, 2002a

; GHEDIN, E. (orgs.). Professor reflexivo no Brasil: gênese e crítica de um conceito.

São Paulo: Cortez, 2002 b.

. Formação de Professores: identidade e saberes da docência. In PIMENTA, S. G. (org). Saberes pedagógicos e atividade docente. São Paulo. Cortez. 2005, p. 15 a 34.

PINTO, U. de. A Pedagogia e pedagogos escolares. 2006, 173 f. Tese (doutorado). Programa de Pós-Graduação em Educação, Universidade de São Paulo. São Paulo, 2006.

RODRIGUES, S. de F. P. Práticas de formação contínua em mato Grosso - da autonomia professoral à prescrição da política estatal. 2004, 247 f. Tese (doutorado). Programa de estudos Pós-Graduados em Educação: História, Política e Sociedade. Pontifícia Universidade Católica de São Paulo. São Paulo, 2004.

ROGÉRIO, R. M. F. Caminhos de professoras: o desenvolvimento profissional docente nos anos inicias do ensino fundamental. 2008, 195 f. Dissertação (mestrado). Programa de Pós-graduação em Educação, Universidade de São Paulo. São Paulo, 2008.

SACRISTÁN, J. G. Consciência e ação sobre a prática como libertação dos professores. In: NOVOA, A. (org) Profissão professor. Porto: Porto Editora,1995, p. 63 a 92.

; PÉREZ GÓMES, A. L. Compreender e transformar o ensino. Porto Alegre: Artmed, 2000.

SALVADOR. C. M. O coordenador pedagógico na ambigüidade interdisciplinar. 2000, 196 f. Dissertação (mestrado). Programa de Pós-Graduação em Educação, Pontifícia Universidade Católica de São Paulo. São Paulo, 2000. 
SANTOS. A. B. Formação continuada de professores em serviço: tentativas, avanços e recuos na busca de práticas cooperativas durante o HTPC. 2000, 145 f. Dissertação (mestrado). Programa de Pós-Graduação da Faculdade de Educação, Universidade de São Paulo. São Paulo, 2000

SANTOS. L. L. de C. P. Formação de professores na cultura do desempenho. Educação e Sociedade. Campinas. vol. 2, nº89, p. 1145 a 1157. Set/dez. 2004.

SAUL, A. M. Uma nova lógica para a formação do educador. In BICUDO, M. A. \& SILVA JR, C. A. (orgs.). Formação do educador. São Paulo: UNESP, 1999, p.115-143.

SCHÖN, D. Formar professores como profissionais reflexivos. In: NÓVOA, A. (org.). Os professores e sua formação. Lisboa: Dom Quixote, 1992, p.77-92.

SEVERINO, J. A. Metodologia do trabalho científico. São Paulo: Cortez, 2000.

SILVA JUNIOR, C. A. da. A escola pública como local de trabalho. São Paulo: Cortez, 1993.

SOUZA, M. V. Formação em serviço de professores da Secretaria Municipal de Educação de São Paulo: 1956-2004, gênese, transformações e desafios. 2005, 253 f. Dissertação (mestrado). Programa de Pós-Graduação em Educação, Universidade de São Paulo. São Paulo, 2005.

SZYMANSKI, H. (Org.). A entrevista na pesquisa em educação: a prática reflexiva. Brasília: Liber Livro Editora, 2004. (Série Pesquisa em Educação, 4)

TRAGTENBERG, M. Relações de poder na escola. Educação e Sociedade, São Paulo (0): p. 40-45, jan./abril 1985.

TOMASI, L de. WARDE, M. J., HADAD, S. (org.). O Banco Mundial e as políticas educacionais. São Paulo: Cortez, 2000. 
TORRES, R. M. Tendências da Formação Docente nos Anos 90. In WARDE, Miriam Jorge (org.) Novas Políticas Educacionais: críticas e Perspectivas. São Paulo, Programa de Estudos Pós-graduados em Educação: Historia e Filosofia da Educação, Pontifícia Universidade Católica de São Paulo, 1998.

VIANA, A. B. B. A. O papel do coordenador pedagógico na formação continuada de professores em serviço na educação de jovens e adultos. 2001, ?f. Dissertação (mestrado). Programa de Pós-Graduação em Educação, Universidade de São Paulo. São Paulo, 2001.

VIEIRA, M. M. de S. Mudança e sentimento: o coordenador pedagógico e os sentimentos dos professores. 2002, ?f. Dissertação (mestrado). Programa de Pós-Graduação em Educação, Pontifícia Universidade Católica de São Paulo. São Paulo, 2002.

WOODS, P. Investigar a Arte de Ensinar. Porto: Porto Editora, 1996.

\section{DOCUMENTOS OFICIAIS E LEGAIS}

BRASIL. Congresso Nacional. Lei de Diretrizes e Bases da Educação Nacional - 5692/71, de 20 de dezembro, 1971.

BRASIL. Congresso Nacional. Lei de Diretrizes e Bases da Educação Nacional - 9394/96, de 20 de dezembro, 1996.

SÃO PAULO. (Capital). Secretaria Municipal de Educação. Decreto-Lei no 430 de 1947. Cria a Secretaria de Higiene e Secretaria de Educação e Cultura.

SÃO PAULO. (Capital). Secretaria Municipal de Educação. Decreto-Lei no 3.069 de 1956. Criação do grupo escolar do Jaçanã, o primeiro grupo municipal de Ensino primário.

SÃO PAULO. (Capital). Secretaria Municipal de Educação. Decreto-Lei n no 3.185 de 1956. Institui o Sistema Escolar Municipal.

SÃO PAULO. (Estado) Secretaria Estadual de Educação. Lei Estadual n ${ }^{\circ}$ 201/78 de novembro de 1978. Estatuto do Magistério Público do Estado de São Paulo. 
SÃO PAULO. (Estado). Secretaria Estadual de Educação. Decreto n ${ }^{\circ} 28.170$ de 1988. Instituí a Jornada Única e o Horário de Trabalho Pedagógico no Estado de São Paulo.

SÃO PAULO. (Capital) Secretaria Municipal de Educação. Lei Municipal no 11.229 de junho de 1992. Estatuto do Magistério Público Municipal de São Paulo.

SÃO PAULO. (Capital) Secretaria Municipal de Educação. Lei Municipal no 11.434 de novembro de 1993. Dispõe sobre a Organização dos Quadros dos Profissionais da Educação na prefeitura de São Paulo.

SÃO PAULO. (Capital). Secretaria Municipal de Educação. Decreto nº 33.991 de 1994. Dispõe sobre as atribuições do coordenador pedagógico e da outras providências.

SÃO PAULO. (Capital). Secretaria Municipal de Educação. Portaria no 2083 de abril de 1994. Dispõe sobre Projetos Especiais de Ação e da outras providências

SÃO PAULO. (Capital). Secretaria Municipal de Educação. Portaria ${ }^{\circ} 3826$ de julho de 1997. Dispõe sobre Projetos Especiais de Ação e da outras providências

SÃO PAULO. (Capital). Secretaria Municipal de Educação.Caderno Educ Ação nº 2, 2001

SÃO PAULO. (Capital). Secretaria Municipal de Educação. Portaria no 1654 de março de 2004. Dispõe sobre Projetos Especiais de Ação e da outras providências

SÃO PAULO. (Capital). Secretaria Municipal de Educação. Portaria no 654 de março de 2006. Dispõe sobre Projetos Especiais de Ação e da outras providências

SÃO PAULO. (Capital). Secretaria Municipal de Educação. Portaria nº 4.057 de outubro de 2006. Dispõe sobre Projetos Especiais de Ação e da outras providências

SÃO PAULO. (Capital) Secretaria Municipal de Educação. $\underline{\text { Referencial de expectativas para o }}$ desenvolvimento da competência leitora e escritora no Ciclo II do Ensino Fundamental. SME / DOT, $2006 \underline{\text { Caderno de orientação didática de Ciências Naturais }}$ 
SÃO PAULO. (Capital) Secretaria Municipal de Educação. Referencial de expectativas para o desenvolvimento da competência leitora e escritora no Ciclo II do Ensino Fundamental. SME / DOT, 2006 Caderno de orientação didática de Língua Portuguesa

SÃO PAULO. (Capital) Secretaria Municipal de Educação. Referencial de expectativas para o desenvolvimento da competência leitora e escritora no Ciclo II do Ensino Fundamental. SME / DOT, 2006. Caderno de orientação didática de Artes

SÃO PAULO. (Capital) Secretaria Municipal de Educação. Referencial de expectativas para o desenvolvimento da competência leitora e escritora no Ciclo II do Ensino Fundamental. SME / DOT, 2006.Caderno de orientação didática de História.

SÃO PAULO. (Capital) Secretaria Municipal de Educação. Referencial de expectativas para o desenvolvimento da competência leitora e escritora no Ciclo II do Ensino Fundamental. SME / DOT, 2006. Caderno de orientação didática de física

SÃO PAULO. (Capital) Secretaria Municipal de Educação. Referencial de expectativas para o desenvolvimento da competência leitora e escritora no Ciclo II do Ensino Fundamental. SME / DOT, 2006. Caderno de orientação didática de Matemática

SÃO PAULO. (Capital) Secretaria Municipal de Educação. Referencial de expectativas para o desenvolvimento da competência leitora e escritora no Ciclo II do Ensino Fundamental. SME / DOT, 2006

SÃO PAULO. (Capital) Secretaria Municipal de Educação. Projeto Toda Força ao $1^{\circ}$ Ano: guia para o planejamento do professor alfabetizador - orientações para o planejamento e avaliação do trabalho com o $1^{\circ}$ ano do Ensino Fundamental - Ciclo I (v.1). SME / DOT, 2006.

SÃO PAULO. (Capital) Secretaria Municipal de Educação. Projeto Toda Força ao $1^{\circ}$ Ano: guia para o planejamento do professor alfabetizador - orientações para o planejamento e avaliação do trabalho com o $1^{\circ}$ ano do Ensino Fundamental - Ciclo I (v.2). SME / DOT, 2006.

SÃO PAULO. (Capital) Secretaria Municipal de Educação. Projeto Toda Força ao $1^{\circ}$ Ano: conversa com os pais. SME / DOT, 2006. 
SÃO PAULO. (Capital) Secretaria Municipal de Educação. Projeto Toda Força ao $1^{\circ}$ Ano: guia para o planejamento do professor alfabetizador - orientações para o planejamento e avaliação do trabalho com o $1^{\circ}$ ano do Ensino Fundamental - Ciclo I (v.3). SME / DOT, 2006.

SÃO PAULO. (Capital) Secretaria Municipal de Educação. Projeto Intensivo no Ciclo I: livro do aluno de Língua Portuguesa e Matemática para sala do PIC - $4^{\circ}$ ano - Ciclo I (v.1). SME / DOT, 2006.

SÃO PAULO. (Capital) Secretaria Municipal de Educação. Projeto Intensivo no Ciclo I: livro do aluno de língua Portuguesa e Matemática para sala do PIC - $4^{\circ}$ ano - Ciclo I (v.2) SME / DOT, 2006

SÃO PAULO. (Capital) Secretaria Municipal de Educação. Projeto Intensivo no Ciclo I: livro do aluno de língua Portuguesa e Matemática para sala do PIC - $4^{\circ}$ ano - Ciclo I (v.3). SME / DOT, 2006.

SÃO PAULO. (Capital) Secretaria Municipal de Educação. Projeto Intensivo no Ciclo I: material do professor (v.1) $4^{\circ}$ ano. SME / DOT, 2006.

SÃO PAULO. (Capital) Secretaria Municipal de Educação. Projeto Intensivo no Ciclo I: material do professor (v.2) $.4^{\circ}$ ano. SME / DOT, 2006.

SÃO PAULO. (Capital) Secretaria Municipal de Educação. Projeto Intensivo no Ciclo I: material do professor (v.3). $4^{\circ}$ ano. SME / DOT, 2006.

SÃO PAULO. (Capital) Secretaria Municipal de Educação Guia de estudo para o horário coletivo de trabalho: subsídios para os coordenadores pedagógicos.SME / DOT, 2006.

SÃO PAULO. (Capital) Secretaria Municipal de Educação. Educação Fundamental: Orientações gerais para o ensino de língua portuguesa e matemática no Ciclo I (v.1). SME / DOT, 2006. 
SÃO PAULO. (Capital) Secretaria Municipal de Educação. Caderno de orientações didáticas das Tecnologias da Educação. SME / DOT, 2006.

SÃO PAULO. (Capital) Secretaria Municipal de Educação. Lei Municipal nº14.660 de dezembro de 2007. Estatuto do Magistério Público Municipal de São Paulo.

SÃO PAULO. (Capital) Secretaria Municipal de Educação. Diretoria de orientação Técnica. A rede em rede: a formação continuada na educação infantil - fase 1. São Paulo; SME/ DOT, 2007.

SÃO PAULO. (Capital) Secretaria Municipal de Educação. Diretoria de orientação Técnica. Tempos e espaços para a infância e suas linguagens nos CEIs, creches e EMEIs da cidade de São Paulo. São Paulo; SME/ DOT, 2007.

SÃO PAULO. (Capital) Secretaria Municipal de Educação Referencial de expectativas para o desenvolvimento da competência leitora e escritora no Ciclo II do Ensino Fundamental. SME / DOT, 2007, Caderno de orientação didática de Geografia

SÃO PAULO. (Capital) Secretaria Municipal de Educação Guia de planejamento e orientações didáticas para o professor do $2^{\circ}$ ano do ciclo I - V.1. SME / DOT, 2007.

SÃO PAULO. (Capital) Secretaria Municipal de Educação. Guia de planejamento e orientações didáticas para o professor do $2^{\circ}$ ano do ciclo I - V.2. SME / DOT, 2007.

SÃO PAUlO. (Capital) Secretaria Municipal de Educação. Guia de Planejamento e orientações didáticas para o professor do $4^{\circ}$ ano - Ciclo I. Português. Matemática. SME/DOT, 2007.

SÃO PAULO. (Capital) Secretaria Municipal de Educação. Projeto Toda Força ao $1^{\circ}$ Ano: contemplando as especificidades dos alunos surdos. SME / DOT, 2007.

SÃO PAULO. (Capital) Secretaria Municipal de Educação. Projeto Intensivo no Ciclo I: $3^{\circ}$ ano - material do professor.Língua Portuguesa e Matemática. SME / DOT, 2007. 
SÃO PAULO. (Capital) Secretaria Municipal de Educação. Projeto Intensivo no Ciclo I: $3^{\circ}$ ano - material do aluno. Língua Portuguesa. Matemática. SME / DOT, 2007.

SÃO PAULO. (Capital). Secretaria Municipal de Educação. Portaria nº 1566 de março de 2008. Dispõe sobre Projetos Especiais de Ação e da outras providências. 
ANEXOS

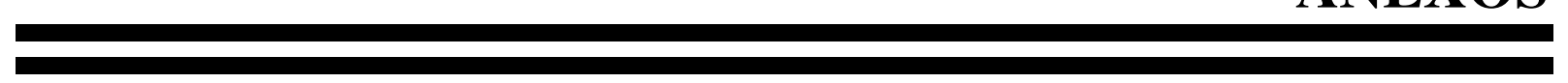


ANEXO A

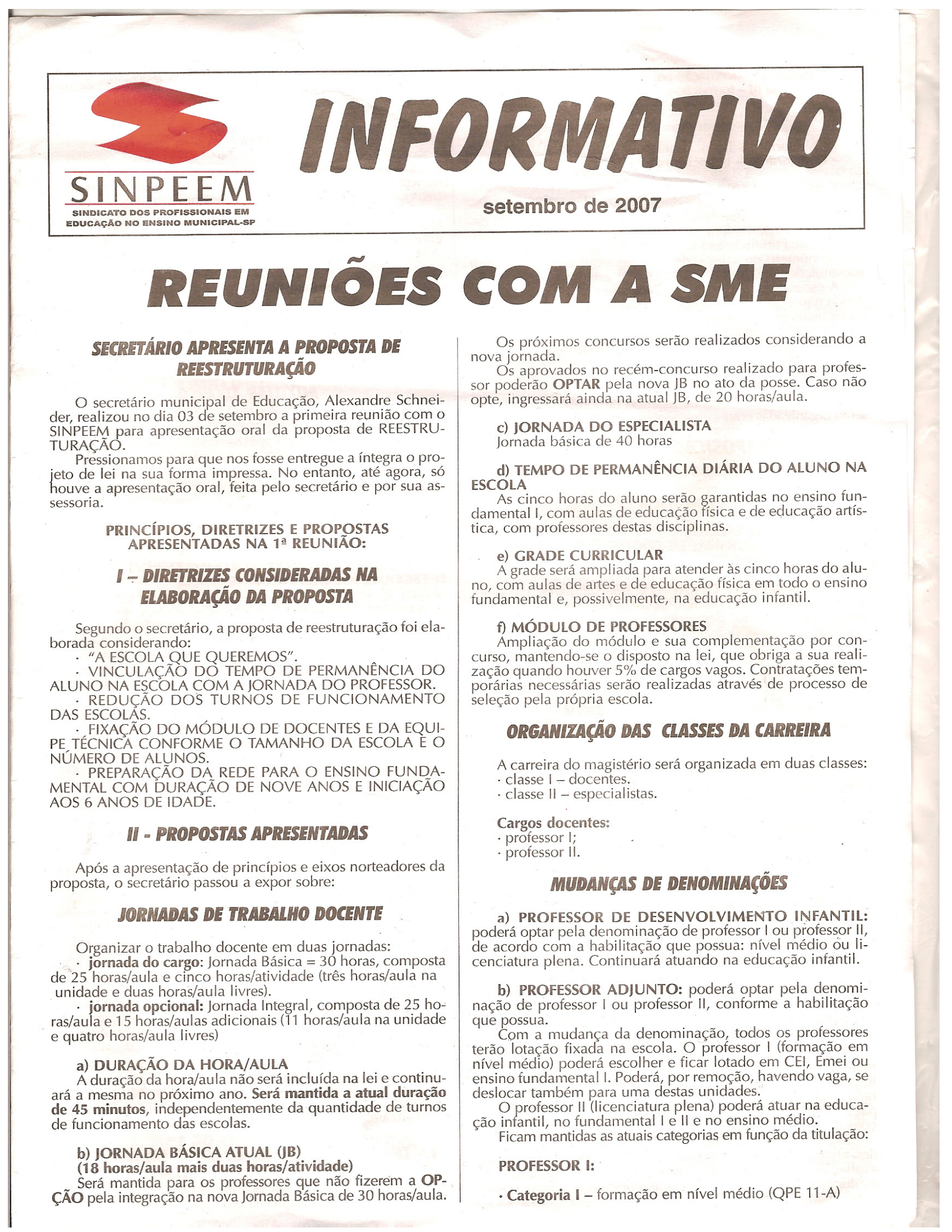


- Categoria II - formação em licenciatura curta (QPE 13-A) - Calegoria III - formaça em licenciatura plena (QPE 14-A) PROFESSOR $\|$ :

- Categoria II - licenciatura curta (QPE 13-A)

- Categoria III - licencialura plena (QPE 14-A)

\section{OBSERVAÇÖES}

Pela proposta apresentada, a partir das mudancas de de nominacóes nåo haverá mais distincōes entre tíulares e adjuntos. Cada unidade terá un módulo de professor de acordo com o número de salas e de suas necessidades, para cobri substituicöes por faltas, licencas e afastamentos.

A escola terá mais autonomia quanto à sua organizacão. Ainda não é questão fechada, mas o secreț́rio de Educaçảo os técnicos de sua equipe afirmaram que uma determinad escola, por sua decisấ, poderá dividir a quantidade de aulas existentes de um determinado componente do nivel II, por exemplo, em número igual entre os professores da unidade

Exemplo: uma unidade com quatro profoscoms de Matematica, com um total de 80 aulas, poderá distribuir 20 horas/aula para cada. As cinco horas de reqencia de jornada de cada um serăo organizadas entre substituiçōes e projetos da unidade.

\section{GOMPOSICIOO DA CLASE II (especiolistus):}

- VICE-DIRETOR PEDAGÓGICO - afual coordenador pedagógico

- DIRETOR DE ESCOLA.

- TECNICO REGIONAL DE EDUCACÃO - atual supervisor escolar.

Na proposta da SME, o cargo de coordenador pedagógico será transformado, por OPCAO dos atuais titulares, en vicediretor pedagógico. O módulo atual de coondenadores (vicediretor pedagogico), dependendo da unidade, poderá ser ampliado. A investidura neste cargo continuará ocorrendo por concursos de ingresso e de accsso.

O cargo de supervisor, igualmente por OPCÃO, terá denominação alterada para técnico regional de educaçào.

\section{FUNÇOES DE MAGSTÉMTO}

\section{VICE-DIRETOR ADMINISTRATIVO}

A proposta prevê a criação da funcão de vice-diretor administrativa, em substituição ao atual assistente de direção. Dependendo das especificidades, una unidade poderá ter dois ou três docentes nesta funcão. $O$ vice-diretor administrativo será escolhido e designado pelo diretor.

\section{POIE POSL E AUXILIAR DE DIRECÃO}

Ficam mantidas as funcões de Poie e POSL, escolhidos pelo Conselho e designados diretamente pelo diretor

A funcão de auxiliar de direcão será mantida até a criacz̃̃o do cargo de ATE III, proposto agara pelo governo, e a adocáo do novo módulo de vice-diretor administrativo.

Com a fixaçấo e complementaçåo do módulo de ATEs e designaçäo dos vice-dirctores, esta funçăo será extinta, segundo a proposta do governo.

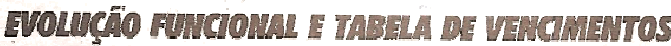

O secretário municipal de Fducação afirmou que será mantida a evoluç:ão funcional por tempo, tempo e fítulo e títulos como é hoje. Além dosses quesitos, tambem será considerada a CERTIFICACAOO PROFISSIONAL obtida pela participaça OPCIONAL do profissional de educação em avaliacooss de conhecimento.

Esta certificação poderá garantir, em funçio dos resultadós alcançados pelos que participarem voluntariamente da avaliação, pontos que farão com que o enquadramento por evolução ocorra em intervalos de tempo menor do que aquele que não participa.
No entanto, todos poderào, pelos quesitos atuais, que serão mantidos, chegar a última refercncia da tabela de vencimentos.

\section{TABELA NÄO SERÁ ALTERADA}

O secretário Schneider lambém afirmou que a proposta de REESTRUTURACÃO não mudará as tabelas de vencimen tos, que continuarão com a mesma amplitude, níveis e graus. Serão mantidas as letras A, B, C D e, E organizadas com todas as referencias (números) e diferença percentual de $6,5 \%$ entre elas.

\section{PERA DE LOTACIO POR AFSTMMENTOS}

Na proposta apresentada, as readaptaços remporârias a parír da segunda readaptação, os afastamentos sindicais, os alastamentos sem vencimentos (LIP) e os afastamentos para a prestação de serviços em comissão implicaräo na perda de lotação.

\section{MUWLUR TÉCNRO}

Ficam mantidos os cargos de ATE I e ll e cria-se o ATE III. As funcões administrativas e de secretaria poderão ser exercidas por ocupantes de qualquer um destes cargos, por decisão da escola.

O cargo de secretário será funçào gratificada e por desiga nação.

\section{QUAORO OE APOHO}

TERCEIRIZACÃO E EXTINCAOO DO CARGO DE AGENTE ESCOLAR NA VACANCIA

O secretário municipal de Educacão afirmou que o governo dará continuidade à política de terceirizacão dos senvicos de merenda, manutenção, conservação, limpeza e vigilância.

O governo nåo pretende realizar concurso para agente escolar, conforme exigido pelo SINPEEM. Afirma que os atuais agentes escolares serăo mantidos e os cargos serão extintos quando vagarem.

\section{SEM REAJUSTE SALARIAL E INCORPORAÇ̃̃O}

Não há incorporação das gratificaçōes aos padrōes de vencimentos na proposta apresentada. Não foi também anunciado qualquer indice de reposiçăo ou aumento real, ainda que o secretário afirme que há interesse do prefeito qué isto ocoma.

\section{AMOSENTADOS E READAPTADOS}

Não foi apresentada nenhuma proposta que contemple os aposentados e readaptados como a extensão das gratificações e incorporação aos padröes de vencimentos, restabelecendo. assim, a isonomia.

\section{MFORME SOBRE A SEGUWD REULIO

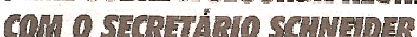

A segunda reunião com o secretário de Educaçăo sobre a REESTRUTURACÃO ocorreu no dia 17 de setembro. A reunião foi marcada horas antes da minifestação que realizamos no dia 14, quando aprovamos a GREVE da categoria a partir do próximo dia 25

Novamente, em vez de entregar a cópia da íntegra do projeto de lei, o secretário e sua assessoria se restringiram a esclarecer o que haviam apresentado e algumas alteraçós que realizaram na proposta inicial.

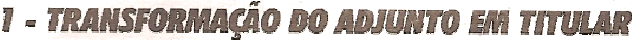

Todos os professores adjuntos transformados em tifular PI ou P II passarăo a ter lotaçäo na unidade escolar. 


\section{ANEXO B \\ Entrevista semi-estruturada feita ao coordenador pedagógico}

\section{Questões iniciais, mais amplas.}

1.Fale um pouco de si mesma, como você descreveria sua vida profissional? (seu processo de escolha profissional, tempo no magistério, tempo na coordenação, sua formação, sua opção pela coordenação.)

2.Como foi o seu início na carreira?

3.O que você incluiria na formação inicial do coordenador pedagógico?

4.O que você acredita ser o papel do coordenador pedagógico na escola?

\section{Questões focalizadoras}

4. Como se dá a formação contínua do docente na escola?

5. O Projeto Especial de Ação (PEA) está voltado para a formação contínua de professores? Como ele é elaborado? Quais os aspectos são considerados visando a sua aprovação?

6. Como você considera/organiza as demandas dos docentes na elaboração do PEA?

7. Qual o papel do coordenador na formação contínua do docente?

8. O que interfere no trabalho de formação contínua que você desenvolve?

9. Qual o sentido da atuação do CP como formador na escola pública?

10. Qual o papel das políticas públicas na formação contínua do docente na escola?

11. O que você entende por cultura escolar?

12. A cultura escolar interfere na condução dos trabalhos de formação na escola? 


\author{
ANEXO C \\ Quadros de observação dos horários coletivos nas Escolas A e B
}

ESCOLA A

\begin{tabular}{|c|c|}
\hline DATA & ASPECTOS OBSERVADOS \\
\hline $29 / 08 / 06$ & $\begin{array}{l}\text { A CP propõe a discussão sobre escrita, mas o grupo coloca a necessidade de } \\
\text { tabular os dados referentes à olimpíada de matemática. A agenda do dia é } \\
\text { reprogramada, os professores começam com a tabulação e, a medida que os resultados } \\
\text { vão aparecendo, os professores preveem intervenções para melhorar o desempenho dos } \\
\text { alunos. } \\
\text { Durante o encontro o CP: } \\
\text { 5. Procura promover a discussão no grupo, sempre relacionando-a com a prática; } \\
\text { 6. Expõe sua opinião; } \\
\text { 7. Procura estabelecer combinados com os professores. } \\
\text { O grupo interrompe alguns minutos a reflexão para um cafezinho (momento de } \\
\text { conversa informal) nesses momentos o clima é mais descontraído, o grupo, ao invés de } \\
\text { se desintegrar, permanece junto. } \\
\text { A CP retoma o projeto de leitura e associa-o ao "Programa Ler e Escrever", o enfoque } \\
\text { está no planejamento do conteúdo das aulas; segundo a coordenadora, a proposta é } \\
\text { mudar a aula. O grupo então planejaria o conteúdo a ser desenvolvido, aplicaria com os } \\
\text { alunos e o resultado desse trabalho seria tema de discussão no grupo. O plano de aula } \\
\text { seguiria as orientações prescritas no documento referencial de leitura e escrita. } \\
\text { A CP solicitou ao grupo que examinasse o material antes de fazer críticas; o grupo } \\
\text { aceitou conhecer o material. }\end{array}$ \\
\hline $12 /$ & $\begin{array}{l}\text { Atividade do encontro: responder em dupla um questionário sobre o trabalho com } \\
\text { leitura e escrita, após estudo do 'Referencial de expectativas para o } \\
\text { desenvolvimento da competência leitora e escritora no ciclo II do ensino } \\
\text { fundamental' } \\
\text { No início, a CP explicou a atividade fazendo referência ao material institucional } \\
\text { (Referencial); } \\
\text { A cada fala dos participantes, corresponde uma fala da CP, que lê os critérios de leitura } \\
\text { expostos no referencial, ouve as perguntas e completa as respostas, e, também, explica } \\
\text { as expressões menos conhecidas relacionadas e que estavam dificultando a } \\
\text { compreensão da atividade, tais como pistas lingüísticas e leitor virtual. } \\
\text { Após o termino dessa atividade, a CP apresentou um vídeo sobre uma sequência } \\
\text { didática. Na análise forma levantados os seguintes pontos: } \\
\text { •O professor é o informante na sala de aula; } \\
\text { • A luta pela alfabetização de todas as pessoas é histórica, o que muda é o processo; } \\
\text { •Se tudo estivesse dando certo, não precisaríamos mudar; } \\
\text { •Na educação, uns tentam convencer o outro; } \\
\text { • A indignação é o que nos dá esperança, mas temos que insistir para encontrar o } \\
\text { caminho. } \\
\text { Proposta - elaborar uma seqüência didática que será aplicada ao aluno e depois } \\
\text { compartilhada no grupo. }\end{array}$ \\
\hline
\end{tabular}




\begin{tabular}{|c|c|}
\hline & $\begin{array}{l}\text { A CP orienta as duplas a fazer a atividade, passa em cada dupla discutindo as dúvidas e } \\
\text { depois dá outras orientações. } \\
\text { Os professores trabalham em duplas, "parecem" concentrados. } \\
\text { À medida que os professores apresentam seus planos, a coordenadora faz intervenções } \\
\text { verbais, buscando acrescentar aspectos não considerados. }\end{array}$ \\
\hline $19 / 0$ & $\begin{array}{l}\text { Atividade do encontro: organização de um seminário interno para a discussão } \\
\text { sobre indisciplina e metodologia. } \\
\text { A CP entende que abrir espaço para a organização do seminário propicia a organização } \\
\text { de ações pedagógicas coletivas. Enfatiza que o aluno é do professor e da escola; "antes } \\
\text { tínhamos propostas, hoje estamos perdidos; a imposição do governo quebrou tudo", } \\
\text { disse a CP. A discussão caminha no sentido de pensar qual o projeto da escola, } \\
\text { acreditava-se que os profissionais tinham que ter claro esse projeto. } \\
\text { A CP distribui uma pesquisa a ser realizada com todos os segmentos da escola: um } \\
\text { questionário para os alunos e entrevistas com funcionários. } \\
\text { Os professores participam da discussão com entusiasmo. Apontam a necessidade de } \\
\text { deixar claro o que a escola pensa. } \\
\text { Na segunda parte da reunião retoma a sequência didática, orientação para quem não } \\
\text { compareceu no último encontro. A CP entregou a planilha para o professor planejar a } \\
\text { sequiência. Continua a questioná-los com perguntas: Qual é o seu objetivo da atividade? } \\
\text { Qual o sentido desse trabalho? } \\
\text { As duplas se apresentam no coletivo e a CP vai interferindo nas apresentações } \\
\text { ampliando alguns aspectos. Quando um professor faz menção ao livro didático, } \\
\text { questiona esse material, o uso que se faz dele e o plano do professor. } \\
\text { Segundo a CP, as atividades têm que ter significado para o aluno. }\end{array}$ \\
\hline $26 /$ & $\begin{array}{l}\text { Atividade do encontro: avaliação e análise de sequência didática } \\
\text { Os professores foram orientados a relatar como foi a aplicação da sequência de } \\
\text { atividade; a CP observava se os passos foram seguidos: ANTES - levantamento do } \\
\text { conhecimento prévio, expectativas dos alunos, antecipação do tema, definição dos } \\
\text { objetivos, DURANTE - confirmação ou retificação das antecipações, conhecimento do } \\
\text { vocabulário e DEPOIS - construção de uma síntese, troca de impressões, avaliação. } \\
\text { Apresentaram suas sequências os professores de geografia que avaliaram que os alunos } \\
\text { participaram mais que o normal; o professor de matemática e a professora de } \\
\text { informática disseram que a participação dos alunos é sempre muito boa nesse tipo de } \\
\text { atividade. } \\
\text { A avaliação foi positiva. } \\
\text { A CP solicita que os professores relacionem a última participação em curso vinculada à } \\
\text { atividade profissional; os professores preenchem o formulário e não questionam o } \\
\text { motivo dessa indagação.Chama a atenção para a formação, para a importância da JEI, } \\
\text { mas, também, para a necessidade de outras instâncias formativas. }\end{array}$ \\
\hline $03 / 10 / 06$ & $\begin{array}{l}\text { Atividade do encontro: continuação da organização do seminário, análise de } \\
\text { textos para a reflexão. } \\
\text { A CP deu continuidade à discussão sobre o seminário, distribuiu material de leitura que } \\
\text { abordava os temas mais solicitados. A proposta era a leitura desse material e a } \\
\text { organização de considerações e síntese. A CP acompanha o trabalho das duplas e } \\
\text { prepara um formulário com o objetivo de organizar o registro dessa leitura. Cada dupla } \\
\text { fez a apresentação das suas considerações e síntese. } \\
\text { A CP traz as contribuições de outros grupos da escola para essa discussão e procura }\end{array}$ \\
\hline
\end{tabular}




\begin{tabular}{|c|c|}
\hline & $\begin{array}{l}\text { aquecer a discussão chamando para o tema. Os grupos foram lendo suas sínteses sem } \\
\text { comentários das outras duplas. Num determinado momento o grupo começa a fazer } \\
\text { uma relação entre aquela leitura e a realidade da escola pública. } \\
\text { A CP procura levar os professores a pensar sobre princípios que considerem a } \\
\text { organização escolar e a indisciplina dos alunos na escola. } \\
\text { Os professores são incentivados a dar sua opinião: dos } 12 \text { presentes, apenas } 5 \text { falam. } \\
\text { A CP vai sintetizando os princípios: } \\
\text { 8. O planejamento das aulas deve considerar diversas metodologias, contribuindo com } \\
\text { a disciplina dos alunos; } \\
\text { 9. A organização da escola deve propiciar condições para viabilizar o processo ensino- } \\
\text { aprendizagem. }\end{array}$ \\
\hline & Atividade durante o dia - não foi possível comparecer. \\
\hline $17 / 10 / 06$ & $\begin{array}{l}\text { Atividade do encontro: socialização dos resultado do seminário, retomada do } \\
\text { 'Referencial'. } \\
\text { A CP comenta sobre o seminário realizado: } \\
\text { • Os princípios elencados serão aplicados no ano seguinte; } \\
\text { - Se a escola quer integrar as famílias, precisa envolver os pais, numa linguagem } \\
\text { acessível; } \\
\text { •Os pais fazem críticas à escola; segundo eles, antes os alunos liam mais; } \\
\text { •Um professor comenta que alguns pais deveriam compor as comissões de } \\
\text { implementação dos princípios; } \\
\text { •A coordenadora comenta que é difícil ter pais na comissão. } \\
\text { Após esta síntese o grupo retoma a sequência didática: } \\
\text { A CP lê as habilidades de leitura descritas no "Referencial"; } \\
\text { Ouve os professores sobre o porquê do uso de textos jornalísticos; } \\
\text { Explica sobre como criar expectativa no aluno. }\end{array}$ \\
\hline $24 / 10 / 06$ & $\begin{array}{l}\text { Atividade do encontro: avaliação e análise de sequência didática } \\
\text { A reunião inicia-se com a fala da CP que diz: "a gente tem que pensar num processo } \\
\text { maior de formação do aluno leitor, projetos de leitura devem ser propostos para } 7^{\mathrm{a}} \text { e } \\
8 \text { a". Esclarece que o seminário realizado foi idéia do grupo de professores e não } \\
\text { solicitação de nenhum curso oferecido para equipe técnica. } \\
\text { A CP organiza com os professores a reunião de pais; abre espaço para comentários } \\
\text { sobre o congresso organizado pelo sindicato dos professores, SINPEEM; diz que as } \\
\text { pessoas estão "despolitizadas". } \\
\text { Agrupa os professores em duplas para a elaboração da sequência didática que seráa } \\
\text { aplicada ao próprio grupo, acompanha as duplas e o desenvolvimento da atividade, } \\
\text { explica que a proposta é, após a apresentação de cada colega, fazer a crítica ao } \\
\text { apresentado partindo das orientações do referencial. }\end{array}$ \\
\hline $31 / 10 / 06$ & $\begin{array}{l}\text { Atividade do encontro: análise de uma sequência didática apresentada pelos } \\
\text { professores. } \\
\text { A CP acompanha toda apresentação do professor com opiniões ou manifestações } \\
\text { gestuais, balançando a cabeça concordando, fazendo sons e anotações durante a fala do } \\
\text { professor que se apresenta, intervém em algumas discussões do tema proposto; } \\
\text { A CP propõe a avaliação da atividade a partir do referencial - destacando depois da } \\
\text { leitura a importância de construir síntese semântica, trocar impressões, registro escrito, } \\
\text { avaliação crítica do texto. A proposta é aplicar a sequiência, adequando-a aos conteúdos } \\
\text { de cada disciplina. Durante a leitura: confirmação das antecipações, localização do }\end{array}$ \\
\hline
\end{tabular}




\begin{tabular}{|c|c|}
\hline & $\begin{array}{l}\text { tema, inferências, identificação das palavras-chave, pistas linguísticas. Antes da leitura } \\
\text { os professores são orientados a testar o conhecimento prévio dos alunos, em função do } \\
\text { suporte, em relação aos autores, definindo o objetivo da leitura. } \\
\text { A CP retoma a fala do professor e sintetiza o objetivo da atividade. } \\
\text { Diante do receio dos professores em relação à avaliação de suas apresentações, } \\
\text { esclarece que a intenção da dinâmica é aplicar os conceitos expostos no referencial - } \\
\text { "Não temos que ter pré-conceitos. Esse trabalho é uma construção. O objetivo é treinar } \\
\text { a sequência didática, e não avaliar". } \\
\text { A CP avalia que em relação a sequências há aspectos que o grupo já domina, como o } \\
\text { levantamento do conhecimento prévio, mas existem outros que precisam ser } \\
\text { melhorados. } \\
\text { No curso (para o CP) foi apontado que os números apresentados nos diagnósticos não } \\
\text { refletem a realidade. "Esse ano foi falho, mas para o ano que vem podemos melhorar. O } \\
\text { referencial apresenta uma multiplicidade de textos que podem ser trabalhados". }\end{array}$ \\
\hline $07 / 11 / 06$ & $\begin{array}{l}\text { Atividade do encontro: análise de uma sequência didática apresentada por um } \\
\text { grupo de professores. } \\
\text { Apresentação de uma sequência organizada por um grupo de professores. Os } \\
\text { participantes, na condição de alunos, analisam uma figura. O QUE SERIA? Depois } \\
\text { leem o texto: O morro doce no nome. } \\
\text { A CP questiona os professores sobre as possibilidades do texto, sugere explorá-lo mais, } \\
\text { conduz os professores para a procura de algumas palavras no dicionário. } \\
\text { A professora explica como desenvolveria a seqüência, o foco estaria em outro texto. } \\
\text { A CP procura ampliar a compreensão sobre a sequência apresentada, relacionando-a } \\
\text { com o "Referencial"; } \\
\text { A CP explora a atividade desenvolvida pela professora, o objetivo da professora era } \\
\text { trabalhar uma receita do pão, indica o referencial como diretriz para pensar os textos } \\
\text { complementares. }\end{array}$ \\
\hline $13 / 11 / 06$ & $\begin{array}{l}\text { Atividade do encontro: análise de uma sequência didática apresentada pelos } \\
\text { professores } \\
\text { Leitura de texto selecionada pelos professores. } \\
\text { Dinâmica organizada pelos professores: colocar em uma bexiga uma curta mensagem } \\
\text { que gostaria de receber e jogar para cima para que outro a pegue. } \\
\text { A CP participa da atividade, recebe elogios dos professores (a CP sabe dizer o que quer } \\
\text { sem ofender); } \\
\text { A CP comenta: "é importante ouvir coisas boas das pessoas, nós temos que enxergar } \\
\text { coisas boas em nós mesmos. A forma como olhamos interfere nas nossas ações. A } \\
\text { escola tem um poder sobre a autoestima dos alunos, o que falamos fica gravado." } \\
\text { A CP propõe analisar a sequência apresentada à luz do referencial, foram lendo trechos } \\
\text { do referencial como critério para a avaliação. } \\
\text { A CP questiona: Os objetivos foram atendidos? Houve a participação de todos? }\end{array}$ \\
\hline $21 / 11 / 06$ & $\begin{array}{l}\text { Atividade do encontro: análise de uma sequência didática apresentada pela } \\
\text { coordenadora. } \\
\text { A CP abre discutindo com o grupo as diferenças entre o13 de maio e o } 20 \text { de } \\
\text { novembro e depois oferece um texto jornalístico para a leitura em dupla. } \\
\text { A CP explica sobre o gênero do texto; anima o grupo a discutir o tema, fatores externos } \\
\text { à libertação dos escravos; explica sobre Zumbi e o movimento de resistência; organiza } \\
\text { a discussão; retoma a palavra e explica sobre as danças e cultura afrobrasileira; solicita }\end{array}$ \\
\hline
\end{tabular}




\begin{tabular}{|c|c|}
\hline & $\begin{array}{l}\text { busca no dicionário das palavras racismo, preconceito e discriminação; solicita uma } \\
\text { ase que sintetiza o texto; apresenta outro texto complementar. }\end{array}$ \\
\hline 28/11/06 & 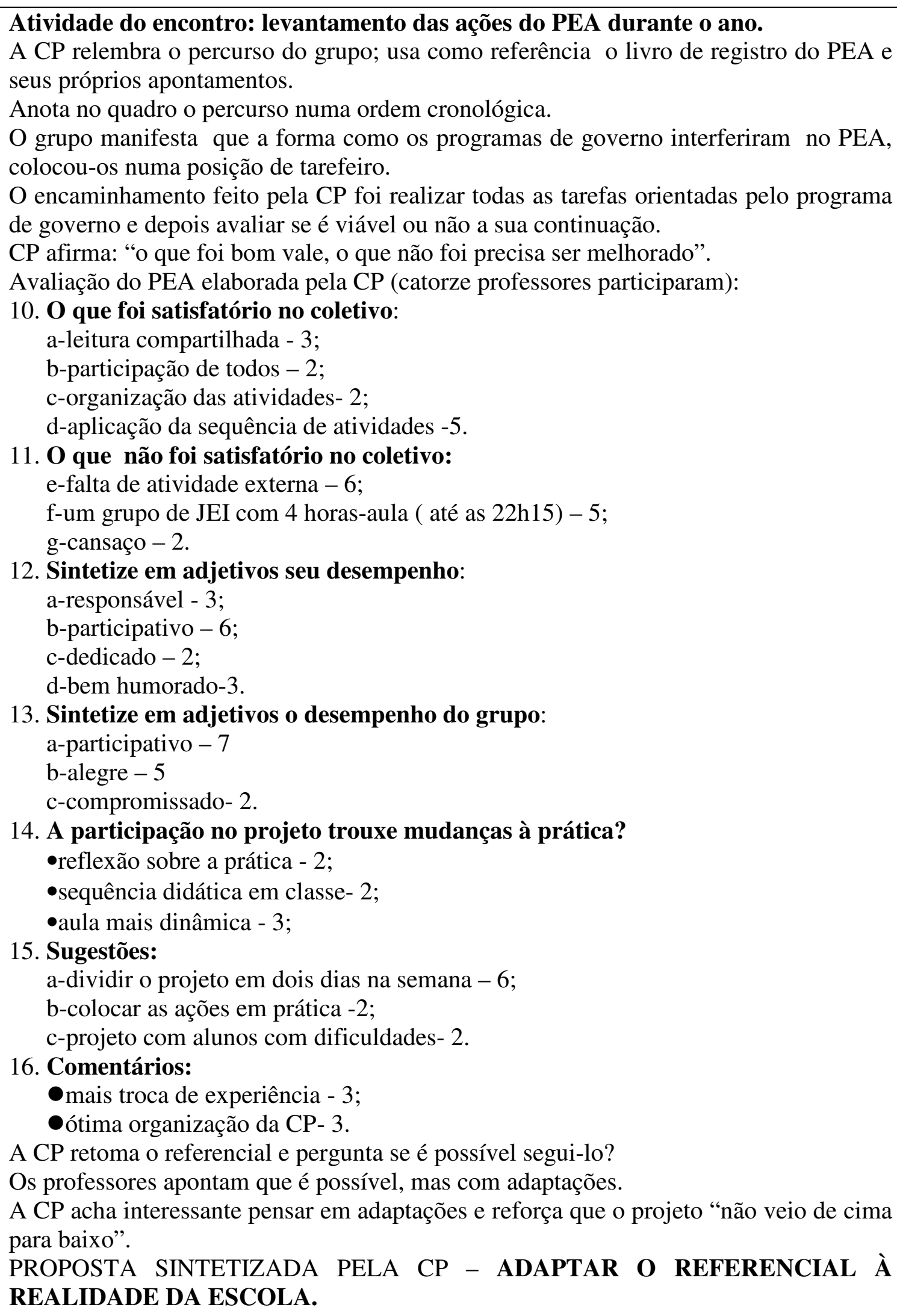 \\
\hline 03/04/0/ & jre a mportancia ua sequencra uiatica. \\
\hline
\end{tabular}




\begin{tabular}{|l|l|}
\hline & $\begin{array}{l}\text { A CP teceu comentários sobre uma reportagem que relatava a prática de um dos } \\
\text { professores do grupo; o professor se sentiu valorizado e o grupo também. } \\
\text { Retomada da sequência em dupla; segundo a CP, quando os professores conversam nas } \\
\text { duplas, todos participam; do contrário, só alguns falam. } \\
\text { CP organiza a pauta ouvindo todos, apresenta a sequência didática explicando cada } \\
\text { quadro. O programa da prefeitura é para ser trabalhado com os alunos. } \\
\text { Segundo a CP, a proposta é aplicar a sequência e discutir as dificuldades no grupo; } \\
\text { informa que cada professor vai receber um caderno de orientação didática por } \\
\text { disciplina. }\end{array}$ \\
\hline $17 / 04 / 07$ & $\begin{array}{l}\text { Atividade do encontro: relato de prática de sequências didáticas. } \\
\text { Os professores procuram levantar o conhecimento prévio do grupo sobre o quadrado } \\
\text { mágico (disciplina matemática). De acordo com a CP a atividade deve colocar o aluno } \\
\text { em situação de reflexão, envolvido com a proposta de atividade. } \\
\text { Inicia-se uma conversa sobre disciplina e indisciplina; a CP lembra da importância do } \\
\text { contrato didático. } \\
\text { Os Professores querem discutir o recreio dirigido que, segundo eles, foi imposto pelo } \\
\text { diretor. } \\
\text { A CP propõe unificar, na JEI, o contrato didático. }\end{array}$ \\
\hline $24 / 04 / 07$ & $\begin{array}{l}\text { Atividade do encontro: discussão sobre indisciplina } \\
\text { Proposta da CP é a unificação do contrato didático discutido por professores e alunos e } \\
\text { criar um regulamento com itens levantados por alunos e professores e discutido por } \\
\text { todos. }\end{array}$ \\
$\begin{array}{l}\text { Atividade do encontro: análise da reunião de pais, informes e apresentação das } \\
\text { sequências organizadas. } \\
\text { A CP sugere que cada grupo apresente a sequência planejada na JEI para os } \\
\text { comentários do grupo e depois ela acompanharia cada professor na aplicação em sala } \\
\text { de aula. O objetivo era analisar com o professor o que deu certo e o que não deu. } \\
\text { No curso de CP, levantaram a possibilidade de, no caso de o coordenador não puder } \\
\text { acompanhar o professor em sala de aula, o diretor fazê-lo. }\end{array}$ \\
\hline $08 / 05 / 07$
\end{tabular}




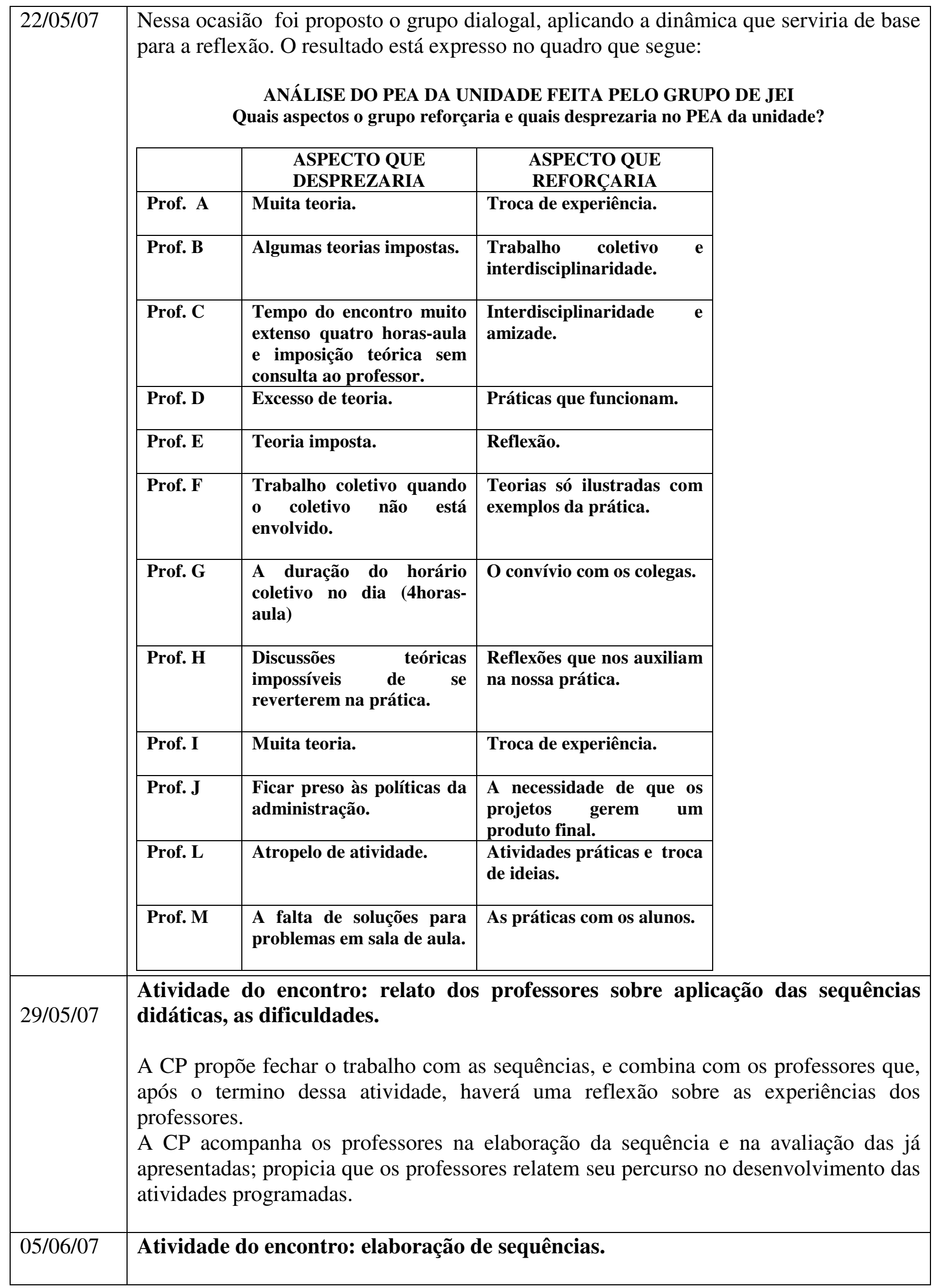




\begin{tabular}{|l|l|}
\hline \multirow{1}{*}{$19 / 06 / 07$} & $\begin{array}{l}\text { A CP acompanha cada grupo na elaboração da sequência, orienta a apresentação da } \\
\text { leitura feita sobre os cadernos de orientação por áreas de ensino e questiona: Por quais } \\
\text { experiências todos os alunos têm que passar para que eles desenvolvam o hábito de } \\
\text { leitura? Comenta como os professores do Ciclo I trabalham com os gêneros literários. }\end{array}$ \\
$\begin{array}{l}\text { Atividade do encontro: avaliação do semestre } \\
\text { O grupo questiona sobre a diferença entre uma sequência didática e outro tipo de plano. } \\
\text { Para o segundo semestre a coordenadora propõe alternar a formação do "Ler e } \\
\text { Escrever" considerando as ideias do grupo sobre o ensino da leitura e escrita em todas } \\
\text { as áreas. } \\
\text { Um professor sugere que caso não haja outra proposta o grupo poderia continuar com } \\
\text { as mesmas atividades. }\end{array}$ \\
\hline
\end{tabular}

\section{ESCOLA B}

\begin{tabular}{|c|c|}
\hline Data & Comentários \\
\hline $31 / 08 / 06$ & $\begin{array}{l}\text { Atividade do encontro: discussão sobre avaliação } \\
\text { Segundo a CP, existe a necessidade de melhorar os registros avaliativos das crianças. } \\
\text { A CP acompanha o grupo, comenta as falas, reconduz o grupo à discussão inicial, } \\
\text { enfatiza que, por trás da avaliação e seu registro, existe uma concepção de educação. } \\
\text { Os diagnósticos sistemáticos e os registros das observações cotidianas são importantes. } \\
\text { A CP orienta que todos precisam tomar cuidado para não avaliar uma criança em } \\
\text { relação à outra criança, mas como iniciaram e como terminaram. (essas intervenções } \\
\text { são mediadas pelas falas dos professores que participam bastante). } \\
\text { Os professores comentam sobre os cantos de atividades, organização do espaço após a } \\
\text { formação oferecida ao CP por meio do instituto Avisa-lá (participar dessa formação foi } \\
\text { opção da escola). } \\
\text { Os professores comentaram as dificuldades com o rodízio de salas (salas ambientes). } \\
\text { A CP comenta que a formação do Instituto não considera a realidade e, portanto, a } \\
\text { escola deverá fazer adaptações e retomar a discussão sobre avaliação afirmando que o } \\
\text { vídeo é um instrumento de registro que pode auxiliar na reflexão sobre a prática. } \\
\text { Em seguida passa a questionar os professores para que repensem suas formas de } \\
\text { registros avaliativos. }\end{array}$ \\
\hline $21 / 09 / 06$ & $\begin{array}{l}\text { Atividade do encontro: análise de vídeo que apresenta trabalho com os cantos } \\
\text { diversificados } \\
\text { A CP apresenta um vídeo pedagógico e informa que o Instituto Avisa-lá fez formação } \\
\text { com a creche retratada no vídeo. Solicita que observem: brinquedos, parque, cabanas } \\
\text { etc. Levanta questões: Como foi a interação entre as crianças? O que foi bom? O que } \\
\text { foi interessante observar? Como foram organizadas as crianças? Como aconteciam as } \\
\text { atividades? Qual a diferença entre esse parque e o daquela unidade? O que os } \\
\text { professores fizeram antes? (Planejaram?) Qual o desafio das crianças no parque? } \\
\text { Os professores, durante o encontro, vão comentando suas próprias dificuldades: as salas } \\
\text { indisciplinadas; as crianças muito agitadas. } \\
\text { A CP orienta, começar o trabalho com os cantos de atividades direcionando o trabalho, } \\
\text { ou seja, indicando os cantos em que as crianças devem passar, depois deixar mais livre, } \\
\text { ressalta que devem começar com poucos cantos, adaptá-los a realidade da escola. } \\
\text { Busca a participação do grupo. Pergunta: "Quem quer falar?" Ninguém se manifesta. }\end{array}$ \\
\hline
\end{tabular}




\begin{tabular}{|c|c|}
\hline 05/10/06 & $\begin{array}{l}\text { Atividade do encontro: leitura e reflexão sobre o trabalho com os cantos } \\
\text { diversificados. } \\
\text { O texto oferecido para a leitura foi o mesmo utilizado no curso ministrado pelas } \\
\text { formadoras do Instituto Avisa-lá; as ideias desse curso, segundo a } \mathrm{CP} \text {, condiz com a } \\
\text { concepção pedagógica da escola. } \\
\text { As professoras traziam suas experiências durante a leitura ora como contraponto, ora } \\
\text { como apoio as idéias do texto, a reflexão sobre brincadeiras retomou a discussão sobre } \\
\text { avaliação. } \\
\text { As professoras avaliam que muito do que o texto apresenta, já é uma prática na escola. } \\
\text { A CP orienta para a necessidade de organizar a semana da criança. Sugere o trabalho } \\
\text { com circuito de brincadeiras que está relacionado a cantos diversificados. Nesse } \\
\text { momento os professores são deixados mais livres para planejar. }\end{array}$ \\
\hline 19/10/06 & $\begin{array}{l}\text { Atividade do encontro: leitura e reflexão sobre o trabalho com os cantos } \\
\text { diversificados - continuação. } \\
\text { A CP inicia o encontro apontando a necessidade da mobilidade dos cantos de atividade } \\
\text { na sala de aula e da interação das crianças. Informa que parte do material necessário } \\
\text { para essa organização havia sido comprado com a verba recebida. } \\
\text { Alguns cantos são sugeridos: canto da história, canto das artes visuais. } \\
\text { Os professores encaminham a discussão para organização da sala de artes. } \\
\text { A CP lembra que a brinquedoteca melhorou a sua organização em função dos cantos de } \\
\text { brincadeiras. } \\
\text { Continuação da leitura do texto. }\end{array}$ \\
\hline $14 / 03 / 07$ & $\begin{array}{l}\text { Atividade do encontro: reflexão sobre os avanços das crianças no período de } \\
\text { adaptação. } \\
\text { A CP enfatiza que nessa confraternização a ênfase está no compartilhar. } \\
\text { Os Professores e CP passam a organizar a atividade considerando o sentido dado a } \\
\text { festa, o partilhar. } \\
\text { A CP sugere brincadeiras que desafiem a criança. Professores sugerem um painel de } \\
\text { mensagem sobre a páscoa. } \\
\text { A CP, na segunda parte do encontro, solicita das professoras um registro sobre o } \\
\text { período de adaptação. } \\
\text { Iniciam uma discussão sobre as diferenças entre os alunos que já eram da escola e as } \\
\text { crianças novas. Pensam sobre encaminhamentos para as turmas novas. }\end{array}$ \\
\hline $21 / 03 / 07$ & $\begin{array}{l}\text { Atividade do encontro: organização das caixas de leitura para o projeto "historias } \\
\text { de bruxas". } \\
\text { A CP retoma os conceitos: ler historias e contar historias (tradição oral). Os professores } \\
\text { pesquisam livros de literatura infantil para desenvolver o "Projeto ler histórias de } \\
\text { bruxa". Ler histórias é uma atividade permanente. } \\
\text { A CP solicita a participação das professoras pedindo relatos sobre experiências de } \\
\text { leitura de anos anteriores. } \\
\text { A experiência docente possibilita afirmar que as crianças repetem as histórias contadas } \\
\text { pelos professores em casa e para outros amiguinhos. } \\
\text { Os Professores sugerem que os livros dos projetos não fiquem nas caixas e que se } \\
\text { organize um controle dos livros emprestados. A CP acolhe as sugestões. }\end{array}$ \\
\hline 28/03/07 & ide do encontro: análise das fichas de ava \\
\hline
\end{tabular}




\begin{tabular}{|c|c|}
\hline & $\begin{array}{l}\text { Os professores aproveitaram essa reunião para socializar atividades referentes à páscoa, } \\
\text { para organizar o painel de mensagem que será usado pelos pais, que deixarão suas } \\
\text { mensagens para os filhos e para a comunidade. } \\
\text { Também, analisaram as fichas de avaliação que receberam da professora do ano } \\
\text { anterior. }\end{array}$ \\
\hline $11 / 04 / 07$ & $\begin{array}{l}\text { Atividade do encontro: reflexão sobre o relatório de avaliação do período de } \\
\text { adaptação. } \\
\text { Neste dia, a CP retoma uma atividade iniciada em outro encontro que foi a escrita de } \\
\text { relatórios sobre o período de adaptação. Cada professor leu o seu relatório. A maioria } \\
\text { enfatizava o grande número de alunos por turma (35), a falta de limite das crianças, a } \\
\text { demora para adaptação à rotina da escola. } \\
\text { A CP chama a atenção para os encaminhamentos a partir do relatório: se a criança não } \\
\text { tem repertório de história, de desenho, de animais, de figura humana .... o que fazer? } \\
\text { A CP orienta que os bons registro revelam os encaminhamentos docentes. } \\
\text { Outros relatórios enfatizaram a apatia de algumas crianças, a falta de contato com a } \\
\text { linguagem escrita, a curiosidade das crianças em relação à sexualidade. } \\
\text { A CP questiona: Quais as decisões a partir do registro? Quais os encaminhamentos } \\
\text { sobre a prática? O registro para a criança também é difícil. O professor que registra é } \\
\text { mais crítico em relação a sua prática. Enfatiza que todo conhecimento construído deve } \\
\text { voltar-se para a prática do professor. O registro, segundo a CP, revela o conhecimento } \\
\text { que se constrói. } \\
\text { A CP solicita que após esse exercício os professores deverão escrever outro texto } \\
\text { apontando os encaminhamentos a partir dessa reflexão. }\end{array}$ \\
\hline $18 / 04 / 07$ & $\begin{array}{l}\text { Atividade do encontro: discussão sobre brincadeiras infantis } \\
\text { A CP inicia o encontro apresentando como ponto de pauta as brincadeiras infantis. } \\
\text { Os Professores relatam que sentem as crianças (de modo geral) presas, escolas } \\
\text { particulares não trabalham com as brincadeiras, interagem com outros pares que não } \\
\text { tem memória de brincadeiras coletivas, de rua etc } \\
\text { A CP enfatiza a importância do brincar na educação infantil. } \\
\text { A CP orienta ensinar as brincadeiras tradicionais que repetem nomes diferentes em } \\
\text { diferentes lugares; as brincadeiras ajudavam as crianças a resolver problemas e a } \\
\text { construir regras. Hoje a escola ensina a brincar, mas no passado as brincadeiras eram } \\
\text { ensinadas por uma criança mais velha ou pelos pais; as brincadeiras eram significativas. } \\
\text { As crianças precisam aprender a brincar, é na brincadeira que a gente vai vencer } \\
\text { frustrações, medos, inseguranças, aprender a dividir, a reagir, sempre junto com outras } \\
\text { crianças. A brincadeira possibilita trocar pontos de vistas e experiências. Nas } \\
\text { brincadeiras é possível observar como eles se veem e como são vistos pelos colegas. }\end{array}$ \\
\hline $25 / 04 / 07$ & $\begin{array}{l}\text { Atividade do encontro: discussão sobre paralisação e dia das mães. } \\
\text { Nesse dia a CP abre um espaço para os representantes dos sindicatos que trazem } \\
\text { informações: sobre o concurso para coordenador pedagógico; sobre o piso salarial; } \\
\text { sobre reestruturação da carreira etc. A discussão demonstra a fragilidade do magistério } \\
\text { frente às demandas do governo. } \\
\text { Inicia-se uma conversa sobre o Dia das mães e decidem pelo chá com apresentação } \\
\text { musical nas salas. } \\
\text { Resolvida a questão referente ao dia das mães, os professores continuam a leitura do } \\
\text { texto sobre cantos de atividades e vão relatando as dificuldades, ou seja, manter os } \\
\text { cantos organizados; fazer a intervenção mais adequada; e o fato das crianças } \\
\text { procurarem os cantos que têm familiaridade. A coordenadora orienta que os cantos na }\end{array}$ \\
\hline
\end{tabular}




\begin{tabular}{|l|l|}
\hline & sala não devem ser permanentes. \\
\hline $09 / 05 / 07$ & $\begin{array}{l}\text { Atividade do encontro: brincar na educação infantil } \\
\text { A CP retoma a discussão sobre o brincar na educação infantil. } \\
\text { A CP acredita na proposta do brincar. Ressalta a importância de planejar os cantos; } \\
\text { organizar as salas e o cuidado com o material público. O trabalho com os cantos } \\
\text { pressupõe a organização de um tempo de trabalho para cada faixa etária. } \\
\text { O professor precisa ajudar as crianças a observar os cantos para que eles possam } \\
\text { escolher. }\end{array}$ \\
\hline $16 / 05 / 07$ & $\begin{array}{l}\text { Atividade do encontro: organização das caixas de brinquedos. } \\
\text { Nesse dia, as professoras se concentraram na atividade de organização do material para } \\
\text { as brincadeiras infantis; segundo a CP, a discussão teórica havia sido feita no dia } \\
\text { anterior. }\end{array}$ \\
\hline $23 / 05 / 07$ & $\begin{array}{l}\text { Atividade proposta pela pesquisadora. } \\
\text { Pensar sobre aspecto que reforçariam ou desprezariam no PEA da escola. }\end{array}$ \\
\hline $13 / 06 / 07$ & $\begin{array}{l}\text { Atividade proposta pela pesquisadora. } \\
\text { Como argumentar em favor da JEIF diante da possibilidade de extinção da jornada? }\end{array}$ \\
\hline
\end{tabular}

